Hanne Cecilie Kavli

\title{
Kontinuitet og endring
}

\section{Familiepraksis og kvinners yrkesdeltakelse blant innvandrere i Norge}

Avhandling for Ph.d. graden.

Institutt for sosiologi og samfunnsgeografi.

Det samfunnsvitenskapelige fakultet.

Universitetet i Oslo. 
(C) Hanne Cecilie Kavli, 2020

Doktoravhandlinger forsvart ved

Det samfunnsvitenskapelige fakultet, Universitetet i Oslo.

No. 794

ISSN 1564-3991

Det må ikke kopieres fra denne boka i strid med åndsverkloven eller med avtaler om kopiering inngått med Kopinor, interesseorgan for rettighetshavere til åndsverk.

Omslag: Hanne Baadsgaard Utigard.

Grafisk produksjon: Reprosentralen, Universitetet i Oslo. 


\section{Innhold}

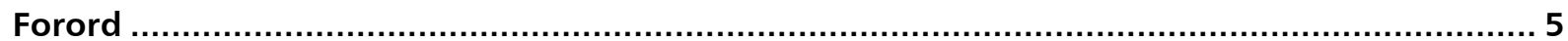

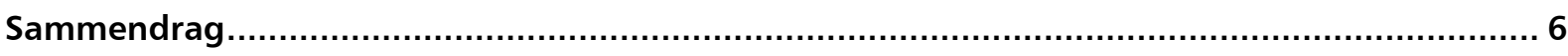

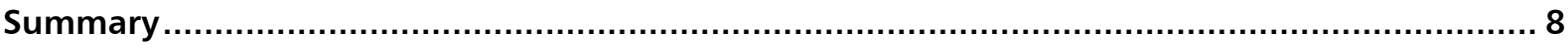

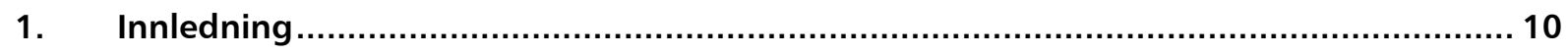

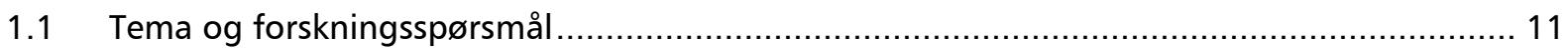

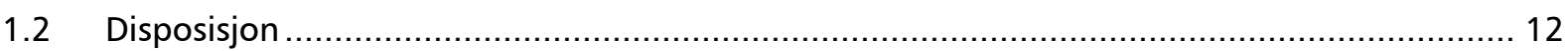

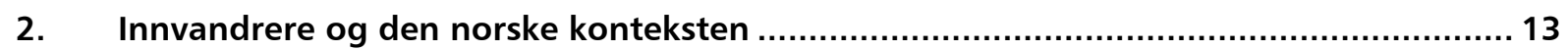

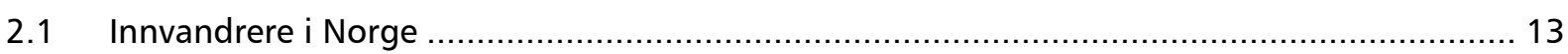

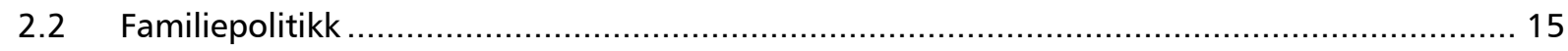

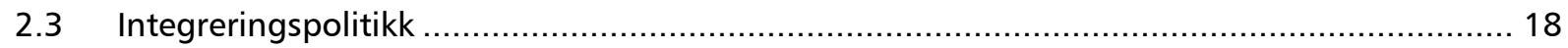

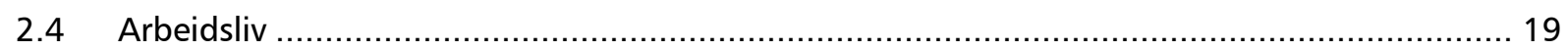

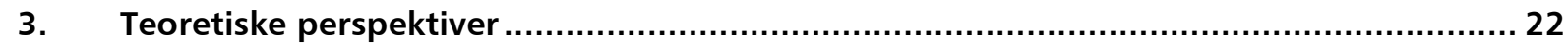

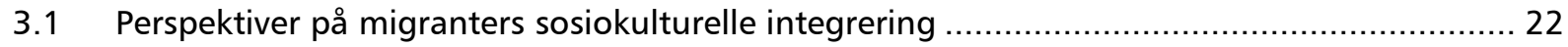

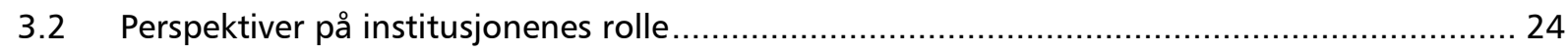

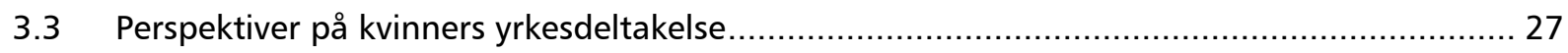

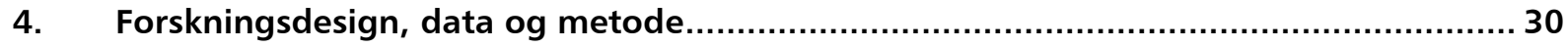

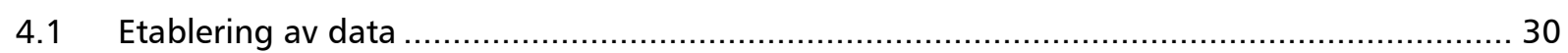

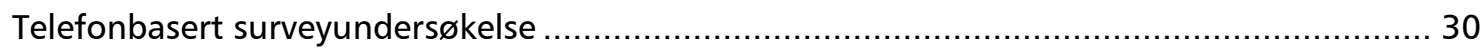

Kvalitative intervjuer og fokusgrupper med byråkrater og brukere...................................... 34

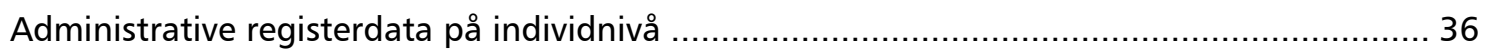

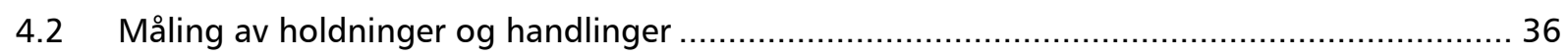

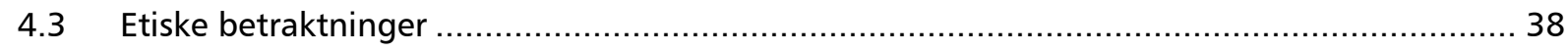

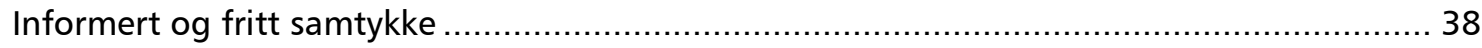

Hensynet til andres livssituasjon, verdier og handlingsmotiver ......................................... 39

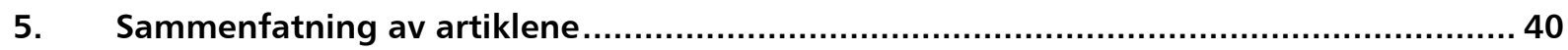

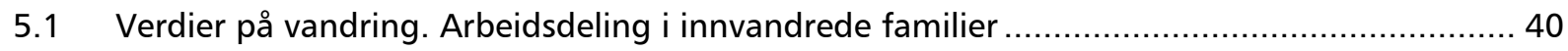

5.2 Integrert eller marginalisert? Innvandrede kvinner i norsk arbeidsliv ................................... 41

5.3 Facilitating user-involvement in activation programs: when Carers and Clerks meet Pawns and

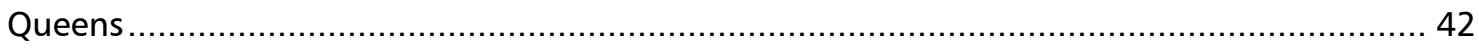

5.4 Adapting to the dual earner model? Attitudes to mothers' employment among immigrants and immigrant descendants in Norway. 


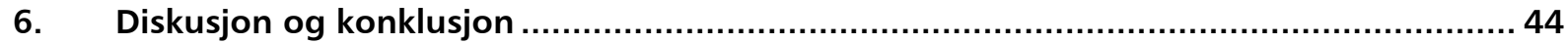

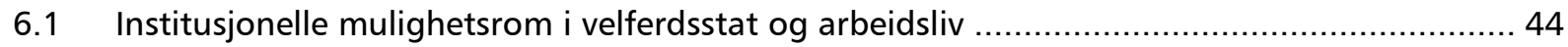

6.2 Institusjonelle møter - mellom nasjonale intensjoner, lokale realiteter og individuelle

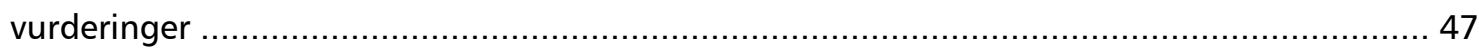

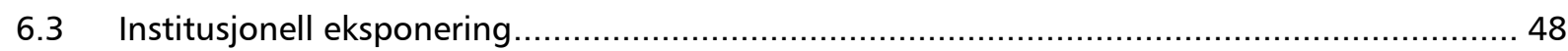

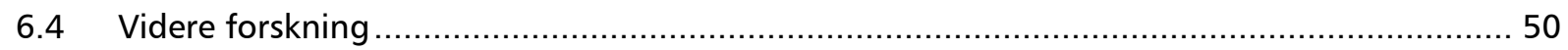

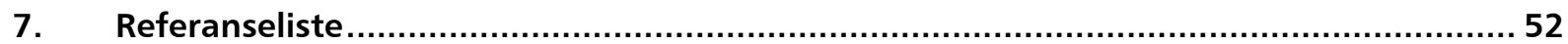

Artikkel 1. Verdier på vandring. Arbeidsdeling i innvandrede familier .................................59

Artikkel 2 Integrert eller marginalisert? Innvandrede kvinner i norsk arbeidsliv ................. 85

Artikkel 3 Facilitating user involvement in activation programmes: When Carers and Clerks

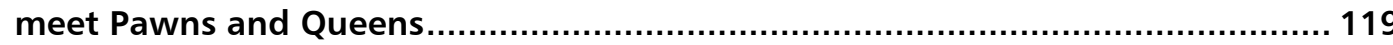

Artikkel 4 Adapting to the dual earner family norm? The case of immigrants and immigrant descendants in Norway............................................................................. 141 


\section{Forord}

Mitt engasjement for integreringsfeltet har, i likhet med avhandlingen, vokst fram gjennom en lang rekke prosjekter ved Fafo. Jeg har lært mye av alle de som har tatt seg tid til å dele sine erfaringer og refleksjoner med meg. Dere er for mange til å nevnes, men finnes både blant byråkrater, norsklærere, frivillige, forskere og ikke minst, blant en lang rekke tidligere flyktninger og innvandrere som har vist meg tillit gjennom å fortelle om sine møter med ulike deler av det norske samfunnet. Uten dere, ingen avhandling.

Skal man komme seg noenlunde helberget gjennom en avhandling er det en fordel med gode veiledere. Jeg har hatt gleden av to av de beste. Anne Lise Ellingsæter og Axel West Pedersen har stilt opp på alle vis. Ikke minst er jeg takknemlig for at de har utvist betydelig tålmodighet hver gang jeg fikk los på et nytt prosjekt som har forsinket arbeidet med avhandlingen. Det har blitt både bok, artikler og rapporter underveis. Tusen takk også til Fafo, som har lagt til rette for jeg kunne få skrive denne avhandlingen. Jeg er heldig og jobber i et engasjert, raust og kompetent faglig miljø. Takk til Tone Fløtten, som hadde troen på at dette skulle gå fint, til MIK'erne, for kommentering av artikler, effektive skrivekontor og heiarop på oppløpssiden, til Kristine Nergaard for tilrettelegging av hårete datafiler og for vennlige «leverings-dult» nå på tampen og til alltid positive og løsningsorienterte Bente Bakken som med stø hånd rydder i rotete manuskripter. Takk også til tidligere kollega Marjan Nadim, som jeg samlet inn surveymaterialet med og som skal ha en stor del av æren for at det ble så bra som det ble.

Og så er det vennene mine, som sørger for at det skjer gøye ting også utenfor arbeidstid. Tusen takk - hver og en av dere. To skal likevel nevnes særlig - Anne Britt Djuve og Heidi Nicolaisen. Begge er medforfattere på hver sin artikkel i avhandlingen og nære venner gjennom mange år. Dere gjør hverdag til fest og arbeid til lek. Bedre blir det ikke!

Sist, men ikke minst - den største takken går til familien min. Håkon, som kjenner meg godt nok til å se når jeg trenger å skrive, når jeg trenger en klem, og når jeg trenger en film, en konsert eller en lang tur på fjellet. Tuva og Anja, som sørger for liv, røre og perspektiv på tilværelsen. Mamma, som har testet spørreskjema og bidratt med egne fortellinger om kvinners hverdagsliv i Fredrikstad på 1940- og 50-tallet. Og Pappa - som vekket min interesse for litteratur og som aldri sluttet å engasjere seg for hvordan samfunnet kunne bli bedre for de som har minst og er mest sårbare. Denne er til deg.

\section{Hanne Cecilie Kavli}

Kolbotn, 2019 


\section{Sammendrag}

I Norge møter innvandrere en samfunnsmodell med en særegen kobling mellom arbeidsliv, familieliv og velferdsstat. De møter også en normativ forventning om at kvinner skal delta i arbeidslivet. Temaet for avhandlingen er hvordan innrettingen av velferdsstat og arbeidsliv kan forme ulike institusjonelle mulighetsrom og gjennom dette påvirke innvandreres holdninger og praksiser rundt organiseringen av familielivet og kvinners lønnsarbeid. Temaet berører sentrale debatter i migrasjonsforskningen, som forholdet mellom innvandreres økonomiske og kulturelle tilpasninger, og samspillet mellom disse tilpasningene og den institusjonelle konteksten $\mathrm{i}$ bostedslandet. Jeg trekker også inn perspektiver fra den mer generelle litteraturen om velferdsstat, arbeid og familie for å belyse hvordan institusjonelle strukturer kan legge rammer for familienes organisering og kvinners yrkesdeltakelse. Avhandlingen bygger på a) en surveyundersøkelse blant 1821 personer fra Iran, Irak, Norge, Pakistan og Vietnam, b) kvalitative intervjuer og fokusgrupper med byråkrater og brukere i introduksjonsprogram for nyankomne flyktninger og innvandrere og c) norske registerdata med informasjon om kvinner i lønnet arbeid fra Iran, Irak, Norge, Pakistan, Somalia og Vietnam.

I artikkel 1 viser jeg at en betydelig andel innvandrere har en mer kjønnslikestilt praksis enn det holdningene deres skulle tilsi. Ifølge neo-assimileringsteori kan vi forstå dette som et uttrykk for en rasjonell tilpasning for å oppnå gode levekår. Dissonansen kan dermed være et resultat av at den norske konteksten skyver familier med kjønnstradisjonelle holdninger i retning av en mer kjønnslikestilt praksis. Samtidig har en betydelig andel innvandrere i mitt materiale kjønnstradisjonelle holdninger og praksiser som sammenfaller. Ved første øyekast framstår denne gruppen som mer robust i møtet med den norske konteksten. En alternativ beskrivelse er at de treffer - og tilpasser seg - andre sider ved de institusjonelle strukturene enn de som lever mer kjønnslikestilt. Hovedsporet i norsk familie- og likestillingspolitikk er tett forbundet med kvinners yrkesdeltakelse. Kvinner utenfor arbeidslivet, og familier med behov for offentlig inntektssikring, møter imidlertid andre ordninger som produserer andre typer av mulighetsrom med andre insentivstrukturer.

Insentivstrukturer og mulighetsrom formes ikke bare av velferdsstatens organisering, men også av innvandreres muligheter i norsk arbeidsliv. I artikkel 2 rettes søkelyset mot innvandrede kvinner i lønnet arbeid, deres mobilitet i arbeidstid og arbeidstilknytning og hva dette kan fortelle om muligheter og begrensinger i norsk arbeidsliv. Blant norske kvinner uten innvandringsbakgrunn er deltid en relativt stabil form for arbeidsmarkedstilknytning. For innvandrede kvinner i de landgruppene jeg har studert, er bildet mer delt og mobiliteten både i arbeidstid og arbeidstilknytning er høyere. Med noen unntak har innvandrede kvinner høyere tilbøyelighet til å øke arbeidstiden sin enn kvinner uten innvandringsbakgrunn. Det tyder på at 
deltid i mindre grad er frivillig. Samtidig har innvandrede kvinner også en høyere risiko for å gå ut av arbeidslivet. Arbeidslivet som møter innvandrede kvinner med lav kompetanse har egenskaper som både kan gjøre det krevende å få innpass og å stå i arbeid over tid. For å belyse innvandrede kvinners økonomiske integrering er det derfor en viktig oppgave å etablere mer kunnskap om innvandrede kvinner som arbeidstakere, ikke bare som mødre og kulturbærere.

En sentral ambisjon i norsk integreringspolitikk er å øke kvinners yrkesdeltakelse og at også mødre skal delta i arbeidsrettet kvalifisering. Bakkebyråkratenes iverksetting av denne politikken kan likevel avvike fra de nasjonale intensjonene. I artikkel 3 er temaet fortsatt hvordan velferdsstatens og arbeidslivets strukturer kan påvirke integreringsprosesser, men nå belyst gjennom interaksjon mellom innvandrere og bakkebyråkrater i velferdsstatens førstelinje. Gjennom å analysere brukermedvirkning innenfor rammen av introduksjonsprogrammet for nyankomne flyktninger og innvandrere, viser vi hvordan ulike typer av bakkebyråkrater kan ha ulik praksis i møte med ulike typer av brukere. Analysen illustrerer Lipskys (1980) poeng om at bakkebyråkrater ikke agerer som rene iverksettere av politikk, men også er med på å utforme politikkens innhold. I noen tilfeller fortolker - eller tøyer - byråkrater regelverket slik at det skal bli lettere å balansere omsorgsarbeid og deltakelse i programmet. Et av artikkelens bidrag er også illustrasjonen av den rollen egenskaper ved deltakerne i programmet, og deres holdninger og preferanser, kan ha i å prege politikkens implementering. For å forstå hvordan velferdsstatens institusjoner former ulike mulighetsrom for ulike grupper av innvandrere kan analysen derfor med fordel omfatte ikke bare formell politikk, men også ulike aktørers rolle i politikkens implementering.

I artikkel 4 undersøker jeg hvilken betydning eksponering for den norske konteksten har for holdninger til mødres yrkesdeltakelse. Et vesentlig spørsmål er om holdningene påvirkes av hvor lenge du har vært eksponert for den norske institusjonelle konteksten, eller om det handler mer om hvem du er og hvordan det er gått med deg i Norge. Innvandrere med gode norskferdigheter og god økonomi er blant de som er mest positive til mødres yrkesdeltakelse. Det kan dermed virke som at innvandrere med gode forutsetninger for å lykkes økonomisk, i større grad også tilpasser seg kulturelt. Alternativt kan denne gruppen av innvandrere allerede før innvandringen ha vært mer positive til mødres yrkesdeltakelse. Innvandreres holdninger til mødres yrkesdeltakelse ser i liten grad ut til å variere med botid i Norge. Betydningen av botid, eller kanskje snarere av å vokse opp i Norge, framstår langt klarere blant etterkommere. Dette føyer seg inn i et mønster der etterkommernes familiepraksiser og holdninger nærmer seg de som dominerer i majoritetsbefolkningen. Samtidig er oppslutningen om mødres yrkesdeltakelse lavere blant pakistanske etterkommere enn blant personer uten innvandringsbakgrunn. Endring kombineres her med kontinuitet. 


\section{Summary}

In Norway, immigrants meet a society with a particular blend of working life, family life and welfare state. They also face a normative expectation of female employment. The topic of this dissertation is how the welfare state and working life shape institutional spaces of opportunity and constraint, and thereby influence immigrants' attitudes and practices in relation to family life and mothers' employment. The topic speaks to major debates in the field of migration studies, like the relationship between immigrants' economic and cultural adaptation, and the interplay between these adaptations and the institutional context in the host country. I also draw on theories from literature on the welfare state, work and family to inform my analysis of how institutional structures can influence immigrants' family lives and women's labour market participation. The thesis is based on a) a survey of 1821 persons from Iran, Iraq, Norway, Pakistan and Vietnam, b) qualitative interviews and focus groups with bureaucrats and users of the Norwegian Introductory Programme for recently arrived refugees and immigrants, and c) Norwegian register data held on women in paid work from Iran, Iraq, Norway, Pakistan, Somalia and Vietnam.

In Article 1, I show that a significant share of immigrants have a more gender-equal practice than that indicated by their attitudes. One way to interpret this dissonance is as a consequence of a rational adaptation to practises that may result in better living conditions. The lack of coherence between attitudes and practises may therefore be a result of the Norwegian context pushing families with gender-traditional attitudes towards a more gender-equal practice. However, a significant share of immigrants in my survey data have gender-traditional attitudes and practices that coincide. At first glance, this group appears to be more robust in its encounter with the Norwegian context. An alternative description is that they face - and adapt to - other aspects of the institutional structures. Norwegian family and gender-equality policy is closely linked to women's labour market participation. Women outside the labour market, and families in need of government-funded income protection, encounter other schemes, which produce other spaces of opportunity, with other incentive structures.

Incentive structures and spaces of opportunity are not only shaped by welfare state and family policy, but also by immigrants' opportunities in Norwegian working life. In the second article, I move the focus to register data, part-time employees and what this can tell us about the opportunities and limitations in working life for immigrant women from the aforementioned countries. Among Norwegian women without an immigrant background, part-time work is a relatively stable form of labour market attachment. For immigrant women, the picture is more complex. With some exceptions, immigrant women in part-time work have a greater tendency to increase their working hours than women without an immigrant background. However, 
immigrant women also have a significantly higher risk of dropping out of the labour market than women without an immigrant background. The labour market conditions that immigrant women with a low level of education face can make it a challenge both to gain entry and to remain in work over time. In order to broaden our understanding of immigrant women's economic integration, it is therefore important that future research generates more knowledge about immigrant women as employees, not just as mothers and culture bearers.

A key ambition of Norwegian integration policy is that mothers should also participate in measures aimed at qualifying them for the labour market. However, the street-level bureaucrats' implementation of this policy may diverge from national intentions. In the third article, the topic is still how the structures of the welfare state and working life can influence integration processes, but the emphasis here is on the interaction between immigrants and street-level bureaucrats in the welfare state's front line. By analysing user involvement in situations where participants on activation programmes either do not express what they want, or have preferences that are not in line with the programme's guidelines, we show how practices can vary between different types of street-level bureaucrats in the encounter with different types of users. The analysis illustrates Lipsky's (1980) point that street-level bureaucrats do not act as mere policy implementers, but also help to shape policy content. One of the article's contributions to research is also, in my view, how it illustrates the role that programme participants' characteristics, attitudes and preferences can play in influencing policy implementation. In order to understand how the welfare state's institutions form different types of spaces of opportunity for different groups of immigrants, the analysis should therefore cast a wider net than the formal institutions.

In the fourth article, I examine how exposure to the Norwegian context impacts on attitudes towards mothers' employment. Are attitudes towards mothers' employment influenced by how long you have been exposed to the Norwegian institutional context, or are attitudes more related to who you are and how you have managed in Norway? Immigrants with good Norwegian language skills and a satisfactory financial situation are among those who are most positive about mothers' labour market participation. It can thus seem that immigrants with a strong foundation to succeed financially are also more likely to adapt culturally. Alternatively, this group of immigrants may have been more inclined to support mothers' labour market participation even before immigration. I find no indication that attitudes towards mothers' employment is related to years of residency in Norway. The relevance of exposure-time, or perhaps rather of growing up in Norway, are more clear for immigrant descendants. Pakistani descendants view mothers' labour market participation in a far more positive light than Pakistani immigrants do. This fits into a pattern in which the descendants' family practices and attitudes are more on a par with those who dominate the majority population. However, support for mothers' labour market participation is lower among Pakistani descendants than among those without an immigrant background. Change is combined with continuity. 


\section{Innledning}

Det norske samfunnet har gått gjennom store endringer de siste 50 årene. En utdanningsrevolusjon har truffet brede lag i befolkningen. Kvinner har strømmet ut i arbeidslivet, godt støttet av en voksende offentlig sektor, og flertallet av kvinner - også mødre jobber i dag heltid. Utviklingen fra en- til to-inntektsfamilier har blitt ledsaget av omfattende sosialpolitiske reformer. Samtidig har samfunnet blitt mer flerkulturelt. I 1970 var 1,5 prosent av landets befolkning innvandrere. I dag har 950000 innbyggere - 17,8 prosent av befolkningen - enten selv innvandret eller er barn av to innvandrere. Debatten om hva dette betyr for samfunnet, har økt i styrke parallelt med at innvandringen har økt i omfang. Kombinasjonen av $ø k t$ innvandring, lav sysselsetting i en del innvandrergrupper og bekymring for velferdsstatens bærekraft har ført spørsmålet om innvandreres økonomiske integrering stadig høyere opp på den politiske dagsorden. Innvandrede kvinners yrkesdeltakelse har fătt særlig oppmerksomhet, trolig fordi dette aktualiserer både spørsmålet om den nordiske modellens økonomiske bærekraft og verdier knyttet til kjønnslikestilling.

Det er en nær sammenheng mellom familienes organisering og hvilke behov de samme familiene vil ønske at velferdsstaten skal ivareta. For eksempel vil en familie hvor mor er hjemme med barna ha lite bruk for fedrekvote, subsidierte barnehager og fradragsrettigheter for utgifter til barnepass. For en familie med to yrkesaktive foreldre stiller saken seg annerledes. Hvilke muligheter og begrensninger ulike velferdspolitiske rettigheter skaper, er betinget av hovedmønstrene i måten folk lever på. I Norge har utviklingen fra en- til to-inntektsfamilier funnet sted samtidig med store sosialpolitiske reformer som har gjort lønnet arbeid lettere å velge for kvinner. Utbyggingen av velferdsstaten har foregått gradvis og i vekselvirkning med framveksten av nye familiepraksiser og nye behov i befolkningen (Ellingsæter \& Leira, 2006; Leira, 2002). Med innvandring har vi fått flere innbyggere med verdier, holdninger og familiepraksiser som vi kjenner fra vår egen historie, men som nå er langt mindre utbredt. Når befolkningen på denne måten blir mer mangfoldig, blir det samtidig mer krevende å utforme en politikk som treffer (hele) befolkningens behov (Kavli, 2004). Dessuten er det betydelig samvariasjon mellom holdningsmessige forskjeller og strukturelle forskjeller: utdanning, inntekt og formue er ikke likt fordelt mellom befolkningen med og uten innvandringsbakgrunn. Velferdsstatlige institusjoner som er utformet med utgangspunkt i holdninger og praksiser i majoritetsbefolkningen, vil ikke nødvendigvis virke på samme måte blant personer med andre forutsetninger for å lykkes i norsk arbeidsliv, og som er sosialisert inn i en annen institusjonell og kulturell kontekst.

I Norge møter innvandrere institusjonelle og kulturelle kontekster som både kan forandre og forsterke kjønnsforskjeller i familiens organisering. Hva slike kontekster betyr for 
arbeidsdelingen mellom menn og kvinner, har vært studert med utgangspunkt både i den overordnede innretningen av velferdsstaten, spesifikk politikk og kulturelle normer (Orloff, 1993; Pfau-Effinger, 2005; Sainsbury, 2018). Samfunnets organisering kan påvirke familienes organisering på minst to måter. For det første gjennom å påvirke tilgang til konkrete ressurser og muligheter, og for det andre gjennom å skape normative forventninger om atferd (Hook, 2010). Den institusjonelle og kulturelle konteksten innvandrere møter i Norge, kan dermed tenkes å ha en trippel effekt - én som påvirker atferden gjennom de pragmatiske valgene familien gjør på kort sikt, én som over tid påvirker deres preferanser og normer, og én som påvirker familiens og familiemedlemmenes sosioøkonomiske posisjon og sosiale mobilitet.

\subsection{Tema og forskningsspørsmål}

Velferdsstat og arbeidsliv representerer et sammenvevet system av muligheter, men også begrensinger for hvordan familiene kan ordne hverdagen. Den norske velferdsstaten har gått langt i å påta seg oppgaver som tradisjonelt har vært tillagt familiesfæren (Esping-Andersen, 1990; Korpi, Ferrarini, \& Englund, 2013). Innvandrere med bakgrunn fra mer kjønnstradisjonelle samfunn, møter dermed et samfunn som er annerledes enn de er vant med langs flere dimensjoner. De treffer et samfunn som har lagt til rette for høy kvinnelig sysselsetting, men der kvinner fortsatt i betydelig grad arbeider deltid. De treffer et godt utbygd, offentlig subsidiert barnetilsyn også for de yngste barna, og et samfunn der det er velferdsstaten, ikke slekt og familie, som skal ivareta behovene dine hvis du blir syk, står uten arbeid eller når du blir gammel. De treffer et omfattende system av sosiale rettigheter, men der en del av disse rettighetene er knyttet opp til sysselsetting og til lønnsnivå. Og de som kommer som flyktninger, eller som står utenfor arbeidslivet, treffer et omfattende integreringsregime som er ment å tilføre kunnskap om det norske samfunnet, tydeliggjøre forventninger og legge til rette for økt yrkesdeltakelse både blant kvinner og menn.

Det overordnede temaet for avhandlingen er hvordan innrettingen av velferdsstat og arbeidsliv kan forme ulike institusjonelle mulighetsrom og gjennom dette påvirke innvandreres holdninger og praksiser rundt organiseringen av familielivet. Jeg er særlig opptatt av forholdet mellom innvandreres økonomiske og kulturelle tilpasninger, og samspillet mellom disse tilpasningene og den norske institusjonelle konteksten. Dette blir nærmere belyst i fire sett av delspørsmål:

1 I hvilken grad sammenfaller holdninger og praksis knyttet til familiens organisering og hvordan er dette relatert til den norske institusjonelle konteksten?

2 Hvordan kan vi forstå familiepraksis med utgangspunkt i arbeidslivets muligheter og begrensninger for innvandrede kvinner?

3 Hvordan påvirker integreringspolitikkens implementering hvilke forventninger som formidles til nyankomne innvandrere om kvinners yrkesdeltakelse?

4 Hvilken betydning har eksponering for den norske konteksten for holdninger til mødres yrkesdeltakelse blant innvandrere og deres etterkommere? 
Temaet for avhandlingen berører flere av de store debattene innen migrasjonsforskningen, som spørsmålet om relasjonen mellom økonomisk og sosiokulturell integrering, og betydningen av samspillet mellom egenskaper ved migrantene og bostedskonteksten for hvordan integreringsprosessene utvikler seg over tid. Samtidig har kvinners økonomiske integrering i liten grad blitt belyst innenfor de store migrasjonsteoriene. I avhandlingen trekker jeg derfor inn perspektiver fra litteraturen om velferdsstat, arbeid og familie og hvordan disse institusjonene legger rammer for familienes organisering og kvinners yrkesdeltakelse. Denne forskningen er i hovedsak basert på studier av personer uten innvandringsbakgrunn. Ved å bringe inn perspektiver fra denne litteraturen, kan likevel samspillet mellom innvandreres bakgrunn og samfunnets organisering tre klarere fram.

\subsection{Disposisjon}

Avhandlingen består av fire publiserte artikler og denne kappen. I kapittel 2 beskriver jeg hovedtrekk ved de landgruppene som er inkludert i utvalget, samt den institusjonelle konteksten innvandrere møter i Norge og hvordan den har endret seg over tid. Jeg har konsentrert meg om familiepolitikk, integreringspolitikk og arbeidsliv. I kapittel 3 drøftes de viktigste teoretiske tilnærmingene og perspektivene jeg har brukt. I kapittel 4 presenteres de metodiske refleksjonene som ligger til grunn for valg av forskningsdesign, før jeg diskuterer styrker og svakheter ved data jeg har benyttet. Analysene spenner vidt empirisk. Artikkel 1 og 4 er basert på en surveyundersøkelse blant 1821 innvandrere og etterkommere, støttet av registerdata og fokusgrupper. Innvandrere fra Irak, Iran, Pakistan og Vietnam er inkludert i surveyundersøkelsen, samt personer uten innvandringsbakgrunn og personer som er født i Norge av to foreldre som har innvandret fra Pakistan (heretter omtalt vekselvis som etterkommere eller barn av innvandrere). Artikkel 2 bygger på registerdata fra ulike administrative registre og inkluderer landgruppene over i tillegg til innvandrere fra Somalia. Artikkel 3 bygger i hovedsak på kvalitative intervjuer og fokusgrupper med lærere, programrådgivere og deltakere i introduksjonsprogram for nyankomne flyktninger og innvandrere. Hver av artiklene presenteres kort i kapittel 5, før empiriske hovedfunn, teoretiske implikasjoner og forslag til videre forskning drøftes i kapittel 6. 


\section{Innvandrere og den norske konteksten}

Velferdsstat og arbeidsliv representerer et sammenvevet system av muligheter, men også begrensninger, rundt familieliv og kvinners yrkesdeltakelse. Ved migrasjon endres rammene noen ganger betydelig. Samspillet mellom innvandreres medbrakte ferdigheter og ressurser, de demografiske, sosiale og økonomiske trendene i det landet de flytter til, og de historisk forankrede sosiale, politiske og økonomiske institusjonene i bostedslandet, er sentrale for å forstå økonomiske og kulturelle tilpasninger blant migranter (Alba \& Foner, 2014). I dette kapitlet gir jeg derfor først en kort beskrivelse av de landgruppene som får størst oppmerksomhet i avhandlingen. Deretter viser jeg hvilke rettigheter og plikter innvandrere har innenfor det norske velferds- og arbeidslivsregimet, og på hvilke måter de ulike ordningene tas i bruk. Gitt avhandlingens tema, har jeg avgrenset gjennomgangen til områdene familiepolitikk, integreringspolitikk og arbeidsliv. Innvandrere som kom til Norge for 20 år siden, møtte andre institusjonelle strukturer enn innvandrere som kom for 5 eller 10 år siden. Jeg har derfor også beskrevet institusjonenes utvikling over tid.

\subsection{Innvandrere i Norge}

Den innvandrede befolkningen i Norge er svært sammensatt. Forskjeller i utdanningsnivå, språk og helse påvirker muligheter i arbeidslivet, og forskjeller i holdninger og verdier kan påvirke opplevelsen av kulturell avstand. Hvilke grupper man retter søkelyset mot, vil derfor påvirke hvilke mønster som trer fram og hvilke som blir dårligere belyst. Avhandlingen omfatter i hovedsak innvandrere fra Iran, Irak, Pakistan, Somalia og Vietnam. De fleste har kommet til Norge som flyktninger eller som familiegjenforente (se tabell 1.1). Oppholdsgrunnlag og botid i Norge sier både noe om hva slags familie- og integreringspolitikk innvandrere har møtt de første årene i Norge, og hvor lang tid en innvandrer har hatt til å etablere seg. En høy andel pakistanere og vietnamesere har vært over 25 år i Norge, mens irakere og somaliere - to grupper der det fortsatt kommer flyktninger og familiegjenforente - i snitt har kortere botid.

Flyktninger fra Iran er gjennomgående høyere utdannet enn flyktninger fra Vietnam. Blant personer fra Irak har en betydelig andel høyere utdanning, men om lag like mange er registrert med bare grunnskole eller uten utdanning. Muligheten for å finne lønnet arbeid vil dermed variere betydelig for eksempel mellom kvinner fra Somalia, der nesten 60 prosent mangler grunnskole, og kvinner fra Iran, der halvparten har utdanning på universitets- eller høyskolenivå og bare 23 prosent mangler utdanning eller har grunnskole som høyeste nivå. Det er også store variasjoner i sysselsetting. Blant iranske og vietnamesiske kvinner i Norge er henholdsvis 55 og 61 prosent i jobb, mot 29 og 35 prosent blant somaliske og pakistanske kvinner. Et tverrsnitt av 
yrkesdeltakelsen gir likevel bare en del av historien, fordi sysselsettingen vanligvis stiger de første årene etter ankomst til Norge. I landgrupper der mange har kort botid, vil derfor samlet sysselsetting være lavere enn i grupper med lengre botid. Samtidig kan sysselsettingsforløpene variere i ulike deler av en migrasjonsstrøm, både fordi sammensetningen av migranter fra et gitt land kan endre seg og fordi forhold i mottakerlandet kan skifte karakter. Variasjoner i sysselsettingsrater etter botid kan dermed ikke uten videre fortolkes som effekter av å ha bodd lenge(r) i landet.

Hvor tilgjengelige kvinner er for lønnet arbeid, varierer med antall barn. Samlet fruktbarhet (SFT) - et hypotetisk mål som anslår hvor mange barn en kvinne gjennomsnittlig vil få før endt fruktbarhetsalder - har gått ned både i befolkningen sett under ett og blant innvandrere (Tønnessen, 2014). Det er likevel fortsatt store variasjoner mellom landgruppene i materialet. I 2016 varierte SFT fra 1,46 blant innvandrere fra Iran, til 3,16 blant innvandrere fra Somalia. Fruktbarheten reduseres med økt botid i de fleste innvandrergruppene (Byberg, 2002:44).

Tabell 1.1 Oppholdsgrunnlag, botid, utdanningsnivå og sysselsetting i Norge, etter landgruppe. Prosent.

\begin{tabular}{|c|c|c|c|c|c|c|c|c|c|c|}
\hline & \multicolumn{3}{|c|}{$\begin{array}{l}\text { Oppholds } \\
\text { grunnlag (1) }\end{array}$} & \multicolumn{2}{|c|}{ Botid (2) } & \multicolumn{2}{|c|}{$\begin{array}{l}\text { Høyeste utd. } \\
\text { grunnskole } \\
\text { eller lavere (3) }\end{array}$} & \multicolumn{2}{|c|}{$\begin{array}{c}\text { Sysselsatte } \\
\text { (20-66 år) (4) }\end{array}$} & $\begin{array}{c}\text { SFT } \\
(2016)(5)\end{array}$ \\
\hline & FAM & FLY & ARB & 0-11 år & 25 år + & M & $\mathrm{K}$ & M & $\mathrm{K}$ & \\
\hline Iran & 22 & 68 & 6 & 38 & 31 & 26 & 25 & 59 & 55 & 1,46 \\
\hline Irak & 44 & 55 & 1 & 29 & 8 & 49 & 45 & 53 & 42 & 2,31 \\
\hline Pakistan & 76 & 4 & 13 & 24 & 46 & 42 & 48 & 70 & 35 & 2,64 \\
\hline Somalia & 30 & 68 & 2 & 53 & 14 & 69 & 76 & 48 & 29 & 3,16 \\
\hline Vietnam & 49 & 47 & 3 & 18 & 64 & 40 & 42 & 66 & 61 & 1,61 \\
\hline Norge & .. & .. & .. & .. & .. & 26 & 27 & 79 & 76 & 1,67 \\
\hline
\end{tabular}

(1) Basert på Tabell 4.1 Grunnlag for opphold i Norge, etter kjønn og opprinnelsesland, i Vrålstad og Wiggen 2016.

(2) Egne utregninger fra Statistikkbanken, 10598: Innvandrere, etter landbakgrunn, botid og år (2019). Lastet ned 25.05.2019.

(3) Basert på Tabell 9.3 Utdanningsnivå i befolkningen som helhet og blant innvandrere, 16 år og over. Høyeste fullførte utdanning, enten fra opprinnelseslandet eller tatt i Norge, i Vrålstad \& Wiggen (red.) 2016.

(4) Egne utregninger fra Statistikkbanken. Lastet ned 25.05.2019.

(5) Dzamarija (2017), tabell 3.

Utvalget av landgrupper har også betydning, i den forstand at avstanden mellom den institusjonelle og kulturelle konteksten innvandrerne reiste fra, og den de møter i Norge, vil variere. Hensikten her er ikke å gi en omfattende beskrivelse av kulturell og institusjonell «avstand», men å peke på noen sentrale områder der opprinnelses- og bostedskontekst er forskjellig. Som tabell 1.2 viser, er det stor forskjell mellom Norges plassering på FNs Gender development (GDI) og Human development (HDI) indekser og de landene som innvandrere i mine utvalg har bakgrunn fra. Vietnam er rangert vesentlig høyere på GDI enn Iran, Irak og Pakistan, og yrkesdeltakelsen blant kvinner i Vietnam er i dag på nivå med det vi ser blant 
kvinner i Norge. Også fertilitetsnivåene er verdt å notere seg: i Vietnam og Iran er de under 2, mens de blant pakistanske, irakiske og somaliske kvinner varierer fra 3,4 til 6,2. De fleste av informantene kommer fra muslimske land, der vi finner den mest markante avstanden til Norge i synet på kjønnsroller og kjønnslikestilling (Norris \& Inglehart, 2012). Samtidig kan migranter skille seg fra befolkningen som er blitt boende i det landet de migrerer fra. Forholdene i opprinnelseslandet kan også ha endret seg siden migrasjonen. Å ta utgangspunkt i dagens situasjon i opprinnelseslandet er dermed ikke helt presist. Det er likevel nyttig for å gi et grovt riss av forskjellene mellom opprinnelses- og bostedskontekst.

Tabell 1.2 Opprinnelses- og bostedskontekst etter landgruppe

\begin{tabular}{l|ccccl}
\hline & GDI(1) & HDI (1) & $\begin{array}{c}\text { Kvinners } \\
\text { yrkesdeltakelse } \\
\text { (\%) 2018(2) }\end{array}$ & $\begin{array}{c}\text { Fertilitet } \\
2017(2)\end{array}$ & Religion (3) \\
\hline Iran & 142 & 60 & 18 & 1,6 & Islam (98\%) \\
Irak & 147 & 120 & 13 & 4,3 & Islam (95\%) \\
Pakistan & 148 & 150 & 25 & 3,4 & Islam (96\%) \\
Somalia &.. &.. & 20 & 6,2 & Islam \\
Vietnam & 77 & 116 & 79 & 1,9 & Buddhisme (85\%)/Katolisisme (7\%) \\
Norge & 2 & 1 & 75 & 1,7 & Luth.prot. kristendom (72\%) \\
\hline
\end{tabular}

(1) Kilde: United Nations Development Programme. Human Development Reports. Country profiles: http://hdr.undp.org/en/countries Lastet ned 24.05.2019

(2) Kilde: World Bank Open Data, https://data.worldbank.org/indicator/Lastet ned 25.05.2019

(3) Kilde: Store Norske leksikon. Lastet ned 25.05.2019

\subsection{Familiepolitikk}

Norsk familiepolitikk beskrives gjerne som en politikk som bygger opp under kjønnslikestilling, i form av tiltak som fremmer både mødres yrkesdeltakelse og menns tid til omsorg for barn (Rønsen \& Kitterød, 2015). I dag kjennetegnes politikken av sjenerøse foreldrepermisjoner, en egen fedrekvote og et godt utbygd og sterkt subsidiert offentlig barnetilsyn. Dette familiepolitiske systemet omtales gjerne som et forsørger-omsorgsregime, der essensen er likestilte foreldreskap der begge foreldre er involvert i både omsorgsarbeid og lønnsarbeid, og der staten stimulerer omfordeling av barneomsorg fra det private og til det offentlige (Ellingsæter, 2016; Korpi et al., 2013). Samtidig har det norske regimet også visse hybride trekk, med komponenter fra en tradisjonell mannlig forsørgermodell (Korpi et al., 2013).

Velferdsytelsene i Norge legger til rette for at kvinner skal kunne være hjemme i visse livsfaser. Innvandreres bruk av disse familierettede stønadene aktualiserer normative spenninger som annen sosialpolitikk ikke er preget av i like stor grad. Mer spesifikt, så reises det en bekymring for at innvandreres tilgang til økonomiske overføringer, som engangsstønad ved fødsel, kontantstøtte og overgangsstønad for enslige forsørgere, kan svekke oppslutningen om disse 
ordningene i den innfødte befolkningen og dessuten bidra til å vedlikeholde kjønnstradisjonelle praksiser i den innvandrede befolkningen (Bjørnholt \& Stefansen, 2019; Grødem, 2017).

Offentlige overføringer til barnefamilier skjer både i form av ytelser som skal sikre familienes økonomiske situasjon og tjenester som skal gjøre det mulig for begge foreldre å være i lønnet arbeid. I tillegg er det etablert egne skatteordninger for familier med barn. Både mor og far har rett til foreldrepermisjon dersom de har hatt pensjonsgivende inntekt i minst seks av de ti siste månedene før uttaket av foreldrepermisjonen begynner. Foreldre uten rett til foreldrepermisjon får engangsstønad. Kravene om yrkesaktivitet i forkant av foreldrepermisjon skaper store forskjeller i bruken av ordningene mellom den innvandrede og den innfødte befolkningen. Mens bare 8 prosent av mødre født i Norge mottok engangsstønad i 2014, mottok 45 prosent av asiatiske mødre og 64 prosent av afrikanske mødre engangsstønaden (Grambo \& Nicolaisen, 2015). Blant innvandrede fedre fra Afrika, Asia, Latin-Amerika, Oseania utenom Australia og New Zealand, og Europa utenom EU/EØS som fikk barn i 2011, hadde 45 prosent $i k k e$ rett til fedrekvote, mot 7,5 prosent innfødte fedre (Kitterød, Halrynjo, \& Østbakken, 2017:84-85).

God tilgang til rimelige barnehager er en av familiepolitikkens hovedpilarer og har fått en viktig plass også i det offentlige ordskiftet om integrering. Barnehagenes betydning for språklæring er nå framhevet, blant annet $\mathrm{i}$ lys av forskning som tyder på at barnehage letter veien gjennom utdanningssystemet og inn i arbeidslivet for minoritetsspråklige barn (Drange \& Telle, 2015; Havnes \& Mogstad, 2011). I Oslo kommune vedtok bystyret tidlig at minoritetsspråklige barn kunne prioriteres ved opptak til kommunale barnehager. Så lenge barnehager var en knapp ressurs, var det likevel ikke mulig å tilby plass til alle minoritetsspråklige barn som søkte (Djuve \& Pettersen, 1998b). Også prisen ble for høy for mange, både i barnehage (Djuve \& Pettersen, 1998a) og i skolefritidsordningen (Feiring, 1996).

«Barnehageforliket» i 2003 ga makspris på foreldrebetaling og en kommunal plikt til å bygge ut barnehagetilbudet, og i 2009 fikk foreldre rett til barnehageplass. Forsøk med gratis kjernetid ble initiert fra 1998. Ambisjonen var å øke barnehagedeltakelsen blant minoritetsspråklige barn og arbeids- og samfunnsdeltakelsen blant barnas foreldre. I Oslo ser forsøkene ut til å ha økt barnehagebruken blant fire- og femåringer med innvandrerbakgrunn med om lag 15 prosent, og har også hatt målbar effekt på barnas skoleprestasjoner (Bråten, Drange, Haakestad, \& Telle, 2014; Drange \& Telle, 2015). Gratis kjernetid ble innført som en nasjonal ordning i 2015/2016, med 20 timer per uke for 3-5-åringer i familier med lav inntekt.

Flere barnehager, rett til barnehageplass og lavere pris ga en markant vekst i barnehagebruken. Mellom 2001 og 2016 økte andelen barn med barnehageplass fra 53,5 til 76,9 prosent. Også blant minoritetsspråklige økte andelen i barnehage markant - fra 38,4 til 61,3 prosent. ${ }^{1}$ For femåringene er forskjellen mellom majoritets- og minoritetsspråklige barn nå nesten borte. Blant de yngste barna er det fortsatt en lavere andel minoritetsspråklige som går i barnehage

\footnotetext{
${ }^{1}$ Kilde: https://www.ssb.no/utdanning/artikler-og-publikasjoner/hvordan-gar-det-med-innvandrere-og-deres-barni-skolen
} 
(NOU 2017: 6:174), og kontantstøtten trekkes fram som en mulig forklaring. Ordningen ble innført i 1998-1999 for barn mellom 1 og 3 år som ikke benyttet seg av barnehage. I 2012 ble stønaden fjernet for toåringer, mens satsen for barn mellom 13 og 23 måneder er hevet i flere omganger. ${ }^{2}$ Kontantstøtten representerer med sin tydelige støtte til en mer tradisjonell familieorganisering, det klareste avviket fra hovedsporet i norsk familiepolitikk (Ellingsæter, 2016), og er politisk omstridt. Samtidig har både bruken og sammensetningen av brukerne endret seg kraftig. Fra 1999 til 2016 sank andelen kontantstøttemottakere fra 76 til 23 prosent 3 . Reduksjonen har vært betydelig også blant innvandrede foreldre - fra nærmere 80 til 43 prosent. Samlet sett var likevel andelen som mottok kontantstøtte vesentlig høyere i den innvandrede (43\%) enn i den innfødte befolkningen (15\%) (Hamre, 2017). Dette har skapt bekymring for at ordningen kan svekke innvandrede kvinners deltakelse i kvalifisering og arbeidsliv, og for at barna mister en (tidlig) start på opplæringsløpet. I 2017 ble det derfor innført et krav om at begge foreldre må ha vært medlem i folketrygden i fem år (dersom begge bor sammen med barnet) for å ha rett til kontantstøtte 4 . Dette er trolig forklaringen på at andelen med innvandringsbakgrunn som mottar kontantstøtte er redusert fra 43 prosent i 2016 til 28 prosent i 2018 (Sandvik \& Gram, 2019).

Også når det gjelder stønad til enslige foreldre har innvandreres bruk av ordningen vekket debatt. Overgangsstønaden gis til enslig mor eller far som midlertidig er ute av stand til å forsørge seg selv ved lønnet arbeid på grunn av omsorg for barn eller nødvendig utdanning. Etter at retten til stønaden ble redusert fra ti til tre år i 1998, var ordningen ifølge Grødem (2017) lite debattert før innvandreres bruk av den igjen satte innstramminger i ordningen på dagsorden. Blant somaliske og irakiske mødre var andelen som mottok stønaden høyere enn i befolkningen ellers (Bratsberg, Røed, \& Raaum, 2011; Kavli, Nielsen, \& Sandbæk, 2010), og i NAV ble ikke kvinner som allerede hadde en inntektssikring gjennom overgangsstønaden prioritert for oppfølging i en - for NAV - allerede presset arbeidssituasjon (Kavli et al., 2010). Grødem (2017) påpekte hvordan dette vekket bekymring for at stønaden kunne bremse kvinners yrkesdeltakelse, og denne bekymringen utgjorde en del av bakteppet for tilstrammingen i aktivitetsplikten til å gjelde fra barnet fyller ett år.

Kontantstøtten og overgangsstønaden er to eksempler på familiepolitiske ordninger som er kommet i spill i kjølvannet av økt innvandring. Her har politikken beveget seg i retning av å redusere tilgangen til ytelser. Innvandrere som ikke har lønnet arbeid, tjener imidlertid ikke opp rettigheter innenfor «hovedsporet» i familiepolitikken, og er dermed henvist til ulike former for kontantytelser som er mindre sjenerøse, men mer tilgjengelige. Bruk av barnehage har økt kraft blant innvandrere, etter at tilgjengeligheten steg og prisen sank. Dette legger til rette for innvandrede kvinners deltakelse i kvalifisering og lønnsarbeid.

\footnotetext{
2 Rundskriv, Hovednr. 34 - Lov om kontantstøtte til småbarnsforeldre (kontantstøtteloven) Generell del https://www.nav.no/rettskildene/Rundskriv/hovednr.34-lov-om-kontantst\%C3\%B8tte-tilsm\%C3\%A5barnsforeldre-kontantst\%C3\%B8tteloven-generell-del

3 Fram til 2011 gjelder andelen mottakere barn mellom 13 og 36 måneder, fra og med 2012 barn mellom 13 og 23 måneder. (Hamre 2017)

${ }^{4}$ https://www.regjeringen.no/no/aktuelt/botidskrav-for-kontantstotte-innfores/id2563824/
} 


\subsection{Integreringspolitikk}

Norsk integreringspolitikk har vært gjennom en omfattende endring fra midten av 1970-tallet og fram til i dag. Diskursivt kan endringen beskrives som en dreining i fokus fra «retten til å være forskjellig» til «plikten til å delta» (Djuve \& Kavli, 2007:204). Fram til midten av 1990-tallet var norsk integreringspolitikk preget av en oppfatning om at samfunnet i minst mulig grad skulle påtvinge innvandrere majoritetens verdier og livspraksiser, og det ble lagt stor vekt på at innvandrede minoriteter selv skulle få avgjøre hvilken form for tilpasning til det norske samfunnet de ønsket (Brochmann, Borchgrevink, \& Rogstad, 2002). I løpet av 1990-tallet endret den politiske diskursen rundt integreringspolitikken seg. Fra flere hold ble det ytret bekymring, særlig knyttet til tre forhold (Djuve \& Kavli, 2007:205). For det første at sosialhjelpen kunne virke klientifiserende - altså at hjelpen bidro til å redusere innvandrernes muligheter for å bli økonomisk selvhjulpne. For det andre at kvaliteten på kvalifiseringsarbeidet var for dårlig. Yrkesdeltakelsen var lav, spesielt blant kvinner, og innvandrere fikk ikke den opplæringen de trengte for å få innpass i norsk arbeidsliv. Og for det tredje at politikken ikke tok inn over seg at en del innvandrere hadde praksiser som var i strid med kvinners rettigheter. Lav yrkesdeltakelse blant innvandrede kvinner og medieoppslag om tvangsekteskap og kvinnelig kjønnslemlestelse skapte bekymring for at det var en (stor) avstand i holdninger og verdier som rådende politikk ikke tok høyde for (se f.eks. Akkerman \& Hagelund, 2007). Gradvis vokste det fram et bilde av norsk integreringspolitikk som mislykket, og behovet for reformer rykket oppover på den politiske agendaen (Djuve \& Kavli, 2007).

Arbeidslinja i norsk politikk bygger på et prinsipp om at rettigheter og plikter i velferdspolitikken knyttes tettere sammen ved at mottakerne av stønader får en plikt til å delta i ulike former for aktiveringstiltak (Øverbye \& Stjernø, 2012:19). I 2003 ble introduksjonsloven vedtatt, og arbeidslinja i norsk politikk fikk med det sitt kanskje sterkeste uttrykk. Loven er et klassisk eksempel på en aktiveringspolitikk der opplæringstiltak som skal bedre deltakernes muligheter på arbeidsmarkedet, kombineres med sanksjoner og insentiver som skal regulere atferd. Nettopp kombinasjonen av investering og sanksjonering var en viktig årsak til at loven fikk oppslutning både på høyre og venstre side av norsk politikk (Djuve, 2011). Deltakerne fikk rett til omfattende opplæring, kombinert med en romsligere og mer forutsigbar inntektssikring. Samtidig ble økonomisk støtte betinget av deltakelse i opplæring, og ugyldig fravær ble sanksjonert økonomisk. Introduksjonsloven var et første signal om en strammere linje også for andre grupper som var avhengige av offentlige overføringer. Fra 2008/2009 kunne langtidsmottakere av sosialhjelp, herunder mange innvandrere, sluses inn $\mathrm{i}$ Kvalifiseringsprogrammet (KVP), der kombinasjonen av inntektssikring og aktivering var utformet etter samme mal som i introduksjonsprogrammet. I dag er KVP mindre brukt, men nye, ordninger som Ny sjanse og Jobbsjansen har kommet til spesifikt for innvandrere som ikke lenger er å betrakte som «nyankomne».

Introduksjonsloven ble løftet fram som et spesifikt bidrag til å fremme innvandrede kvinners rettigheter og muligheter. Utvalget som utarbeidet lovforslaget mente at inntektssikringen burde stimulere til deltakelse for alle familiemedlemmer, ikke bare den som «måtte definere seg 
som hovedforsørger», og begrunnet dette blant annet med hensyn til kjønnslikestilling (NOU 2001: 20 side 103). I Jobbsjansen del B er ambisjonen å øke yrkesdeltakelsen blant hjemmeværende innvandrede kvinner som ikke er avhengige av sosialhjelp, men som har behov for grunnleggende kvalifisering for å kunne skaffe lønnet arbeid. ${ }^{5}$ Ambisjonen om å øke innvandrede kvinners yrkesdeltakelse omfatter dermed nå også kvinner som ikke er avhengige av sosialhjelp.

Integreringspolitikken følger langt på vei hovedsporet i familiepolitikken, med ambisjoner om å legge til rette for toforsørgerfamilier. Dette er tydelig både innenfor introduksjonsordningen, der økonomiske ytelser knyttes direkte til deltakelse for både menn og kvinner, og i forbindelse med kontantstøtten, der nye regler etableres for å redusere de (kortsiktige) økonomiske insentivene for å ikke delta i opplæringstiltak. I noen deler av den innvandrede befolkningen er likevel yrkesdeltakelsen lav, også etter introduksjonsperioden (Bratsberg, Røed \& Raaum 2011; Djuve et al. 2017; Vrålstad \& Wiggen 2017) Manglende opptjening av rettigheter i arbeidslivet gjør at disse familiene møter andre deler av de familiepolitiske ordningene med potensielt andre insentiveffekter.

\subsection{Arbeidsliv}

Den norske velferdsmodellen henger tett sammen med strukturene i det organiserte arbeidslivet. Hovedbildet er dette: Velferdsstaten sørger for gratis utdanning til innbyggerne og kvalifisert arbeidskraft til et stadig mer kompetansekrevende arbeidsliv. For de som faller utenfor arbeidslivet, er det etablert et økonomisk sikkerhetsnett. Høy sysselsetting og et organisert arbeidsliv bidrar på sin side med god skatteinngang som er med på å finansiere de ulike velferdsordningene (Brochmann \& Grødem, 2017; Dølvik, 2013). En jevn inntekts- og lønnsfordeling innebærer at lavt utdannet arbeidskraft er relativt godt lønnet, sammenliknet med andre land, og at høyt utdannet arbeidskraft relativt sett er lavere betalt. Ut fra generell, $\emptyset$ konomisk teori tilsier dette at Norge vil tiltrekke seg lavt utdannet arbeidskraft utenfra (Borjas, 1999). Samtidig er terskelen inn i norsk arbeidsliv høy: en økende andel personer uten videregående skole er uten lønnet arbeid (NOU 2018: 13), og avstanden mellom kompetansen innvandrere har med seg ved ankomst til Norge og de kravene som stilles i norsk arbeidsliv, øker (Djuve \& Kavli, 2019; NOU 2018: 13). I takt med at andelen minoritetsspråklige arbeidstakere har økt i norske virksomheter, har stadig flere arbeidsgivere også begynt å stille krav om dokumenterte norskferdigheter i tillegg til øvrige kompetansekrav (Nicolaisen, Kavli, \& Trygstad, 2019). Krav om bestått norskprøve er innført på nasjonalt nivå fra 2017 for

\footnotetext{
5 https://www.imdi.no/tilskudd/tilskudd-til-jobbsjansen--kvalifiseringsprosjekter-for-hjemmevarendeinnvandrerkvinner/
} 
arbeidstakere fra land utenfor EU i helsesektoren ${ }^{6}$ og i 2018 for ansettelse i barnehager ${ }^{7}$ - to sektorer som har fungert som viktige rekrutteringskanaler for innvandrere.

Politiske ambisjoner om å fremme foreldres mulighet til å kombinere lønnet arbeid og omsorg for barn kommer også til uttrykk i arbeidslivets reguleringer. Arbeidsmiljøloven gir yrkesaktive foreldre rett til lønnet permisjon ved barns, eller barnepassers, sykdom fram til det året barnet fyller 12 (§ 12-9). Fulltidsarbeidende kvinner har krav på en time lønnet fri hver dag, slik at de kan fortsette å amme barnet fram til det fyller ett år (§ 12-8), og, dersom det ikke er til vesentlig ulempe for virksomheten, åpner arbeidsmiljøloven (§ 10-2) for at arbeidstakere kan jobbe redusert dersom vektige velferdsmessige behov taler for det. Å ha barn under 10 år, eller å være enslig forsørger, anses her som en vektig grunn.

Det arbeidslivet som innvandrere møter i Norge, er preget av høy kvinnelig yrkesdeltakelse, men det er også svært kjønnsdelt. Åttifem prosent av arbeidstakere i Norge jobber i et kvinne- eller mannsdominert yrke (kvinneandelen er enten høyere enn 60 prosent eller lavere enn 40 prosent). Kvinner er overrepresentert i offentlig sektor, menn i privat sektor. Kjønnsforskjellen i sektortilhørighet har økt de siste 20 årene, selv om det også er tegn til endring blant unge, og blant innvandrere (Østbakken, Reisel, Schøne, Barth, \& Hardoy, 2017). Avtalt arbeidstid i Norge er - i internasjonal sammenheng - kort (Messenger, Lee, \& McCann, 2007). Kvinner arbeider likevel deltid i langt større grad enn menn, men andelen mødre som arbeider heltid har økt sterkt (Ellingsæter \& Jensen, 2019).

Selv om foreldres formelle rettigheter til tilpasninger av hensyn til omsorg for barn komparativt sett er velutviklet i Norge, vil arbeidstakeres muligheter til å benytte seg av dem variere. Dette handler både om hvor etterspurt arbeidstakerens kompetanse er, og om egenskaper ved den delen av arbeidslivet han eller hun har fătt innpass i. I arbeidslivsforskningen har dette temaet blitt belyst blant annet i litteraturen om todelte arbeidsmarkeder (Doeringer \& Piore, 1971), arbeidsmarkedssegmentering (Rubery, Earnshaw, Marchington, Cooke, \& Vincent, 2002) og i litteraturen om dualisering av arbeidstakeres rettigheter (Emmenegger, Häusermann, Palier, \& Seeleib-Kaiser, 2012). Innvandrere generelt (se for eksempel Heath \& Cheung, 2007; Kalleberg, 2011; Standing, 2011), og innvandrede kvinner spesielt (Rubin et al., 2008), er overrepresentert i de dårligst regulerte delene av arbeidslivet. Formelle institusjoner treffer dermed ulike grupper på ulike måter, og i noen grupper kan utfallet bli at de økonomiske insentivene for å søke lønnet arbeid svekkes. Den norske modellens kombinasjon av høye kompetansekrav og relativt sjenerøse sosiale ytelser, kan både gjøre det vanskeligere å få innpass i arbeidslivet og redusere de økonomiske insentivene for å søke lønnet arbeid for innvandrere med lav utdanning (Brochmann \& Grødem, 2017:5). Marginalskatten på lave inntekter kan bli særlig høy innenfor det norske regimet, der en rekke sosiale kontantoverføringer utformes på bakgrunn av familiestørrelse, mens lønnsinntekt ikke påvirkes av hvor mange barn man har. Dette treffer særlig innvandrede familier fra landgrupper der fertiliteten er høy, som Somalia, Pakistan og

\footnotetext{
${ }^{6}$ https://fagbladet.no/reportasjer/dette-er-sprakkravene-i-helse-og-omsorgssektoren-6.91.595907.199526bc07

7 https://www.udir.no/regelverkstolkninger/barnehage/bemanning/krav-om-norskferdigheter-for-a-bli-ansatt-ibarnehage
} 
Irak. Både evnen og viljen til å stå i lønnet arbeid over tid kan også påvirkes av arbeidsbetingelsene. Innvandrere er mer utsatt for belastninger og ulykker på arbeidsplassen, har mindre kontroll over eget arbeid, opplever i mindre grad at de får utnytte sine ferdigheter og sin kunnskap i jobben, og har oftere - og over lengre tid - jobber de formelt er overkvalifisert for (Vrålstad \& Wiggen, 2017). Innvandrere er også oftere midlertidig ansatt, jobber oftere ufrivillig deltid (Vrålstad \& Wiggen, 2017) og har større risiko for å miste jobben i økonomiske nedgangstider (Bratsberg et al., 2018). 


\section{Teoretiske perspektiver}

Avhandlingens analytiske ramme er inspirert av flere teoritradisjoner. Først vil jeg ta for meg migrasjonsforskningens generelle teorier om integrerings- og assimileringsprosesser blant innvandrere. Denne litteraturen er interessant fordi den er opptatt av langsiktige tilpasningsprosesser, og fordi den tematiserer forholdet mellom kulturelle og strukturelle dimensjoner i disse prosessene. Kjønnsforskjeller i tilpasningsprosessene, eller mer spesifikt, kvinners økonomiske integrering, er imidlertid lite tematisert. Her trekker jeg derfor på teorier om arbeid og familie - både mikroøkonomiske teorier knyttet til kost-nytte-maksimering og verdibaserte teorier om normative føringer for individers atferd. Jeg drøfter også hvordan institusjoner kan trekkes inn både som en ramme for mikroøkonomiske vurderinger og som en selvstendig faktor som kan påvirke holdninger og verdier.

\subsection{Perspektiver på migranters sosiokulturelle integrering}

I sosiologisk teori henviser integrasjon til hvordan ulike deler i et sosialt system inngår i en helhet og individer blir gjort, eller gjør seg selv, til en del av helheten (Brochmann, 2017, 23 oktober). Selve begrepet «å integrere» betyr «å gjøre fullstendig, å fullføre» (Østerberg, 1984:24), og integrasjon kan dermed både betegne en prosess og en tilstand. Begrepets positive valør følger av den klart negative motsatsen til integrering: marginaliserte individer eller, i ytterste konsekvens, et desintegrert samfunn (Favell, 2001). På tross av sin positive valør er integrering likevel et omstridt begrep i migrasjonslitteraturen, fordi det er uenighet om hva innvandrere skal integreres i og hvor stort rommet for forskjellighet kan og bør være. Den lineære forståelsen av assimilering der innvandrere erstattet egen kultur med vertslandets, møtte i etterkrigstiden sterk kritikk for å være etnosentrisk og for å overse betydningen av makt, kultur og strukturelle forhold (Alba \& Nee, 2005:4-6). Pendelen svingte nå i retning av å studere sosioøkonomisk integrasjon, mens innvandreres kulturelle tilpasningsprosesser enten ikke ble tematisert, eller ble behandlet som et spørsmål om hvordan majoriteten konstruerte innvandrere og minoriteter som «annerledes» (Friberg \& Midtbøen, 2017: 9-10). På slutten av 1990-tallet forkastet Alba og Nee (2005) etterkrigstidens assimileringsbegrep og lanserte i stedet sin neoklassiske assimileringsteori. Assimilering forstås her ikke som en enveis prosess der minoriteten blir identisk med majoriteten, men som en prosess der kulturelle og symbolske grenser gradvis spiller en mindre rolle i menneskers liv. Kulturell assimilering blir dermed ikke bare et spørsmål om hvordan innvandrere tar til seg majoritetens kultur og væremåte (boundary crossing), men også om hvordan kulturelle grenser mellom majoritet og minoritet kan flyte sammen (boundary blurring) og på den måten bli mindre relevante. Grensene mellom 
ulike deler av befolkningen kan også flyttes, slik at nye grupper eller praksiser innlemmes som en del av majoritetskulturen (boundary shifting). Alba og Nees forståelse av assimileringsprosesser tangerer dermed de mest utbredte definisjonene av integrering, som beskriver dette som en toveis prosess der minoritet og majoritet påvirker hverandre og sammen bidrar til å skape noe nytt (Hagelund \& Kavli, 2017). Med unntak av der jeg direkte refererer litteraturen, bruker jeg videre i teksten begrepene økonomisk og kulturell integrering.

Migrasjonsforskningen er interessant for meg fordi den er opptatt av de langsiktige tilpasningsprosessene og fordi den tematiserer forholdet mellom de kulturelle og de strukturelle dimensjonene i disse prosessene. Innenfor neo-assimileringslitteraturen er tesen at kulturell endring oppstår som en uintendert konsekvens av forsøket på å oppnå en økonomisk mobilitet. Selve adapsjonsprosessen er på denne måten et resultat av migranters intensjonelle handlinger for å skape seg et godt liv, men også av pragmatiske og mindre intensjonelle tilpasninger til nye strukturer. I dette perspektivet følges kulturell og økonomisk integrering ad. Innvandrere som

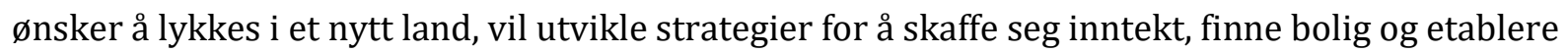
et sosialt nettverk. Ved å lære seg språket og gjennom kulturelt betingede normer for passende atferd i ulike sosiale sammenhenger, signaliseres en kulturell og sosial kompetanse som gjør det mulig å konkurrere om jobber og posisjoner. Og selv om intensjonen kan være å videreføre både språk og skikk fra opprinnelseslandet, så kan dette være krevende å realisere over tid, og spesielt over generasjoner (Alba \& Nee, 2005). Kulturell integrering vil i dette perspektivet skje gradvis, langsomt og ofte uintendert. Det skjer, enkelt sagt, som en slags bieffekt mens du forfølger andre mål. Nee og Alba (2013:359) bruker termen «kontekst-bundet rasjonalitet» for å beskrive hvordan slike kulturelle endringer oppstår. Individer og familier agerer rasjonelt, men innenfor konkrete, institusjonelle «matriser» som former det mulighetsrommet de opererer innenfor. Holdninger, normer, regler og organisasjoner inngår her som en del av den matrisen som former sosial atferd. Migranters økonomiske og kulturelle integrering blir på denne måten et produkt av flere sett av mekanismer som opererer på ulike nivåer. Her spiller både migrantenes individuelle ressurser inn, de ressursene som følger av å tilhøre en gruppe og de dypere mekanismene som er knyttet til de mer overordnede strukturene i bostedslandet (Alba \& Foner, 2014; Nee \& Alba, 2013).

Forventningen om en positiv sammenheng mellom økonomisk og kulturell integrering har blitt kritisert innenfor segmentert assimileringsteori (Portes \& Rivas, 2011; Portes \& Rumbaut, 2001; Portes \& Zhou, 1993). Kritikken bunner i en grunnleggende uenighet i teoretisk perspektiv. Der neo-assimileringsteori bygger på en forutsetning om at endringer i kulturelle grenseoppganger mellom grupper er en mekanisme som skaper sosial mobilitet, er segmentert assimileringsteori strukturalistisk: kulturell tilpasning er ikke uvesentlig, men endring i klasseposisjoner betyr mer (Friberg \& Midtbøen, 2017). Det viktige spørsmålet blir i dette perspektivet ikke om innvandrere og deres etterkommere blir assimilert, men hvilket samfunnssegment de blir assimilert inn i. Fordi mange innvandrere møter diskriminering og et dualisert arbeidsliv, vil ikke den beste strategien nødvendigvis være å tilpasse seg majoritetens holdninger, verdier og praksiser. Det kan tvert imot lede til assimilering inn i en underklasse med dårlige livsbetingelser. Opplevelse av dårlige muligheter for sosial mobilitet kombinert med en avstand i religion, religiøsitet og 
verdisyn, har også vært fremmet som årsak til at innvandrere og etterkommere over tid kan bevege seg lenger vekk fra de holdninger som dominerer i majoritetsbefolkningen. Et alternativ er i henhold til segmentert assimileringsteori en delvis, eller selektiv akkulturasjon. Innvandrere lærer seg språket og blir kjent med kulturen i det landet man bor, men viderefører opprinnelseslandets språk, verdier og holdninger. Dette kan gi større mulighet for å trekke veksler på et nettverk med samme bakgrunn som en selv, større selvtillit gjennom bekreftelse av egne verdier og tradisjoner, og, i siste instans, større muligheter for å lykkes i å skape et godt liv.

Kjønnsroller og kvinners status er et av de områdene der ulike samfunn viser vedvarende forskjeller (Inglehart \& Norris, 2003). Praksis på dette området hører til et av de mest fundamentale aspektene ved et samfunns normative struktur. Det er derfor ikke overraskende at det er her noen av de mest intense konfliktene rundt integrering oppstår (Prieur, 2002), spesielt når det gjelder ikke-vestlige innvandrere i europeiske samfunn (Röder, 2014). Som jeg beskriver i kapittel 2, utgjør toforsørgerfamilien hovedsporet i norsk familie- og velferdspolitikk, og integreringspolitikken har i økende grad innført tiltak for å øke kvinners yrkesdeltakelse. Dette kan gjøre det krevende for innvandrere med kjønnstradisjonelle holdninger å leve i tråd med sine holdninger, samtidig som de skal finne strategier for å lykkes økonomisk. I 1957 utviklet Leon Festinger en teori om kognitiv dissonans for å forklare de psykologiske prosessene som påvirker hvordan mennesker løser situasjoner der det ikke er samsvar mellom holdninger og handlinger. Fordi kognitiv dissonans vanligvis er ubehagelig, vil de fleste forsøke å redusere dette ubehaget, enten ved å endre atferd, eller ved å endre holdninger. Hvor viktig det oppleves å gjenopprette kognitiv konsistens er blant annet betinget av om dissonansen kan tilskrives forhold som er utenfor den enkeltes kontroll (Festinger \& Carlsmith, 1959; Himmelweit \& Sigala, 2004), og av hvor viktig den aktuelle handlingen eller holdningen er for selvbildet (Stone \& Fernandez, 2008). Hvordan vi organiserer familielivet er nært forbundet med hva vi oppfatter som et godt og et riktig liv. Det er dermed rimelig å anta at dissonans her vil oppleves som ubehagelig og kan skape et behov for å endre enten holdningene eller praksisen. På den andre siden kan det tenkes at innvandrere som befinner seg i en ny kontekst, vil ha en høyere toleranse for kognitiv dissonans i tilfeller der hvor bostedslandets organisering gjør det vanskelig å leve i tråd med preferansene. Tilbøyeligheten til å redusere kognitiv dissonans tilsier uansett at et sammenfall mellom holdninger og handlinger ikke nødvendigvis kan tolkes som et uttrykk for at en person har realisert sine egne preferanser (se også kapittel 3.3 og 4.3).

\subsection{Perspektiver på institusjonenes rolle}

Nordamerikansk migrasjonsforskning har levert sentrale bidrag til forståelsen av migranters integreringsprosesser. De bør likevel suppleres med studier som tar hensyn til ulike nasjonale kontekster i de landene innvandrere bosetter seg (Crul \& Schneider, 2010). Dette er i senere år blitt tema for et økende antall studier fra europeiske migrasjonsforskere (Careja, 2019; Crul, Schneider, \& Lelie, 2012; Kogan, 2006, 2016; Söhn, 2013). Denne forskningen har likevel i liten grad tematisert hvordan institusjoner knyttet til arbeidsliv og velferdsstat kan påvirke 
familiepraksis og kvinners yrkesdeltakelse. Her er den norske konteksten spesielt interessant, fordi de institusjonelle strukturene er så sterkt innrettet mot toinntektsfamilien og kjønnslikestilling.

Innenfor samfunnsvitenskapene finnes det en rekke ulike betydninger og definisjoner av begrepet institusjon (Peters, 2019; Scott, 2014). La meg derfor klargjøre hvordan jeg benytter begrepet i min avhandling. I bred forstand forstår jeg institusjoner som sosialt sanksjonerte og kollektivt implementerte forventninger til hvilken atferd ulike typer av aktører skal utvise i bestemte situasjoner. I dette perspektivet kan institusjoner komme til uttrykk gjennom formelle lover og reguleringer, gjennom myndighetspersoners fortolkning og iverksetting av disse, og gjennom de sosialt sanksjonerte, men likevel mer uformelle forventningene om atferd som er knyttet til bestemte aktørers handlinger i bestemte situasjoner (Streeck \& Thelen, 2005:9). Jeg vil legge hovedvekten på betydningen av institusjoner slik de kommer til uttrykk gjennom organiseringen og implementeringen av velferdsstat og arbeidsliv.

Institusjoners utforming, og de rammene det legger for individers liv, kan påvirke hva som oppfattes som mulig og i individers interesse, men også produsere en «normativ feedback» som påvirker oppfatningene om hva som er ønskelig (Soss \& Schram, 2007; Svallfors, 2010). Goerres og Tepe (2012) bruker begrepet regimesosialisering for å beskrive hvordan ikke bare praksis, men også holdninger kan formes av institusjonell kontekst. For eksempel kan personer som vokser opp i en spesifikk velferdsstat, preges i sitt sett av forventninger til hva velferdsstaten kan og bør tilby dem. Disse forventningene kan bygge på erfaring med institusjonene, men også på en tillit til at velferdsinstitusjonene faktisk leverer de tjenestene du har behov for den dagen du trenger dem (Taylor-Gooby, 2008). Innvandrere som har bakgrunn fra konfliktområder, fra regimer med svakt utbygde offentlige tjenester og fra land med utbredt korrupsjon, ser ut til å ha stor tillit til bostedslandets institusjoner når de først ankommer. Over tid synker tilliten noe, og stabiliseres på om lag samme nivå som i befolkningen for øvrig (Maxwell, 2010; Röder \& Mühlau, 2011, 2012). Hva som skjer i møtene mellom innvandrere og bostedslandets institusjoner som kan påvirke tilliten, er foreløpig lite studert. Kumlin og Rothstein (2005) argumenterer for at velferdsstatens institusjoner - og erfaringene innbyggerne gjør når de møter disse institusjonenes representanter og regelverkets konsekvenser - kan bidra til å skape forventninger og tillit, men også bryte ned tilliten.

Også arbeidslivet kan påvirke individers oppfatninger av hva som er mulige og ønskelige tilpasninger. En implikasjon av neo-assimileringsteoriens antakelse om at kulturell integrering er en rasjonell, om enn ofte utilsiktet konsekvens av innvandreres jakt på økonomisk integrering, er at det finnes en mulighet for økonomisk mobilitet. Innvandrere må få tilgang til arbeidsmarkedet og mulighet til å avansere fra jobber med dårlige betingelser. Dette premisset forutsetter at arbeidstakere som starter i en «dårlig jobb», kan bruke dette som et springbrett til bedre jobber (Gash, 2008a). Dersom arbeidsmarkedet derimot er delt i et primært arbeidsmarked med gode betingelser, og et sekundært arbeidsmarked med dårligere forhold, kan en slik mobilitet, for deler av befolkningen, være langt mer krevende å realisere (Doeringer \& Piore, 1971; Kalleberg, 2009; Rubery et al., 2002; Rueda, Wibbels, \& Altamirano, 2015). 
På makronivå sosialiserer hvert regime sine innbyggerne til å forvente en viss type tjenester eller strukturer. I Norge handler dette blant annet om at velferdsstaten skal sørge for individers behov i utsatte livsfaser, men også om at strukturer skal være på plass som gjør det mulig å kombinere lønnsarbeid og omsorgsarbeid. Samtidig kan disse tjenestene og strukturene skape normative føringer, for eksempel knyttet til kvinners yrkesdeltakelse. Innvandrere fra de landene som er inkludert i min studie, er sosialisert inn i en struktur der familien, ikke staten, er garantist for individets behov i sårbare livsfaser. I den grad det er en sammenheng mellom samfunnets organisering og de normene som individer har om hva som er den beste måten å organisere familielivet på, vil det dermed kunne se svært ulikt ut i ulike grupper.

Velferdsstatens kapasitet til å påvirke praksis og holdninger dreier seg ikke bare om institusjoner slik de er nedfelt i lover og regler og hvordan de ulike aspektene ved disse institusjonene samvirker. Det handler også om hvordan institusjoner formidles og politikken de representerer implementeres. Innvandrere møter det norske samfunnet gjennom overordnede strukturer, men også gjennom en lang rekke enkeltaktører. Innenfor velferdsapparatet fortolkes og iverksettes vedtatt politikk i et system der det ofte er knapphet både på tid og ressurser, der det ikke alltid er gitt hvordan ulike politiske målsettinger skal veies opp mot hverandre, og der kunnskap om sammenheng mellom tiltak og effekter er usikker (Lipsky, 1980). Dette skaper et vedvarende behov for byråkratisk skjønnsutøvelse. Det var bakteppet for Lipskys (1980) argument om at bakkebyråkrater - de som møter brukerne av offentlige tjenester ansikt til ansikt - ikke bare iverksetter offentlig politikk, men også utformer den. ${ }^{8}$ Han skildret med dette en aktør som lå langt unna Webers idealtypiske, regelstyrte byråkrat.

Hvor omfattende byråkraters rom for skjønn er, i hvilken grad dette skjønnet lar seg regulere og hva som påvirker byråkratenes skjønnsutøvelse, er sentrale, men omstridte spørsmål innen byråkratiteori (se f.eks. Brehm \& Gates, 1999; Evans, 2010; Nothdurfter \& Hermans, 2018; Van Berkel, Caswell, Kupka, \& Larsen, 2017; Wallander \& Molander, 2014; Zacka, 2017).

Skjønnsutøvelsen preges av de organisatoriske betingelsene bakkebyråkrater arbeider under (Brodkin, 2011; van Berkel \& Knies, 2016), men også av hvilke oppfatninger de har om politikken de skal implementere (Heinesen, Winter, Bøge, \& Husted, 2004; May \& Winter, 2009), og om brukerne de skal bistå og deres behov. I sin bok, «Working, shirking and sabotage» viste Brehm og Gates (1999) at selv om byråkrater i hovedsak iverksetter vedtatt politikk, finnes det også situasjoner der de vil sabotere den av hensyn til brukerne. Særlig hvis politikken eller virkemidlene vurderes som lite etiske eller lite effektive, reduseres sjansen for at bakkebyråkratene vil iverksette dem (Diop-Christensen, 2015; Heinesen et al., 2004; May \& Winter, 2009). Norsk aktiveringspolitikk har fătt et av sine sterkeste uttrykk nettopp overfor nyankomne flyktninger og innvandrere som gjerne anses som en spesielt sårbar gruppe. Her blir dermed spørsmålet om bakkebyråkratenes skjønnsutøvelse spesielt relevant. Det blir viktig å

\footnotetext{
${ }^{8}$ Lipsky valgte betegnelsen «klient» framfor «bruker» for å betone den sterke maktasymmetrien mellom partene, spesielt innenfor det sosialpolitiske feltet Det samme argumentet om maktens asymmetri gjelder strengt tatt også i introduksjonsprogrammet, det empiriske utgangspunktet $i$ artikkel 3. Her bruker vi likevel termen «deltaker», blant annet fordi dette er et begrep som er nedfelt i loven og fordi «deltaker» signaliserer et noe større rom for medvirkning enn «klient» (Djuve \& Kavli, 2007).
} 
avdekke om forventningen om rask overgang til lønnet arbeid formidles i like stor grad til alle typer deltakere og av alle typer av bakkebyråkrater. Og det blir viktig å forstå hvilken rolle deltakernes egne holdninger og verdier spiller i møte med velferdsstatens iverksettere.

\subsection{Perspektiver på kvinners yrkesdeltakelse}

Verken neo-assimileringsteori eller segmentert assimileringsteori har viet innvandrede kvinners yrkesdeltakelse oppmerksomhet ut over å konstatere det åpenbare: kvinner har lønnet arbeid i mindre grad enn menn. Vi må dermed til annen litteratur for å lete etter svar på hvorfor det er slik, og hva som kan forklare variasjoner i kvinners yrkesdeltakelse. På mikronivå finnes to tilnærminger: mikroøkonomiske teorier knyttet til kost-nytte-maksimering og verdibaserte teorier om normative føringer for individers atferd. Innenfor de mikroøkonomiske tilnærmingene forstås kvinners yrkesdeltakelse som et produkt av en strategi for å maksimere nytte. Lønner det seg (for familien) at hun er hjemme og tar seg av oppgavene der, eller er det mer lønnsomt om hun skaffer seg en jobb? Forskjeller i menns og kvinners yrkesdeltakelse relateres her gjerne til kjønnsspesifikk spesialisering (Nakamura \& Nakamura, 1992) og forskjeller i humankapital (Becker, 1964/1993). I samfunn der menn har høyere inntekt enn kvinner, vil kvinners yrkesdeltakelse reduseres når familien får barn, men i mindre grad dersom kvinnen har investert i høyere utdanning. Et premiss i mye av denne litteraturen er at kvinners arbeid implisitt vurderes som et «nødvendig onde», og at yrkesdeltakelsen derfor vil reduseres når alternative kilder til livsopphold øker (Steiber \& Haas, 2012). Dette premisset har sine røtter i en debatt som oppstod i kjølvannet av den industrielle revolusjon. Kvinner hadde selvsagt arbeidet også tidligere, men forflytningen av arbeidet fra hjemmet til fabrikkene bidro til at kvinners lønnsarbeid ble definert som et problem og som noe naturstridig (Scott, 1993:399). Vi kan fortsatt finne rester av denne motsetningen mellom lønnet arbeid og kvinnelighet $\mathrm{i}$ tenkningen rundt kvinners forhold til lønnsarbeid. Ellingsæter (2017:143) illustrerer at det finnes en kjønnsdualistisk tenkning også i vår tids debatt, der familieforhold får en større plass i forståelsen av kvinners yrkesdeltakelse, enn forholdene i arbeidsmarkedet.

Logikken i de mikroøkonomiske teoriene om allokering av tid har også blitt brukt til å utvikle hypoteser om sammenhengene mellom velferdsregimer, familiepolitikk og kvinners yrkesdeltakelse. Ulike regimer produserer velferd gjennom ulike kombinasjoner av stat, marked og familie. Der en godt utbygd velferdsstat vil gjøre innbyggerne mindre avhengige av markedet og familien, vil en mindre utviklet velferdsstat oftere overlate individene til markedet eller familien. I sin typologi over velferdsregimer brukte Esping-Andersen (1990) begrepet dekommodifisering for å beskrive stater som reduserte individers avhengighet av markedet i situasjoner der de ikke kunne forsørge seg selv gjennom lønnet arbeid. Typologien tok imidlertid ikke hensyn til at kvinner i mindre grad enn menn er kommodifisert - altså avhengige av markedet - men i større grad er økonomisk avhengige av familien (se f.eks. Lewis, 1992; Lister, 1990; Orloff, 1993). Begrepet defamilisering ble introdusert som et mål på i hvilken grad individer sikres en akseptabel levestandard gjennom overføringer og/eller lønnsarbeid, 
uavhengig av familie (Lister, 1994). Her rangeres de sosialdemokratiske velferdsregimene høyt, med sine velutviklede tjenestetilbud og overføringer, ikke minst til barnefamiliene (EspingAndersen, 2009). Samtidig er det nettopp i forbindelse med sosiale ordninger og overføringer til småbarnsfamiliene at debattene går høyt, rundt de insentiveffektene det kan ha for familier med lave inntjeningsmuligheter i arbeidsmarkedet.

I likhet med de mikroøkonomiske teoriene handler også de verdibaserte teoriene om kvinners motivasjon for å ta lønnet arbeid. Her knyttes imidlertid motivasjon til preferanser og normer, mer enn til hva som lønner seg økonomisk. Dette perspektivet fikk et oppsving med Hakims (1991, 2000) preferanseteori. Hun tar utgangspunkt i det tilsynelatende paradoksale i at deltidsarbeidende kvinner i jobber med lav status og dårlig lønn sier de er fornøyd med jobbene sine. Grunnen er, ifølge Hakim, at de vurderer arbeidet etter hvor familievennlig det er, ikke etter lønn eller status. Hun deler kvinner inn i tre typer: familieorienterte, arbeidsorienterte eller adaptive (Hakim, 2006:288-289). De familieorienterte foretrekker å ikke ha lønnet arbeid (dersom økonomien tillater det) og bruker utdanningen sin primært som kulturell kapital. Antall barn påvirkes i stor grad av landets familiepolitikk, men i liten grad av arbeidsmarkedspolitikken. De arbeidsorienterte har yrkeslivet som hovedprioritet og påvirkes i større grad av økonomisk politikk og forhold i arbeidslivet, enn av familiepolitikk. De adaptive ønsker å kombinere arbeid og familie, eller er usikre på hva de vil. De er svært mottakelige for insentivstrukturer i offentlig politikk.

Hakim (2006) hevder altså at både kjønnsforskjellene og kvinneforskjellene i yrkesdeltakelse i moderne, velstående samfunn handler mer om kvinners preferanser enn om de strukturene de er omgitt av. Teorien har blitt kritisert for å undervurdere hva strukturelle føringer betyr for kvinners yrkesdeltakelse (Crompton \& Harris, 1998a; Gash, 2008b; Halrynjo \& Lyng, 2009; Kangas \& Rostgaard, 2007; McRae, 2003). Kritikken har blant annet vært knyttet til premisset om at kvinner og menn har like muligheter i arbeidslivet, og at kvinners overrepresentasjon i dårlig lønnede jobber handler mer om preferanser enn om makt og mulighet. Kvinners (og menns) preferanser former valgene deres, de avgjør dem ikke, skriver Crompton og Harris (1998b:132). Argumentet støttes blant annet av at preferanser om arbeid og arbeidstid varierer systematisk mellom land og dermed trolig må forstås i lys av den samfunnsmessige konteksten de inngår i (Stier \& Lewin-Epstein, 2003; Wielers, Münderlein, \& Koster, 2013). Hakims teori om at kvinner har ulike «typiske» orienteringer, forutsetter at preferanser etableres tidlig i livet og deretter endres lite. Heller ikke dette premisset er selvsagt, slik jeg tidligere har diskutert med utgangspunkt i sosialpsykologiens debatter om kognitiv dissonans. Premisset om at kvinner tilpasser praksis slik at det er i tråd med preferansene, har også møtt kritikk. Flere studier finner at kvinner, også over tid, har en praksis knyttet til sysselsetting som er i konflikt med de holdninger og verdier de gir uttrykk for (Crompton, Brockmann, \& Lyonette, 2005; Gash, 2008b). En sentralt spørsmål blir dermed hvordan vi skal tolke en slik dissonans. Handler det om manglende muligheter til å realisere preferansene sine, eller om at preferansene uttrykker en mer generell tilslutning til et ideal om familieorganisering, mer enn et detaljert program for hvordan livet skal leves? 
Mitt utgangspunkt er at både mikroøkonomiske og kultur- og verdibaserte perspektiver har verdi i analyser av innvandrede kvinners yrkesdeltakelse. I den norske konteksten med relativt sjenerøse velferdsordninger og høye kompetansekrav i arbeidslivet, retter de mikroøkonomiske perspektivene søkelyset mot spørsmålet om det lønner seg for innvandrede kvinner å ta lønnet arbeid utenfor hjemmet. Og de kultur- og verdibaserte perspektivene styrer oppmerksomheten mot behov for å kartlegge innvandreres holdninger til yrkesdeltakelse, og til relasjonen mellom disse holdningene og kvinners faktiske yrkesdeltakelse. Steiber og Haas (2012:9) påpeker samtidig at både de mikroøkonomiske og de kultur- og verdibaserte teoriene har tatt for lite hensyn til at de samme organisatoriske strukturene, for eksempel i familiepolitikken, kan ha ulik effekt for ulike grupper av kvinner og i ulike typer av familier. Det er ikke gitt at en samfunnsmodell som er utviklet med tanke på å dekke behovssituasjoner i majoritetsbefolkningen, virker på samme måte blant innvandrere og deres etterkommere. 


\section{Forskningsdesign, data og metode}

Et forskningsdesign bør være fleksibelt nok til å ta høyde for både hva som skal studeres og hvilken kontekst studien skjer innenfor (Seale, Gobo, Gubrium, \& Silverman, 2004:7). Min avhandling bygger på en kombinasjon av kvantitative og kvalitative data og metoder. Det er to grunner for dette. For det første krever spørsmålene ulike data for å besvares. Jeg har både vært opptatt av spørsmål om fenomeners omfang og utbredelse, og av hvordan ulike aktører reflekterer rundt sine holdninger og handlinger. For det andre har kombinasjonen av metoder gjort det lettere for meg å bli bevisst på betydningen av mitt ståsted, mine erfaringer og mine verdier under etableringen og fortolkningen av dataene. Forskere bør tilstrebe en sensitivitet for de perspektivene aktører med ulike ståsteder kan bringe inn. En forsker trenger likevel ikke selv være en del av den gruppen han eller hun vil studere for å ta innover seg denne gruppens situasjon eller ståsted (Harding, 2016). Marx skrev overbevisende om proletariatet uten selv å være en del av det, og da Ibsen lot Nora marsjere ut døren tredje juledags morgen, skapte han et av verdenslitteraturens mest kjønnspolitiske øyeblikk, uten selv å være verken skilt eller kvinne. I dette kapitlet gjør jeg rede for hvordan dataene er etablert og hvilke strategier som ble brukt for å øke dataenes kvalitet. Å gjennomføre spørreundersøkelser og kvalitative intervjuer blant innvandrere reiser ekstra utfordringer, og dette vies spesiell oppmerksomhet.

\subsection{Etablering av data}

Artiklene bygger på:

1. Surveyundersøkelse blant 1821 personer fra Iran, Irak, Norge, Pakistan og Vietnam (2009).

2. Kvalitative intervjuer og fokusgrupper med byråkrater og brukere i introduksjonsprogram for nyankomne flyktninger og innvandrere $(2007,2011)$.

3. Registerdata, kvinner i lønnet arbeid fra Iran, Irak, Norge, Pakistan, Somalia og Vietnam (2009-2013).

\section{Telefonbasert surveyundersøkelse}

Formålet med surveyundersøkelsen var å gi en bred beskrivelse av holdninger og praksis knyttet til organiseringen av familieliv blant utvalgte grupper av innvandrere og etterkommere. Ambisjonen var både å beskrive mangfoldet av familiepraksiser i dagens Norge og å kartlegge omfanget av praksisene i ulike landgrupper. Surveyen ble gjennomført på oppdrag fra Barne-, likestillings- og inkluderingsdepartementet, og er nærmere beskrevet i Kavli og Nadim (2009), der også hovedtendensene i materialet rapporteres og drøftes. 


\section{Utvalg}

Spørreundersøkelsen omfatter 1821 personer (20-55 år) bosatt i Norge. Alderssnittet ble valgt for å treffe personer i en fase av livet der etablering og organisering av (egen) familie skulle være nært i tid. Det ble trukket seks underutvalg. Ett blant personer uten innvandringsbakgrunn, og fire blant personer som var født enten i Iran, Irak, Vietnam, Pakistan. I tillegg ble samtlige pakistanske etterkommere over 20 år invitert til å delta i undersøkelsen. Utvalgene ble trukket med en jevn fordeling av kvinner og menn i alle seks underutvalg. Valget av landgrupper balanserer tre hensyn: de måtte være av en viss størrelse, inkludere minst en landgruppe der antall etterkommere over 20 år var stort nok til å innlemmes i en survey, og samlet sett representere et mangfold med hensyn til forhold som vi antok kunne påvirke organiseringen av familielivet i Norge. Innvandrerne som inngår i undersøkelsen er blant de ti største gruppene av innvandrere i Norge og bestod på undersøkelsestidspunktet av til sammen 90000 personer. Pakistanske etterkommere var den eneste gruppen der mange nok hadde nådd en alder der de hadde rukket å etablere egen familie. Gruppene er ulike i familiestørrelse, yrkesaktivitet, religion og utdanningsnivå.

\section{Gjennomføring og frafallsanalyse}

Utvalget ble trukket fra Folkeregisteret og var representativt for befolkningen, gitt nevnte spesifikasjoner. Frafall kan likevel gi systematiske skjevheter. Undersøkelsen ble gjennomført per telefon, og manglende telefonnummer kan ha gitt skjevheter i materialet. Det er rimelig å anta at personer med en stabil tilknytning til Norge (lang botid, familie, deltakelse i arbeid eller utdanning) i større grad har et registrert telefonnummer enn personer med en løsere tilknytning. For å gjøre (det øvrige) frafallet så lavt som mulig, ble intervjuer gjennomført på deltakernes morsmål, det ble benyttet en ekstra lang feltperiode (18 uker) for å ta hensyn til at en del oppholder seg perioder i utlandet, det ble foretatt flere kontaktforsøk enn det som er vanlig, deltakere fikk tilbud om skriftlig informasjon dersom de var usikre på deltakelse, og det ble lagt til rette for å gjøre intervjuer både på dag- og kveldstid. Opplegget for undersøkelsen ble vurdert og godkjent av Norsk samfunnsvitenskapelig datatjeneste (nå Norsk senter for forskningsdata).

Svarprosenten varierer mellom 30 prosent i det irakiske utvalget og 50 prosent blant norskfødte med pakistanske foreldre (tabell 4.1). Mens nekting (lav svartilbøyelighet) er den viktigste årsaken til frafall i surveyer i majoritetsbefolkningen, er det blant innvandrere en større utfordring å komme i kontakt med informantene (Feskens, Hox, Lensvelt-Mulders, \& Schmeets, 2007; Holmøy \& Wiggen, 2017; Myrberg, 2013). Svartilbøyeligheten - altså andel av dem vi fikk kontakt med som deltok - varierer fra 50 til 70 prosent.

Personer med lav/«uoppgitt» utdanning og uten lønnet arbeid er noe underrepresentert i utvalget (tabell 4.2). Unge (20-29 år) er noe underrepresentert blant innvandrere og blant pakistanske etterkommere, mens de er overrepresentert blant personer uten innvandringsbakgrunn. Siden unge har en mer kjønnslikestilt profil enn eldre, tilsier dette at vi blant innvandrere og etterkommere kunne komme til å undervurdere forekomsten av 
kjønnslikestilte holdninger, mens det motsatte vil være tilfellet blant personer uten innvandringsbakgrunn.

Tabell 4.1: Frafallsregistrering, intervjuundersøkelse. Kilde: Synovate Norge/Fafo.

\begin{tabular}{lcccccc} 
& $\begin{array}{c}\text { Nummersatt } \\
\text { utvalg }\end{array}$ & $\begin{array}{c}\text { Antall } \\
\text { intervju }\end{array}$ & $\begin{array}{c}\text { Antall } \\
\text { nekt }\end{array}$ & $\begin{array}{c}\text { Antall } \\
\text { ikke svar }\end{array}$ & $\begin{array}{c}\text { Svar } \\
\text { prosent }\end{array}$ & \begin{tabular}{c} 
Svartilbøyelighet \\
\hline Irak
\end{tabular} \\
Iran & 826 & 300 & 208 & 492 & $30 \%$ & $59 \%$ \\
Pakistan & 312 & 131 & 383 & $38 \%$ & $70 \%$ \\
Pakistan, etterkommer & 501 & 300 & 206 & 295 & $37 \%$ & $59 \%$ \\
Vietnam & 914 & 300 & 305 & 309 & $33 \%$ & $50 \%$ \\
Norge & 795 & 300 & 253 & 242 & $38 \%$ & $54 \%$ \\
\hline Total & 4933 & 1812 & 1232 & 1889 & $37 \%$ & $60 \%$ \\
\hline
\end{tabular}

Dersom enkelte grupper er skjevt representert i et utvalg, kan statistisk vekting vurderes. For at vekting skal gi mening, må det både være en betydelig skjevhet i materialet og en sterk sammenheng mellom det vi ønsker å undersøke, for eksempel holdning til mødres yrkesdeltakelse, og den variabelen som er skjevt representert $\mathrm{i}$ utvalget, for eksempel alder (Hellevik, 1991, 2015). Dette var i liten grad tilfelle. 41,9 prosent av innvandrerne fra Iran og 10,5 prosent av innvandrerne fra Pakistan i utvalget svarer at de er positive til mødres yrkesdeltakelse i småbarnsfasen. Vektet etter alder, øker andelen til 42,7 prosent blant iranere og 11,8 prosent blant pakistanere, altså en marginal økning på henholdsvis 0,8 og 1,3 prosentpoeng. Selv med en relativt stor skjevhet i utvalget, har vektingen dermed lite å si for utfallet på en av de sentrale, avhengige variablene. Vekting er også omstridt fordi det forutsetter at sammenhengene mellom vektevariabelen og det som skal måles blant de som har deltatt i undersøkelsen, også er til stede blant de som ikke er blitt intervjuet. Slik er det ikke nødvendigvis. Jeg har derfor ikke vektet nettoutvalget, men understreker de nevnte skjevhetene i materialet, og har dette in mente dersom resultatene kan tenkes å skyldes denne skjevheten.

Tabell 4.2: $\quad$ Over-og underrepresentasjon av ulike grupper i utvalget. Andel i ulike grupper $i$ utvalget fratrukket andel i befolkningen. Kilde: Kavli og Nadim 2009:152.

\begin{tabular}{lcccccc} 
& Norge & Iran & Irak & Vietnam & Pakistan & Pakistan etterkommere \\
\hline Kvinner & 2 & 1 & 6 & -7 & -2 & -2 \\
$20-29$ år & 4 & -12 & -8 & -9 & -8 & -11 \\
$30-39$ år & 6 & -3 & -1 & -3 & 0 & 11 \\
$40-49$ år & -2 & 9 & 6 & 8 & 6 & 0 \\
$50-59$ år & -9 & 6 & 3 & 4 & 1 & 0 \\
I arbeid & 4 & 4 & 0 & 7 & 12 & 4 \\
Grunnskole & -6 & -3 & -3 & -2 & 3 & -3 \\
Videregående opplæring & -3 & 0 & 4 & 7 & 0 & 0 \\
Kort høyere utdanning & 8 & -1 & 4 & 2 & 6 & 0 \\
Lang høyere utdanning & 2 & 5 & 2 & -1 & 2 & -3 \\
Uoppgitt utdanning & 0 & -2 & -7 & -6 & -10 & 0 \\
\hline
\end{tabular}




\section{Datas kvalitet}

Målefeil oppstår i større eller mindre grad i alle surveyer. I undersøkelser rettet mot innvandrere oppstår like fullt ekstra utfordringer med å oversette spørreskjemaet og rekruttere og lære opp tospråklige intervjuere, ulik kjennskap til og forståelse av begreper og institusjoner, og kulturforskjeller i tilbøyeligheten til å benytte ytterpunktene på en svarskala (Djuve, Gulløy, Kavli, \& Berglund, 2009: 49-50). Det ble derfor investert betydelige ressurser i å gjennomføre undersøkelsen på en måte som ville redusere disse utfordringene. Spørreskjemaet ble oversatt til vietnamesisk, arabisk, persisk og urdu, og intervjuene foregikk på det språket informanten foretrakk. Dette reduserer risikoen for systematisk frafall blant personer med dårlige norskferdigheter, og øker sannsynligheten for at spørsmålene blir forstått på samme vis (Deding, Fridberg, \& Jakobsen, 2008; Djuve et al., 2009; Lipps, 2019). Språklig tilrettelegging er spesielt viktig for å redusere risikoen for en skjev rekruttering av kvinner, som i snitt har dårligere norskferdigheter enn menn, selv etter mange år i Norge (Vrålstad \& Wiggen, 2017).

Intervjuerne deltok på oppstarts- og avslutningsseminar med forskerne og førte logg over refleksjoner og spørsmål underveis. Dette bidro til å rette opp uklarheter i spørsmålsformuleringer og i oversettelsen av spørreskjemaet, samt til å moderere fortolkningen av enkelte spørsmål. Samtidig innebærer surveyer alltid en risiko for at selv likt formulerte spørsmål tolkes ulikt. Dette har vist seg å være en spesiell utfordring i spørsmål om holdninger og verdier (Djuve et al., 2009). Vi gjennomførte derfor fire fokusgrupper (à 3 timer), samt to individuelle intervjuer (1 og 1,5 time) for å gå mer i dybden av spørsmål som var knyttet til holdninger og verdier. Deltakerne ble gruppert etter kjønn og etter landbakgrunn (Pakistan, Norge). Personer med pakistansk bakgrunn framstår som en av de mest tradisjonelt orienterte gruppene i Norge (Kavli \& Nadim, 2009). Samtidig er perioden med små barn en familiefase som ofte kjennetegnes av en tradisjonell arbeidsdeling mellom foreldrene også $\mathrm{i}$ majoritetsbefolkningen (Baxter, Buchler, Perales, \& Western, 2015; Kitterød, 2004). Ved å begrense intervjuene til småbarnsforeldre, var hensikten å tilstrebe større sammenliknbarhet på tvers av landgruppene. Deltakerne drøftet hovedfunn fra surveyundersøkelsen og bidro med viktige refleksjoner til analysen.

Det er nå 10 år siden surveyundersøkelsen ble gjennomført. Ved gjentakelse av tverrsnittsundersøkelser er det vanlig at frekvensfordelinger endrer seg noe, mens svarmønstrene og sammenhengene som observeres er mer stabile. Basert på dette, er det grunn til å tro at vi ville finne tilsvarende forskjeller mellom landgruppene i dag, men at prosentvise fordelinger kan ha endret seg. En rimelig antakelse er at praksis i så fall vil ha endret seg i større grad enn holdninger, som normalt er mer robuste i møte med «ytre endringer». Hvis det har skjedd vesentlige endringer innenfor landgruppene de siste 10 årene, kan det ha to årsaker: at de som allerede bor i Norge har endret holdninger og/eller praksis, eller at det er kommet nye innvandrere som skiller seg fra de som allerede er bosatt. I det siste tilfellet er det grunn til å være spesielt oppmerksom på landgrupper som i snitt har kort botid. I det første tilfellet kan endring være et produkt av ytre påvirkning, for eksempel en sterkere iverksetting av arbeidslinja overfor innvandrede kvinner. Det kan imidlertid også skje gjennom en variant av generasjonsendring. Som jeg kommer tilbake til i avslutningen, kan den første generasjonen av 
pakistanske etterkommere som er i min studie, skille seg fra de som er blitt «voksne» i årene etterpå. Dette er viktige forbehold. Som det vil framgå av artiklene, bygges konklusjonene i hovedsak likevel på hoveddimensjoner i svarmønstrene, og ikke på enkeltstående frekvensfordelinger.

\section{Kvalitative intervjuer og fokusgrupper med byråkrater og brukere}

Nyankomne flyktninger og deres familier møter den norske, institusjonelle konteksten første gang innenfor rammen av introduksjonsprogrammet. I henhold til introduksjonsloven skal deltakerne involveres i å utforme sin individuelle (opplærings)plan (introduksjonsloven, paragraf 6, fjerde ledd). Formålet med å ta i bruk kvalitative intervjuer og fokusgrupper var å få innsikt i hva disse møtene inneholder, hvordan de arter seg i praksis og hvorfor utfallet blir som det blir. På hvilken måte og i hvilken grad kommuniserer deltakerne hva de ønsker? Og hvordan håndterer programrådgivere og lærere situasjoner der det enten er vanskelig å få innsikt i hva deltakerne ønsker, eller når de ønsker noe som bakkebyråkratene ikke kan, eller vil, tilby?

\section{Utvalg og gjennomføring}

Materialet omfatter dybdeintervjuer og fokusgrupper med lærere, programrådgivere og programdeltakere. De er i hovedsak samlet inn i forbindelse med to av Fafos evalueringer av introduksjonsprogrammet. Evalueringene ble gjennomført i 2007 og i 2011 på oppdrag fra henholdsvis Barne-, likestillings- og inkluderingsdepartementet og IMDi. ${ }^{9}$ Datainnsamlingen er beskrevet både i rapportene og i artikkelen, så gjennomgangen her er ment å supplere disse. Feltarbeidet ble gjennomført i 18 kommuner. Tre forskere delte på oppgaven og tilbrakte en til to dager i hver kommune. Materialet omfatter intervjuer eller fokusgrupper med 54 programveiledere, 37 norsklærere og 34 deltakere i introduksjonsprogrammet for nyankomne flyktninger. I tillegg benyttes en surveyundersøkelse blant 320 programrådgivere i introduksjonsprogrammet (svarprosent 84), først og fremst for å gi et inntrykk av hvor utbredt ulike strategier for brukermedvirkning kan være blant ansatte i integreringsapparatets førstelinje.

I kartleggingen av kommunenes introduksjonsarbeid ble det benyttet en kombinasjon av delvis strukturerte, individuelle intervjuer og gruppesamtaler med vignetter. Det ble også gjennomført intervjuer med andre aktører i det lokale integreringsarbeidet. Disse berørte ikke forskningsspørsmålene i artikkelen direkte, men var viktige fordi de ga større innsikt i de strukturelle rammene for introduksjonsarbeid i kommunen. Deltakerne vi intervjuet, var i hovedsak kvinner og hadde bakgrunn fra Somalia, Irak, Afghanistan, Eritrea, Myanmar og Syria. I rekrutteringen la vi vekt på en spredning i alder, antall barn, familietype, botid i Norge og hvor lenge de hadde deltatt i introduksjonsprogrammet - dette for å få en bredde i erfaringer og perspektiver. Intervjuene varte mellom 30 og 80 minutter.

\footnotetext{
${ }^{9}$ Kavli et al. 2007; Djuve et al. 2011.
} 


\section{Datas kvalitet}

Kvalitative intervjuer og fokusgrupper gir mulighet til å utforske ambivalens, motsetninger og variasjon i materialet. For å sette informantenes vurderinger og beslutninger inn i en sammenheng, har det også vært nødvendig med innsikt både i nasjonale og lokale rammer for integreringsarbeidet. Her var det en fordel at både jeg og de øvrige to forskerne som var involvert i datainnsamlingen, hadde bred erfaring med å studere norske kommuners introduksjonsarbeid og kunne tilbringe tid i kommunen også utover selve intervjuet. Det kan likevel være krevende for en utenforstående å gripe kompleksiteten i vurderingene ansatte i integreringsapparatets førstelinje gjør, og stille de avgjørende spørsmålene. I intervjuene av de ansatte valgte vi derfor en kombinasjon av individuelle intervjuer og gruppesamtaler. I de individuelle intervjuene var det større rom for den enkeltes personlige vurderinger og erfaringer - også erfaringer som ikke er like lette å dele med kollegaer. I gruppesamtaler ønsket vi å åpne for større kollegial refleksjon. Utgangspunktet for samtalene var tre vignetter med beskrivelser av deltakere med ulike egenskaper og ambisjoner for livet i Norge. Metoden er blant annet egnet til å få innsikt i holdninger, som gjerne blir tydeligere når de konfronteres med andres (Lewis \& Nicholls, 2013:56). Vignettene ga dessuten deltakerne i fokusgruppene større frihet til å drøfte alternative tilnærminger enn dersom de skulle brukt konkrete eksempler fra deltakere de selv arbeidet med. Gjennom diskusjonene utfordret informantene hverandre på en annen måte enn det vi som utenforstående kunne gjøre. Gjennom diskusjonene i

gruppesamtalene kom ambivalens og motsetninger fram rundt hvordan deltakere, med ulike ønsker og ulik måte å formidle disse ønskene på, kunne eller burde bli møtt. For å legge til rette for en mest mulig likeverdig og åpen diskusjon, ble gruppene satt sammen av ansatte på samme eller liknede stillingsnivå.

De kvalitative intervjuene med deltakere i introduksjonsprogrammet kunne være sensitive og ble derfor gjennomført individuelt. Tolk var tilgjengelig, men noen ønsket å gjennomføre intervjuet uten. Tolken kan påvirke kommunikasjonen mellom forsker og informant både gjennom oversettelsen av de spørsmålene forskeren stiller og gjennom oversettelsen av de svarene informanten gir. Også ikke-verbal kommunikasjon som ansiktsuttrykk, blikk og tonefall er en viktig kontekstuell ramme for å fortolke det som blir sagt under intervjuet. Selv om forskeren kan observere informanten under hele intervjuet, kan en del av den ikke-verbale kommunikasjonen bli vanskeligere å forstå med den forsinkelsen som tolkingen medfører. Tolken kan i noen tilfeller også ikle seg rollen som «portvokter» og sensurere dersom informanten sier noe tolken mener kan gi forskeren et uheldig inntrykk av den landgruppen informanten og tolken begge tilhører (Williamson et al., 2011:383). En tilnærming til disse utfordringene er å forsøke å oppnå en konseptuell ekvivalens - altså en situasjon der både intervjuerens og informantens formuleringer oversettes så direkte som mulig, og der tolken verken utbroderer eller utelater noe av det som blir sagt (Williamson et al., 2011:384). Vi brukte sertifiserte tolker gjennom de kommunale tolketjenestene. Overfor enkelte tolker var det likevel nødvendig å presisere at vi forventet direkte tolking. Tolkeassisterte intervjuer reiser epistemologiske spørsmål om hvilken kunnskap som er tilgjengelig gjennom kvalitative intervjuer, og i hvilken grad bruk av tolk bryter med forutsetningene for et godt intervju. Etter mitt syn må også de etiske problemene ved alternativet vurderes: at vi uten bruk av tolk går 
glipp av perspektiver og erfaringer fra en stor og uorganisert (i betydning: nyankomne innvandrere mangler formelle talspersoner) gruppe brukere.

Intervjuene ble gjennomført for om lag 7 og 12 år siden. Siden den gang kan arbeidsrettingen av integreringsarbeidet ha blitt mer uttalt og sterkere implementert også ute i kommunene. Jeg skal derfor være forsiktig med å si noe om hvor vanlige de typene utfall vi beskriver, er i dag. Det er likevel liten grunn til å tro at det ikke fortsatt oppstår situasjoner der deltakernes preferanser helt eller delvis kommer i konflikt med programmets målsettinger, og der bakkebyråkrater må utøve skjønn for å balansere ulike hensyn. På dette området har dataenes alder trolig mindre betydning.

\section{Administrative registerdata på individnivå}

Jeg har brukt to ulike sett av administrative registerdata. For det første ble registerdata brukt for å støtte opp under surveyundersøkelsen. Å gjennomføre lange personlige intervjuer er kostbart, og risikoen for intervjutretthet og frafall øker med intervjuets lengde. En del informasjon om informantene, deres ektefeller og eventuelle barn ble derfor innhentet gjennom registerdata, slik at intervjutiden kunne holdes nede. I tillegg ble registerdataene benyttet til en frafallsanalyse (se over). For det andre ønsket jeg å flytte søkelyset fra holdninger til praksis. I avhandlingens andre artikkel brukte jeg derfor registerdata for årene 2009 til $2013^{10}$. I disse dataene finnes detaljert informasjon om arbeidsforhold i tillegg til omfattende demografiske data, og materialet er tilrettelagt slik at det er mulig å følge deltakelse i arbeidslivet over tid. Uttrekket er avgrenset til kvinner, og omfatter alle arbeidstakere uten innvandringsbakgrunn, samt alle arbeidstakere som hadde innvandret til Norge fra Iran, Irak, Pakistan, Vietnam eller Somalia og som var sysselsatt 1 . november i 2009. Aldersavgrensning ble satt til 25-54 år, og studenter i deltidsarbeid og personer med mer enn én stilling ble ikke tatt med. Dataene og avgrensningene er beskrevet og begrunnet nærmere i artikkel 2. Jobbmulighetene for innvandrere kan være spesielt følsomme for økninger i ledigheten (Barth, Bratsberg, \& Raaum, 2004). Dette betyr at de prosentvise endringene jeg finner i arbeidstid og arbeidstilknytning for de fem landgruppene mellom 2009 og 2013, kan se annerledes ut for innvandrere som blir bosatt under andre økonomiske konjunkturer.

\subsection{Måling av holdninger og handlinger}

Samsvar, eller mangel på samsvar, mellom holdning og handling er et viktig tema innenfor samfunnsvitenskapen både vitenskapsteoretisk og metodisk. ${ }^{11}$ Rasjonaliteten kan svikte fordi vi sjelden har helt klare preferanser, men også fordi vi ubevisst kan tilpasse preferansene våre til

\footnotetext{
10 Registerdataene ble gjort tilgjengelig gjennom prosjektet: Work-Life Challenges - Norges forskningsråd, prosjekt (202647/S20).

${ }^{11}$ Se også diskusjoner i kapittel 3.1
} 
hva vi tror vi kan oppnå (Elster, 1989). I metodelitteraturen anbefales det derfor at man unngår å stille spørsmål i surveyer om folks holdninger, uten samtidig å følge opp med spørsmål om faktisk atferd (Mordal, 1989:39-42). Samtidig kan svarene vi får om faktisk atferd være upresise, spesielt dersom de berører normative tema. For eksempel besvarer noen par spørsmål om arbeidsdeling på en slik måte at de skal framstå som mer likestilte enn de faktisk er (Kitterød, 2004). Fenomenet ble beskrevet av Haavind allerede 1984 som «kvinnens nye byrde», idet hun fant at en del kvinner overdrev mannens innsats hjemme i et forsøk på å framstå som mer likestilt utad.

Hvilken betydning «blikket utenfra» kan ha hatt i vår studie, er krevende å vurdere. For hvem er i så fall «de andre» som deltakerne i undersøkelsen opplever å bli vurdert av, og i hvilken retning kan det ha påvirket svarene? Basert på de relativt store variasjonene som framkommer mellom landgrupper i surveymaterialet, på diskusjonene i fokusgruppene og på kommunikasjonen med intervjuerstaben, er mitt inntrykk at strategisk svaring var lite utbredt. I de tilfellene strategisk svaring ble tematisert, enten i fokusgruppene eller fra intervjuerne, handlet det oftest om en bekymring for hvordan svarene kunne bidra til å skape et (enda) mer negativt bilde av innvandrere i Norge, og at verken forskere eller norsk offentlighet uansett ville forstå hvorfor man organiserte seg som man gjorde (Kavli, 2012; Kavli \& Nadim, 2009). Dette kan ha gitt en overrapportering av likestilte holdninger og praksiser, både fordi de med lavest tillit ville være mer tilbøyelige til å ikke delta i undersøkelsen, og fordi en del av de som deltok kan ha ønsket å formidle et bilde av innvandrere som norsk offentlighet vil tolke som positivt. På den andre siden kan det også tenkes at noen var bekymret for å framstå som for norske og derfor rapporterte en mindre likestilt praksis enn det som var tilfelle i deres familie. Bruken av morsmålsintervjuere og opplevelsen av å snakke med «en av oss» kan eventuelt ha trukket i en slik retning.

At holdninger ikke alltid sammenfaller med atferd, har ledet flere til å konkludere med at holdningsspørsmål har lav validitet (Smelser, 1998). Levine (1985) hevder imidlertid at motstridende holdninger kan ha interesse i kraft av seg selv, på tross av at de ikke predikerer atferd. Holdningene som måles trenger strengt tatt ikke å være «sanne» i den forstand at de er uttrykk for reelle holdninger eller verdier. Hvis holdningene som måles varierer systematisk mellom ulike grupper, er de både «sanne» og potensielt nyttige i den forstand at de fanger opp reelle forskjeller mellom ulike grupper. Og som artikkel 1 og 4 illustrerer, viser surveymaterialet betydelige forskjeller både i holdninger og praksis mellom ulike landgrupper. For å forstå forskjellene er det likevel viktig at analysen kan støtte seg på ulike data fra ulike kilder. Under datainnsamlingen har jeg så langt som mulig ivaretatt hensynet til utfordringene gjennom å kartlegge både holdninger og praksis, gjennom å benytte vel utprøvde spørsmålsbatterier, gjennom grundig testing av spørsmålenes oversettelse til ulike språk, gjennom opplæringen og oppfølgingen av intervjuerne og gjennom bruken av fokusgrupper for - blant annet - å drøfte hva som kan ligge bak de kvantitative mønstrene i surveydataene. 


\subsection{Etiske betraktninger}

Den nasjonale forskningsetiske komité for samfunnsvitenskap og humaniora (NESH) har utarbeidet et sett av forskningsetiske retningslinjer. Her vil jeg kort diskutere to sett av utfordringer som har vært viktige i etableringen og bruken av mitt materiale. Data er etablert gjennom ulike prosjekter, vurdert og godkjent av Norsk samfunnsvitenskapelig datatjeneste (NSD). ${ }^{12}$

\section{Informert og fritt samtykke}

Personer som lar seg intervjue, skal være informert om hva som er hensikten med undersøkelsen, og selv avgjøre om de ønsker å delta. Både i kvantitative og i kvalitative intervjuer forutsetter dette at informasjonen gis på et språk informanten forstår. I surveyundersøkelsen brukte vi oversatt informasjonsmateriell og morsmålsintervjuere. Utvalget fikk informasjon om spørreundersøkelsen i tråd med anbefalingene som er utarbeidet av Personvernombudet for forskning ved NSD, og avgjorde deretter om de ønsket å delta eller ikke. Terskelen for å nekte å delta i telefonbaserte intervjuundersøkelser er generelt lav, og det er liten grunn til å tro at noen har følt seg presset.

Intervjuene av flyktninger reiste andre forskningsetiske utfordringer. Intervjuene foregikk i kommunens lokaler, og første gangs kontakt skjedde via ansatte i introduksjonsprogrammet. Mange av programdeltakerne hadde lav utdanning, noen var funksjonelle analfabeter, og å sende skriftlige forespørsler om deltakelse vil ha gitt et svært skjevt utvalg. Ved å etablere kontakt via programmet, fikk flyktningene mulighet til å stille spørsmål og få svar umiddelbart, og vi kunne redusere unødig bekymring knyttet til formelt utseende brev. Ulempen ved en slik framgangsmåte er at grensene mellom forskere og kommunalt ansatte blir utydelige. Vi har ikke grunn til å tro at programrådgivere utøvet press på deltakerne for å delta, men deltakerne kan likevel ha opplevd det som vanskelig å si nei. Vi brukte derfor tid før vi startet intervjuet på å forsikre oss om at informantene var trygge på fire ting: at det var frivillig å delta, at de kunne trekke seg fra intervjuet uten begrunnelse, at de kunne nekte å svare på enkeltspørsmål, og at programrådgivere, lærere eller andre deltakere ikke ville få vite hva de hadde fortalt til oss. Etter at denne informasjonen var gitt på nytt, med tolk, spurte vi om han/hun fortsatt ville la seg intervjue. Under det feltarbeidet som ligger til grunn for artikkel 3 , trakk ingen av de oppmøtte seg, men dette har skjedd både ved tidligere og senere anledninger i liknende prosjekter. Erfaringen tilsier dermed at det er helt nødvendig å sette av tid til å repetere disse fire punktene før intervjuet kan starte - spesielt når rekrutteringen er skjedd via personer som informantene står i et avhengighetsforhold til.

\footnotetext{
12 NSD prosjektnummer 18541: Familieforhold og likestilling i ulike etniske grupper; NSD prosjektnummer 23290: Kvinner med dårlig resultat av introduksjonsprogrammet - kartlegging, analyse og forslag til tiltak; NSD-prosjektnummer 15196: Evaluering av introduksjonsordning for nyankomne innvandrere og Work Life Challenges (NFR 202647/S20 - NSD prosjektnummer for Fafo 28111).
} 


\section{Hensynet til andres livssituasjon, verdier og handlingsmotiver}

I de forskningsetiske retningslinjene heter det at «forskeren skal vise respekt for verdier og holdninger hos de som utforskes, ikke minst når disse avviker fra det som er mest vanlig $\mathrm{i}$ storsamfunnet» (NESH 2006, retningslinje 18). Enkeltpersoner eller grupper som allerede er i en utsatt posisjon, bør ikke utsettes for ytterligere belastning. Innvandrere i Norge er utsatt i den forstand at kultur, atferd og bidrag til det norske samfunnet regelmessig gjøres til gjenstand for debatt og kritikk. Dette tilsier varsomhet i valg av inndelinger og betegnelser som «kan gi grunnlag for urimelig generalisering og i praksis føre til stigma av hele samfunnsgrupper» (NESH 2006, retningslinje 22). I surveyundersøkelsen ble dette aktualisert både med spørsmålsformuleringer, utvalg og hvordan resultatene skulle presenteres. Vi valgte landgrupper med utgangspunkt i størrelse, men også ut fra foreliggende kunnskap om variasjoner i utdanning og yrkesdeltakelse. Målsettingen var at surveyen skulle gi anledning til å vise variasjoner innenfor den store gruppen av personer som har innvandret til Norge, og på den måten bidra til å illustrere ulike former for økonomisk og kulturell tilpasning. I de kvalitative analysene tilsier hensynet til informantene både varsomhet og balanse i valg av temaer, og nøkternhet i utvelgelsen av sitater fra enkeltpersoner. Flyktninger kan bære på historier som er krevende å dele. Vi stilte derfor ikke direkte spørsmål om selve flukten, om årsaken til den eller om eventuelle familiemedlemmer som fortsatt oppholdt seg i usikre områder. I en del tilfeller tok likevel informantene selv opp krevende tema, og vi satte derfor av god tid mellom intervjuene, slik at samtalen kunne forlenges ved behov og deretter rundes av forsvarlig. 


\section{Sammenfatning av artiklene}

\subsection{Verdier på vandring. Arbeidsdeling i innvandrede familier}

Hanne C. Kavli, s. 265-288 i Anne-Lise Ellingsæter og Karin Wideberg (red.) (2012):

Velferdsstatens familier. Nye sosiologiske perspektiver. Gyldendal Akademisk

I den første artikkelen er temaet kjønnslikestilling blant utvalgte grupper av innvandrere belyst gjennom arbeidsdelingen i familien. Artikkelen er deskriptiv, med en ambisjon om å gi en gjennomgang av både holdninger og praksiser rundt organiseringen av familielivet i de landgruppene undersøkelsen omfatter. Jeg beskriver hvordan ansvaret for husarbeid, omsorgsarbeid og lønnsarbeid er fordelt mellom ektefeller/samboere, og i hvilken grad denne arbeidsdelingen samsvarer med informantens holdninger til hvordan arbeidet bør fordeles. Analysen bygger på en spørreundersøkelse blant innvandrere (20-55 år) fra Pakistan, Iran, Irak og Vietnam, samt en norsk kontrollgruppe.

I artikkelen plasserer jeg landgruppene innenfor en analysemodell der holdninger og praksis ses i sammenheng. Holdninger og praksis kan sammenfalle både i form av «likestillingskonsistens» og «tradisjonell konsistens». Men de kan også være i utakt, enten gjennom «tradisjonell dissonans», der praksis er mer likestilt enn holdningene, eller «likestilt dissonans», der praksis er mindre likestilt enn holdningene. Blant informanter fra Norge og Iran beskriver et flertall en situasjon preget av likestillingskonsistens. I den grad dissonans forekommer, handler det gjerne om at informantene har en mindre likestilt praksis enn det holdningene skulle tilsi. Blant innvandrere fra Irak ligger tyngdepunktet innenfor tradisjonell konsistens, og der jeg finner dissonans, handler det i hovedsak om at praksis er mer likestilt enn holdningene. Av de landgruppene som er studert, har vietnamesere høyest forekomst av tradisjonell dissonans. Innvandrere fra Pakistan har noe mer likestilt praksis enn det holdningene skulle tilsi når det gjelder familiens forsørgelse, men rapporterer i større grad om en tradisjonell konsistens knyttet til husarbeidet.

Plasseringen av landgruppene i denne analysemodellen illustrerer hvor tyngdepunktet av informantene i hver landgruppe befinner seg. Det er likevel store variasjoner innenfor hver landgruppe. Det finnes pakistanske informanter som beskriver kjønnslikestilte holdninger og praksiser, og norske informanter uten innvandringsbakgrunn som rapporterer å leve i tråd med kjønnstradisjonelle holdninger. En betydelig andel av de innvandrede informantene rapporterer at de lever kjønnslikestilt i den forstand at de deler hus-, lønns- og omsorgsarbeid jevnt mellom seg. Samtidig framstår kognitiv dissonans som mer utbredt blant personer med kjønnstradisjonelle enn kjønnslikestilte holdninger. Avslutningsvis diskuterer jeg kort ulike måter å tolke dette mønsteret på, med vekt på samspillet mellom individuelle egenskaper og strukturelle rammer knyttet til velferdsstatens og arbeidsmarkedets organisering. 


\subsection{Integrert eller marginalisert? Innvandrede kvinner i norsk arbeidsliv}

Hanne C. Kavli \& Heidi Nicolaisen (80/20), Tidsskrift for samfunnsforskning 2016 (4):339371.

I den andre artikkelen flyttes søkelyset fra innvandreres egne beskrivelser av hvordan de organiserer familielivet, over til registerdata og hva de kan fortelle om innvandrede kvinners arbeidsdeltakelse over tid. I det offentlige ordskiftet beskrives utfordringene ofte innenfor en ramme av (manglende) økonomiske insentivstrukturer og lav motivasjon for arbeid. Det har vært mindre oppmerksomhet om hva vi kan lære av å studere innvandrede kvinner som er, eller har vært, en del av norsk arbeidsliv. Hvem har en stabil tilknytning til arbeidslivet, hvem forsvinner ut, hva kjennetegner de som går fra en deltidsjobb til en heltidsjobb, og hva kan bidra til å forklare disse bevegelsene? Analysen er av kvinner (25-54 år) som var i lønnet arbeid 1. november 2009. De følges fram til og med 2012. Kvinner som har innvandret til Norge fra Irak, Iran, Pakistan, Somalia og Vietnam, sammenliknes med kvinner uten innvandringsbakgrunn.

Vi finner noe høyere deltidsandeler blant innvandrede kvinner enn blant kvinner uten innvandringsbakgrunn. Dette lar seg i stor grad forklare av familiesituasjon, utdanning og hvilken del av arbeidslivet de er ansatt i. Når vi tar hensyn til dette, endres bildet, og kvinner fra Irak, Pakistan og Vietnam har signifikant lavere sannsynlighet for å jobbe deltid enn kvinner uten innvandringsbakgrunn. Deltidsarbeid løftes gjerne fram som en strategi for å gjøre det lettere for kvinner å kombinere lønns- og omsorgsarbeid. I et integreringsperspektiv argumenteres det også for at deltid kan være en anledning til å vise seg fram for arbeidsgiver, skaffe seg erfaring og dermed en mulighet til å etablere seg mer permanent i arbeidslivet. Artikkelen viser at for noen ser deltidsarbeid ut til å fungere som en «bro» over til heltid og, må vi anta, både sterkere økonomisk integrering og flere sosiale rettigheter. Dette gjelder særlig innvandrede kvinner med høy utdanning, og som ikke har barn eller som ikke har fătt et barn i løpet av analyseperioden. Kvinner fra Irak, Iran, Somalia og Vietnam er mer tilbøyelige til å øke arbeidstiden, enn kvinner uten innvandringsbakgrunn. Dette kan tolkes som at deltid i større grad er ufrivillig blant de innvandrede kvinnene, et funn som også finner støtte i andre undersøkelser. Ufrivillig deltid kan være relatert til hvilken del av arbeidslivet kvinnene har fătt innpass i. Innvandrede kvinner er overrepresentert i typiske deltidsbransjer, der sannsynligheten er vesentlig lavere for å øke arbeidstiden. Derimot finner vi at de som bytter jobb, i større grad også øker arbeidstiden. Dette kan bety at kvinner som bytter jobb, har en motivasjon for å øke arbeidstiden. Resultatene er i tråd med tidligere forskning, som viser at det kan være vanskelig å bryte med den typiske arbeidsorganiseringen i en bransje.

Samtidig har innvandrede kvinner en vesentlig høyere risiko for å gå ut av arbeidslivet enn kvinner uten innvandringsbakgrunn. Dette gjelder særlig kvinner med tidligere fluktbakgrunn, som somaliere og irakere, der 40 prosent av de som hadde jobb i 2009, stod uten lønnet arbeid tre år senere. Vi finner imidlertid en sammenheng mellom arbeidstidens lengde og risikoen for å gå ut av arbeidslivet. Deltid, og spesielt kort deltid, framstår som en langt mindre stabil tilknytning til arbeidslivet for innvandrede kvinner enn for kvinner uten innvandringsbakgrunn. 


\subsection{Facilitating user-involvement in activation programs: when Carers and Clerks meet Pawns and Queens}

Anne Britt Djuve \& Hanne C. Kavli (50/50), Journal of Social Policy 2015, Vol 44(2):235253.

Gjennom introduksjonsprogrammet får flyktninger og innvandrere sin første innføring i hvilke rettigheter, men også hvilke plikter, som er etablert innenfor rammen av norsk velferdsstat og arbeidsliv. En sentral ambisjon er at flest mulig, også mødre og kvinner med lite tidligere arbeidserfaring, skal orientere seg mot lønnet arbeid og delta i arbeidsrettet kvalifisering. I denne artikkelen undersøker vi hvordan brukermedvirkning iverksettes innenfor rammen av et arbeidsrettet program for flyktninger. Vi belyser de to situasjonene som er mest krevende i et medvirkningsperspektiv: når deltakeren ikke gir uttrykk for hva hun ønsker, og når deltakeren formidler ønsker som byråkraten mener ikke er forenelig med målet om en effektiv og arbeidsrettet kvalifisering. Analysen bygger på kvalitative intervjuer med 54 programrådgivere, 37 norsklærere, 34 deltakere i introduksjonsprogram og en web-basert intervjuunders $ø$ kelse blant 320 programrådgivere.

Med utgangspunkt i litteratur om bakkebyråkrati og implementering av aktiveringspolitikk, utvikler vi et analytisk rammeverk som skiller mellom to idealtyper av deltakere: «Pawns» og «Queens», og to idealtyper av bakkebyråkrater: «Carers» og «Clerks». Rammeverket anvendes i en empirisk analyse av hvordan ulike typer av bakkebyråkrater forstår og iverksetter medvirkning overfor ulike typer av deltakere. «Pawns» gir i liten grad uttrykk for holdninger og $\emptyset n s k e r$, enten fordi de opplever stor avmakt i møte med systemets representanter, eller fordi de synes det er krevende å vurdere gode strategier innenfor en ny kontekst. «Queens» er tydelige i kommunikasjonen, også dersom de er uenige i bakkebyråkratens vurderinger. «Carers» kjennetegnes av at de viser en uttalt motvilje mot å overstyre deltakerens ønsker - også i situasjoner der de er uenige i deltakerens vurdering - og utsetter beslutninger når de møter deltakere som ikke gir uttrykk for klare preferanser. «Clerks» tenderer derimot til å overstyre deltakerens ønsker dersom de er uenig med han/henne, og til å ta beslutninger på vegne av de som ikke selv gir uttrykk for hva de ønsker.

Bakkebyråkratenes strategier kan være uttrykk for ulike oppfatninger av hva som er i deltakerens interesse. Der «Carers» ser medvirkning som kompetansehevende og dermed som en viktig strategi for å oppnå målene om yrkesdeltakelse og samfunnsdeltakelse på sikt, oppfatter «Clerks» medvirkningen mer som en kilde til informasjon om deltakeren som kan bidra til å gjøre integreringsarbeidet mer effektivt. Både «Clerks» og «Carers» gir imidlertid uttrykk for ambivalens i møte med kvinnelige deltakere som har store omsorgsoppgaver, kjønnstradisjonelle holdninger og som trenger mye opplæring før lønnet arbeid er realistisk. Et intensivt program kan være effektivt, men bare dersom kvaliteten er god. Og kvaliteten er ikke alltid på plass. Enkelte, primært «Carers», tilbyr da et mindre intensivt program, der kvinnenes $ø$ nsker tillegges større vekt, og der innholdet i opplæringen kan bli noe annet enn det bakkebyråkraten vurderer som mest effektivt for rask overgang til lønnet arbeid. 


\title{
5.4 Adapting to the dual earner model? Attitudes to mothers' employment among immigrants and immigrant descendants in Norway.
}

\author{
Hanne C. Kavli, Journal of Ethnic and Migration Studies 2015, Vol 41(5):835-856.
}

I den fjerde artikkelen spør jeg hvilke mønstre som finnes i holdninger til mødres yrkesdeltakelse blant innvandrere og etterkommere i Norge, og hvilke dynamikker som kan bidra til å forme disse mønstrene. Jeg undersøker betydningen av landbakgrunn, kjønn, botid i Norge, norskferdigheter og økonomisk integrering. Analysen bygger på en surveyunders $ø$ kelse blant 1821 personer mellom 20 og 55 år, med bakgrunn fra Iran, Irak, Pakistan og Vietnam samt pakistanske etterkommere og personer uten innvandringsbakgrunn.

Holdningene til mødres yrkesdeltakelse varierer mellom innvandrere fra ulike land også etter at det er tatt hensyn til sosiodemografiske kjennetegn og religiøsitet. Innvandrere fra Pakistan og Irak er mindre positive til mødres yrkesdeltakelse enn innvandrere fra Vietnam og Iran, som igjen skiller seg lite fra holdningsprofilen blant informanter uten innvandringsbakgrunn. Det antas ofte at kvinner vil ha mer å tjene på kjønnslikestilling enn menn, og at de dermed raskere vil ta til seg kjønnslikestilte holdninger. Jeg fant ingen slike kjønnsforskjeller. Jeg finner heller ikke noe som tyder på at innvandrere med lang botid i Norge er mer positive til mødres yrkesdeltakelse, enn innvandrere med kortere botid. Men mine tverrsnittsdata tillater ikke skarpe konklusjoner om eventuelle virkninger av botid - eller mangel på sådanne. Selv om betydningen av innvandreres botid er usikker, finner jeg likevel klare tegn til endring mellom generasjoner. Blant pakistanske etterkommere er holdningene til mødres yrkesdeltakelse vesentlig mer positive enn blant pakistanske innvandrere, om enn mindre positive enn blant personer uten innvandringsbakgrunn.

Dataene viser også at gode norskferdigheter og stabil økonomi er knyttet til en høyere tilslutning til mødres yrkesdeltakelse. For voksne innvandrere ser holdningene til mødres yrkesdeltakelse altså ut til å være relatert til hvordan det er gått med deg etter at du kom til Norge. Funnet reiser både spørsmål om klasseforskjeller og om seleksjonsmekanismer. Det kan være et uttrykk for at det skjer en sterkere, eller raskere, kulturell tilpasning blant innvandrere som har forutsetninger for å lykkes økonomisk i Norge, enn blant de som har en lengre vei fram mot økonomisk integrering. Dette kan også forsterkes av at innvandrere som er i arbeid og som snakker godt norsk, eksponeres for den skandinaviske varianten av kjønnslikestilling i større grad enn de som er uten arbeid, og som i mindre grad kan kommunisere på norsk og dermed oftere er i situasjoner der påvirkning kan skje. Men det kan også handle om at denne gruppen av migranter allerede før migrasjonen var mer positive til mødres yrkesdeltakelse, enn andre med samme landbakgrunn. I så fall er det ikke snakk om kulturell tilpasning, men seleksjon i migrasjonsprosessen. 


\section{Diskusjon og konklusjon}

Bidragene i avhandlingen handler i bred forstand om hvordan vi kan forstå det mønsteret av familiepraksis og kvinners yrkesdeltakelse som avtegner seg blant innvandrere i Norge. Innvandrere møter en samfunnsmodell som består av en særegen kobling mellom arbeidsliv, familieliv og velferdsstat. De møtes også av en normativ forventning om at kvinner skal delta i arbeidslivet og menn i omsorgsarbeid - og av en velferdsstat med ambisjoner om sosial mobilitet, men som samtidig opererer i en kontekst av økende økonomisk ulikhet. Hvilken betydning har dette for hvordan innvandrere løser sine familieliv? Jeg har vært særlig opptatt av å studere forholdet mellom innvandreres økonomiske og kulturelle tilpasninger, og samspillet mellom disse tilpasningene og den norske konteksten. Her vil jeg gi en sammenfattende analyse av avhandlingens hovedfunn, diskutere de viktigste teoretiske og politiske implikasjonene av disse funnene, og i forlengelsen av dette foreslå noen tema for videre forskning.

\subsection{Institusjonelle mulighetsrom i velferdsstat og arbeidsliv}

Et viktig mål for avhandlingsarbeidet har vært å undersøke hvordan innrettingen av velferdsstat og arbeidsliv kan skape ulike institusjonelle mulighetsrom og påvirke innvandreres familiepraksis. Både i neo-assimileringsteori og i segmentert assimileringsteori tillegges bostedslandets institusjoner betydelig vekt. Familiepraksiser, og innenfor dette kvinners yrkesdeltakelse og økonomiske integrering, har likevel fått begrenset oppmerksomhet i denne litteraturen. For å bøte på dette, har jeg trukket inn perspektiver fra studier av arbeidsliv, velferdsstat og kvinners yrkesdeltakelse. På tross av at denne litteraturen i hovedsak har hatt sitt empiriske utgangspunkt i analyser av personer uten innvandringsbakgrunn, gir den viktige innsikter om hvordan samfunnets organisering påvirker ulike typer av familier.

Institusjoner kan, sammen med andre forhold, bidra til å forme mulighetsrom for praksis. I vid forstand kan slike mulighetsrom tenkes å påvirke både hva individer oppfatter som praktisk gjennomførbart og normativt ønskelig. Bostedslandets institusjoner er av stor betydning for innvandreres $ø$ konomiske og kulturelle tilpasninger. Samtidig vil innvandrere ha ulike forutsetninger for å dra nytte av mulighetene - og overkomme barrierene - som bostedslandets ulike institusjoner representerer (Alba \& Foner, 2014). En implikasjon av dette er at betingelsene for økonomisk og kulturell integrering i Norge vil variere mellom ulike grupper av innvandrere, noe jeg også illustrerer i avhandlingen.

Norsk familiepolitikk har et «hovedspor», som er blitt stadig mer framtredende. Dette sporet omfatter ordninger som styrker toforsørgerfamilien og legger til rette for at foreldre kan dele 
omsorgsarbeidet (Ellingsæter, 2016). Sysselsatte innvandrede kvinner følger dette hovedsporet i norsk familiepolitikk og får utbytte av de mulighetene det gir. Dette illustrerer samspillet mellom de ferdighetene og den kompetansen innvandrere har med seg til Norge, eller tilegner seg her, og de mulighetene dette utløser innenfor den norske konteksten. Blant landgruppene i mitt surveymateriale (og hvis vi tillater oss å bruke et enkelt mål for sysselsetting som utgangspunkt) kan dette illustreres ved å sammenlikne innvandrede kvinner fra Iran og Somalia. Blant iranske kvinner i Norge er over halvparten i lønnet arbeid, mot 18 prosent av kvinner i opprinnelseslandet. En høy andel har høyere utdanning, og fertiliteten er lav både i Iran og i Norge. Det høye utdanningsnivået gir flere muligheter i norsk arbeidsliv, lavere fertilitet gir færre avbrudd i kvalifisering og yrkesdeltakelse og de økonomiske insentivene i å orientere seg mot lønnet arbeid vil framstå som relativt tydelige. På det motsatte ytterpunktet finner vi kvinner fra Somalia, der kvinners yrkesdeltakelse er 20 prosent, og bare marginalt høyere i Norge: 29 prosent. Utdanningsnivået blant somaliske kvinner i Norge er lavt (76 prosent mangler videregående utdanning), og fertiliteten er høy, om enn vesentlig lavere enn i opprinnelseslandet. Somaliere møter dermed en annen del av norsk velferds- og familiepolitikk, der ambisjonen er å ivareta behov i familier der mor og/eller far har en svak tilknytning til arbeidslivet. Det er selvsagt store variasjoner ikke bare mellom, men også innenfor hver enkelt landgruppe. De to eksemplene illustrerer likevel hvordan ulik humankapital og ulik familiepraksis bidrar til å styre kvinner enten inn i hovedsporet i norsk familiepolitikk, eller inn på sidesporet.

I artikkel 1 viser jeg at en betydelig andel innvandrere har en mer kjønnslikestilt praksis enn det holdningene deres skulle tilsi. Ifølge neo-assimileringsteorien kan vi forstå dette som et uttrykk for en rasjonell tilpasning til ønsket om å tjene nok til å leve et godt liv. Dissonansen kan dermed være et uttrykk for at den norske konteksten skyver familier med kjønnstradisjonelle holdninger i retning av en mer kjønnslikestilt praksis enn de ellers ville hatt. Dette funnet, gitt den norske konteksten, er sammenfallende med forskning fra andre typer av velferdsregimer. Gowayed (2019) fant for eksempel at lav tilgang til sosiale ytelser og begrenset tilgang til godt lønnede jobber for syriske, nyankomne menn i USA, gjorde det nødvendig at også syriske kvinner og mødre søkte lønnet arbeid. Samspillet mellom økonomiske behov, velferdsstatlige ordninger og strukturer i arbeidslivet løftes fram i flere studier som en faktor som påvirker hvilken innflytelse kjønnstradisjonelle holdninger og verdier kan få for kvinners orientering mot lønnet arbeid (Geist, 2005; Holdsworth \& Dale, 1998; Pinto \& Coltrane, 2009).

Samtidig er det også en betydelig andel innvandrere i mitt surveymateriale med kjønnstradisjonelle holdninger og praksiser som sammenfaller. Ved første øyekast framstår denne gruppen som mer robust i møtet med den norske konteksten enn dem med dissonans mellom holdninger og praksis. En alternativ beskrivelse er at de treffer - og tilpasser seg - andre sider ved de institusjonelle strukturene enn de som, enten i tråd med eller på tross av holdningene sine, lever mer kjønnslikestilt. Hovedsporet i norsk familie- og likestillingspolitikk er tett forbundet med kvinners yrkesdeltakelse. Innvandrede kvinner som av ulike årsaker ikke har lønnet arbeid, og familier som har behov for offentlig inntektssikring, møter andre ordninger, som produserer andre typer av mulighetsrom. Spesielt dersom avstanden mellom 
mulig inntjening i arbeidslivet og størrelsen på offentlige overføringer er liten, reduseres arbeidsinsentivene. Velferdsstatens økonomiske ansvar kan dermed bidra til å vedlikeholde kjønnstradisjonelle holdninger og praksiser i deler av den innvandrede befolkningen. Heri ligger også den viktigste kontroversen rundt kontantstøtten, som av hensyn til innvandrede kvinners deltakelse i kvalifisering er blitt regulert gjennom et botidskrav. Betydningen av å regulere arbeidsinsentivene ved å redusere overføringer, bør likevel ikke overdrives. For at økonomiske insentiver skal være effektive, må de som utsettes for dem har en reell mulighet til å endre atferd - i denne sammenhengen å skaffe seg et lønnet arbeid det er mulig å leve av.

Innvandrere som gruppe har en mer utsatt posisjon i bostedslandenes arbeidsliv enn majoritetsbefolkningen, både når det gjelder ansettelsesforhold, arbeidsbetingelser og lønnsbetingelser (Kalleberg, 2011; Muñoz-Comet, 2016; Vrålstad \& Wiggen, 2017). Innvandrede kvinner kan være særlig utsatt, sammenliknet både med innvandrede menn og med kvinner uten innvandringsbakgrunn (Flippen, 2014; Rubin et al., 2008). Også i mitt bidrag i artikkel 2 blir det tydelig at samspillet mellom individuelle egenskaper og arbeidslivets organisering bør få større plass i forståelsen av innvandrede kvinners økonomiske integrering. Innvandrede kvinner er overrepresentert i typiske deltidsbransjer. Fordi «deltid avler deltid» (Nicolaisen \& Olberg, 2013:39), kan dette gjøre det vanskelig å komme seg videre til en heltidsstilling. At innvandrede kvinner har større sannsynlighet for å øke arbeidstiden sin enn kvinner uten innvandringsbakgrunn, tilsier at en høyere andel arbeider deltid ufrivillig. På den andre siden har innvandrede kvinner, spesielt fra Somalia og Irak, også en høyere risiko for å gå ut av arbeidslivet. Korte deltidsbrøker øker risikoen, men mønsteret er tydelig også blant kvinner som står i en heltidsjobb. I en senere studie støttes dette funnet av tall som viser at bevegelsen ut av arbeidslivet er mest markant blant innvandrere fra Afrika og Asia, der mange har bakgrunn som flyktninger eller som familiegjenforente med flyktninger (Kavli \& Nielsen, 2019).

Blant kvinner fra flere av de store innvandrergruppene i Norge er det en betydelig andel som har lav formell utdanning. Dette gjør det vanskelig å få innpass i arbeidslivet, men er også en utfordring for videre opplæring og kvalifisering i Norge. Blant deltakere med lite skoleerfaring, er progresjonen i norskopplæringen så lav at de også har vansker med å dra nytte av videre opplæringstilbud i regi av NAV (Djuve, Kavli, Sterri, \& Bråten, 2017). Arbeidstakere med lav, formell kompetanse stiller også svakere når det gjelder å ta i bruk rettigheter som er innført for å beskytte de mest utsatte gruppene i arbeidslivet (Nicolaisen et al., 2019). Arbeidsmiljølovens regler for å redusere ufrivillig deltid er et godt eksempel på en regulering som er mindre effektiv i møte med arbeidstakere som har lav formell kompetanse. Dette rammer innvandrede arbeidstakere spesielt, både fordi de er overrepresentert i de delene av arbeidslivet som har relativt lave krav til formell kompetanse (Vrålstad \& Wiggen, 2017), og fordi kravene til skriftlige norskferdigheter for å få jobbe for eksempel i helsevesenet eller i barnehagene, to viktige veier inn i arbeidsmarkedet for innvandrede kvinner, kan være krevende å oppfylle for voksne med lite skoleerfaring (Djuve et al., 2017; Nicolaisen et al., 2019). Også innenfor arbeidslivets domene ser vi dermed at det institusjonelle rammeverket - og det individuelle mulighetsrommet det representerer - varierer for ulike deler av befolkningen. 
Mine analyser illustrerer at det er viktig å se velferdsstatens og arbeidslivets virkemåte overfor innvandrere i sammenheng for å forstå det mønsteret av familiepraksis og kvinners yrkesdeltakelse som avtegner seg. Familiepolitikken skaper både muligheter og insentiver for lønnet arbeid for noen grupper av kvinner, men ikke for alle. Arbeidslivet som møter innvandrede kvinner med lav formell kompetanse, har egenskaper som kan gjøre det krevende både å få innpass og å stå i arbeid over tid. Og selv om integreringspolitikken signaliserer en stadig sterkere forventning om at innvandrede kvinner - også mødre - skal orientere seg mot lønnet arbeid, er kvaliteten på opplæringsarbeidet ikke alltid godt nok til å åpne arbeidslivets porter. Dette siste poenget berører også de dilemmaene som kan oppstå i velferdsstatens førstelinje, når nasjonale intensjoner skal balanseres mot lokale realiteter og individuelle vurderinger.

\subsection{Institusjonelle møter - mellom nasjonale intensjoner, lokale realiteter og individuelle vurderinger}

I den tredje artikkelen er temaet fortsatt hvordan velferdsstatens og arbeidslivets strukturer kan påvirke integreringsprosesser, men nå belyst gjennom møter mellom innvandrere og bakkebyråkrater i velferdsstatens førstelinje. I introduksjonsordningen møter innvandrere et omfattende opplæringsprogram. Ambisjonen er å formidle landets normer og forventninger, tilføre deltakerne det de måtte mangle av kompetanse for å få raskt innpass i norsk arbeidsliv, men også å involvere deltakerne i å utforme en individuell opplæringsplan. Medvirkning åpner for anerkjennelse av deltakernes holdninger og verdier, og for hvordan de ser for seg livet i Norge. I lov og forskrift betones likevel økonomisk integrering sterkere enn deltakers rett til medvirkning (Kavli et al., 2007). Loven kan i så måte tolkes som et uttrykk for en generell tendens i retning av assimilering i europeisk integreringspolitikk (Brubaker, 2001; Joppke, 2007). Assimilering skal i denne sammenheng ikke forstås som at innvandrere skal tilpasse seg alle sider ved vertslandets kultur. Argumentet er snarere at det politiske tyngdepunktet har beveget seg noe vekk fra multikulturalismens vekt på kulturell anerkjennelse, over mot økonomisk integrering kombinert med en mer uttalt bekymring for konsekvensene av verdimessig fragmentering av samfunnet (Hagelund \& Kavli, 2009:260).

Å vurdere hvor langt anerkjennelse av deltakernes ønsker skal gå, er et skjønnsspørsmål som ofte overlates til bakkebyråkratene. Vi viser at det foregår et fortolkningsarbeid i velferdsstatens førstelinje som tidvis dreier politikkens implementering i en annen retning enn det lovgiverne har lagt til grunn. Analysen støtter langt på vei Lipskys tese om at bakkebyråkrater ikke agerer som rene iverksettere av politikk, men også er med på å utforme politikkens innhold. Noen av byråkratene i undersøkelsen iverksetter et arbeidsrettet program, enten i samarbeid eller i konflikt med deltakeren. Andre velger en strategi som i Brehm og Gates' (1999) terminologi ville omtales som sabotasje - de unnlater å iverksette vedtatt politikk. Dette begrunnes på ulike måter: Noen vurderer opplæringstilbudet som så dårlig at de gir etter for deltakernes ønsker, selv om de ikke er i tråd med programmets retningslinjer. Andre legger større vekt på at 
deltakerne, spesielt kvinner med lav utdanning og store omsorgsoppgaver, har begrenset kapasitet til å følge et omfattende opplæringsprogram. Og noen mener at å gi deltakerne reell innflytelse, selv om det betyr et program i konflikt med lovens retningslinjer, på lang sikt gir best resultat. Utfallet kan, i alle tre tilfeller, bli et mindre intensivt og mindre arbeidsrettet program enn det loven legger opp til.

I velferdsstatens førstelinje treffer dermed ikke innvandrere nødvendigvis en entydig forventning om rask overgang til lønnet arbeid. Noen, spesielt kvinner med lite utdanning og mye omsorgsansvar, møter byråkrater som fortolker regelverket - eller tøyer det - slik at det skal bli lettere å balansere familieliv med å delta i introduksjonsprogrammet. Ikke bare i familiepolitikken, men også i integreringspolitikken, er det dermed et samspill mellom hvilke forutsetninger innvandrere har og hva slags tilbud de får. Et av avhandlingens bidrag er etter mitt syn også illustrasjonen av den rollen egenskaper ved deltakerne i programmet, og deres holdninger og preferanser, kan ha i å prege politikkens implementering. I litteraturen om bakkebyråkrater, implementering og skjønnsutøvelse har byråkratenes ulike handlingsmotiver fått mye plass. Deltakernes beveggrunner reduseres oftere til mikroøkonomiske avveininger av hva som lønner seg økonomisk eller ikke, mens de mer relasjonelle aspektene ved politikkens implementering er mindre studert (Wright, 2012). Spørsmålet om hva som legger rammer for innvandreres mulighetsrom bør derfor favne bredere enn analyser av de formelle, institusjonelle strukturene - og avhandlingen gir i så måte et bidrag til forskningen på feltet.

\subsection{Institusjonell eksponering}

I artikkel 4 retter jeg søkelyset mot innvandreres og etterkommeres holdninger til mødres yrkesdeltakelse. Et vesentlig spørsmål er om det spiller noen rolle for holdningene hvor lenge du har vært eksponert for den norske institusjonelle konteksten, eller om det handler mer om hvem du er og hvordan det har gått med deg i Norge. Jeg finner at holdningene til mødres yrkesdeltakelse er relatert både til økonomi og til norskferdigheter. Blant innvandrere med svak økonomi og dårlige norskferdigheter er oppslutningen om mødres yrkesdeltakelse lavere, enn blant innvandrere med gode norskferdigheter og sterkere økonomi. Dette kan både handle om at det skjer en raskere kulturell tilpasning blant de som i utgangspunktet hadde gode forutsetninger for å lære seg norsk og integreres økonomisk, og om at de som har migrert til Norge allerede i utgangspunktet var mer positive til mødres yrkesdeltakelse enn de som ikke migrerte, eller som migrerte til andre land. Det kan også handle om at deltakelse i arbeidslivet og mulighet til å kommunisere på norsk i seg selv gir større eksponering for den norske konteksten. Man er rett og slett oftere i en situasjon der man kan bli påvirket. Forskjellene i oppslutning rundt mødres yrkesdeltakelse kan også tenkes å være et uttrykk for at norsk velferds- og familiepolitikk har etablert ulike typer av insentivstrukturer for familier med ulike forutsetninger for å lykkes i norsk arbeidsliv. 
Innvandreres holdninger til mødres yrkesdeltakelse ser i liten grad ut til å variere med botid i Norge. Her vil jeg presisere at tverrsnittsdata ikke gir rom for skarpe konklusjoner om betydningen av botid. Samtidig tyder et økende antall studier på at botid - og eksponering for bostedslandets institusjoner - kan påvirke innvandreres holdninger. Innvandrere fra kjønnstradisjonelle regimer har ganske visst mer kjønnstradisjonelle holdninger enn befolkningen i det landet de har migrert til, også etter at individuelle karakteristikker er tatt hensyn til (Norris \& Inglehart, 2012; Roder \& Mühlau, 2014). Opprinnelseskonteksten ser likevel ut til å miste noe av sin forklaringskraft over tid, og både innvandrere og etterkommere nærmer seg holdningsprofilen til befolkningen i det landet de bor. Flere finner også at det for innvandrere har større betydning «hvor du bor» enn «hvem du er»: bostedslandet har en sterkere sammenheng med holdningene til kjønnslikestilling enn individuelle egenskaper som kjønn, alder, utdanning og inntekt (Breidahl \& Larsen, 2016; Norris \& Inglehart, 2012; Roder \& Mühlau, 2014; Röder, 2014). Det er med utgangspunkt i dette at Breidahl og Larsen (2016) argumenterer for at innvandreres holdninger til kvinners lønnsarbeid er nært knyttet til den institusjonelle og kulturelle konteksten i bostedslandet. Argumentet styrkes av at holdningene til mødres yrkesdeltakelse blant innvandrere fra samme (opprinnelses)land, varierer etter hvor de er bosatt. Også når det gjelder oppfatning av offentlige myndigheters ansvar for å tilby velferdstjenester (Bredgaard \& Larsen, 2008; Reeskens \& Van Oorschot, 2015) og nivået på generalisert og institusjonell tillit (Dinesen \& Hooghe, 2010; Nannestad \& Svendsen, 2005), er det klare tegn til at innvandrere med lang botid ligger nærmere de holdningene som dominerer i bostedslandet, enn innvandrere med kortere botid.

Betydningen av botid, eller kanskje snarere av å vokse opp innenfor den norske, institusjonelle konteksten, framstår klarere blant barn av innvandrere. Oppslutningen om mødres yrkesdeltakelse er langt større blant pakistanske etterkommere enn blant pakistanere som selv har innvandret. Dette føyer seg inn i et mønster der etterkommernes familiepraksiser og holdninger nærmer seg de som dominerer i majoritetsbefolkningen. Forskjellen, sammenliknet med de som selv har innvandret, kommer til uttrykk gjennom deltakelse i høyere utdanning, alder ved ekteskapsinngåelse, større autonomi i ekteskapsbeslutningene, lavere fertilitet og høyere yrkesdeltakelse også i småbarnsfasen (Hermansen, 2012; Kavli \& Nadim, 2009). Det er rimelig å anta at det norske utdanningssystemet bidrar i denne prosessen. Dels fordi skolen representerer en viktig sosialiseringsarena, med omfattende «opplæring» i kjønnslikestilling, også for barn av foreldre med kjønnstradisjonelle holdninger og praksiser. Og dels fordi det er en godt dokumentert sammenheng mellom høy utdanning og oppslutning om kjønnslikestilling (Inglehart \& Norris, 2003). Muligheten til å ta utdanning også for barn som vokser opp i familier med dårlig økonomi, er større innenfor rammen av et offentlig finansiert skolesystem i en egalitær velferdsstat. Dette kan være fordelaktig for barn av innvandrere, som er mer utsatt for å vokse opp i lavinntektsfamilier (Epland, 2018).

Samtidig finner jeg at oppslutningen om mødres yrkesdeltakelse er lavere blant pakistanske etterkommere enn blant personer uten innvandringsbakgrunn. Dette er i tråd med andre studier, som viser at tilpasning og endring blant barn av innvandrere er kombinert med kontinuitet og videreføring. Flere har påpekt at de forskjellene vi finner mellom innvandrere og 
etterkommere, ikke nødvendigvis dreier seg om en bevegelse langs et kontinuum fra kjønnstradisjonelle til kjønnslikestilte holdninger og praksiser. Det kan også signalisere at det skapes noe nytt, ved at etterkommere fortolker, utfordrer og forhandler fram nye (familie)praksiser i skjæringsfeltet mellom det de vokser opp med hjemme, og det de møter ute (Kindt, 2019; Nadim, 2014, 2016; Prieur, 2002:72).

\subsection{Videre forskning}

Norge har vært vitne til betydelige endringer i kjønnsrollemønsteret i løpet av de siste tre generasjonene (Lappegård \& Noack, 2008; Nielsen \& Rudberg, 2000). Slike endringsprosesser foregår også i den innvandrede befolkningen. Avhandlingen illustrerer at familiepraksis og likestilling blant innvandrere i Norge ikke lar seg beskrive eller forstå ved å tegne opp en linje med ett enkelt utviklingsløp. Den innvandrede befolkningen i Norge vokser, og blir samtidig stadig mer kompleks. Denne kompleksiteten har betydning for hvordan vi kan studere innvandreres tilpasninger til, og integrering i, norsk samfunns- og arbeidsliv. For noen grupper, og på noen områder, er avstanden til holdninger og praksiser i majoritetsbefolkningen det man først legger merke til. I andre grupper og på andre områder er det likhetene som er mest slående. Derfor blir det ofte lite treffende å analysere innvandrere under ett, og vi står i fare for å miste sentrale forskjeller av syne både mellom, og innenfor landgrupper. Videre har sammensetningen av etterkommerne rukket å endre seg betydelig. De har økt i antall, flere har egne barn og for de som i dag starter voksenlivet, har noen gått foran i løypa. De etterkommerne som var først i sine kull - og som jeg har med i min studie - kan derfor skille seg fra de som kom etter. Dette tilsier at videre studier av etterkommere kan finne nye mønster knyttet til familiepraksis og kvinners yrkesdeltakelse enn det som avtegnet seg blant de pakistanske etterkommerne vi intervjuet i 2008.

Også det samfunnet som møter innvandrere i Norge, har endret seg i løpet av den tiden innvandrerne i mitt utvalg har bodd i Norge og i løpet av den tiden som er gått siden spørreundersøkelsen. For 40 år siden uttrykte myndighetene bekymring for «assimileringsrisikoen» ved bruk av barnehage for barn av innvandrere (Stortingsmelding 74, 1979/80: s. 90). I dag løftes barnehage fram som et sentralt integreringspolitisk virkemiddel. Innvandrere som er kommet til Norge de siste 10 årene, har møtt subsidierte og tilgjengelige barnehager for alle, og et omfattende, om enn ikke alltid like arbeidsrettet, introduksjonsprogram. De som innvandret for 20 eller 30 år siden, møtte verken et system som var like godt tilrettelagt for at kvinner kunne kombinere lønnet arbeid og omsorgsarbeid, eller en integreringspolitikk som målrettet arbeidslinja også mot kvinner. Både de institusjonelle strukturene og storsamfunnets forventninger om tilpasning har altså endret seg over tid. Videre studier av hvordan bostedskontekst påvirker innvandreres familiepraksis, kan møte noen av de utfordringene dette skaper, for eksempel ved å rette analysen mot innvandrere med kort botid, eller ved å følge innvandreres økonomiske og kulturelle tilpasningsprosesser over tid, med gjentatte målinger av holdninger og praksis. 
Høyere yrkesdeltakelse blant innvandrede kvinner representerer ikke nødvendigvis bedre økonomisk integrering for de som blir værende i de mest ustabile og lavest lønnede delene av arbeidslivet. Det går en linje fra kvaliteten på den opplæringen kvinner - og menn - med lav formell kompetanse får tilbud om etter ankomst til Norge, og til den posisjonen de har mulighet til å få i norsk arbeidsliv på sikt. For innvandrede kvinner har likevel mye oppmerksomhet blitt knyttet til betydningen av holdninger og verdier, og mindre til betydningen av at kvinner har ulike forutsetninger og møter ulike muligheter. Den kjønnsdualistiske tenkningen, der kvinners forhold til lønnsarbeid primært forklares gjennom familieforhold, og ikke med muligheter og betingelser i arbeidslivet (Ellingsæter, 2017), er fortsatt til stede i både forskning og offentlig debatt rundt innvandrede kvinners yrkesdeltakelse. Etter mitt syn er det derfor en viktig oppgave å bringe fram mer kunnskap om innvandrede kvinner som arbeidstakere, ikke bare som mødre og kulturbærere.

Familiepraksiser og kjønnsroller er ikke statiske. Selv om mye varer ved, påvirkes vi også av ideer og praksiser i et samfunn som er i stadig endring. Heraklit satte ord på forandringens evige strøm på denne måten: «Du kan ikke stige ned i den samme elven to ganger. Akkurat som elven der jeg setter min fot ikke er den samme, og likevel er, slik er jeg det som jeg ikke er» (som referert i Hernes 2006:114). Endring er normaltilstanden, både for de som flytter seg og sine over hav og kontinenter, og for de som blir værende på plassen der foreldrene og besteforeldrene vokste opp. Vi endrer - og endres - av hverandre. Integrering blir i dette perspektivet en toveis prosess, og det norske samfunnet ikke noe som er, men noe som hele tiden blir (Hernes, 2006:114). 


\section{Referanseliste}

Akkerman, T., \& Hagelund, A. (2007). 'Women and children first!' Anti-immigration parties and gender in Norway and the Netherlands. Patterns of Prejudice, 41(2), 197-214.

Alba, R., \& Foner, N. (2014). Comparing immigrant integration in North America and Western Europe: How much do the grand narratives tell us? International Migration Review, 48, S263-S291.

Alba, R., \& Nee, V. (2005). Remaking the American mainstream: Assimilation and contemporary immigration. Cambridge, Massachusetts, and London, England: Harvard University Press.

Barth, E., Bratsberg, B., \& Raaum, O. (2004). Identifying earnings assimilation of immigrants under changing macroeconomic conditions. Scandinavian Journal of Economics, 106(1), 1-22.

Baxter, J., Buchler, S., Perales, F., \& Western, M. (2015). A Life-Changing Event: First Births and Men's and Women's Attitudes to Mothering and Gender Divisions of Labor. Social Forces, 93(3), 989-1014.

Becker, G. S. (1964/1993). Human Capital. A Theoretical and Empirical Analysis, with Special Reference to Education. Chicago and London: The University of Chicago Press.

Bjørnholt, M., \& Stefansen, K. (2019). Same but different: Polish and Norwegian parents' work-family adaptations in Norway. Journal of European Social Policy, O(0), 0958928718758824. doi:10.1177/0958928718758824

Borjas, G. J. (1999). Immigration and welfare magnets. Journal of Labor Economics, 17(4), 607-637.

Bratsberg, B., Røed, K., \& Raaum, O. (2011). Yrkesdeltaking på lang sikt blant ulike innvandrergrupper $i$ Norge. Oslo: Frisch-rapport 1, 2011.

Bratsberg, B., Raaum, O., \& Røed, K. (2018). Job Loss and Immigrant Labour Market Performance. Economica, 85(337), 124-151.

Bredgaard, T., \& Larsen, F. (2008). Quasi-markets in employment policy: do they deliver on promises? Social Policy and Society, 7(3), 341-352.

Brehm, J. O., \& Gates, S. (1999). Working, shirking, and sabotage: Bureaucratic response to a democratic public. University of Michigan Press.

Breidahl, K. N., \& Larsen, C. A. (2016). The myth of unadaptable gender roles: Attitudes towards women's paid work among immigrants across 30 European countries. Journal of European Social Policy, 26(5), 387-401.

Brochmann, G. (2017, 23 oktober). Integrering. Store norske leksikon.(Hentet 26. september 2019 fra https://snl.no/integrering).

Brochmann, G., \& Grødem, A. S. (2017). Den norske modellens møte med innvandring-et regime i endring. I M. A. Stamsø (red.), Velferdsstaten i endring: Om norsk helse-og sosialpolitikk (3. utg). Oslo: Gyldendal Akademisk.

Brochmann, G., Borchgrevink, T., \& Rogstad, J. (2002). Sand i maskineriet: Makt og demokrati i det flerkulturelle Norge. Oslo: Gyldendal Akademisk.

Brodkin, E. Z. (2011). Policy Work: Street-Level Organizations Under New Managerialism. Journal of Public Administration Research and Theory, 21, I253-I277.

Brubaker, R. (2001). The return of assimilation? Changing perspectives on immigration and its sequels in France, Germany, and the United States. Ethnic and Racial Studies, 24(4), 531-548.

Bråten, B., Drange, N., Haakestad, H., \& Telle, K. (2014). Gratis kjernetid i barnehager. Fafo-rapport 2014:44, Oslo: Fafo.

Byberg, I. H. (2002). Innvandrerkvinner i Norge. Demografi, utdanning, arbeid og inntekt. Oslo/Kongsvinger: Statistisk sentralbyrå.

Careja, R. (2019). Immigrants' labor market outcomes: Contributions from multilevel studies. KZfSS Kölner Zeitschrift für Soziologie und Sozialpsychologie, 1-34.

Crompton, R., \& Harris, F. (1998a). Explaining women's employment patterns:'orientations to work'revisited. British Journal of Sociology, 118-136.

Crompton, R., \& Harris, F. (1998b). Explaining Women's Employment Patterns: 'Orientations to Work' Revisited. The British journal of sociology, 49(1), 118-136.

Crompton, R., Brockmann, M., \& Lyonette, C. (2005). Attitudes, women's employment and the domestic division of labour: a cross-national analysis in two waves. Work, employment and society, 19(2), 213-233. 
Crul, M., \& Schneider, J. (2010). Comparative integration context theory: participation and belonging in new diverse European cities. Ethnic and Racial Studies, 33(7), 1249-1268.

Crul, M., Schneider, J., \& Lelie, F. (2012). The European second generation compared: Does the integration context matter? IMISCO research: Amsterdam University Press.

Deding, M., Fridberg, T., \& Jakobsen, V. (2008). Non-response in a survey among immigrants in Denmark. Survey Research Methods, 2(3), 107-121.

Dinesen, P. T., \& Hooghe, M. (2010). When in Rome, do as the Romans do: the acculturation of generalized trust among immigrants in Western Europe. International Migration Review, 44(3), 697-727.

Diop-Christensen, A. (2015). Is 'making work pay'effective for the 'unemployable'? The impact of benefit sanctions on social assistance recipients in Denmark. Journal of European Social Policy, 25(2), $210-224$

Djuve, A. B. (2011). Introduksjonsordningen for nyankomne innvandrere: Et integreringspolitisk paradigmeskifte. Doktorgradsavhandling v/institutt for statsvitenskap, Universitetet i Oslo.

Djuve, A. B., \& Kavli, H. C. (2007). Integreringspolitikk i endring. I J. E. Dølvik, T. Fløtten, G. Hernes, \& J. M. Hippe (red.), Det store hamskiftet. Oslo: Gyldendal Akademisk.

Djuve, A. B., \& Kavli, H. C. (2019). Refugee integration policy the Norwegian way - why good ideas fail and bad ideas prevail. Transfer: European Review of Labour and Research, 25(1), 25-42.

Djuve, A. B., \& Pettersen, H. C. (1998a). Må de være ute om vinteren? Oppfatninger om barnehager i fem etniske grupper i Oslo. Fafo-rapport 262, Oslo: Fafo.

Djuve, A. B., \& Pettersen, H. C. (1998b). Nasjonale intensjoner - lokal virkelighet. Etterspørsel etter - og bruk av - barnehager blant innvandrerforeldre i Bergen, Trondheim og Oslo. Fafo-notat 1998:05, Oslo: Fafo.

Djuve, A. B., Gulløy, E., Kavli, H. C., \& Berglund, F. (2009). Datafangst når minoritetsbefolkningen er målgruppe. Fafo-rapport 2009:24, Oslo: Fafo.

Djuve, A. B., Kavli, H. C., \& Hagelund, A. (2011). Kvinner i kvalifisering. Introduksjonsprogram for nyankomne flyktninger med liten utdanning og store omsorgsoppgaver. Fafo-rapport 2011:02, Oslo: Fafo.

Djuve, A. B., Kavli, H. C., Sterri, E. B., \& Bråten, B. (2017). Introduksjonsprogram og norskopplæring. Hva virker - for hvem? Fafo-rapport 2017:31, Oslo: Fafo.

Doeringer, P., \& Piore, M. J. (1971). Internal labor markets and manpower analysis. New York, England: E. Sharp Inc, DC Heath and Company.

Drange, N., \& Telle, K. (2015). Promoting integration of immigrants: Effects of free child care on child enrollment and parental employment. Labour Economics, 34, 26-38.

Dzamarija, M. T. (2017). Stadig flere som fødes i Norge har innvandrerbakgrunn. Statistisk sentralbyrå. https://www.ssb.no/befolkning/artikler-og-publikasjoner/stadig-flere-som-fodes-i-norge-harinnvandrerbakgrunn

Dølvik, J. E. (2013). Grunnpilarene i de nordiske modellene. Et tilbakeblikk på arbeidslivs- og velferdsregimenes utvikling. NordMod 2030. Delrapport 1. Fafo-rapport 2013:13, Oslo: Fafo.

Ellingsæter, A. L. (2016). Kampen om familiepolitikken: Farvel til hybridregimet? Tidsskrift for samfunnsforskning, 57(03), 227-256.

Ellingsæter, A. L. (2017). Vår tids moderne tider: det norske arbeidstidsregimet. Oslo: Universitetsforlaget.

Ellingsæter, A. L., \& Jensen, R. S. (2019). Politicising Women's Part-Time Work in Norway: A Longitudinal Study of Ideas. Work, employment and society, 33(3): 444-461.

Ellingsæter, A. L., \& Leira, A. (2006). Politicising parenthood in Scandinavia: Gender relations in welfare states. Bristol, G.B: Policy Press.

Elster, J. (1989). Nuts and bolts for the social sciences. Cambridge University Press.

Emmenegger, P., Häusermann, S., Palier, B., \& Seeleib-Kaiser, M. (2012). How we grow unequal. In P. Emmenegger, S. Häusermann, B. Palier, \& M. Seeleib-Kaiser (Eds.), The age of dualization: The changing face of inequality in deindustrializing societies (pp. 3-26). USA: Oxford University Press.

Epland, J. (2018). Flere barn i husholdninger med vedvarende lav inntekt. Inntekts- og formuestatistikk for husholdninger. Oslo/Kongsvinger: Statistisk sentralbyrå.

Esping-Andersen, G. (1990). The three worlds of welfare capitalism. Princeton University Press: Great Britain.

Esping-Andersen, G. (2009). Incomplete revolution: Adapting welfare states to women's new roles. Polity.

Evans, T. (2010). Professionals, managers and discretion: Critiquing street-level bureaucracy. The British Journal of Social Work, 41(2), 368-386.

Favell, A. (2001). Integration policy and integration research in Europe: a review and critique. Citizenship today: global perspectives and practices, 349, 351-352. 
Feiring, E. (1996). Lek og lær! En evaluering av skolefritidsordningen i Oslo kommune. Fafo-notat 1996:5. Oslo: Fafo.

Feskens, R., Hox, J., Lensvelt-Mulders, G., \& Schmeets, J. (2007). Nonresponse Among Ethnic Minorities: A Multivariate Analysis. Journal of official statistics, 23(3), 387-408.

Festinger, L. (1957). A theory of cognitive dissonance (Vol. 2). California: Stanford University Press.

Festinger, L., \& Carlsmith, J. M. (1959). Cognitive consequences of forced compliance. The journal of abnormal and social psychology, 58(2), 203.

Flippen, C. A. (2014). Intersectionality at work: Determinants of labor supply among immigrant Latinas. Gender \& Society, 28(3), 404-434.

Friberg, J. H., \& Midtbøen, A. H. (2017). Innvandrernes etterkommere: Teoretiske og komparative perspektiver. Norsk sosiologisk tidsskrift, 1(01), 5-14.

Gash, V. (2008a). Bridge or Trap? Temporary Workers' Transitions to Unemployment and to the Standard Employment Contract. European sociological review, 24(5), 651-668.

Gash, V. (2008b). Preference or constraint? Part-time workers' transitions in Denmark, France and the United Kingdom. Work, employment and society, 22(4), 655-674.

Geist, C. (2005). The welfare state and the home: Regime differences in the domestic division of labour. European sociological review, 21(1), 23-41.

Goerres, A., \& Tepe, M. (2012). Doing it for the kids? The determinants of attitudes towards public childcare in unified Germany. Journal of Social Policy, 41(2), 349-372.

Gowayed, H. (2019). Diverging by Gender: Syrian Refugees' Divisions of Labor and Formation of Human Capital in the United States. Gender \& Society, 33(2), 251-272.

Grambo, A.-C., \& Nicolaisen, H. (2015). Engangsstønad ved fødsel. Arbeid og velferd, 3, 135-152.

Grødem, A. S. (2017). Family-oriented policies in Scandinavia and the challenge of immigration. Journal of European Social Policy, 27(1), 77-89.

Hagelund, A., \& Kavli, H. (2009). If work is out of sight. Activation and citizenship for new refugees. Journal of European Social Policy, 19(3), 259-270.

Hagelund, A., \& Kavli, H. C. (2017). Integration. I Handbook of Social Policy Evaluation (s. 383-402). Cheltenham UK, Massachusetts USA: Edward Elgar Publishing.

Hakim, C. (1991). Grateful slaves and self-made women: fact and fantasy in women's work orientations. European sociological review, 7(2), 101-121.

Hakim, C. (2000). Work-lifestyle choices in the 21st century: Preference theory. Oxford University Press, USA.

Hakim, C. (2006). Women, careers, and work-life preferences. British Journal of Guidance \& Counselling, $34(3), 279-294$.

Halrynjo, S., \& Lyng, S. T. (2009). Preferences, constraints or schemas of devotion? Exploring Norwegian mothers' withdrawals from high-commitment careers. British Journal of Sociology, 60(2), 321343.

Hamnes-Carlsen, C. (2017, 29 mars). Trenger en taxisjåfør kunne skrive norske argumenterende tekster på akademisk nivå?, Kronikk. Aftenposten. Lastet ned fra https://www.aftenposten.no/meninger/debatt/i/Aa1Mz/Trenger-en-taxisjafor-a-kunne-skrivenorske_-argumenterende-tekster-pa-pre-akademisk-niva---Cecilie-Hamnes-Carlsen

Hamre, K. (2017). Kontantstøtte blant innvandrere, 2015. Økte forskjeller i kontantstøttebruk. Oslo/Kongsvinger: Statistisk sentralbyrå.

Harding, S. (2016). Whose science? Whose knowledge?: Thinking from women's lives. Cornell University Press.

Havnes, T., \& Mogstad, M. (2011). No child left behind: Subsidized child care and children's long-run outcomes. American Economic Journal: Economic Policy, 3(2), 97-129.

Heath, A., \& Cheung, S. Y. (eds.) (2007). Unequal chances: Ethnic minorities in Western labour markets. Oxford University Press for the British Academy, Oxford.

Heinesen, E., Winter, S., Bøge, I. R., \& Husted, L. (2004). Kommunernes integrationsindsats og integrationssucces. AKF Forlag.

Hellevik, O. (1991). Forskningsmetode i sosiologi og statsvitenskap. Oslo:Universitetsforlaget AS.

Hellevik, O. (2015). Hva betyr respondentbortfallet i intervjuundersøkelser? Tidsskrift for samfunnsforskning, 56(02), 211-229.

Hermansen, A. S. (2012). Occupational attainment among children of immigrants in Norway: bottlenecks into employment - equal access to advantaged positions? European sociological review, 29(3), 517-534.

Hernes, G. (2006). Heraklit i passkontrollen. Integreringskartet, 1, 113-120. Oslo: Integrerings- og mangfoldsdirektoratet. 
Himmelweit, S., \& Sigala, M. (2004). Choice and the relationship between identities and behaviour for mothers with pre-school children: Some implications for policy from a UK study. Journal of Social Policy, 33(3), 455-478.

Holdsworth, C., \& Dale, A. (1998). Why don't minority ethnic women in Britain work part-time? In J. O’Reilly \& C. Fagan (Eds.), Part-Time Prospects. An International Comparison of Part-Time Work in Europa, North-America and the Pacific Rim. London/New York: Routledge.

Holmøy, A., \& Wiggen, K. S. (2017). Levekårsundersøkelsen blant personer med innvandrerbakgrunn 2016. Dokumentasjonsrapport. Notater 2017:20 (8253795416). Oslo/Kongsvinger: Statistisk sentralbyrå.

Hook, J. L. (2010). Gender inequality in the welfare state: Sex segregation in housework, 1965-2003. American Journal of Sociology, 115(5), 1480-1523.

Haavind, H. (1984). Love and power in marriage. I H. Holter (red.), Patriarchy in a welfare society (s. 136168). Oxford University Press.

Inglehart, R., \& Norris, P. (2003). Rising tide: Gender equality and cultural change around the world. Cambridge University Press.

Joppke, C. (2007). Beyond national models: Civic integration policies for immigrants in Western Europe. West European Politics, 30(1), 1-22.

Kalleberg, A. L. (2009). Precarious work, insecure workers: Employment relations in transition. American Sociological Review, 74(1), 1-22.

Kalleberg, A. L. (2011). Good Jobs, Bad Jobs: The Rise of Polarized and Precarious Employment Systems in the United States, 1970s-2000s. New York: Russell Sage Foundation.

Kangas, O., \& Rostgaard, T. (2007). Preferences or institutions? Work-family life opportunities in seven European countries. Journal of European Social Policy, 17(3), 240-256.

Kavli, H. C. (2004). Familiepolitiske dilemma i det flerkulturelle samfunnet. I A. L. Ellingsæter \& A. Leira (red.), Nye familier - ny familiepolitikk? Oslo: Gyldendal Akademisk.

Kavli, H. C. (2012). Verdier på vandring. Arbeidsdeling i innvandrede familier. I A. L. Ellingsæter \& K. Wideberg (red.), Velferdsstatens familier. Nye sosiologiske perspektiver. Oslo: Gyldendal Akademisk.

Kavli, H. C., \& Nadim, M. (2009). Familiepraksis og likestilling i innvandrede familier. Fafo rapport 2009:39, Oslo: Fafo.

Kavli, H. C., \& Nielsen, R. (2019). Stepping in, stepping out or staying put? Part-time work and immigrant integration in Norway. In H. Nicolaisen, H. C. Kavli, \& R. S. Jensen (Eds.), Dualisation of part-time work. The development of labour market insiders and outsiders (pp. 159-186). Great Britain: Policy Press.

Kavli, H. C., Hagelund, A., \& Bråthen, M. (2007). Med rett til å lære og plikt til å delta. En evaluering av introduksjonsordningen for nyankomne flyktninger og innvandrere. Fafo rapport 2007:34, Oslo: Fafo.

Kavli, H. C., Nielsen, R. A., \& Sandbæk, M. L. (2010). Stønadsordningen for enslige forsørgere. Hvordan fungerer den for mottakere med innvandrerbakgrunn? Fafo-rapport 2010:32, Oslo: Fafo.

Kindt, M. T. (2019). Negotiating independence and tradition: plans for career, marriage and family among daughters of immigrants enrolled in higher education in Norway. Journal of Ethnic and Migration Studies, 1-17. DOI: 10.1080/1369183X.2019.1590186

Kitterød, R. H. (2004). Hvem gjør mest hjemme? Hva sier mor og hva sier far? Samfunnsspeilet, 6(2004). Oslo/Kongsvinger: Statistisk sentralbyrå.

Kitterød, R. H., Halrynjo, S., \& Østbakken, K. M. (2017). Pappaperm? Fedre som ikke tar fedrekvote - hvor mange, hvem og hvorfor? Rapport 2017:2. Oslo: Institutt for samfunnsforskning.

Kogan, I. (2006). Labor markets and economic incorporation among recent immigrants in Europe. Social Forces, 85(2), 697-721.

Kogan, I. (2016). Integration Policies and Immigrants' Labor Market Outcomes in Europe. Sociological science, 3, 335-358.

Korpi, W., Ferrarini, T., \& Englund, S. (2013). Women's opportunities under different family policy constellations: Gender, class, and inequality tradeoffs in western countries re-examined. Social Politics: International Studies in Gender, State \& Society, 20(1), 1-40.

Kumlin, S., \& Rothstein, B. (2005). Making and breaking social capital: The impact of welfare-state institutions. Comparative political studies, 38(4), 339-365.

Lappegård, T., \& Noack, T. (2008). Familie og jobb i ulike kvinnegenerasjoner: barn, familie og jobb holdninger og praksis gjennom 30 år. Samfunnsspeilet, 5(6), 20-24.

Leira, A. (2002). Working parents and the welfare state: Family change and policy reform in Scandinavia. Cambridge: Cambridge University Press. 
Levine, D. (1985). The Flight From Ambiguity. Essays on Cultural and Social Theory. Chicago: University of Chicago Press.

Lewis, J. (1992). Gender and the development of welfare regimes. Journal of European Social Policy, 2(3), 159-173.

Lewis, J., \& Nicholls, C. M. (2013). Design issues. In J. Ritchie, J. Lewis, C. M. Nicholls, \& R. Ormston (Eds.), Qualitative Research Practice. A Guide for Social Science Students and Researchers. Second Edition United Kingdom: SAGE.

Lipps, O. \& Ochsner, M. (2019). Additional Languages and Representativeness. Chapter 39 in Johnson, Pennell, Stoop \& Dorer (Eds.), Advances in Comparative Survey Methods. USA: Wiley.

Lipsky, M. (1980). Street level bureaucrats. Dilemmas of the Individual in Public Services. New York: Russel Sage.

Lister, R. (1990). Women, economic dependency and citizenship. Journal of Social Policy, 19(4), 445-467.

Lister, R. (1994). She has other duties': Women, citizenship and social security. Social security and social change: New challenges to the Beveridge model, 31-44.

May, P. J., \& Winter, S. C. (2009). Politicians, Managers, and Street-Level Bureaucrats: Influences on Policy Implementation. Journal of Public Administration Research and Theory, 19(3), 453-476.

Maxwell, R. (2010). Evaluating migrant integration: political attitudes across generations in Europe. International Migration Review, 44(1), 25-52.

McRae, S. (2003). Constraints and choices in mothers' employment careers: a consideration of Hakim's preference theory. The British journal of sociology, 54(3), 317-338.

Messenger, J. C., Lee, S., \& McCann, D. (2007). Working time around the world: Trends in working hours, laws, and policies in a global comparative perspective. International Labour Office, Geneva. London/New York: Routledge.

Mordal, T. L. (1989). Som man spør, får man svar: arbeid med survey-opplegg. Oslo: Tano.

Muñoz-Comet, J. (2016). Potential Work Experience as Protection against Unemployment: Does it bring Equal Benefit to Immigrants and Native Workers? European sociological review, 32(5), 537-551.

Myrberg, G. (2013). Surveying migrants and migrant associations in Stockholm. Surveying ethnic minorities and immigrant populations: Methodological challenges and research strategies, 131-146.

Nadim, M. (2014). Reinterpreting the relation between motherhood and paid work: second-generation immigrant women in Norway. The Sociological Review, 62(3), 494-511.

Nadim, M. (2016). Undermining the male breadwinner ideal? Understandings of women's paid work among second-generation immigrants in Norway. Sociology, 50(1), 109-124.

Nakamura, A., \& Nakamura, M. (1992). The econometrics of female labor supply and children. Econometric Reviews, 11(1), 1-71.

Nannestad, P., \& Svendsen, G. T. (2005). Institutions, culture and trust. Göteborg: The Quality of Government Institute, Göteborg University.

Nee, V., \& Alba, R. (2013). Assimilation as Rational Action in Contexts Defined by Institutions and Boundaries. Chapter 10 in R. Wittek, T. A. B. Snijders \& V. Nee (Eds.). The Handbook of Rational Choice Social Research. Palo Alto: Stanford University Press.

Nicolaisen, H., \& Olberg, D. (2013). Arbeidstid - dilemmaer og utfordringer. Fafo-rapport 2013:17, Oslo: Fafo.

Nicolaisen, H., Kavli, H. C., \& Trygstad, S. (2019). Workplace responses to national regulations: the making of 'good' and 'bad' part-time jobs. In H. Nicolaisen, H. C. Kavli, \& R. S. Jensen (Eds.), The Dualisation of part-time work. The making of labour market insiders and outsiders. Kent: Policy Press.

Nielsen, H. B., \& Rudberg, M. (2000). Gender, Love and Education in Three Generations:The Way Out and Up. European Journal of Women's Studies, 7(4), 423-453.

Norris, P., \& Inglehart, R. F. (2012). Muslim integration into Western cultures: Between origins and destinations. Political Studies, 60(2), 228-251.

Nothdurfter, U., \& Hermans, K. (2018). Meeting (or not) at the street level? A literature review on streetlevel research in public management, social policy and social work. International Journal of Social Welfare, 27(3), 294-304.

NOU (2001:20). Lov om introduksjonsordning for nyankomne innvandrere (introduksjonsloven). Hentet fra https://www.regjeringen.no/no/dokumenter/nou-2001-20/id143913/.

NOU (2017:6). Offentlig støtte til barnefamiliene. Hentet fra https://www.regjeringen.no/contentassets/6ee74831e812490dad20852b7306dc11/no/pdfs/n ou201720170006000dddpdfs.pdf.

NOU (2018:13). Voksne i grunnskole- og videregående opplæring - Finansiering av livsopphold. Hentet fra https://www.regjeringen.no/no/dokumenter/nou-2018-13/id2620876/sec1. 
Orloff, A. (1993). Gender and the Social Rights of Citizenship: The Comparative Analysis of Gender Relations and Welfare States. American Sociological Review, 58(3), 303-328.

Peters, B. G. (2019). Institutional theory in political science: The new institutionalism. Fourth edition. Cheltenam, UK: Edward Elgar Publishing.

Pfau-Effinger, B. (2005). Culture and welfare state policies: Reflections on a complex interrelation. Journal of Social Policy, 34(1), 3-20.

Pinto, K. M., \& Coltrane, S. (2009). Divisions of labor in Mexican origin and Anglo families: Structure and culture. Sex Roles, 60(7-8), 482-495.

Portes, A., \& Rivas, A. (2011). The adaptation of migrant children. The future of children, 21(1), 219-246.

Portes, A., \& Rumbaut, R. G. (2001). Legacies: The story of the immigrant second generation: Univ of California Press.

Portes, A., \& Zhou, M. (1993). The new second generation: Segmented assimilation and its variants. The annals of the American academy of political and social science, 530(1), 74-96.

Prieur, A. (2002). Gender remix: On gender constructions among children of immigrants in Norway. Ethnicities, 2(1), 53-77.

Reeskens, T., \& Van Oorschot, W. (2015). Immigrants' attitudes towards welfare redistribution. An exploration of role of government preferences among immigrants and natives across 18 European welfare states. European sociological review, 31(4), 433-445.

Roder, A., \& Mühlau, P. (2014). Are They Acculturating? Europe's Immigrants and Gender Egalitarianism. Social Forces, 92(3), 899-928.

Rubery, J., Earnshaw, J., Marchington, M., Cooke, F. L., \& Vincent, S. (2002). Changing organizational forms and the employment relationship. Journal of Management Studies, 39(5), 645-672.

Rubin, J., Rendall, M. S., Rabinovich, L., Tsang, F., van Oranje-Nassau, C., \& Janta, B. (2008). Migrant women in the European labour force. Current situation and future prospects. Cambridge: RAND Europe.

Rueda, D., Wibbels, E., \& Altamirano, M. (2015). The Origins of Dualism. In H. Kriesi, H. Kitschelt, P. Beramendi, \& S. Häusermann (Eds.), The Politics of Advanced Capitalism (pp. 89-111). Cambridge: Cambridge University Press.

Röder, A. (2014). Explaining religious differences in immigrants' gender role attitudes: the changing impact of origin country and individual religiosity. Ethnic and Racial Studies, 37(14), 2615-2635

Röder, A., \& Mühlau, P. (2011). Discrimination, exclusion and immigrants' confidence in public institutions in Europe. European Societies, 13(4), 535-557.

Röder, A., \& Mühlau, P. (2012). Low expectations or different evaluations: What explains immigrants' high levels of trust in host-country institutions? Journal of Ethnic and Migration Studies, 38(5), 777792.

Rønsen, M., \& Kitterød, R. H. (2015). Gender-equalizing family policies and mothers' entry into paid work: recent evidence from Norway. Feminist Economics, 21(1), 59-89.

Sainsbury, D. (2019). Policy constructions, immigrants' social rights and gender: The case of Swedish childcare policies. Journal of European Social Policy, 29(2), 213-227.

Sandvik, L., \& Gram, K. H. (2019). Kontantstøtte blant innvandrere. Oslo/Kongsvinger: Statistisk sentralbyrå. Lastet ned fra https://www.ssb.no/sosiale-forhold-og-kriminalitet/artikler-ogpublikasjoner/laveste-andel-mottakere-pa-20-ar

Scott, J. W. (1993). The woman worker. In G. Fraisse, M. Perrot, \& P. Schmitt Pantel (Eds.), A History of Women in the West. Vol. IV. Emerging Feminisms from Revolution to World War. (Vol. 4, pp. 399427). Cambridge: The Belknap Press of Harward University Press.

Scott, R. W. (2014). Institutions and organizations: Ideas, Interests, and Identities. Fourth edition. Sage Publications.

Seale, C., Gobo, G., Gubrium, J. F., \& Silverman, D. (2004). Qualitative research practice: Sage publications.

Smelser, N. J. (1998). The rational and the ambivalent in the social sciences. American Sociological Review, 63, 1-16.

Soss, J., \& Schram, S. F. (2007). A public transformed? Welfare reform as policy feedback. American political science review, 101(1), 111-127.

Standing, G. (2011). The precariat: The dangerous new class. London/United Kingdom:Bloomsbury Academic.

Steiber, N., \& Haas, B. (2012). Advances in explaining women's employment patterns. Socio-Economic Review, 10(2), 343-367.

Stier, H., \& Lewin-Epstein, N. (2003). Time to work: A comparative analysis of preferences for working hours. Work and occupations, 30(3), 302-326. 
Stone, J., \& Fernandez, N. C. (2008). How Behavior Shapes Attitudes. Cognitive Dissonance Processes. In W. D. Crano \& R. Prislin (Eds.), Attitudes and attitude change. New York, London: Psychology Press, Taylor \& Francis Group.

Stortingsmelding 74 (1979/80). Om innvandrere i Norge. Retrieved from https://www.stortinget.no/no/Saker-ogpublikasjoner/Stortingsforhandlinger/Lesevisning/?p=197980\&paid=3\&wid=f\&psid=DIVL134\&s=False\&pgid=f_0154.

Streeck, W., \& Thelen, K. A. (2005). Beyond continuity: Institutional change in advanced political economies. Oxford: Oxford University Press.

Svallfors, S. (2010). Policy feedback, generational replacement, and attitudes to state intervention: Eastern and Western Germany, 1990-2006. European Political Science Review, 2(1), 119-135.

Söhn, J. (2013). Unequal welcome and unequal life chances: How the state shapes integration opportunities of immigrants. European Journal of Sociology/Archives Européennes de Sociologie, 54(2), 295-326.

Taylor-Gooby, P. (2008). Reframing social citizenship. Oxford Scholarship Online. DOI:10.1093/acprof:oso/9780199546701.001.0001

Tønnessen, M. (2014). Fruktbarhet og annen demografi hos innvandrere og deres barn født i Norge. Oslo/Kongsvinger: Statistisk sentralbyrå.

Van Berkel, R., \& Knies, E. (2016). Performance management, caseloads and the frontline provision of social services. Social Policy \& Administration, 50(1), 59-78.

Van Berkel, R., Caswell, D., Kupka, P., \& Larsen, F. (Eds.). (2017). Frontline delivery of welfare-to-work policies in Europe: Activating the unemployed. New York and London: Routledge.

Vrålstad, S., \& Wiggen, K. S. (2017). Levekår blant innvandrere i Norge 2016. Rapporter 2017/13, Oslo/Kongsvinger: Statistisk sentralbyrå.

Wallander, L., \& Molander, A. (2014). Disentangling professional discretion: A conceptual and methodological approach. Professions and Professionalism, 4(3), 1-19.

Wielers, R., Münderlein, M., \& Koster, F. (2013). Part-time work and work hour preferences. An international comparison. European sociological review, 30(1), 76-89.

Williamson, D. L., Choi, J., Charchuk, M., Rempel, G. R., Pitre, N., Breitkreuz, R., \& Kushner, K. E. (2011). Interpreter-facilitated cross-language interviews: a research note. Qualitative research, 11(4), 381-394.

Wright, S. (2012). Welfare-to-work, Agency and Personal Responsibility. Journal of Social Policy, 41(2), 309-328.

Zacka, B. (2017). When the state meets the street. Public service and moral agency. Cambridge, M and London, England: Harvard University Press.

Østbakken, K. M., Reisel, L., Schøne, P., Barth, E., \& Hardoy, I. (2017). Kjønnssegregering og mobilitet i det norske arbeidsmarkedet. ISF-rapport 2017:9, Oslo: Institutt for samfunnsforskning.

Østerberg, D. (1984). Sosiologiens nøkkelbegreper og deres opprinnelse. Oslo: Cappelen forlag.

$\emptyset$ verbye, E., \& Stjern $\varnothing$, S. (2012). Arbeidsmotivasjon, arbeidslinje og velgerdsstat. I S. Stjern $\varnothing$ \& E. Øverbye (red.), Arbeidslinja. Arbeidsmotivasjon og velferdsstaten. Oslo: Universitetsforlaget. 
Artikkel 1. Verdier på vandring. Arbeidsdeling i innvandrede familier 



\title{
Verdier på vandring
}

\author{
Arbeidsdeling i innvandrede familier
}

\author{
Hanne C. Kavli
}

Våren 2009 fikk daværende familie- og likestillingsminister Anniken Huitfeldt overlevert stortingsmeldingen om menn, mannsroller og likestilling. Hun benyttet anledningen til å gå ut i VG med en oppfordring til innvandrermenn om å stå fram som gode eksempler for sønnene sine når det gjelder likestilling. «De må delta $i$ husarbeidet på lik linje med kvinnene. De må vaske opp, skifte bleier, gå med barnevogn og hente i barnehagen,» uttalte hun, og fortsatte: «Hvis man vil at barna skal lykkes i Norge, må man loere dem likestilling i praksis.» (VG 11. mai 2009). Utspillet ble møtt med sterke reaksjoner, blant annet fra Venstre-politiker Abid Raja og Arbeiderparti-politiker Aslam Ahsan, men ministerens virkelighetsbeskrivelse fikk stå uimotsagt. Kritikken handlet om at kjønnslikestillingens utfordringer lå andre steder enn i fordelingen av husarbeidet (Raja), at menn allerede arbeidet lange dager for å forsørge familien, og at det var lite rimelig at de skulle pålegges flere oppgaver (Ahsan), eller at ministeren her beveget seg altfor langt inn i den private sfæren (Fremskrittspartiet v/Siv Jensen). Daværende generalsekretær i Islamsk Råd, Shoaib Sultan, plukket imidlertid opp tråden et par dager senere og etterlyste dokumentasjon (P4-nyhetene, 15. mai 2009). Hvor ulik praksis har egentlig norske og forskjellige grupper av innvandrede familier når det gjelder hus-, lønns- og omsorgsarbeid?

I dette kapitlet er temaet kjønnslikestilling blant utvalgte grupper av innvandrere, belyst gjennom arbeidsdelingen i familien. Jeg ser nærmere på hvordan innvandrede familier fordeler hus-, lønns- og omsorgsarbeid og på holdninger til hvordan dette arbeidet bør fordeles. I tillegg analyseres dissonans mellom holdninger og praksis 
i ulike landgrupper, et tema som så langt er lite utforsket. Og jeg diskuterer hvordan samspillet mellom personlige egenskaper, velferdsstat og arbeidsmarked kan påvirke både omfang av, og type dissonans. Analysene bygger på intervjuer av 1110 personer fra Norge, Pakistan, Iran, Irak og Vietnam, og er støttet av registerdata på individnivå. Innvandrere i Norge har bakgrunn fra mer enn 200 ulike land. Hvem vi retter søkelyset mot, vil påvirke hvilken del av historien om «innvandrere i Norge» som blir fortalt. Jeg vil derfor innledningsvis beskrive landgruppene som inngår i materialet, og hvordan veien inn i Norge kan ha preget veien videre. ${ }^{1}$

\section{Veier til Norge - flukt, arbeid og familie}

Hvordan en kom til Norge, når, og med hvem, preger veien videre på ulike måter. Innsatsen det offentlige setter inn overfor nyankomne, påvirkes av hvilke behov myndighetene oppfatter at nykommerne har. I 1980-årene ble behovene i hovedsak definert som bolig, inntektssikring og hjelp til å lære norsk. Etter hvert som det ble klart at denne politikken ikke oppnådde sine målsettinger om integrering i arbeids- og samfunnsliv, fant det sted en gradvis omlegging av integreringspolitikken (Djuve og Kavli 2007). Flyktninger møter i dag et 2-3 år langt, obligatorisk, fulltids introduksjonsprogram. ${ }^{2}$ Målet er lønnet arbeid eller ordinær utdanning, økonomisk selvstendighet og bedre forutsetninger for generell samfunnsdeltakelse. I motsetning til sosialhjelp er stønaden i introduksjonsprogrammet individuell og rettighetsbasert, ikke husholdsbasert og behovsprøvd. Modellen ble utformet slik for å være så lik vanlig lønn som mulig, men også for å sørge for at kvinner hadde et like sterkt økonomisk insentiv for å delta som menn (NOU 2001: 20, punkt 10.2). Deltakerne får tett oppfølging fra velferdsapparatet. I hvilken grad arbeidsdelingen i hjemmet tas opp i samtalene mellom deltakere og programrådgivere, varierer, men hvis en svært skjev arbeidsdeling påvirker kvinners muligheter for å følge opp programmet, er det eksempler på at situasjonen tas opp både med ham og henne (Djuve, Kavli og Hagelund 2012). Arbeidsinnvandrere og deres familier kom og kommer til Norge under andre forutsetninger enn flyktninger, og møter et offentlig apparat som er langt mindre omfattende. Integreringsapparatet er i hovedsak bygget opp rundt de som har rett og plikt til kvalifisering, det vil si nyankomne flyktninger og andre med behov for inntektssikring. Personer som

1 Stor takk til bokens redaktører og øvrige forfattere for gode innspill, og til Barne-, likestillingsog inkluderingsdepartementet som har finansiert arbeidet. Takk også til Anne Britt Djuve, Tale Hellevik, Håkon Kavli, Heidi Nicolaisen og Kristian R. Tronstad for kreative spørsmål.

2 Introduksjonsloven ble innført 1. september 2004 (Kavli, Hagelund og Bråthen 2007). 
innvandrer til Norge gjennom familiedannelse eller familiegjenforening, skal i utgangspunktet være forsørget. De kommer derfor ikke i kontakt med det offentlige før de eventuelt tar initiativ selv.

Innvandrerne i denne undersøkelsen har kommet til Norge gjennom ulike kanaler. Innvandrere fra Irak er nesten utelukkende flyktninger eller familiegjenforente med flyktninger, og de fleste har kort botid i Norge (Henriksen 2007). Mange ble derfor introdusert for Norge gjennom introduksjonsprogrammet. Iranere kom i stor grad som flyktninger i kjølvannet av revolusjonen i 1979. De har dermed vært i Norge lenger og har ikke fått en så omfattende oppfølging av det offentlige som irakerne. Det har heller ikke vietnamesiske flyktninger, der om lag to av tre har bodd i Norge i mer enn 15 år. De første pakistanerne kom til Norge som arbeidsinnvandrere i 1970-årene. Etter den såkalte innvandringsstoppen i 1976 har innvandringen fra Pakistan vært dominert av familieinnvandring (ved inngåelse av ekteskap) eller familiegjenforening. Botiden er i gjennomsnitt høy, og 6 av 10 har bodd i Norge i over 15 år. Den stadige fornyelsen av bånd til hjemlandet gjennom familiedannelse fører samtidig til at mange unge par er sammensatt av én ektefelle med lang botid og én med kort. Familieinnvandrere er ikke i målgruppen for introduksjonsprogrammet, men i den grad de får behov for økonomisk bistand fra det offentlige, møter de på lik linje som andre ulike typer av krav om deltakelse i kvalifisering.

Innvandrere fra Iran, Irak, Pakistan og Vietnam har dermed møtt den offentlige diskursen om kjønnslikestilling og integrering i ulik grad, på ulik måte og over et ulikt tidsrom. Der noen allerede ved ankomst ble møtt med velferdsstatens krav eller forventninger om at alle - kvinner og menn - skal delta i fulltids kvalifisering med lønnet arbeid som mål, har andres møte med Norge vært sterkere preget av familiens forventninger og ønsker, eller arbeidslivets krav og betingelser.

\section{Rammer for arbeidsdeling i familien}

Litteraturen om arbeidsdelingen hjemme mellom menn og kvinner tar ofte utgangspunkt i hvordan individuelle og familierelaterte faktorer påvirker hvem som gjør hva. Disse forklaringene er blant annet knyttet til forhold som hans og hennes relative ressurser, forhandlinger og tilgjengelig tid, samt holdninger og interesser (Knudsen og Wærness 2008: 98-99, Geist 2005: 24-25, Coltrane 2000: 1213). Teorier om relative ressurser bygger typisk på at par inngår i ulike former for forhandlinger om hvem som skal gjøre hva i familien. Fordi mannen ofte har den høyeste inntekten (eller den beste utsikten til å gjøre karriere), vil han gjøre mindre husarbeid enn henne. Andre legger større vekt på tilgjengelig tid, og hvordan allokering 
av tid skjer innenfor rammen av hva som gir størst utbytte for familien som helhet. Husarbeidet gjøres av den som har best tid til å gjøre det. Begge tilnærmingene berører relevansen av hvem som deltar i arbeidsmarkedet, hvor mye, og hva familien samlet sett tjener på det både nå og på lengre sikt. Dette regnestykket påvirkes ikke bare av trekk ved individene og familiene, men også av velferdsstatens utforming og arbeidsmarkedts organisering. Jeg skal ikke teste relevansen av de ulike forklaringsmodellene her, men bruke dem som et utgangspunkt for å belyse trekk ved de ulike landgruppene i materialet som kan påvirke arbeidsdelingen i familien. Søkelyset rettes mot utdanning, fruktbarhet og arbeid. ${ }^{3}$

Kvinner har (sett under ett) både mindre utdanning og arbeidserfaring enn menn når de innvandrer til Norge. De stiller dermed dårligere rustet enn menn med tanke på å skaffe lønnet arbeid i Norge. Oversiktsbildet skjuler samtidig store variasjoner mellom landgruppene. Blant iranske innvandrere hadde en høy andel både mye utdanning og arbeidserfaring ved innvandringen. Så mange som 8 av 10 iranske kvinner hadde et yrke i Iran. Blant vietnamesere manglet nesten halvparten grunnskole både blant kvinner og menn, og sysselsettingen var lenge svært lav. Over 7 av 10 kvinner hadde imidlertid yrkeserfaring fra Vietnam, og mange tok senere noe utdanning i Norge. Blant pakistanske og irakiske innvandrere har kvinner gjennomgående lavere utdanning enn menn, de har i liten grad tatt videre utdanning i Norge, og bare 2 av 10 kvinner hadde et yrke før de kom til Norge. Kvinner fra Irak og Pakistan er også blant de som får flest barn i snitt, henholdsvis 4,3 og 3,2 barn per kvinne. Kvinner med bakgrunn fra Iran og Vietnam har derimot et fruktbarhetsmønster som ligger tett opp mot resten av befolkningen, med henholdsvis 1,6 og 2 barn per kvinne (Hurlen Foss 2006).

Kvinners yrkesaktivitet er lavere enn menns, uansett hvilken landgruppe vi studerer. Men hvor mye lavere, og hvor lavt, varierer. I befolkningen sett under ett, er 69 prosent av alle kvinner mellom 15 og 74 år sysselsatt, om lag 6 prosentpoeng færre enn blant menn. Kvinner jobber også oftere deltid enn menn. Blant iranere og vietnamesere i Norge er henholdsvis 56 og 62 prosent av kvinnene i lønnet arbeid, om lag 6 prosentpoeng færre enn blant menn av samme opprinnelse. Lavest sysselsetting, både blant kvinner og menn, finner vi blant innvandrere fra Pakistan og Irak. Her er også kjønnsforskjellene store. Yrkesaktiviteten blant innvandrede kvinner fra Irak og Pakistan er henholdsvis 36 og 32 prosent - 19 og 31 prosentpoeng lavere enn blant menn. (Statistisk sentralbyrå 2010).

3 Dersom ikke annet er oppgitt, er tallene fra Statistisk sentralbyrås levekårsundersøkelse blant innvandrere (Henriksen 2010). 
I forhandlingsteoretiske termer vil en, ut fra disse tallene, noe enkelt postulere at det ofte vil lønne seg for familien at kvinnen tar en større del av arbeidet hjemme enn mannen. Flere har imidlertid også pekt på betydningen av kjønnsroller, verdier og holdninger. Oppfatninger om hva som er den beste arbeidsdelingen mellom menn og kvinner kan være en robust del av en persons og et samfunns kulturelle arv, blant annet fordi synet på hvilke oppgaver som tilfaller kvinner (og menn) kan være nært knyttet til religiøse leveregler (Huntington 1993, Modood mfl. 1997). Dette løftes ofte fram i debatten om kjønnslikestilling blant innvandrede familier. Variasjoner i holdinger bør derfor med i analysen av variasjoner i familiepraksis. Samtidig er det viktig at ikke kulturforklaringene overskygger kunnskap om forskjeller i muligheter, eller (som Nadim drøfter i kapittel 13 i denne boka) behandler verdier og kulturer som noe enhetlig og statisk.

Det er vanlig å anta at verdier etableres under oppveksten, nærmere bestemt i 15-20-årsalderen (Hellevik 2002: 4). ${ }^{4}$ I hvilken grad verdiene endres over livsløpet, og hva som skaper slik endring, er det ulike oppfatninger om. Ingelhart (1977) hevdet i boken The Silent Revolution at verdiene endres lite etter ungdomstiden og dermed er et generasjonsfenomen. Det som preger deg under oppveksten, fortsetter å legge føringer for verdiene dine også senere i livet. Andre hevder at både den enkeltes livsfase (aldring, eller skifte av sosiale roller), eksponering for nye praksiser, og betydningsfulle hendelser $i$ samtiden kan lede til at den enkelte utvikler nye verdier (Hellevik 2002, Bolzendahl og Myers 2004). De fleste legger likevel til grunn at verdiendring, både på individ- og samfunnsnivå, tar tid. ${ }^{5}$

\section{Om holdninger i praksis}

Oppslutningen om kjønnslikestilling har økt markant over tid, både i Norge og i store deler av Europa (Knutsen og Wærness 2001, Ingelhart og Norris 2003). Praksis ser imidlertid ut til å henge noe etter endringene i holdninger, og kvinner har fortsatt større ansvar hjemme enn menn (Bernhardt mfl. 2008, Kitterød 2004). Dette er trolig noe av årsaken til at forskning om sammenhengen mellom holdninger og praksis på likestillingsområdet i stor grad har oppholdt seg ved det Bühlman mfl. (2010) beskriver som et paradoksalt sammenfall mellom likestilte verdier og en

4 Jeg bruker verdi- og holdningsbegrepet deskriptivt, som et bilde på hva personer oppfatter som $ø$ nskelig. Dette i motsetning til en normativ forståelse av begrepet, som tar opp hva som er verdt å ønske seg (Hellevik 2002).

5 Det pågår en vitenskapsteoretisk og metodisk debatt knyttet til målingen av holdninger og verdier - jeg kommenterer den kort i metodekapitlet, men vil i analysen ha som utgangspunkt at holdninger kan måles, og at de kan belyse atferd. 
lite likestilt praksis. Sammenfallet mellom holdninger og praksis påvirkes både av familiefase og av sosiale strukturer i det samfunnet paret er en del av. Unge heteroseksuelle par i Europa rapporterer i overveiende grad om både kjønnslikestilte holdninger og praksiser før de får barn. Etter at de er blitt foreldre, oppstår det større spenninger mellom (fortsatt) likestilte holdninger, men mer kjønnstradisjonelle praksiser. Hvor omfattende og vedvarende disse spenningene er, varierer mellom ulike typer av velferdsstater og velferdsordninger. I de sosialdemokratiske velferdsstatene er spenningene mindre framtredende og oftere reversible enn i liberale, konservative og postkommunistiske velferdsregimer. Forfatterne setter dette i sammenheng med familiepolitikken. Sannsynligheten for å gjenoppta en likestilt praksis etter at småbarnsfasen er over, er større i land med god og rimelig barnehagedekning og lange foreldrepermisjoner enn $\mathrm{i}$ land uten slike tilbud (Ibid.).

Usdansky (2011), som gjennomfører en metaanalyse av amerikanske studier, bringer inn et klasseperspektiv i analysen av (det manglende) sammenfallet mellom holdning og praksis på likestillingsområdet. Hun viser hvordan den normative oppslutningen om likestilling er mer utbredt i middelklassen enn i arbeiderklassen, og argumenterer for at sosiale strukturer fungerer som sterke motkrefter til familienes holdninger. Kombinasjonen av et krevende arbeidsliv og såpass høye lønninger at det er mulig å greie seg på én, eller halvannen, inntekt, trekker den ellers likestillingsorienterte middelklassen i retning av en mer tradisjonell arbeidsdeling fordi kvinner reduserer tiden i lønnet arbeid for å få familielivet til å fungere. I arbeiderklassen, der lønningene er lavere, leder knapphet på penger kombinert med en oppfatning av at det er rimelig å dele på ansvaret hjemme når begge arbeider like mye, i retning av en mer likestilt arbeidsdeling. Usdansky mener derfor at en kombinasjon av egenskaper ved familiene og trekk ved arbeidsmarkedet skyver familier med høy utdanning og likestilte holdninger i retning av en tradisjonell praksis, og familier med lav utdanning og tradisjonelle holdninger i retning av en likestilt praksis.

Også forskjellene mellom innvandrere og etniske minoriteter på den ene siden og majoritetsbefolkningen på den andre kan leses i et klasseperspektiv. Pinto og Coltrane (2009) mener forskningen om arbeidsdelingen i minoritetsfamilier har lagt for stor vekt på kulturelle forklaringer på bekostning av strukturelle forhold. De finner at amerikanske familier av meksikansk opprinnelse har et mer kjønnstradisjonelt syn på arbeidsdelingen mellom menn og kvinner enn angloamerikanske familier. Praksis er imidlertid likere enn holdningene skulle tilsi. Pinto og Coltrane forklarer dette med at familiene responderer på strukturelle rammer (tilgjengelig tid og relative ressurser) på samme vis uavhengig av opprinnelse. Dette bryter ifølge forfatterne med tidligere antakelser om at partenes relative ressurser har mindre 
betydning blant minoritetene fordi sterke kulturelle verdier trekker i retning av en kjønnstradisjonell arbeidsdeling. Vanskene med å forsørge en familie på én, eller halvannen, inntekt innenfor det segmentet av arbeidslivet der en overvekt av minoritetene i USA befinner seg, framstår som den mest tungtveiende strukturelle forklaringen på at ansvaret for både husarbeid og forsørgelse er delt i større grad enn det holdningene skulle tilsi.

Strukturene rundt familien, som arbeidslivets organisering og velferdsstatens utforming, kan både forsterke og svekke betydningen av de individuelle egenskapene som trekker i retning av en mer eller mindre likestilt arbeidsdeling mellom menn og kvinner (Geist 2005). Den norske velferdsstatens familiepolitikk har en komparativt sett klar ambisjon om å fremme toinntektsfamilien og likestilling mellom menn og kvinner. Lang svangerskapspermisjon med høy lønnskompensasjon, fedrekvote og subsidierte barnehager med tilnærmet full dekning er sentrale virkemidler. Norge kjennetegnes både av en befolkning som i høy grad støtter opp om likestilling i hjemmet, og en velferdspolitikk som komparativt sett gjør likestilte holdninger lettere å leve ut. To norske studier finner likevel at holdninger ikke sammenfaller med praksis knyttet til likestilling hos om lag halvparten av informantene (Kjelstad og Lappegård 2012, Hellevik og Hellevik 2012). Begge studier viser at dissonans (holdninger og praksis er ulike) er omtrent like vanlig blant kvinner og menn. Men blant kvinner handler dissonansen oftest om at praksis er mindre likestilt enn holdningene, mens menn oftere beskriver praksis som mer likestilt enn holdningene. Innvandrere til Norge eksponeres for en sterk likestillingsretorikk både i offentlig debatt og (om enn i ulik grad) gjennom familie- og integreringspolitikken. Men hvor utbredt er dissonans i ulike deler av den innvandrede befolkningen i Norge og hva slags dissonans er det snakk om?

\section{Data og undersøkelsesopplegg}

Analysene bygger på en spørreundersøkelse blant om lag 1500 personer i alderen 20 til 55 år. Fem tilfeldige utvalg av personer med bakgrunn fra Iran, Irak, Vietnam, Pakistan og Norge ble trukket fra Folkeregisteret. ${ }^{6}$ Utvalgene ble trukket slik at det var en jevn fordeling av kvinner og menn i alle fem underutvalg. Analysene er avgrenset til 1110 personer som lever i par (gifte eller samboere). Utvalget består av individer, men informantene gir også noe informasjon om sin partner. I tillegg er det ved hjelp av registerdata koblet på omfattende informasjon både om informan-

6 «Innvandrer» er her definert som en person som er født i utlandet av to utenlandskfødte foreldre. 
tene og deres partnere. Spørreskjemaet ble oversatt til informantenes morsmål, og intervjuene foregikk på det språket informanten foretrakk. Dermed inkluderes personer som på grunn av manglende norskferdigheter ellers ikke ville hatt muligheter til å delta, og risikoen for misforståelser reduseres. Spørreskjemaet ble gjennomgått sammen med de flerspråklige intervjuerne, for å sikre at oversettelsene var i tråd med de norske formuleringene, og at betoningen i de normative påstandene var lik.

Svarprosenten varierer mellom 30 og 38 prosent. Hovedkilden til frafall var at det ikke ble oppnådd kontakt med informanten - en mer vanlig frafallsgrunn blant innvandrere enn i befolkningen for øvrig (Djuve mfl. 2009). Svartilbøyeligheten (andel intervjuer blant dem det ble oppnådd kontakt med) varierer mellom 50 og 74 prosent i de ulike landgruppene. Det er gjennomført en frafallsanalyse med utgangspunkt i registerdata som er koblet til surveyundersøkelsen på individnivå. Den viser, i likhet med det som er vanlig i intervjuundersøkelser, en viss overrepresentasjon av personer med høy utdanning og personer i lønnet arbeid. I det irakiske og vietnamesiske utvalget er henholdsvis kvinner og menn noe overrepresentert. I tillegg er det blant innvandrerne en underrepresentasjon i den yngste aldersgruppen (20-29 år). Disse skjevhetene er så langt som mulig tatt hensyn til i analysene. Intervjuerkorpset og forskerne hadde tett kontakt underveis. I tillegg ble informasjon og kommentarer informantene ga, notert i en egen logg. Vi gjennomførte fokusgrupper og individuelle intervjuer blant pakistanske og norske småbarnsforeldre, der deltakerne fikk presentert hovedfunn fra de kvantitative analysene som deretter ble drøftet. (Se Kavli og Nadim 2009 for en detaljert gjennomgang.)

Samsvar, eller mangel på samsvar, mellom holdninger og handlinger er et viktig tema innenfor samfunnsvitenskapen både vitenskapsteoretisk og metodisk. Jon Elster (1983) påpekte hvordan vi ikke alltid har klare preferanser, men også hvordan vi ubevisst kan tilpasse preferansene våre til hva vi tror vi kan oppnå. Svar som er strategiske, enten for å tilfredsstille et indre behov for konsistens hos den enkelte (Hochschild 1987) eller for å unngå ubehaget ved å framstå i et ufordelaktig lys (Haavind 1984), er det vanskelig å ta fullt ut hensyn til både i kvalitative og kvantitative undersøkelser. Informanter med lang botid i Norge eller et intensivt kvalifiseringsprogram bak seg vil ha god kjennskap til de normative føringene om kjønnslikestilling i Norge. Under kvalitative intervjuer ga enkelte uttrykk for at de var lei av hvordan innvandreres familiepraksiser blir framstilt i mediene. $\AA$ beskrive en kjønnsdelt arbeidsdeling var derfor liten vits i - det ville uansett fortolkes feil og i siste instans brukes som nok et argument for å kritisere innvandrere. Dersom det har vært en slik tendens blant informantene, vil den trekke i retning 
av mindre forskjeller mellom norske og innvandrede informanter. På den andre siden løftet også flere fram nettopp en kjønnsdelt arbeidsdeling hjemme som noe de var spesielt stolte av - og det er dermed ikke gitt hvilken retning eventuell strategisk svaring vil ha tatt.

Det som derimot er godt dokumentert, er at holdninger og praksis ikke alltid sammenfaller. Hellevik og Hellevik (2012: 162) drøfter mulige årsaker til at de ikke finner et sterkere sammenfall mellom holdninger og praksis. En hypotese er at holdningene som er målt, ikke dreier seg om fordelingen av hus- og omsorgsarbeid, men om et mer generelt syn på kjønnsroller. Dette er en mindre utfordring i foreliggende undersøkelse, der sammenfallet mellom holdninger og praksis måles i likere spørsmålspar. ${ }^{7}$ I den grad holdningene er ulike, er det imidlertid en utfordring at begge undersøkelsene måler holdningen til bare én av personene i paret. Den andre kan ha en annen holdning som kan påvirke praksis. Til sist er rapportering av hvem som gjør hva hjemme, subjektivt. Begge parter har en tendens til å overdrive egen innsats på bekostning av partnerens. I hvilken grad en slik bias er til stede blant ulike grupper av innvandrere, bør holdes åpent fram til det er nærmere studert. Kanskje er «bias-fellen» større blant personer med bakgrunn fra land som har vært gjennom en overgang fra tradisjonelle til mer egalitære holdninger, enn blant personer med bakgrunn fra land som i større grad domineres av mindre kjønnsegalitære holdninger. En utfordring som er mer spesifikk for mitt materiale, er at vi mangler informasjon om hus- og forsørgerarbeid utføres av tredjepart, for eksempel innenfor en storfamilie. Slike familiekonstellasjoner er noe mer vanlige blant innvandrere fra Pakistan og Vietnam enn i de andre landgruppene i undersøkelsen, og kan dermed føre til at vurdering av om det er han eller henne som gjør mest, blir mindre treffende.

\section{Hvem gjør hva hjemme? Fordeling av arbeid i familien}

Spørsmål om kjønnsroller og likestilling knyttes gjerne til fordelingen av tre sett av oppgaver: husarbeid, omsorgsarbeid og lønnsarbeid. Det vanligste, i alle landgrupper i vårt materiale, er å dele ansvaret for disse oppgavene temmelig likt (Kavli og Nadim 2009). Samtidig varierer det i hvilken grad kvinner og menn er involvert i de ulike sidene ved det å drive en familie. Informantene har svart på spørsmål om hvordan de fordeler husarbeid, vedlikeholdsarbeid, omsorgsarbeid

7 Det er ikke noe tilsvarende spørsmålspar som omhandler omsorgsarbeid, og de senere analysene av konsistens eller dissonans i holdning og praksis omfatter derfor bare hus- og forsørgerarbeid. 
og ansvaret for familiens økonomi, og har vurdert om det er de selv som gjør mest, om det er partneren som gjør mest, eller om arbeidet deles likt. Figurene 12.1.1 til 12.1.5 viser hvor stor andel i hver landgruppe som sier at kvinnen eller mannen ikke er involvert i totalt 7 ulike oppgaver knyttet til familien. ${ }^{8}$ Figurene er formet som edderkoppnett, med separate tråder for kvinner og menn. Jo lenger vekk fra sentrum i nettet tråden befinner seg, jo større er andelen som ikke er involvert i den oppgaven som måles.

Figur 12.1.1-12.1.5 Prosentandel som IKKE er involvert i ulike oppgaver i og rundt hjemmet, etter kjønn* og landgruppe. Gjennomsnitt av menn og kvinners svar**

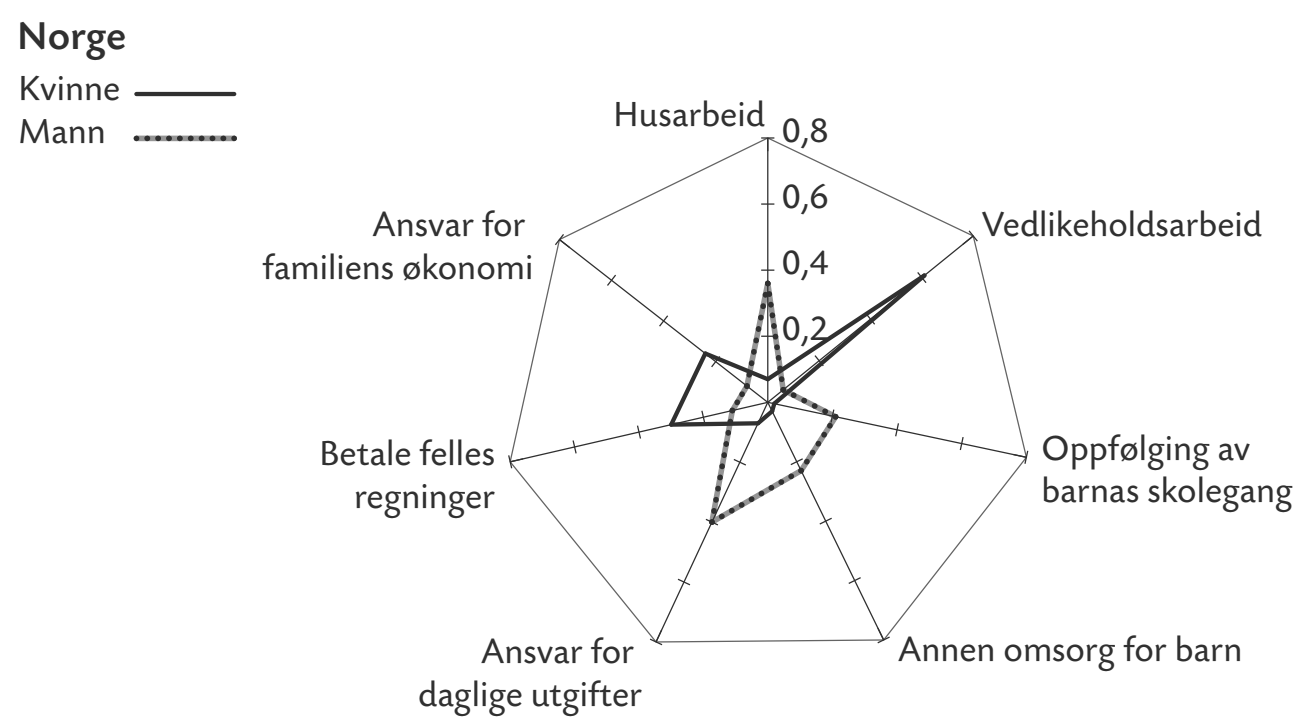

\section{Pakistan}

Kvinne Mann

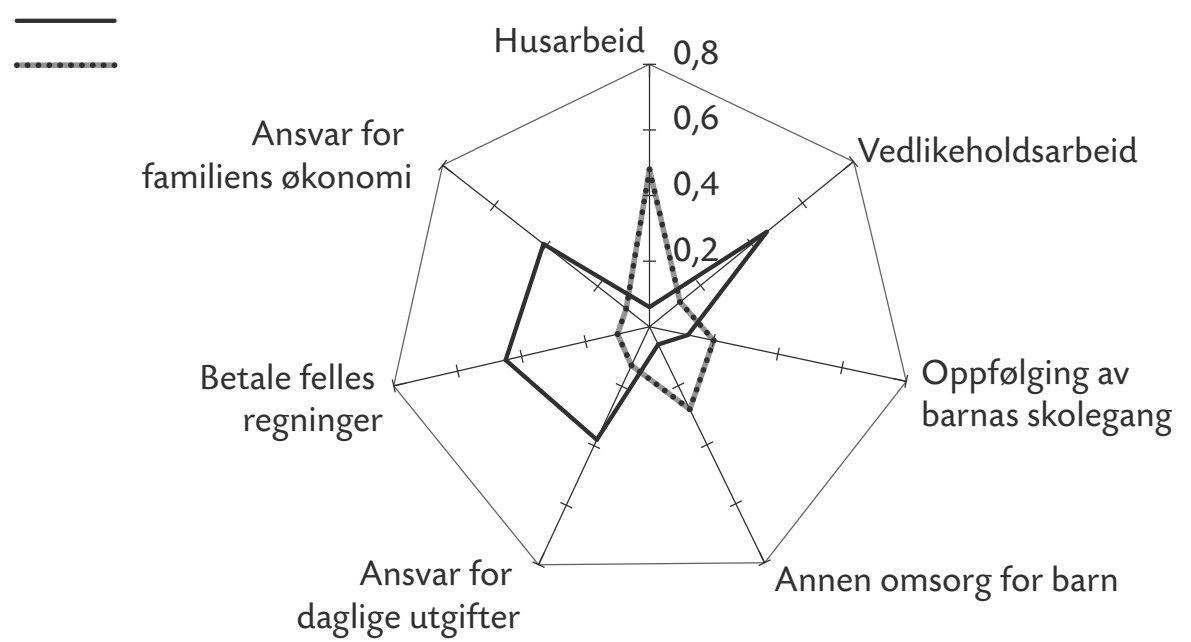

8 For presise spørsmålsformuleringer, se Kavli og Nadim 2009. 

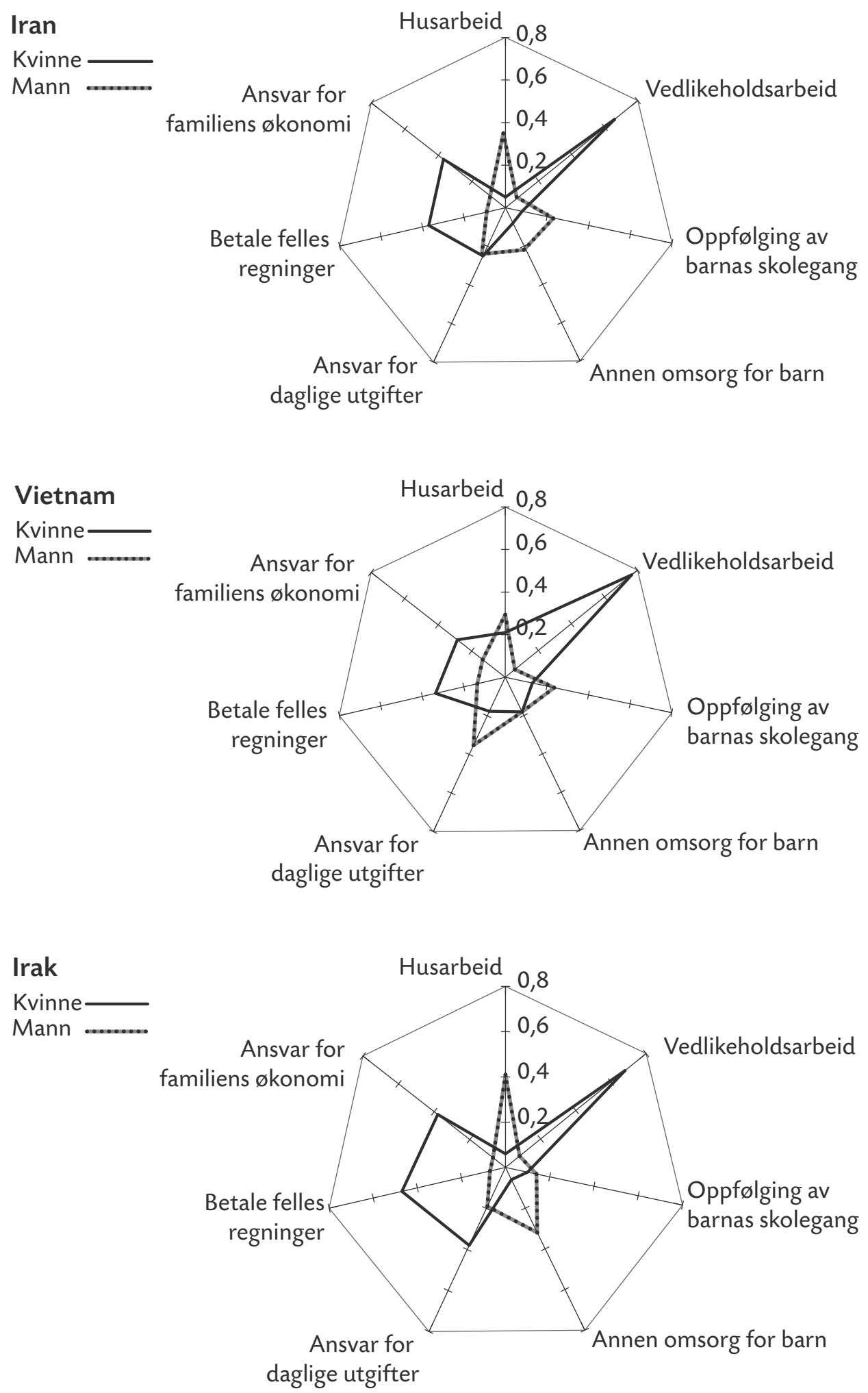

* Kjønnsfordelingen er basert på både menns og kvinners svar om fordelingen av oppgaver i eget hjem. Informasjon om menns involvering (for eksempel) i husarbeidet er dermed basert både på menns beskrivelse av egen rolle og kvinners beskrivelse av sine partneres rolle.

** N: 1110 (NOR: 198, IRN: 194,IRQ: 209, VIET: 238, PAK:271) 
Likhetene mellom landgruppene i materialet er ofte mer påfallende enn forskjellene. Sett under ett er menn mindre involvert enn kvinner i husarbeid, mens kvinner er mindre involvert enn menn i vedlikeholdsarbeid og i det overordnede ansvaret for familiens økonomi. Selv om utslagene er mindre når det gjelder omsorgsarbeid, er hovedmønsteret også der at menn oftere enn kvinner er lite involvert.

Samtidig varierer omfanget av en kjønnet arbeidsdeling i de fem landgruppene. Variasjonen kommer klarest fram i de tre spørsmålene om familiens økonomi. Andelen familier der kvinnen ikke har et medansvar for familiens samlede økonomi, er nesten dobbelt så høy blant irakere, vietnamesere og pakistanere enn blant norske og iranske informanter. Når det gjelder daglige utgifter, for eksempel å handle mat eller å kjøpe presanger, er kvinner oftere involvert enn menn. Blant pakistanske og irakiske familier svarer imidlertid fire av ti at kvinnen heller ikke er involvert i å betale de daglige utgiftene. Arbeidsdelingen når det gjelder familiens økonomi, framstår dermed som svært kjønnsdelt hos en stor andel av de pakistanske og irakiske informantene. Samtidig gjelder ikke dette alle familiene i de pakistanske og irakiske familiene. Selv om fire av ti har en (kjønns) tradisjonell økonomisk arbeidsdeling, er det fortsatt seks av ti som har organisert seg på en annen måte - ved å dele likt, eller ved å dele (kjønns) utradisjonelt.

I likestillingstermer går likedeling ut på at kvinner tar en større rolle knyttet til familiens forsørgelse, og at menn tar en større rolle knyttet til hus- og omsorgsarbeid. Arbeidsdeling på tvers av det kjønnstradisjonelle - for eksempel at han gjør alt husarbeidet og hun har hovedansvaret for økonomien - hører fortsatt til unntakene, også i etnisk norske familier. Når det gjelder omsorg for barn blant innvandrede familier, er det likevel noen tendenser $\mathrm{i}$ «utradisjonell retning» som er verdt å notere. Foreldre deler vanligvis likt, både på å følge opp barnas skolegang og på den daglige omsorgen for barna. Blant iranske, irakiske, vietnamesiske og pakistanske foreldre har imidlertid far hovedansvaret hos en betydelig andel, spesielt i å følge opp barnas skolearbeid (Kavli og Nadim 2009). Dette kan skyldes systematiske forskjeller i mors og fars forutsetninger for å delta på norskspråklige arenaer som skole og helsestasjon. Innvandrede kvinner fra land utenfor Vesten har (i gjennomsnitt) lavere formell utdanning, mindre kontakt med norskspråklige arenaer gjennom lønnet arbeid, og dårligere norskferdigheter enn menn med samme landbakgrunn (Henriksen 2010).

Hovedmønstrene i hvordan menn og kvinner fordeler oppgaver seg imellom, er altså ganske like på tvers av landgruppene. De aller fleste menn er involvert i familiens økonomi og i vedlikeholdsarbeidet, mens de aller fleste kvinner er involvert i husarbeidet og i den daglige omsorgen for barna. Samtidig varierer omfanget av den kjønnede arbeidsdelingen. I grove trekk er arbeidsdelingen mellom menn og 
kvinner mindre kjønnstradisjonell blant nordmenn, iranere, og til en viss grad vietnamesere enn blant pakistanere og irakere. Årsaken til disse variasjonene er ikke bare knyttet til det «etniske», som i hvilket land familien har sin bakgrunn og hvilke familieverdier som dominerer der. Tidligere forskning om fordelingen av oppgaver i og rundt hjemmet har pekt på flere forhold av betydning.

I befolkningen sett under ett, ser mannens innsats hjemme ut til å øke dersom kvinnen har lønnet arbeid, og dersom hun arbeider mye. Mange barn, og særlig små barn, ser derimot ut til å påvirke par i mer tradisjonell retning. Og par der begge har høy utdanning, er, alt annet likt, mer likestilt i hjemmet enn par med lavere utdanning. Husarbeidet deles også jevnere i familier der mor har høy utdanning, og der mor har full jobb, enn i andre par. Både teoriene om «tilgjengelig tid» og «relative ressurser» finner altså støtte i norske studier (Bernhardt mfl. 2008, Kitterød 2004). Også i de innvandrede familiene øker sannsynligheten for at ansvaret for husarbeid, omsorgsarbeid og økonomi er jevnt fordelt, dersom kvinnen er i lønnet arbeid. Samtidig spiller informantenes landbakgrunn en rolle også etter at det er tatt hensyn til forhold som antall barn, yngste barns alder, parets utdanningsnivå og kvinnens yrkesaktivitet (Kavli og Nadim 2009). Dette kan, blant annet, være knyttet til ulike holdninger til hva slags ansvar som påligger henholdsvis kvinner og menn i en familie.

\section{Hvem bør gjøre hva? Holdninger til kvinners og menns oppgaver}

Informantene ble bedt om å ta stilling til tre påstander om hvordan ansvaret for oppgaver i og rundt familien bør fordeles. ${ }^{9}$ Påstanden om at kvinnen bør ha hovedansvaret for å holde hjemmet rent, deler utvalget i to grupper (figur 12.2). Blant norske og iranske informanter er det få som støtter påstanden, henholdsvis 8 og 24 prosent. Blant innvandrere fra Pakistan, Irak og Vietnam svarer derimot noe over halvparten at kvinnen bør ha hovedansvaret for å holde huset rent. Det er få kjønnsforskjeller, med unntak av blant vietnamesiske informanter, der kvinner i større grad enn menn er enig i at kvinner bør sørge for renholdet.

I motsetning til husarbeidet har forsørgerplikten tradisjonelt ligget på mannen. I Norge har kvinners økte deltakelse i arbeidslivet - og mannens økte deltakelse hjemme - trolig bidratt til å moderere oppfatningen om at mannen har et hoved-

9 Det presenteres et gjennomsnitt av menn og kvinners svar, men statistisk signifikante kjønnsforskjeller vil kommenteres underveis. 
ansvar for å forsørge familien. Bare 12 prosent i utvalget støtter påstanden om at mannen har hovedansvaret for å forsørge familien (figur 12.2), og det er bare ubetydelige forskjeller mellom menns og kvinners oppfatninger på dette området (ikke vist). Blant innvandrere i utvalget finner vi en langt større tilbøyelighet til å holde normativt fast ved det mannlige forsørgeransvaret. Blant personer fra Pakistan og Vietnam mener henholdsvis 70 og 73 prosent at forsørgeransvaret i hovedsak er mannens. Tilslutningen er noe lavere blant personer fra Irak (58 prosent) og vesentlig lavere blant personer som har innvandret fra Iran (34 prosent). Det er klart større holdningsforskjeller mellom landgruppene enn mellom kvinner og menn. Blant iranere er det likevel vesentlig færre kvinner enn menn som mener at mannen har hovedansvaret for å forsørge familien.

Figur 12.2 Andel personer som er helt eller delvis enig i påstanden. I prosent, etter landgruppe. Gjennomsnitt for menn og kvinner. $\mathrm{N}=1268$

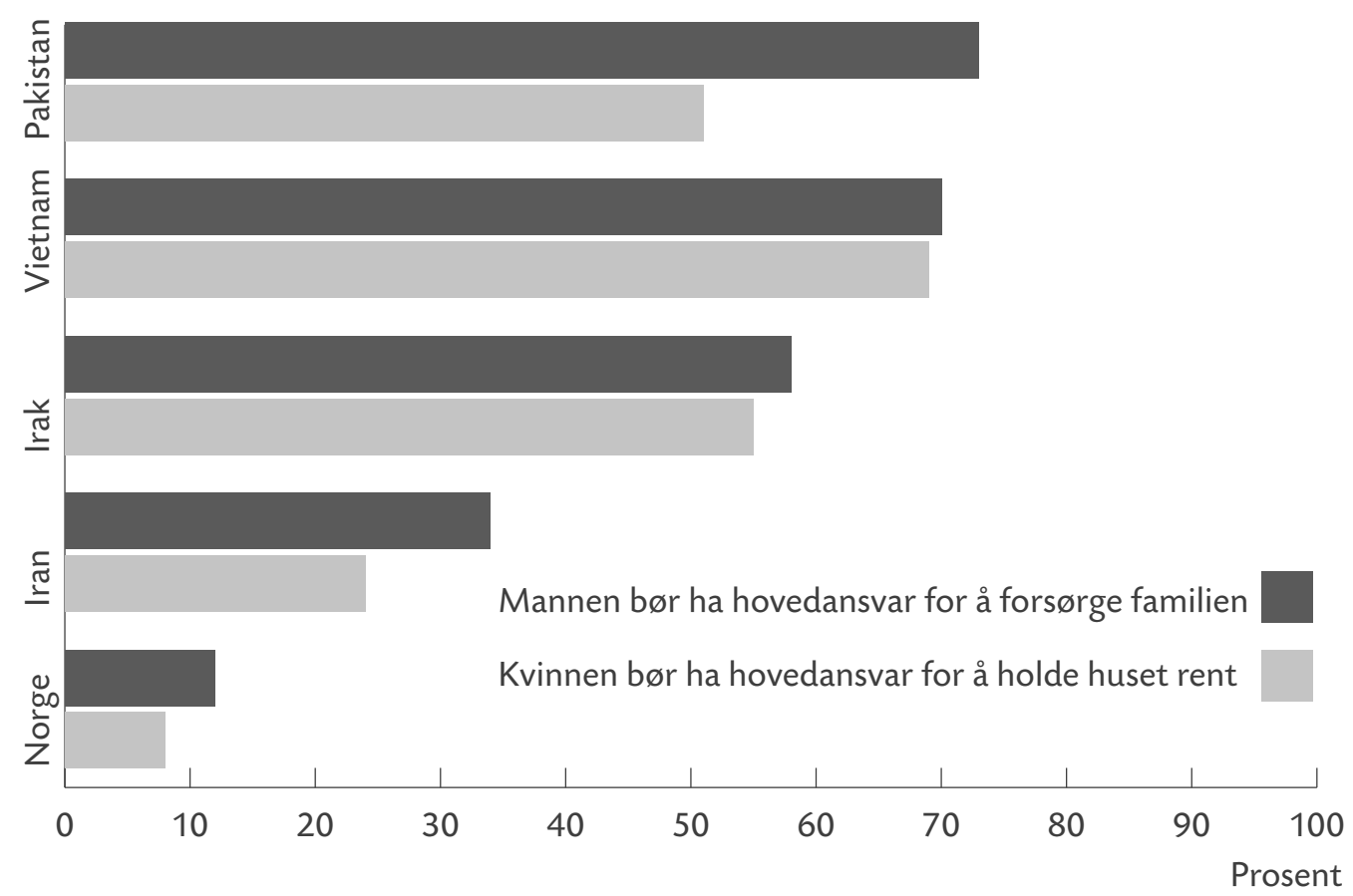

Et betydelig flertall i alle landgrupper mener menn og kvinner er like godt skikket til å ta vare på barn (figur 12.3). Samtidig dreier dette spørsmålet seg kun om generell skikkethet, og ikke hvilken, eller hvor stor del av omsorgsarbeidet man mener menn og kvinner bør ha ansvar for. Selv om de aller fleste mener at kvinner kan være i lønnet arbeid også etter at de har fått barn, er barnets alder av stor betydning for oppfatningene om når mor kan arbeide utenfor hjemmet, og hvor mye. Norske kvinner og menn er langt mer positive til at kvinner kan ha lønnet arbeid også mens familien har små barn, enn både personer fra Pakistan, Irak, Iran og Vietnam (figur 12.3). Andelen som mener at mødre kan arbeide utenfor hjem- 
met, øker med yngste barns alder, men i ulik grad for ulike grupper (Kavli og Nadim 2009). Størst skepsis til at kvinner arbeider i småbarnsfasen, finner vi i vårt utvalg blant personer fra Pakistan, der bare 30 prosent mener mor kan arbeide utenfor hjemmet mens hun har barn mellom 0 og 3 år. I de øvrige landgruppene mener mellom 69 og 89 prosent at mor kan arbeide utenfor hjemmet også med små barn, men et klart flertall svarer at deltid da er det beste alternativet.

Figur 12.3 Andel personer som er helt eller delvis enig i påstanden (1) «Kvinner og menn er like godt skikket til å ta vare på barn», og som mener at «Kvinner kan arbeide (2) heltid eller (3) deltid når familien har barn under 3 år». I prosent, etter landbakgrunn. Gjennomsnitt for menn og kvinner. $\mathrm{N}=1110$

Kvinner og menn er like godt skikket til å ta vare på barn Kvinner kan arbeide heltid når familien har barn under 3 år Kvinner kan arbeide deltid når familien har barn under 3 år

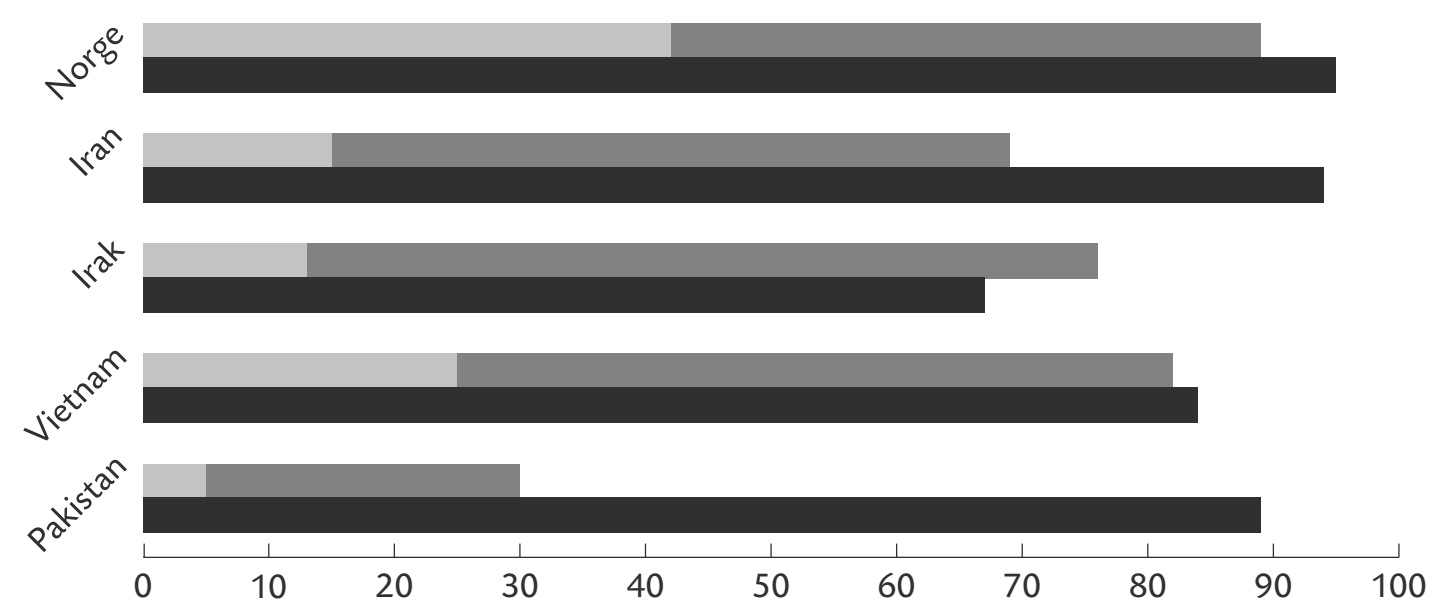

Holdninger til kjønnslikestilling varierer gjerne etter kjønn, alder og utdanning. I majoritetsbefolkningen er kvinner sett under ett mer positive til kjønnslikestilling enn menn, yngre i større grad enn eldre og høyt utdannede mer enn lavt utdannede (Knutsen og Wærness 2001). De samme tendensene finnes blant innvandrere. Holdningene er gjennomgående mer positive til en likedeling hos høyt utdannede enn blant lavt utdannede, og i en viss grad også mer blant kvinner enn blant menn. Variasjonene mellom landgruppene i holdninger til renhold, forsørgelse og generell skikkethet i å ta vare på barn kommer imidlertid ikke av ulik sammensetning av gruppene med tanke på kjønn, alder ${ }^{10}$ eller utdanning. Når det gjelder sannsynlig-

10 Aldersgruppen i dette materialet er så sammenpresset (20-55 år) at en analyse av alder ikke gir noe fullstendig bilde av eventuelle aldersforskjeller. Poenget her er primært å undersøke om landbakgrunn er en signifikant variabel også etter kontroll for de forholdene som vanligvis bidrar til å forklare variasjoner i holdninger til kjønnslikestilling. 
heten for å svare at mødre ikke bør ha lønnet arbeid mens familien har barn $\mathrm{i}$ alderen 0-3 år, slår bare landbakgrunn ut, ikke kjønn eller utdanning (regresjonsanalyser ikke vist).

\section{Som sagt, så gjort? Konsistens eller dissonans mellom holdninger og praksis}

Ulike konfigurasjoner av holdninger og praksis vil gi ulike typer konsistens og dissonans. Disse er illustrert i analysemodellen nedenfor. I rute A, som jeg har kalt «Likestillingsdissonans», finner vi personer med likestilte holdninger, men kjønnsdelt praksis. Blant informanter med «Tradisjonell dissonans» (C) er situasjonen motsatt - holdningen støtter en kjønnsdeling, mens praksis er likestilt. Og på samme måte finnes også likestillingskonsistens (B) eller tradisjonell konsistens (D), der holdning og praksis sammenfaller.

\begin{tabular}{|c|c|c|c|}
\hline A. & $\begin{array}{l}\text { LIKESTILLINGSDISSONANS } \\
\text { Likestilt holdning og } \\
\text { tradisjonell praksis }\end{array}$ & B. & $\begin{array}{l}\text { LIKESTILLINGSKONSISTENS } \\
\text { Likestilt holdning og } \\
\text { likedelt praksis }\end{array}$ \\
\hline C. & $\begin{array}{l}\text { TRADISJONELL DISSONANS } \\
\text { Tradisjonell holdning og } \\
\text { likedelt praksis }\end{array}$ & D. & $\begin{array}{l}\text { TRADISJONELL KONSISTENS } \\
\text { Tradisjonell holdning og } \\
\text { tradisjonell praksis }\end{array}$ \\
\hline
\end{tabular}

Analysemodell: Holdninger og praksis knyttet til kjønnslikestilling

Figurene 12.4 og 12.5 plasserer hver landgruppe empirisk inn i analysemodellen med hensyn til fordelingen av husarbeid og familiens forsørgelse. ${ }^{11}$ Landgruppenes plassering i figuren er en funksjon av om flertallet har likestillingsorienterte eller tradisjonelle holdninger, og om de har en likestilt eller tradisjonell praksis. ${ }^{12}$ Norske og iranske informanter ligger klart plassert i retning «likestillingskonsistens» $(\mathrm{B})$, både når det gjelder husarbeid og lønnsarbeid. Her er det med andre ord mest vanlig å ha både likestillingsorienterte holdninger og praksiser. Blant

11 Spørsmålene om holdning og praksis knyttet til omsorgsarbeid er såpass ulike at de ikke egner seg for den samme typen dissonans/konsistens-analyse som det er lagt opp til her.

12 Plasseringen på aksen dissonans/konsistens er en funksjon av (andel med likestilte holdninger) minus (andel med tradisjonelle holdninger), og plassering på aksen kjønnslikestilt - kjønnsdelt er en funksjon av (andel med likestilt praksis) minus (andel med tradisjonell praksis). 
vietnamesiske informanter dreier tyngdepunktet mot en «tradisjonell dissonans» (C), der holdningen tilsier at en kjønnsdelt arbeidsdeling er å foretrekke, men der praksis er mer kjønnslikestilt. Irakiske informanter har et lite tyngdepunkt i kategorien «tradisjonell konsistens» (D). Plasseringen er imidlertid svært nær sentrum i figuren både når det gjelder husarbeid og forsørgerarbeid. Det betyr at de irakiske informantene fordeler seg relativt jevnt mellom de fire kategoriene. Blant pakistanerne har holdninger og praksis knyttet til husarbeid et (lite) tyngdepunkt i kategorien «tradisjonell konsistens» (D), mens spørsmålene om forsørgelse skyver flertallet over i kategorien «tradisjonell dissonans» $(\mathrm{C})$. Et flertall blant pakistanere (og vietnamesere) i utvalget støtter dermed påstanden om at det er mannens hovedansvar å forsørge familien, samtidig som forsørgeransvaret i deres familie er likedelt mellom ham og henne.

Figur 12.4 Bivariate sammenhenger mellom holdninger til hvem som bør ha hovedansvaret for å HOLDE HUSET RENT, og hvem som i praksis gjør renholdsarbeidet, etter landgruppe. Gjennomsnitt av menn og kvinners svar. $\mathrm{N}=1110$

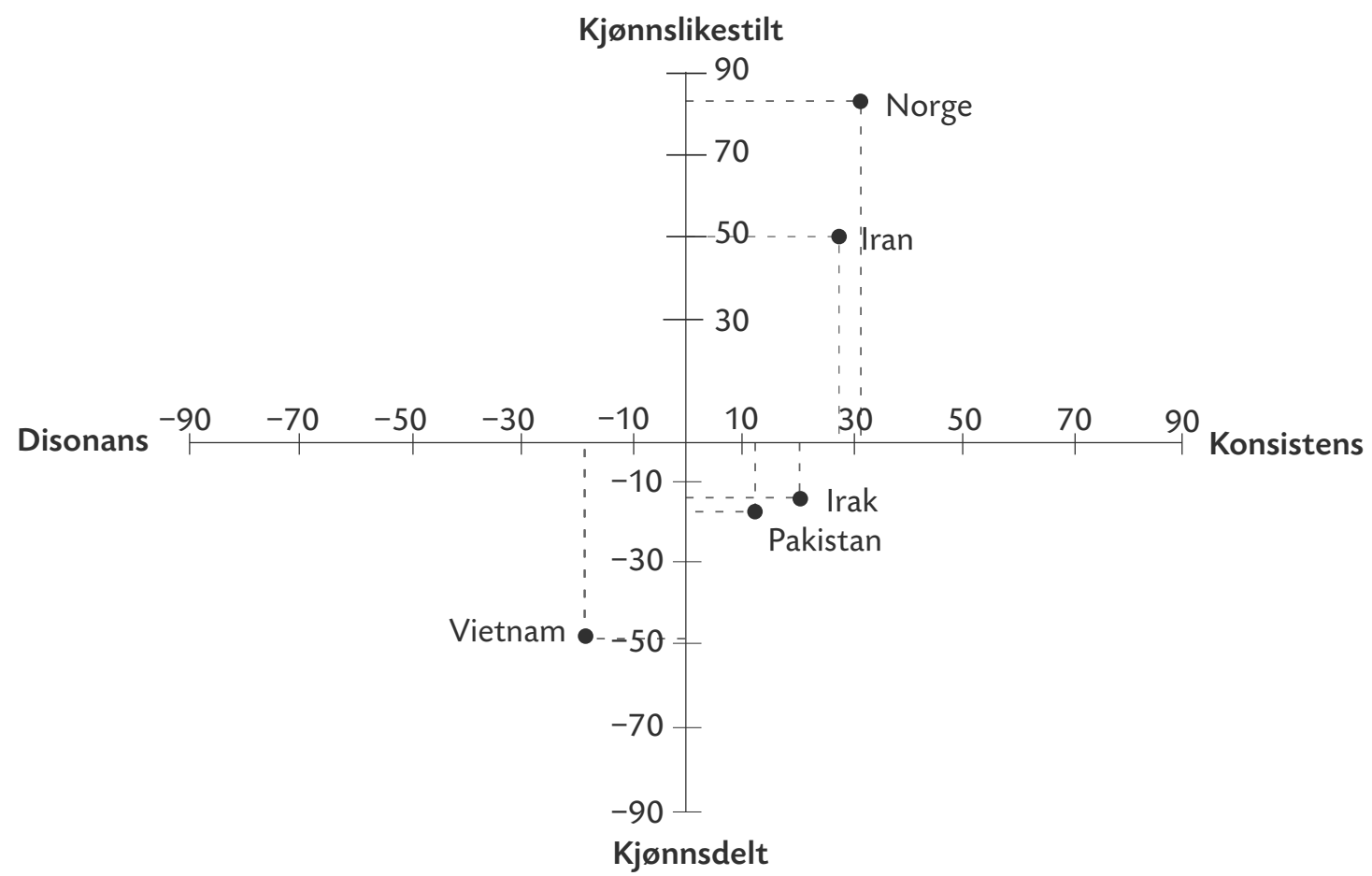


Figur 12.5 Bivariate sammenhenger mellom holdninger til hvem som bør ha hovedansvaret for å FORS $\varnothing$ RGE FAMILIEN, og hvem som i praksis forsørger familien, etter landgruppe. Gjennomsnitt av menn og kvinners svar. $\mathrm{N}=1110$

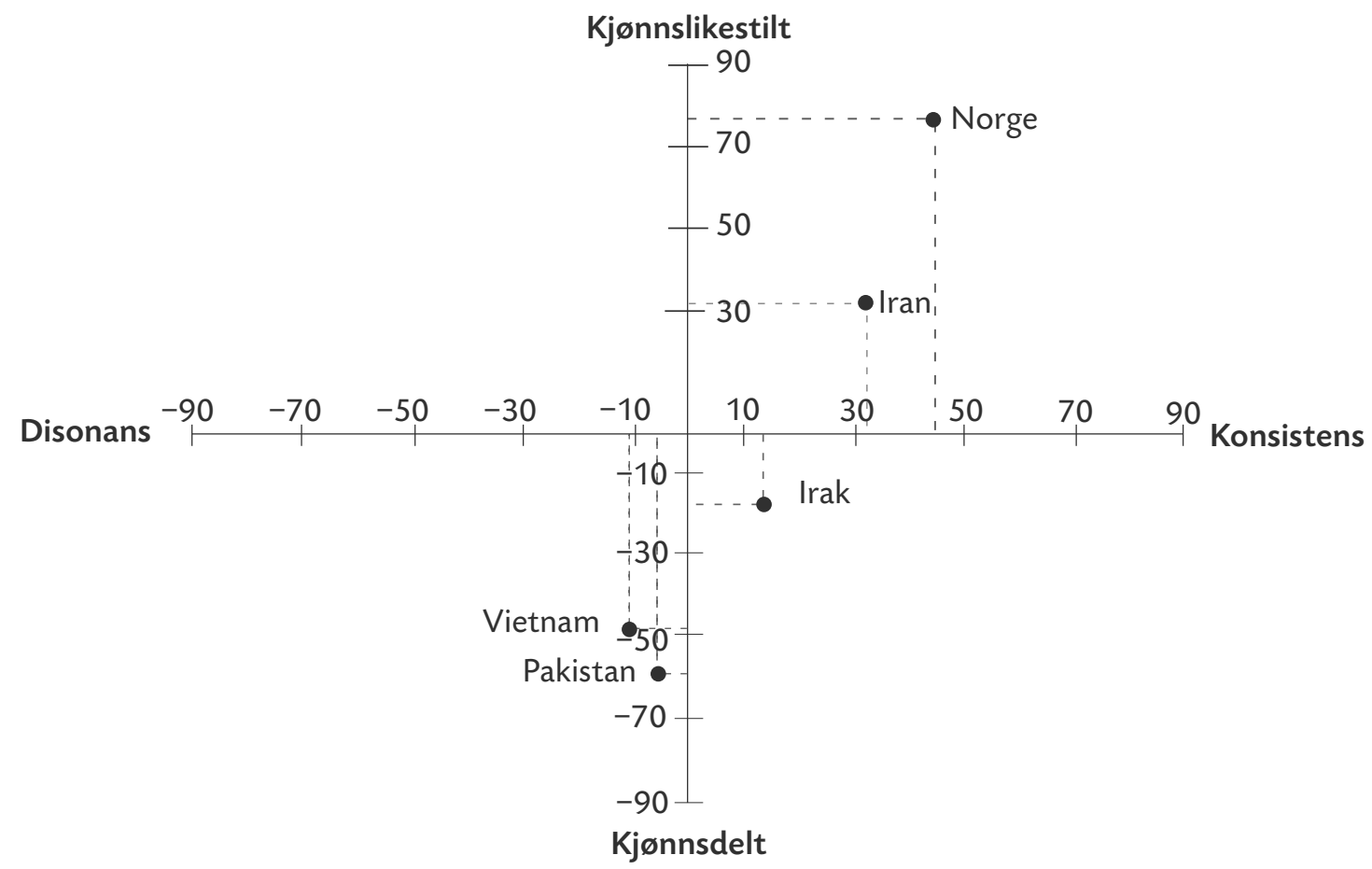

Figurene 12.4 og 12.5 illustrerer hvor tyngdepunktet av informantene i hver landgruppe befinner seg, og gir dermed et oversiktsbilde. Den tydeligste tendensen er dominansen av likestilt konsistens blant norske og iranske informanter. I de andre tre landgruppene er overvekten i en kategori mindre framtredende, og det er derfor nyttig å studere fordelingene litt nærmere.

Figurene 12.6 og 12.7 viser andelen informanter med konsistente eller dissonante svar knyttet til husarbeid og forsørgelse i hver av de fem landgruppene. Her ser vi for det første at dissonans er klart mer utbredt i de fire innvandrede gruppene enn i majoritetsbefolkningen. ${ }^{13}$ Forskjellene er spesielt tydelige når det gjelder familiens forsørgelse. Her rapporterer færre enn 3 av 10 norske informanter om dissonans, mot flere enn 5 av 10 vietnamesere og pakistanere. For det andre går avviket mellom holdning og praksis i ulik retning i de ulike landgruppene. Blant norske og iranske informanter finner vi klart mest likestilt dissonans - altså at holdningene er mer likestilt enn praksis. Blant innvandrere fra Vietnam, Irak og Pakistan er det motsatt - praksis er mer likestilt enn holdningene.

13 Innvandrere fra Irak, Vietnam og Pakistan har signifikant høyere dissonans mht. forsørgerarbeid enn personer fra Norge. Innvandrere fra Vietnam og Pakistan har signifikant høyere dissonans mht. husarbeid enn personer fra Norge. 
Figur 12.6 Konsistens eller dissonans mellom holdninger og praksis knyttet til HUSARBEID*. Etter landbakgrunn. I prosent. $\mathrm{N}=1200$

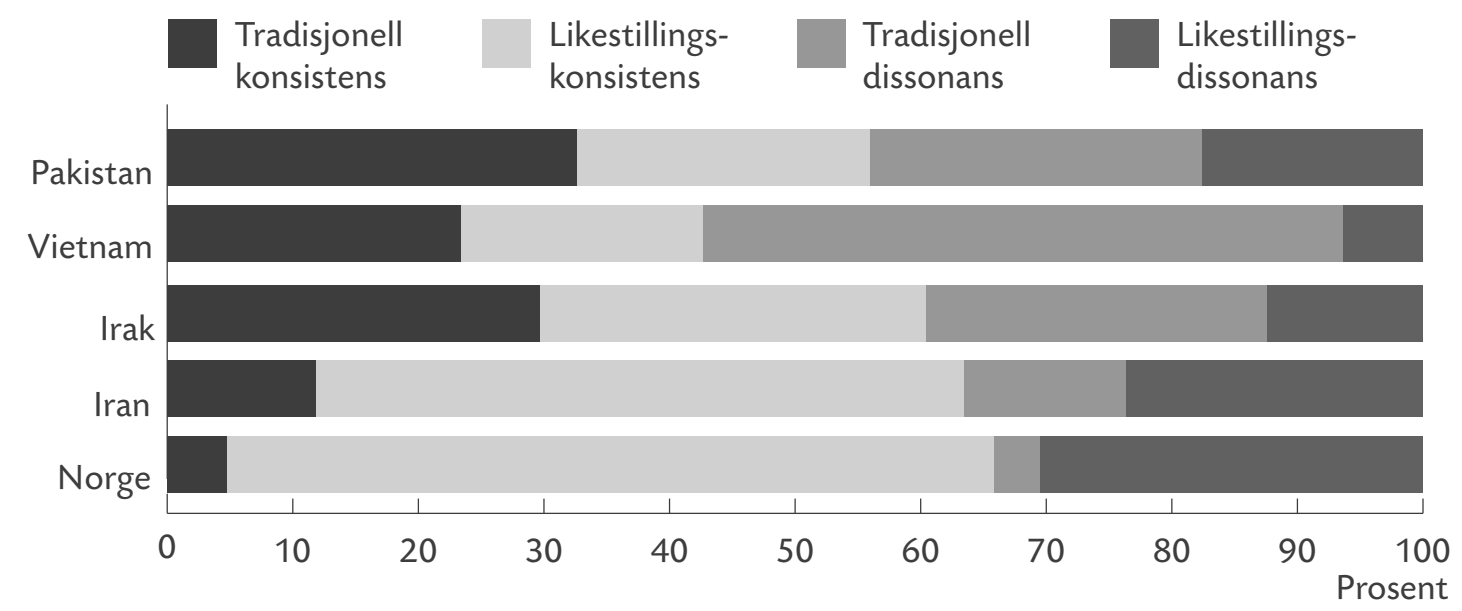

* Inkluderer spørsmålene «Hvor enig eller uenig er du i at ... Det er kvinnens hovedansvar å holde hjemmet rent» og «Hvordan fordeler du og din ektefelle/partner/samboer vanligvis følgende arbeidsoppgave ... Husarbeid, som å vaske klær, lage mat, gjøre rent og handle mat».

Figur 12.7 Konsistens eller dissonans mellom holdninger og praksis knyttet til FAMILIENS FORS $\varnothing R G E L S{ }^{*}$. Etter landbakgrunn. I prosent. $N=1200$

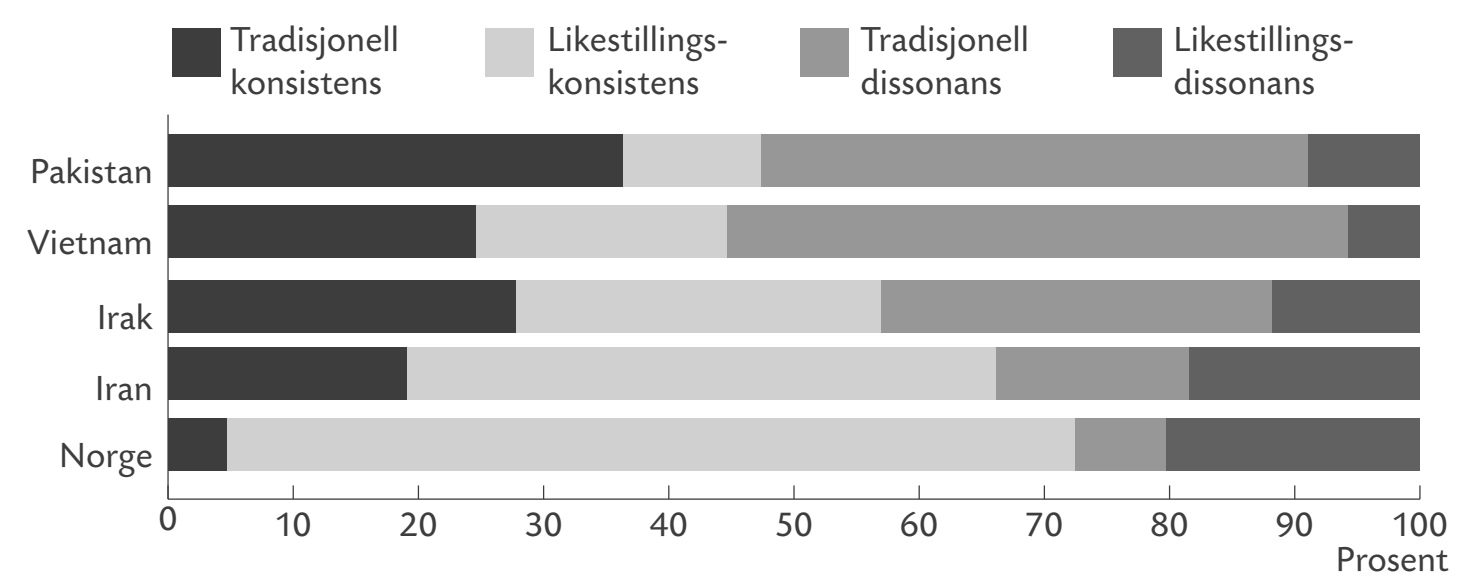

* Inkluderer spørsmålene «Hvor enig eller uenig er du i at ... Det er mannens hovedansvar å forsørge familien» og «Vil du si at du selv har størst ansvar for familiens økonomi, at din ektefelle/partner/samboer har det, eller at dere deler ansvaret likt?».

Blant innvandrere i foreliggende undersøkelse er kjønnsdimensjonen langt mindre slående enn variasjonene mellom landgrupper (ikke vist). Pakistanske kvinner rapporterer likevel (tradisjonell) dissonans i signifikant større grad enn pakistanske menn, både når det gjelder husarbeid og forsørgelse. Også blant andre landgrupper finnes tendenser til kjønnsforskjeller både i omfang og type dissonans, men de er i hovedsak ikke statistisk signifikante, og jeg har derfor ikke gått videre med disse analysene her. 


\section{Arbeidsdeling i innvandrede familier - strukturer og holdninger}

Norsk familie-, integrerings- og velferdspolitikk er ikke nøytral. Det er heller ikke intensjonen. Politikk er motivert ut fra en ambisjon om å påvirke samfunnet $\mathrm{i}$ «ønsket» retning. Når det gjelder flyktninger og innvandrere, var oppfatningen lenge at offentlig politikk ikke skulle gå på tvers av de verdier og levemåter innvandrere hadde da de kom. Brochmann (2002: 36-37) beskriver hvordan myndighetene skulle legge til rette for reelle valg og beskytte innvandrere mot assimileringskrefter i samfunnet. Et illustrerende eksempel finnes i stortingsmeldingen «Om innvandrere i Norge» (nr. 74, 1979-80), der behovet for å opplyse innvandrede foreldre om assimileringsfaren ved å sende barna i norske barnehager presiseres. Avstanden er betydelig til dagens integreringspolitikk, som legger vekt på at barn bør i barnehage og kvinner i kvalifisering med tanke på lønnet arbeid. I takt med $ø$ kt innvandring og framveksten av arbeidslinja har både diskursen og virkemidlene endret seg (Djuve og Kavli 2007). Innvandrede kvinners posisjon har gått fra å være en sak for familien til en sak for samfunnet.

Blant innvandrede familier fra Iran, Irak, Vietnam og Pakistan lever en betydelig andel likestilt i den forstand at de deler hus-, lønns- og omsorgsarbeid mellom seg. Dette er en viktig side ved innvandrede familiers liv i Norge som ofte overses, både i faglig og offentlig debatt. Samtidig er arbeidsdelingen mellom menn og kvinner mindre kjønnstradisjonell blant norske, iranske og til en viss grad vietnamesiske informanter enn blant irakiske og pakistanske. Dette gjelder spesielt familiens forsørgelse. Variasjonene mellom landgruppene lar seg et stykke på vei forklare av forhold som utdanning, kvinners yrkesaktivitet og familiefase, men ikke helt. Praksis preges trolig også av ulike holdninger til menn og kvinners rolle i familien.

Forholdet mellom holdninger til arbeidsdeling i familien - og faktisk arbeidsdeling kan leses som et uttrykk for hvor lett eller vanskelig det er for ulike grupper å realisere sine ideer om et godt familieliv. Dissonans forstås da som et uttrykk for at holdninger og praksis er i utakt. Slik dissonans er mer utbredt blant informanter fra Irak, Vietnam og Pakistan enn blant norske og iranske informanter. Dissonansen er også av ulik art. Blant informanter med bakgrunn fra Irak, Vietnam og Pakistan er praksis i hovedsak mer likestilt enn holdningene (tradisjonell dissonans). Dette kommer spesielt fram i synet på familiens forsørgelse, men også når det gjelder husarbeid. Blant iranske og norske informanter er dissonans er mindre utbredt, og dreier seg i hovedsak om at praksis er mindre likestilt enn holdningene skulle tilsi (likestillingsdissonans). 
En sentral ambisjon for velferdsstaten er å moderere effekten av arbeidsmarkedet og arbeidsmarkedets strukturer på individers levekår. Ulike typer av velferdsstater gjør dette på ulike måter. De skandinaviske velferdsstatene har dessuten prioritert å legge til rette for større grad av likedeling mellom menn og kvinner både $\mathrm{i}$ arbeidsliv og hjemme (se for eksempel Esping Anderssen 2009 og Korpi 2010). «Tradisjonell dissonans» kan leses som et uttrykk for at velferdsstaten skyver familier med kjønnstradisjonelle holdninger i retning av en mer kjønnslikestilt praksis, både gjennom den generelle familiepolitikken og mer spesifikt gjennom ulike typer av integreringspolitiske tiltak. En alternativ (eller supplerende) forklaring kan være at markedet faktisk virker modererende på betydningen av holdninger. Irakere, vietnamesere og pakistanere er, sett under ett, mer tradisjonelt orientert enn nordmenn og iranere, men praksis er likere enn holdningene skulle tilsi. Det kan bety at behovet for å bidra til en trang familieøkonomi presser kvinner i de førstnevnte gruppene ut i arbeid. Her ligger et av velferdsstatens dilemmaer i likestillingsarbeidet - ved å kompensere for manglende arbeidsinntekt kan arbeidsinsentivene svekkes.

«Likestilt dissonans» tyder på at det også kan være vanskelig å kombinere likestilte holdninger med en (like) likestilt praksis. Familiene forholder seg til strukturer som ligger både i arbeidslivets organisering og velferdsstatens prioriteringer. Kari Skrede (2004: 193) har spurt om dagens norske familiepolitikk bidrar til å sementere en «likestilling light». Hun viser hvordan familiepolitikken både legger til rette for et likestilt foreldreskap og har ordninger som trekker i motsatt retning. Kan hende bidrar dette doble sporet til å forsterke forekomsten av den likestilte dissonansen vi har sett, først og fremst blant norske og iranske informanter, ved at en kjønnslikestilt praksis i noen situasjoner blir økonomisk vanskeligere å velge.

Velferdsstatens utforming og prioriteringer kan også bidra til, og befeste, konsistens. Det er liten tvil om at norsk familie- og likestillingspolitikk på mange måter har gjort det lettere å leve likestilt. Modellen, og likestillingseffekten av den, bygger imidlertid på en forutsetning om at både kvinner og menn deltar i arbeidslivet. I de innvandrede familiene vi har rettet søkelyset mot, står en betydelig andel av kvinnene utenfor arbeidslivet i lengre perioder. Konsekvensen er at det er i egenskap av å være mor at de får tilgang til offentlige velferdsytelser og ikke, som flertallet av etnisk norske kvinner, i egenskap av å være yrkesaktive (Kavli 2004: 313). Velferdsstatens økonomiske ansvar for familier som ikke greier å skaffe nok inntekter gjennom lønnet arbeid, kan dermed bidra til å opprettholde en «tradisjonell konsistens» når det gjelder arbeidsdelingen i familien, nettopp ved å (delvis) skjerme dem fra de økonomiske konsekvensene av å ikke delta i arbeidslivet. Ordningene treffer dessuten ulikt avhengig av økonomisk posisjon - de som har 
minst å hente ut av arbeidsmarkedet får i størst grad svekket sine arbeidsinsentiver. Samtidig har det politiske klimaet de senere årene endret seg, spesielt i integreringspolitikken. De rene overføringene har blitt færre og aktivitetsbaserte ytelser mer vanlig. Kanskje vil velferdsstaten dermed spille en større rolle som endringsagent også i kjønnstradisjonelt orienterte familier i tiden framover.

Holdninger til kvinners yrkesdeltakelse har endret seg kraftig i den norske befolkningen siden 1970-tallet. I 1977 mente 7 av 10 norske kvinner at småbarnsmødre ikke burde være yrkesaktive. Tretti år senere var det færre enn 1 av 10 som mente at barna ville lide dersom mor var yrkesaktiv (Lappegård og Noack 2009). Holdninger er ikke statiske, selv om de endres langsomt. Familie-, velferds- og integreringspolitikken bør derfor forstås og utformes i et generasjonsperspektiv. Analysene i dette kapitlet bygger på et tverrsnitt av situasjonen blant nordmenn og innvandrere «her og nå», noe som gjør det vanskelig å få øye på dynamikken. Viktige tema for videre studier bør derfor være knyttet til nettopp endring. Hvor mye endring, i holdninger og i praksis, har allerede funnet sted i de ulike delene av den innvandrede befolkningen i Norge? Hvor mye endring kan vi forvente, og, i forlengelsen av det, er dissonansen mellom holdninger og praksis på likestillingsområdet et midlertidig eller vedvarende trekk ved de familiene det gjelder? Et viktig tema er også forholdet mellom holdninger og praksis blant etterkommere av innvandrere i Norge. Hvis foreldrene har kjønnstradisjonelle holdninger, men likestilt praksis, hvordan vil det prege etterkommere?

\section{Litteratur}

Bernhard, E,T. Noack og T. Lyngstad (2008): «Shared housework in Norway and Sweden: advancing the gender revolution». Journal of European Social Policy, vol. 18 (3): 275-288. SAGE.

Bolzendahl, C. og D. Myers (2004): «Feminist Attitudes and Support for Gender Equality: Opinion Change in Women and Men, 1974-1998». Social Forces 83: 759-790.

Brochmann, G., T. Borchrevink og J. Rogstad (2002): Sand i maskineriet. Oslo: Gyldendal Akademisk.

Bühlmann, F., G. Elcheroth og M. Tettamanti (2010): «The division of labour among european couples: The effects of life course and welfare policy on value-practice configurations. European Sociological Review, vol. 26, nr. 1, pp. 49-66. Oxford University Press.

Coltrane, S. (2000): Research on Household Labor: Modeling and Measuring the Social Embeddedness of Routine Family Work. Journal of Marriage and the Family 62: 1208-1233.

Djuve, A.B., H.C. Kavli og A. Hagelund (2012): «Innvandrede kvinner i kvalifisering», under utgivelse i S. Stjernø og E. Øverbye (red.): /tittel/ Oslo: Universitetsforlaget.

Djuve, A.B., E. Gulløy, H.C. Kavli og F. Berglund (2009): Datafangst når minoritetsbefolkningen er målgruppe. Oslo: Fafo-rapport 2009: 24. 
Djuve, A.B. og H.C. Kavli (2007): «Integreringspolitikk i endring», kap. 8 i Dølvik, J.E., T. Fløtten, G. Hernes og J.M. Hippe (red.): Hamskiftet. Den norske modellen i endring. Oslo: Gyldendal Akademisk.

Elster, J. (1983): Sour grapes. Studies in the Subversion of Rationality. Cambridge University Press.

Esping-Andersen, G. (2009): The incomplete revolution. Adapting to women's new roles. Cambridge: Polity Press.

Geist, C. (2005): The welfare state and the home: regime differences in the Domestic Division of labour. European Sociological Rewiev, 21, 23-41. Oxford University Press.

Hochschild, A.R. (1989/1997): The Second Shift: Working Parents and the Revolution at Home (med Anne Machung). New York: Viking Penguin.

Hellevik, O. (2002):«Forskning på verdier: Eksempler fra kvantitativ samfunnsforskning». I: K.I. Johannessen og U. Schmidt (red.): Verdier-flerfaglige perspektiver. Trondheim: Tapir Akademisk Forlag.

Hellevik, T og O. Hellevik (2012): «Holdninger til likestilling». I: Hansen, T. og Slagsvold, B. (red.): Likestilling hjemme. Under utgivelse/2012. Oslo: NOVA.

Henriksen, K. (2010): Levekår og kjønnsforskjeller blant innvandrere fra 10 land. Rapporter 6/2010: Oslo: Statistisk sentralbyrå.

Hurlen-Foss, A. (2006): Fruktbarhet blant innvandrerkvinner 10.10.2006. Oslo: Statistisk sentralbyrå.

Huntington, S. (1996): The Clash of Civilizations and the Remaking of World Order. New York: Simon \& Schuster.

Haavind, H. (1984): «Love and Power in marriage». I: Holter, H. (red.): Patriarchy in a Welfare Society. Oslo: Universitetsforlaget.

Ingelhart, R. (1977): The Silent Revolution - Changing Values and Political Styles among Western Publics. Princeton: Princeton University.

Ingelhart, R. og P. Norris (2003): Rising Tide. Gender equality and cultural change around the world. Cambridge: Cambridge University Press.

Kavli, H.C. (2004): «Familiepolitiske dilemmaer i det fleretniske samfunnet». I: Ellingsæther, A.L. og A. Leira (red.): Velferdsstaten og familien. Utfordringer og dilemmaer. Oslo: Gyldendal Akademisk.

Kavli, H.C og M. Nadim (2009): Familiepraksis og likestilling i innvandrede familier. Oslo: Fafo-rapport 2009: 39.

Kavli, H., A. Hagelund og M. Bråthen (2007): Med rett til å loere og plikt til å delta. En evaluering av introduksjonsprogrammet for nyankomne flyktninger og innvandrere. Oslo: Fafo-rapport 2007: 34 .

Kitterød, R.H. (2004): Hvem gjør mest hjemme? Hva sier mor og hva sier far? Samfunnsspeilet 18 (6): 39-48. Oslo: Statistisk sentralbyrå.

Kjelstad, R. og T. Lappegård (2012): «How do gender values and household practices cohere? Value-practice configurations in a gender egalitarian context. Discussion Papers No. 683. Oslo: Statistics Norway.

Knudsen, K. og K. Wærness (2001): «National Context, Individual Characteristics and Attitudes on Mothers' Employment: A Comparative Analysis of Great Britain, Sweden and Norway». Acta Sociologica, 2001. 
... (2008): National Context and spouses housework in 34 countries. European Sociological Review, vol. 24, nr. 1, s. 97-113. Oxford University Press.

Korpi, W., T. Ferrarini og S. Englund (2010): Women's Opportunities Under Different Constellations of Family Policies in Western Countries: A Comparative Analysis. Working paper no. 556, Luxembourg Income Study.

Lappegård, T. og T. Noack (2009): «Barn, familie og jobb - holdninger og praksis gjennom 30 år. Familie og jobb i ulike kvinnegenerasjoner». Samfunnsspeilet nr. 1, 2009. Oslo: Statistisk sentralbyrå.

Modood, T. mfl. (1997): Ethnic Minorities in Britain. Diversity and Disadvantage. Policy Studies Institute: University of Westminster.

Pinto, K.M. og S. Coltrane (2009): Divisions of Labor in Mexican and Anglo Families: Structure and Culture. Sex Roles 60: 482-495.

Skrede, K. (2004): «Familiepolitikkens grense - ved «likestilling light»?», s. 160-200 i Ellingsæter, A.L. og A. Leira (red.): Velferdsstaten og familien. Utfordringer og dilemmaer. Oslo: Gyldendal Akademisk.

Usdansky, M.L. (2011): «The Gender-Equality Paradox: Class and Incongruity Between WorkFamily Attitudes and Behaviours». I: Journal of Family Theory \& Review 3: 163-178.

\section{Andre kilder}

NOU 2001: 20: Lov om introduksjonsordning for nyankomne innvandrere (introduksjonsloven).

Kommunal- og regionaldepartementet.

P4, 15. mai 2009: «Innvandrerfedre tar oppvasken», http://www.p4.no/story.aspx?id=309 627

Statistisk sentralbyrå, 11. april 2012. Befolkningsstatistikk. Fødte 2011.

TV 2, 11. mai 2009: «Raja skeptisk til Huitfeldts krav til innvandrermenn».

VG, 11. mai 2009: «Statsråden ber innvandrerfedre skifte bleier». 
Artikkel 2 Integrert eller marginalisert?

Innvandrede kvinner i norsk arbeidsliv 



\title{
Integrert eller marginalisert? Inn- vandrede kvinner i norsk arbeidsliv
}

\author{
HANNE CECILIE KAVLI \\ hanne.kavli@fafo.no \\ HEIDI NICOLAISEN \\ heidi.nicolaisen@fafo.no
}

Det er godt dokumentert at innvandrede kvinner har lavere sysselsetting enn norske kvinner uten innvandringsbakgrunn. Men hva preger deltakelsen i arbeidslivet blant de som har fătt en fot innenfor? I denne artikkelen studeres mobilitet $\mathrm{i}$ arbeidstid og arbeidstilknytning gjennom å ta i bruk registerdata der kvinner som var sysselsatt i 2009 følges fram til og med 2012. Norske kvinner sammenliknes med kvinner som har innvandret fra Irak, Iran, Pakistan, Somalia og Vietnam. Vi finner at deltidsarbeid er langt mer stabilt hos kvinner uten innvandrerbakgrunn. Kvinner fra Irak, Iran, Somalia og Vietnam har større tilbøyelighet til å øke arbeidstiden enn norske kvinner, noe som kan tyde på høyere grad av ufrivillig deltid. Samtidig er bevegelsen ut av lønnet arbeid langt mer omfattende blant innvandrede enn blant norske kvinner. Dette gjelder også etter kontroll for variasjoner i utdanning, familiesituasjon, type arbeid og arbeidstid. Analysene tyder på at innvandrede kvinner sett under ett har en mer marginalisert posisjon i norsk arbeidsliv enn kvinner uten innvandringsbakgrunn, men viser også at det er store variasjoner på dette området mellom kvinner fra ulike landgrupper.

Nøkkelord: deltidsarbeid I innvandrede kvinner I økonomisk integrering I marginalisering | mobilitet
INTEGRATED OR MARGINALIZED? IMMIGRANT WOMEN AT WORK IN NORWAY

It is well documented that immigrant women have lower employment than Norwegian women without an immigrant background. But what characterizes the labour force participation among those who have found work? This article studies mobility in working hours and work affiliation through adopting registry data where women who were employed in 2009 are followed until 2012. Norwegian women are compared with women who have immigrated from Iraq, Iran, Pakistan, Somalia and Vietnam. We find that part-time work is a more stable working relation among Norwegian than among immigrant women. Women from Iraq, Iran, Somalia and Vietnam are more likely to increase working hours than Norwegian women, which may indicate a higher degree of involuntary part-time. However, the movement out of paid work far is more extensive among immigrants than among Norwegian women. This also applies after control for variations in education, family situation, type of work and working hours. The analyses suggest that immigrant women as a whole have a more marginalized position in Norwegian working life than women without an immigrant background, but also show that there is considerable variation in this area between women from different groups of countries.

Keywords: part-time work I immigrant women I economic integration I marginalization | mobility 
$\varnothing$ KT INNVANDRING HAR FØRT økonomisk integrering stadig høyere på dagsordenen. Mens et stigende antall studier har tatt for seg innvandrede menns deltakelse i arbeidsmarkedet, har kvinners yrkesdeltakelse fått mindre oppmerksomhet. I den grad kvinner studeres, handler det gjerne om hvorfor så mange står utenfor arbeidslivet. Hva som preger deltakelsen i arbeidslivet for de som har fătt en fot innenfor, vet vi mindre om (Rubin 2008). Like fullt - i 2015 var over 166000 innvandrede kvinner i lønnet arbeid i Norge, hvorav flere enn 60000 hadde bakgrunn fra Asia eller Afrika. ${ }^{1}$ Vi har begrenset kunnskap om hva som preger deres yrkesdeltakelse, hvordan den utvikler seg over tid, og hvilke implikasjoner dette har for hvordan vi kan forstå innvandrede kvinners integrering i norsk arbeidsliv. I denne artikkelen retter vi søkelyset mot innvandrede kvinner fra Irak, Iran, Pakistan, Somalia og Vietnam som har det til felles at de alle har hatt lønnet arbeid i Norge. Analysene bygger på detaljerte, longitudinelle registerdata der kvinnenes tilknytning til arbeidslivet følges fra 2009 og tre år fram i tid.

Vi bruker arbeidstid som et utgangspunkt for å analysere innvandrede kvinners integrering $\mathrm{i}$ arbeidsmarkedet. Veksten i norske kvinners $^{2}$ yrkesdeltakelse på 1970-tallet skjedde i stor grad i form av deltidsarbeid, og forskning viser at deltidsarbeid tidlig ble «normalisert» i den forstand at de ansatte hadde en stabil tilknytning til arbeidslivet og tidlig fikk arbeidsvilkår og rettigheter som langt på vei tilsvarte fulltidsansattes (Ellingsæter 1989). Deltid kan likevel ikke forstås som én bestemt type arbeidsmarkedsfenomen, fordi deltidens omfang, organisering, årsak og konsekvens varierer i ulike kontekster. I enkelte land og bransjer er det vanligere at deltidsansatte har en usikker og ustabil tilknytning. I litteraturen om deltid (se f.eks. O'Reilly \& Bothfeld 2002; Berglund et al. 2010; Nätti 1995) reises derfor ofte spørsmål om mobilitet: Fungerer deltidsarbeid som en «bro» inn i det ordinære, stabile arbeidsmarkedet, eller er det en «blindgate» som låser arbeidstakerne inn $\mathrm{i}$ en marginalisert posisjon? I forskningen benyttes også ofte et skille mellom normalisert og marginalisert deltid. Mens det normaliserte deltidsarbeidet gjerne er situert i det primære arbeidsmarkedet og i virksomhetenes kjernearbeidsstokk, finnes det marginaliserte deltidsarbeidet i større grad i det sekundære arbeidsmarkedet og virksomhetenes reservearbeidsstokk (Atkinson 
1984). Både empiriske og mer teoretisk orienterte studier har vist at det er stor forskjell i hvor integrert og likestilt disse to kategoriene av deltidsansatte er i arbeidsmarkedet (Nergaard 2010; Rubery, Ward \& Grimshaw 2006; Bosch 2006; Anxo et al. 2007). Skillet mellom frivillig og ufrivillig deltid behandles ofte som én av flere indikatorer på hvorvidt man har en marginalisert posisjon i arbeidslivet.

En implikasjon av disse innsiktene er at tilsynelatende likeartede tilpasninger til arbeidsmarkedet hos innvandrede og ikke-innvandrede kvinner kan tilsløre betydelige ulikheter. Arbeidstid har vært et lite belyst aspekt ved innvandrede kvinners økonomiske integrering i Norge, og i første del av artikkelen undersøker vi hva som karakteriserer arbeidstiden i ulike grupper, hvorvidt innvandrede kvinner er mer eller mindre tilbøyelige til å arbeide deltid enn norske kvinner, og $i$ hvilken grad det er variasjoner på dette området mellom innvandrede kvinner fra ulike land. Vi vil deretter bruke de mulighetene som registerpanelet gir til å analysere hvordan kvinnenes yrkesdeltakelse utvikler seg over tid. Hva kjennetegner kvinner som etablerer en mer omfattende tilknytning til arbeidslivet, og hva preger de som forsvinner ut? For å belyse disse spørsmålene vil vi ta utgangspunkt i forhold knyttet til kvinnenes human kapital, familiesituasjon og arbeidssituasjon.

Studier fra en rekke vesteuropeiske land viser at innvandreres økonomiske og kulturelle integrering varierer etter hvilket land de utvandret fra (se f.eks. Heath \& Demireva 2013 eller Longhi, Nicoletti \& Platt 2013 for UK; Kogan 2011 for Tyskland; Martinovic, van Tubergen \& Maas 2009 for Nederland). Vi har derfor valgt ut innvandrere fra enkelte land heller enn å basere oss på større, regionale grupper. Kvinner fra Irak, Iran, Pakistan, Somalia og Vietnam er tatt med fordi disse gruppene er tallmessig store nok til å analyseres separat, men også fordi de varierer i utdanningsnivå og yrkesdeltakelse og i holdninger til kvinners yrkesdeltakelse.

Kunnskap om innvandrede kvinners deltakelse i arbeidslivet er viktig av flere årsaker. For det første kan en ustabil eller marginal tilknytning til arbeidslivet både gi økonomiske problemer, og dårligere mulighet til å dra nytte av de arenaene for sosial kontakt og utvikling som arbeidslivet kan representere. For det andre er det behov for kunnskap om innvandrede kvinners situasjon i arbeidslivet for å 
kunne vurdere likestilling mellom kjønnene og eventuelle ulikheter mellom innvandrede og norske kvinner. Parrado og Flippen (2005:607-608) beskriver to teoretiske retninger innen forskning knyttet til kvinner og migrasjon. Den ene betrakter migrasjon som et frigjørende prosjekt som resulterer i flere muligheter og større likestilling for kvinner. I den andre retningen argumenteres det for at migrantenes liv er mest påvirket av klasse, etnisitet og selve migrasjonen, og at dette er viktigere enn kjønn for å forstå for eksempel deltakelsen i arbeidslivet. Mer kunnskap om hvordan innvandrede kvinners deltakelse $\mathrm{i}$ arbeidslivet utvikler seg over tid, kan utvide forståelsen av de teoretiske koblingene mellom kjønn, migrasjon, likestilling og økonomisk integrering.

For å berede grunnen for den empiriske analysen, vil vi på de neste sidene drøfte hvordan bidrag både fra litteraturen om arbeidstid og mobilitet, og fra litteratur om migranters økonomiske og kulturelle integrering, kan bidra til å belyse innvandrede kvinners integrering $\mathrm{i}$ arbeidslivet. Deretter beskriver vi data før analysene presenteres. Hovedfunn diskuteres avslutningsvis.

\section{TEORETISKE PERSPEKTIVER OG TIDLIGERE FORSKNING}

Både trekk ved arbeidsmarkedet og egenskaper ved kvinnene selv har betydning for hvem som er i arbeid, i hvilken grad og hvor lenge. Vi vil ta for oss tre vanlige perspektiver på kvinners arbeidstilknytning: human kapital, familiesituasjon og trekk ved arbeidsmarkedet, og diskutere dem opp mot foreliggende forskning om innvandrede kvinners økonomiske integrering.

HUMAN KAPITAL. Innvandreres økonomiske integrering studeres ofte med utgangspunkt i teoretiske tradisjoner som vektlegger betydningen av human kapital i form av individuelle ferdigheter og kvalifikasjoner (Becker 1964; Borjas 1995). Muligheten for å lykkes i arbeidsmarkedet knyttes her til hvor mye utdanning og arbeidserfaring innvandrere har med seg fra opprinnelseslandet, i hvilken grad denne kompetansen er kompatibel med krav som stilles i vertslandets arbeidsmarked, og hvilke investeringer innvandrere gjør for å opparbeide ny, landspesifikk human kapital. 
Sett under ett har innvandrede kvinner i Norge både lavere utdanning og mindre arbeidserfaring enn norske kvinner. ${ }^{3}$ Variasjonene er likevel store mellom landgrupper. Iranere har utdanning om lag på nivå med befolkningen for øvrig, og det er få forskjeller mellom kvinners og menns utdanningsnivå. Blant somaliske kvinner, som har vesentlig lavere utdanning enn somaliske menn, manglet 60 prosent grunnskole, og færre enn 5 prosent hadde høyere utdanning da de kom til Norge. Deltakelsen i det ordinære utdanningssystemet i Norge er lav. Også vietnamesiske kvinner har gjennomgående svært lav utdanning (46\% uten grunnskole), mens det blant irakere både er en betydelig andel kvinner med høy utdanning (26\%) og mange uten grunnskole $(26 \%)$. Blant pakistanske kvinner er det vanligste å ha utdanning på grunnskoles eller videregående skoles nivå - 12 prosent har høyere utdanning. Også tidligere arbeidserfaring varierer. Så mange som åtte av ti iranske og syv av ti vietnamesiske kvinner hadde et yrke i hjemlandet før de kom til Norge, mot bare to av ti kvinner fra Irak og Pakistan. Blant somaliske kvinner har derimot halvparten yrkeserfaring fra hjemlandet (Henriksen 2010). Kvinnene i vår studie har dermed svært ulike utgangspunkt i møtet med norsk arbeidsliv.

Empiriske analyser har vist en sammenheng mellom utdanning og innvandreres integrering $\mathrm{i}$ arbeidsmarkedet (se f.eks. Bratsberg, Raaum \& Røed 2012), men også at sammenhengen er svakere enn i majoritetsbefolkningen (Hardoy \& Schøne 2008) og at den finnes i mindre grad for kvinner enn for menn (Adsera \& Chiswick 2007). Drange (2009:176) finner at sannsynligheten for å være heltidssysselsatt øker med utdanningens lengde hos både norske og innvandrede kvinner, men også at sammenhengen mellom utdanning og arbeidstid er svakere for kvinner som selv har innvandret enn for kvinnelige etterkommere og kvinner med norsk bakgrunn. Migrasjonsforskere har lett etter forklaringer på slike forskjeller blant annet med utgangspunkt i teorier om «landspesifikk human kapital» (Borjas 1995). Begrepet henviser til kapital som i liten grad lar seg overføre fra én nasjonal kontekst til en annen. Begrenset kunnskap om det nye landets språk og arbeidsmarked samt andre krav til yrkeskompetanse enn i opprinnelseslandet kan bidra til å redusere verdien av medbrakt human kapital (Chiswick, Lee \& Miller 2005:334-335). Samtidig reduseres gjerne disse ulempene over tid, fordi innvandrerne tilegner 
seg flere av de ferdigheter som etterspørres (Friedberg 2000; Chiswick \& Miller 2010).

Vi forventer at kvinner med høy utdanning i mindre grad arbeider deltid enn kvinner med lav utdanning og at de dessuten vil ha en mer stabil tilknytning til arbeidslivet. De har investert i utdanning, og har mer å tape økonomisk på å redusere arbeidstiden fordi det kan bremse videre karriere og lønnsutvikling. Kvinner med høy utdanning vil trolig også være bedre rustet til å tilegne seg ferdigheter de måtte mangle for å finne en jobb, beholde den og eventuelt øke arbeidstiden. I lys av Dranges (2009) funn om at sammenhengen mellom utdanning og heltidsarbeid er svakere blant innvandrede enn blant norske kvinner, kan det likevel hende at høy utdanning betyr mindre både for arbeidstid og for stabiliteten i sysselsetting blant innvandrede enn blant norske kvinner. De fleste vil også trenge noe tid for å lære norsk og etablere et nettverk i det lokale arbeidslivet. Vi forventer derfor at risikoen for å gå ut av lønnet arbeid vil synke med økt botid og at lengre botid vil øke kvinnenes mulighet til å tette et eventuelt gap mellom faktisk og ønsket arbeidstid. Samtidig vil kvinner med lang botid kanskje allerede ha oppnådd den arbeidstiden de ønsker, og betydningen av økt botid vil i så fall bli mindre over tid.

\section{FAMILIEFASE OG HOLDNINGER TIL KVINNERS YRKESDELTA-}

KELSE. Kvinners deltakelse i arbeidslivet varierer med familietype og familiefase både blant innvandrere (Kavli \& Nadim 2009) og i befolkningen sett under ett (Ellingsæter 2009). Sammenliknet med menn reduserer kvinner sitt lønnsarbeid i større grad, over lengre tid og oftere midt i karrieren. I den grad menn jobber deltid skjer dette gjerne i forbindelse med oppstart og avslutning av yrkeslivet (O'Reilly \& Fagan 1998; Yerkes \& Visser 2006). Studier, både i England (Holdsworth \& Dale 1998; Dale, Shaheen, Kalra \& Fieldhouse 2002) og i Nederland (Bevelander \& Groeneveld 2006), tyder likevel på at implikasjonene av sentrale livshendelser som det å gifte seg eller å få barn kan være ulike i ulike etniske grupper. Holdsworth og Dale (1997) fant for eksempel at mens det å gifte seg var sterkt assosiert med redusert yrkesdeltakelse blant innvandrede kvinner fra Pakistan og Bangladesh, var det å ha små barn (under skolealder) det mest avgjørende for om britiske kvinner reduserte sin arbeidstid. Forskerne 
knytter dette til at kvinner med ulik landbakgrunn har ulike holdninger til organisering av familielivet.

I Norge er slike variasjoner i holdninger etter hvert godt dokumentert (Kavli 2015). Innvandrere fra Iran, Irak, Pakistan, Somalia og Vietnam er mindre positive til at mødre deltar i lønnet arbeid mens de har små barn enn befolkningen for øvrig. Dersom mødre skal jobbe i småbarnsfasen, trekkes gjerne deltid fram som den beste løsningen. Samtidig er det betydelige variasjoner i holdninger blant innvandrere fra ulike land. Pakistanere, irakere og somaliere er gjennomgående mer negative til mødres yrkesdeltakelse enn innvandrere fra Iran og Vietnam (Kavli 2004, 2015). I landgrupper med restriktive holdninger til mødres yrkesaktivitet er det også vanligere å ønske seg mange barn (Kavli \& Nadim 2009:29).

Dersom kjønnstradisjonelle holdninger omsettes til praksis, vil det ha større konsekvenser for kvinners yrkesdeltakelse jo flere barn familien får. Norske kvinner får i gjennomsnitt 1,8 barn (2010-2012). Blant innvandrede kvinner varierer fertiliteten fra 1,4 blant kvinner fra Iran til 2,1 blant kvinner fra Vietnam, 3,1 blant kvinner fra Irak og Pakistan og 3,9 blant kvinner fra Somalia (Tønnessen 2014:4348). Samtidig er forholdet mellom holdninger og verdier på den ene siden, og kvinners lønnsarbeid på den andre, gjenstand for debatt. Hakim $(1991,2006)$ hevder at kvinners mulighet til å realisere sine preferanser har økt i takt med økende individualisering i vestlige samfunn. Kjønnsforskjellene i tilpasningen til lønns- og omsorgsarbeid kan ifølge henne derfor langt på vei tilskrives forskjeller i menns og kvinners preferanser. Andre hevder at det er lite fruktbart å fortolke ulik atferd som uttrykk for preferanser uten samtidig å ta hensyn til strukturelle og institusjonelle faktorer som omgir kvinner og legger rammer for deres tilpasninger til lønns- og omsorgsarbeid (se f.eks. Crompton \& Harris 1998; Halrynjo \& Lyng 2009). I en familie der mor har lave inntjeningsmuligheter i arbeidsmarkedet, vil for eksempel kostnadene til barnepass heve terskelen for når det vil være økonomisk lønnsomt for familien at begge foreldrene jobber, uavhengig av hva mor eller far mener om mødres yrkesdeltakelse. De fleste er i dag likevel enige om at både strukturer og holdninger hører hjemme i en analyse av kvinners yrkesdeltakelse. Vi forventer at kvinner med små barn i mindre grad vil øke sin arbeidstid enn kvinner uten små 
barn, og at de i større grad vil gå ut av lønnet arbeid. I lys av forskjeller i holdninger til mødres yrkesdeltakelse, forventer vi samtidig at det å ha små barn vil ha ulik betydning for kvinners yrkesdeltakelse $\mathrm{i}$ ulike landgrupper.

ARBEIDSMARKED OG ARBEIDSTID. Hva slags tilknytning kvinner etablerer til arbeidslivet og hvilke deler av arbeidslivet de beveger seg inn i, kan ha stor betydning for videre økonomisk integrering. Innvandrede kvinners yrkesdeltakelse er imidlertid sjelden belyst ut over det mest grunnleggende - om de har lønnet arbeid eller ikke. Et unntak er Rubin (2008:18-19), som finner at innvandrede kvinner i en rekke europeiske land har en mer marginalisert posisjon i arbeidsmarkedet enn både innvandrede menn og kvinner fra majoritetsbefolkningen. I Sverige og Danmark er de både mer utsatt for ufrivillig deltid og for midlertidige ansettelser. Også i Norge er innvandrede arbeidstakere mer utsatt for ufrivillig deltid enn norske: I 2011 ble 21 prosent av deltidsansatte arbeidstakere med bakgrunn fra Afrika og Asia regnet som undersysselsatt, mot om lag 10 prosent i befolkningen sett under ett (Bø 2013:11).

Forskning på hvorvidt opphopning av deltid i enkelte bransjer skyldes trekk ved produksjonsforholdene eller trekk ved de ansatte, peker ofte i flere retninger. Dels er deltiden ønsket av arbeidstakerne, dels er det gunstig ut fra trekk ved produksjonen, og dels bidrar arbeidsgivere til å forme yrkesbestemte deltidskulturer (Abrahamsen 2009; Horrell \& Rubery 1991; Kjelstad \& Nymoen 2004; Nicolaisen 2013; Thomlinson 2006). Uansett hva årsaken til bransjeforskjellene er, ser det ut til at «deltid avler deltid». Når deltid først har blitt vanlig i en bransje, preger det arbeidsorganiseringen ved at nye stillinger ofte lyses ut som deltid og ved at produksjonen er organisert rundt en deltidsnorm. Dette kan begrense arbeidstakernes mulighet for å øke arbeidstiden. Typiske deltidsbransjer har også høyest forekomst av ufrivillig deltid (Kjelstad 2006:536).

Innvandrede kvinner er i Norge overrepresentert i typiske deltidsbransjer. Litt over halvparten av alle sysselsatte kvinner fra Asia og Afrika er ansatt enten som renholdere (17,4\%), barne- og ungdomsarbeidere $(9,4 \%)$, butikkmedarbeidere $(9,2 \%)$, pleieassistenter $(7,7 \%)$ eller hjelpepleiere/omsorgsarbeidere $(7,3 \%)$ (NOU 
2012:15). Det er rimelig å anta at dette vil prege arbeidsdeltakelsen blant innvandrede kvinner i form av høye deltidsandeler. For kvinner som ønsker å øke arbeidstiden, kan jobb i en typisk deltidsbransje også være en barriere. Böheim og Taylor (2004:149) finner at det de betegner som «rigiditeten i arbeidsmarkedet» begrenser britiske arbeidstakeres muligheter for å oppnå ønsket arbeidstid. A bytte arbeidsgiver, og for kvinners del også å bytte stilling hos samme arbeidsgiver, bidrar til større sammenfall mellom ønsket og reell arbeidstid. Å bytte jobb kan dermed være positivt for en arbeidstaker som ønsker å bedre arbeidsvilkårene, herunder arbeidstid. Samtidig kan bytte av jobb også være ufrivillig og et uttrykk for en ustabil tilknytning til arbeidslivet. Innvandrede arbeidstakere, spesielt med bakgrunn fra Afrika og Asia, er overrepresentert i midlertidige stillinger (Bø 2013:9), og det er dermed ikke gitt at det å bytte jobb alltid er frivillig eller del av en strategi for å oppnå økt arbeidstid. Vi forventer likevel at stillingsbytte i hovedsak vil øke sannsynligheten for å gå fra del- til heltidsstilling. Også stabiliteten i arbeidstilknytning kan variere med arbeidstid. Spesielt korte deltidsbrøker henger ofte statistisk sammen med en større bevegelse ut av lønnet arbeid, samt undersysselsetting, lav lønn, dårlig integrering på arbeidsplassen og få karrieremuligheter (Messenger 2006:429). Vi forventer derfor at risikoen for å gå ut av lønnet arbeid mellom 2009 og 2012 vil være større jo kortere arbeidstid kvinnene har i 2009.

\section{ANALYTISK DESIGN, DATA OG METODER}

Vår ambisjon er å belyse hvordan deltakelsen i arbeidsmarkedet utvikler seg over en treårs periode blant kvinner med ulik landbakgrunn. Hvem har en stabil tilknytning til arbeidslivet, hvem forsvinner ut av arbeidslivet, og hva kjennetegner de som øker arbeidstiden? Spørsmålene blir analysert både ved at norske og innvandrede kvinner sammenliknes, og gjennom egne analyser kun blant innvandrere. Tabell 1 viser hvordan kvinner i ulike landgrupper fordeler seg $i$ henhold til human kapital, familiesituasjon og trekk ved arbeidsforholdet. Vi har deretter benyttet binær, logistisk regresjon for å belyse sannsynligheten for å arbeide deltid i 2009 (tabell 2), samt for to typer overganger mellom 2009 og 2012 - ut av arbeidslivet (tabell 3), og fra deltid til heltid (tabell 4). Analysene er gjennomført med data 
fra arbeidstakerregisteret, påkoblet informasjon om blant annet landbakgrunn, utdanning og familiesituasjon. Registerdataene oppdateres årlig, og dette gjør at vi kan følge samme individ over flere år.

UTVALG. Utvalget består av alle kvinner i alderen 25-54 år 4 som var innvandret til Norge fra Iran, Irak, Pakistan, Somalia eller Vietnam og var sysselsatt per 1. november 2009. En person regnes som innvandrer dersom hun er født i utlandet av to utenlands fødte foreldre. Norske kvinner uten innvandringsbakgrunn er referansegruppe. I analyser kun av innvandrere er vietnamesiske kvinner referansegruppe. Yrkesdeltakelse varierer betydelig etter landbakgrunn, og påvirker dermed sammensetningen av utvalget. Blant kvinner i aldersgruppen 25-54 år var andelen i lønnet arbeid per november 2009 som følger: Norge (83), Irak (33), Iran (56), Pakistan (32), Somalia (23) og Vietnam (64).

Selvstendig næringsdrivende vil vanligvis råde over egen arbeidstid i større grad enn ansatte og er derfor tatt ut av materialet. Vi har også fjernet personer med flere enn ett (samtidig) arbeidsforhold fordi vi ønsket å studere mobilitet $\mathrm{i}$ arbeidstid og kun har informasjon om arbeidstid i hovedarbeidsforholdet. Ifølge Kjelstad og Nymoen (2004:38) er deltid noe vanligere blant arbeidstakere med flere arbeidsforhold, men de arbeider da gjerne i lang deltid. Personer med kort deltid eller heltidsarbeid har sjelden flere arbeidsforhold. Ved å ta ut ansatte med flere stillinger, vil vi dermed underestimere andelen med lang deltid noe. Denne underestimeringen vil være litt mer omfattende blant de innvandrede kvinnene enn blant de norske. På referansetidspunktet hadde 10 prosent av de kvinnelige arbeidstakerne i alderen 25-54 år med bakgrunn fra Asia og Afrika, og 8 prosent blant norske kvinner, flere enn ett arbeidsforhold. I den grad det å ha flere stillinger er et resultat av ufrivillig deltid, og dersom slik ufrivillig deltid er midlertidig, vil det å fjerne denne gruppen fra analysen medføre at vi undervurderer hvor vanlig det er å øke arbeidstiden. Antall personer i den endelige analysepopulasjonen framgår av tabell 1 .

VARIABLER. Kategorien «human kapital» omfatter utdanning, landbakgrunn, botid i Norge og alder. Blant innvandrere har mange tatt utdanningen sin før de kom til Norge, og det mangler registerinfor- 
masjon om utdanning spesielt for de nyeste gruppene av flyktninger. Utdanningsnivå er derfor delt i kun fire - høy, middels, lav og ukjent. Landbakgrunn og botid er plassert i kategorien 'human kapital' av flere årsaker. $\AA$ være født i Norge kan representere en arbeidsmarkedsressurs enten i form av (positive) holdninger til kvinners yrkesaktivitet (Kitterød, Rønsen \& Seierstad 2013), større sosialt nettverk i norsk arbeidsliv, eller utdanning som er tilpasset norske forhold og kjent av norske arbeidsgivere. Botid er inkludert som en kontinuerlig variabel. For å ta høyde for at tilegnelsen av landspesifikk human kapital tenkes å stige i en del år, for deretter å avta eller synke, legges botid også inn i form av et annengradsledd. Alder er inkludert som kontinuerlig variabel og i form av et annengradsledd.

Kategorien familiesituasjon omfatter variabler knyttet til samlivsstatus og barn. Sivil status er avgrenset til kategoriene ugift (referansekategori), gift/partner, og skilt/enke. Kvinner som har barn mellom null og fem år holdes opp mot kvinner med barn i alderen seks-elleve år, tolv år + eller som ikke har barn. ${ }^{5}$ Endring av sivil status og barn født mellom 2009 og 2012 er lagt inn som dummyvariabler.

Arbeidstid er delt inn i tre kategorier basert på ukentlig, avtalt arbeidstid: kort deltid (4-19 timer), lang deltid (20-29 timer) og heltid (30 timer +). Faktisk arbeidstid kan både være noe høyere og noe lavere enn det som er avtalt. Kvinner som arbeidet 30 timer eller mer per uke er kategorisert som heltidsarbeidende. Full stilling tilsvarer vanligvis 37,5 timer per uke, noe som betyr at vår heltidskategori omfatter enkelte arbeidstakere med mellom 80 og 90 prosents stillinger. ${ }^{6}$ Kategorien «arbeidsliv» inkluderer også variablene yrkeskategori og antall ansatte på arbeidsplassen. Arbeidstakerne er samlet i seks hovedgrupper av yrkesfelt med utgangspunkt i Norsk standard for yrkesklassifisering (STYRK). Bytte av yrke lagt inn som en dummyvariabel der verdien 1 omfatter arbeidstakere som hadde en annen yrkeskode i 2012 enn i 2009. Forekomsten av deltid varierer innenfor ulike typer av virksomheter i samme bransjer. Deltid er mer utbredt i store enn i små virksomheter, men det er også i de store virksomhetene at det er størst mobilitet fra del- til heltid (Kjelstad \& Nymoen 2004:32; Nergaard 2010). Arbeidsplassens størrelse er basert på en tredeling: 1-19 ansatte (referansekategori), 20-99 ansatte og 100 eller flere ansatte. 
DESKRIPTIV STATISTIKK . I tabell 1 tar vi utgangspunkt i kvinner som var i lønnet arbeid november 2009 og beskriver forhold knyttet til human kapital, familiesituasjon og trekk ved arbeidsplassen innenfor hver landgruppe. Norske, og til dels iranske kvinner har i gjennomsnitt høyere utdanning enn kvinner fra Irak, Pakistan og Vietnam. Blant kvinner fra Somalia er utdanningsnivået spesielt lavt, selv her hvor utgangspunktet er kvinner i lønnet arbeid. Blant kvinner fra Pakistan og Vietnam er gjennomsnittlig botid henholdsvis 19 og 18 år, mot bare 9 og 11 år blant kvinner fra Irak og Somalia. Norske kvinner er oftere ugift enn kvinner i de øvrige landgruppene. Familiesituasjonen er likevel likere enn det sivil status skulle tilsi, fordi norske kvinner oftere er samboere og oftere får barn mens de lever i samboerskap (Daugstad 2008). Både det å ha barn under seks år, og å ha fått barn i løpet av analyseperioden, er mer vanlig blant kvinner fra Irak, Somalia og Pakistan enn blant kvinner fra Norge, Vietnam og Iran. Andelen kvinner som er skilt, separert eller enke er vesentlig høyere blant somaliere og irakere enn blant de øvrige gruppene.

Yrkesklassifiseringen illustrerer at ikke-vestlige innvandrere er overrepresentert $\mathrm{i}$ noen deler av arbeidslivet og underrepresentert $\mathrm{i}$ andre. Samtidig ser vi også betydelige, og potensielt viktige, forskjeller mellom landgruppene. Innvandrere er underrepresentert i lederyrker og i yrker med krav om kortere høyskole- eller universitetsutdanning. Kvinner fra Iran er likevel langt sterkere representert i disse yrkene enn kvinner fra de øvrige landgruppene, noe som trolig henger sammen med at dette er en gruppe der flere har høy utdanning. Innvandrere er gjennomgående overrepresentert blant de som jobber i pleie og omsorg. Størst utslag ser vi i den somaliske gruppen der over halvparten av kvinnene var ansatt innen pleie og omsorg. Vietnamesiske kvinner er derimot i liten grad ansatt i slike yrker, men er desto sterkere representert i kontor- og kundeserviceyrker. Samtlige av de innvandrede gruppene er kraftig overrepresentert innen yrker uten krav til utdanning - vanligvis renhold. Om lag tre av ti byttet yrke mellom 2009 og 2012 - kvinner fra Irak i noe høyere grad enn andre. 
TABELL 1. Deskriptiv statistikk. Kvinner i lønnet arbeid, etter landbakgrunn. 2009*

\begin{tabular}{|c|c|c|c|c|c|c|}
\hline & Norge & Irak & Iran & Pakistan & Somalia & Vietnam \\
\hline \multicolumn{7}{|l|}{ HUMAN KAPITAL } \\
\hline Høy utdanning & 47,1 & 24,5 & 42,6 & 20,5 & 11,6 & 24,3 \\
\hline Middels utdanning & 38,6 & 20,3 & 28,8 & 24,8 & 26,6 & 29,0 \\
\hline Lav/ingen utdanning & 14,2 & 36,4 & 21,7 & 42,5 & 51,9 & 35,9 \\
\hline Uoppgitt utdanning & 0,1 & 18,8 & 6,9 & 12,2 & 9,8 & 10,8 \\
\hline Botid (gjennomsnitt) & .. & 9,1 & 13,8 & 18,9 & 11,2 & 17,8 \\
\hline Alder (gjennomsnitt) & 40 & 36 & 38 & 36 & 35 & 38 \\
\hline \multicolumn{7}{|l|}{ FAMILIESITUASJON } \\
\hline Ugift & 37,8 & 8,8 & 19,5 & 8,6 & 25,5 & 19,5 \\
\hline Gift/partner & 49,1 & 79,5 & 56,9 & 77,4 & 43,2 & 64,2 \\
\hline Skilt/separert/enke & 13,1 & 11,7 & 23,7 & 13,9 & 31,3 & 16,2 \\
\hline Ingen barn & 21,0 & 18,1 & 32,5 & 22,5 & 33,3 & 24,8 \\
\hline Yngste barn opp t.o.m. 5 år & 22,8 & 43,8 & 22,0 & 32,7 & 32,8 & 30,4 \\
\hline Yngste barn 6-11 & 19,0 & 21,9 & 18,5 & 22,6 & 20,0 & 21,3 \\
\hline Yngste barn 12 år + & 37,1 & 16,1 & 27,0 & 22,2 & 13,9 & 23,6 \\
\hline Giftet seg 2009-2012 & 3,7 & 2,5 & 4,5 & 4,5 & 4,3 & 3,5 \\
\hline Fått barn mellom 2009 og 2012 & 8,8 & 19,9 & 8,9 & 17,1 & 19,9 & 11,8 \\
\hline Blitt skilt/enke mellom 2009 og 2012 & 1,9 & 3,3 & 4,9 & 2,7 & 5,4 & 4,4 \\
\hline \multicolumn{7}{|l|}{ ARBEIDSLIV } \\
\hline 1-19 ansatte & 30,3 & 35,7 & 31,0 & 38,5 & 13,0 & 31,1 \\
\hline 20-99 ansatte & 38,7 & 37,0 & 31,9 & 31,7 & 42,2 & 31,3 \\
\hline $100+$ ansatte & 31,0 & 27,3 & 37,1 & 29,8 & 44,8 & 37,6 \\
\hline $\begin{array}{l}\text { Adm. ledere, politikere, akadem. } \\
\text { yrker }(1,2)\end{array}$ & 21,1 & 8,1 & 17,0 & 5,8 & 1,6 & 7,9 \\
\hline $\begin{array}{l}\text { Yrker m/kortere høysk. el. univ.utd, } \\
\text { tekn. (3) }\end{array}$ & 32,1 & 7,6 & 23,3 & 12,5 & 8,0 & 13,4 \\
\hline $\begin{array}{l}\text { Kontor- \& kundeserviceyrker, transport- } \\
\text { og maskinoperatører }(4,8)\end{array}$ & 13,1 & 10,0 & 6,8 & 11,5 & 3,5 & 25,1 \\
\hline Pleie- og omsorgspersonale (5) & 19,3 & 35,1 & 30,2 & 35,9 & 56,7 & 12,5 \\
\hline $\begin{array}{l}\text { Salgs-, service- \& øvrige omsorgsyrker } \\
(5,6,7,0)\end{array}$ & 10,5 & 16,7 & 15,3 & 18,2 & 3,8 & 19,3 \\
\hline $\begin{array}{l}\text { Yrker u/krav til utdanning, bl.a. } \\
\text { renhold (9) }\end{array}$ & 3,9 & 22,5 & 7,5 & 16,1 & 26,4 & 21,7 \\
\hline Byttet yrke mellom 2009 og 2012 & 32,9 & 32,8 & 38,7 & 29,0 & 29,1 & 30,6 \\
\hline $\mathrm{N}$ & 536.248 & 1.202 & 1.811 & 1.456 & 790 & 2.519 \\
\hline
\end{tabular}

* Alle statusvariabler refererer til 2009 med mindre annet er spesifisert. 


\section{ARBEIDSTID BLANT INNVANDREDE KVINNER}

Blant kvinner som er i lønnet arbeid, kan arbeidstid både brukes som en (grov) indikasjon på hvor tett tilknytningen til arbeidslivet er og som et utgangspunkt for videre analyse av mobilitet i arbeidstilknytning. Figur 1 viser at avtalt arbeidstid varierer betydelig mellom kvinner fra ulike land. Blant vietnamesere arbeider om lag én av fire deltid - noe som er på nivå med norske kvinner - og andelen med korte deltidsbrøker er lav. På det motsatte ytterpunktet finner vi somaliere, der over halvparten arbeider deltid og flertallet har korte deltidsbrøker. Også blant kvinner fra Irak, Iran og Pakistan er andelen med kort avtalt arbeidstid vesentlig høyere enn blant norske kvinner.

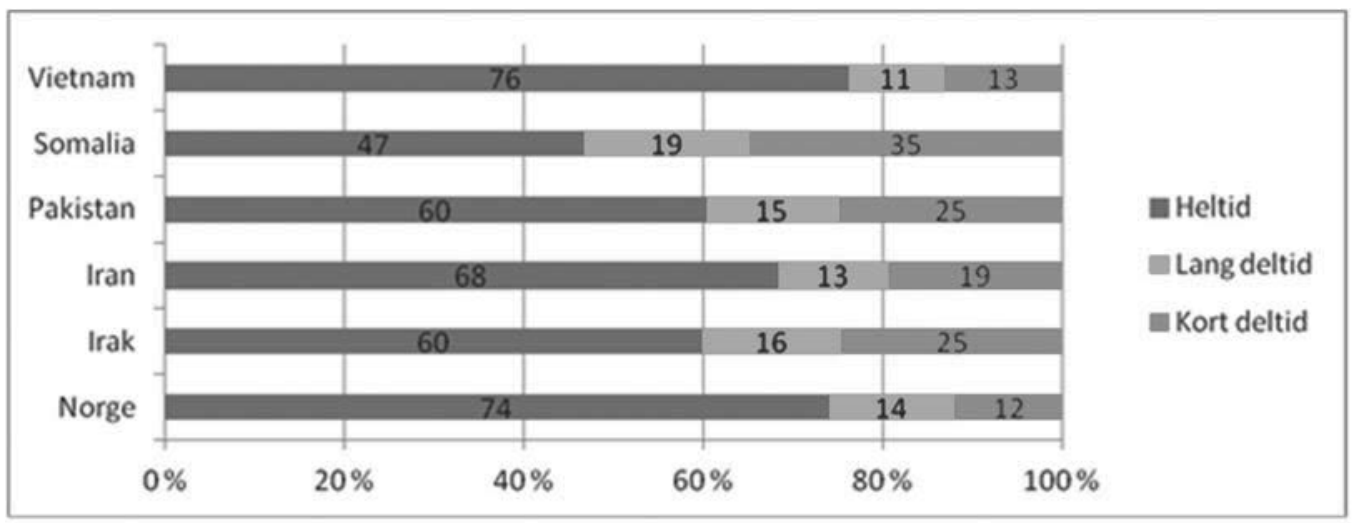

FIGUR 1. Kvinners arbeidstid i 2009, etter landbakgrunn

Tabell 2 tar utgangspunkt i sysselsatte kvinner i alderen 25-54 år, og viser sannsynligheten for å ha en deltidsstilling (4-29 timer per uke) sammenliknet med å jobbe $\mathrm{i}$ en fulltidsstilling (30 timer eller mer). Modellen er bygget trinnvis. I første trinn introduseres variabler knyttet til human kapital og familiesituasjon (modell 1a). Her ser vi at kvinner fra Irak, Iran, Pakistan og Somalia har høyere sannsynlighet for å arbeide deltid enn norske kvinner, også etter at det er tatt hensyn til variasjoner i utdanning, alder, sivil status og yngste barns alder. Vietnamesiske kvinner har derimot lavere sannsynlighet enn norske kvinner for å arbeide deltid. Sannsynligheten for å arbeide deltid synker jo høyere utdanning kvinnen har, men forskjellene i deltidsandeler mellom landgrupper lar seg altså ikke forklare med at innvandrede kvinner gjennomgående har lavere utdanning enn norske kvinner uten innvandringsbakgrunn. 
Når vi i regresjonens andre trinn introduserer trekk ved arbeidsplassen, endrer bildet seg (modell 1b). Etter kontroll for yrke og arbeidsplassens størrelse har både vietnamesiske, irakiske og pakistanske kvinner lavere sannsynlighet for å arbeide deltid enn norske kvinner. Bare somaliske kvinner har fortsatt høyere deltidstilbøyelighet enn norske, mens det ikke er noen statistisk sikker forskjell mellom norske og iranske kvinner. Yrke er den klart sterkeste prediktoren for deltid, og resultatene tilsier at innvandrede kvinners overrepresentasjon i typiske deltidsyrker er viktig å ta hensyn til når vi skal analysere deres integrering i arbeidslivet. $^{7}$ Våre resultater er her i tråd med liknende studier i Nederland og England som viser at deltidsandelen blant innvandrede kvinner i hovedsak er lavere enn i befolkningen for øvrig (Bevelander \& Groeneveld 2006:805; Holdsworth \& Dale 1997), når man samtidig tar hensyn til yrke (England) og familiesituasjon (England og Nederland).

TABELL 2. Odds ratio estimater for å vore ansatt $i$ deltid vs. heltid. Kvinner 25-54 år. Bincer, logistisk regresjon

\begin{tabular}{|c|c|c|}
\hline & $\begin{array}{l}\text { Modell 1a } \\
\text { Exp (B) }\end{array}$ & $\begin{array}{c}\text { Modell 1b } \\
\operatorname{Exp}(B)\end{array}$ \\
\hline \multicolumn{3}{|c|}{$\begin{array}{l}\text { HUMAN KAPITAL } \\
\text { Landbakgrunn (ref: Norge) }\end{array}$} \\
\hline Irak & 1,199 & ,792 \\
\hline Iran & 1,231 & ,963 \\
\hline Pakistan & 1,203 & ,864 \\
\hline Somalia & 2,379 & 1,452 \\
\hline Vietnam & ,649 &, 540 \\
\hline \multicolumn{3}{|c|}{ Lav/ingen utdanning (ref) } \\
\hline Middels & ,757 & ,831 \\
\hline Нøу & 429 & 1,248 \\
\hline Uoppgitt & 891 & ,975 \\
\hline Alder & 817 & 872 \\
\hline Alder kvadrert & 1,002 & 1,002 \\
\hline \multicolumn{3}{|l|}{ FAMILIESITUASJON } \\
\hline \multicolumn{3}{|l|}{ Sivilstatus (Ref: ugift) } \\
\hline Gift/partner & 1,334 & 1,437 \\
\hline Skilt/separert/enke & ,898 & ,918 \\
\hline \multicolumn{3}{|c|}{ Yngste barns alder (ref: ingen barn) } \\
\hline Opp til 5 år & 1,716 & 1,745 \\
\hline 6-11 år & 1,860 & 1,731 \\
\hline 12 år + & 1,441 & 1,266 \\
\hline
\end{tabular}


TABELL 2. Odds ratio estimater for å vore ansatt $i$ deltid $v$ s. heltid.

Kvinner 25-54 år. Bincer, logistisk regresjon (forts.)

\begin{tabular}{lrr}
\hline & $\begin{array}{c}\text { Modell 1a } \\
\text { Exp (B) }\end{array}$ & $\begin{array}{c}\text { Modell 1b } \\
\text { Exp (B) }\end{array}$ \\
\hline ARBEIDSLIV & & \\
Antall ansatte (ref: 1-19) &, $\mathbf{8 6 1}$ \\
$20-49$ & $\mathbf{1 , 1 2 6}$ \\
$50-99$ & $\mathbf{1 , 1 7 6}$ \\
$100+$ & \\
Yrkeskategori (ref: Adm. ledere, politikere, akad.yrker (1,2) & $\mathbf{2 , 3 1 9}$ \\
Yrker m/kortere høysk. el. univ.utd, tekn.(3) & $\mathbf{2 , 9 5 5}$ \\
Kontor- \& kundeserviceyrker, transport- og maskinoperatører (4,8) & $\mathbf{1 1 , 4 8 6}$ \\
Pleie- og omsorgspersonale (5) & $\mathbf{9 , 7 7 1}$ \\
Salgs-, service- \& øvrige omsorgsyrk. (5,6,7,0) & $\mathbf{9 , 8 7 6}$ \\
Yrker u/krav til utdanning, bl.a. renhold (9) & \\
& & \\
Konstantledd & $\mathbf{6 7 9}$ \\
Nagelkerke R2 & $\mathbf{1 9 , 6 5 0}$ & 0,177 \\
\hline Note: Odds-rater på over 1 viser en positiv sammenheng, under 1 negativ. Alle uthevde sammenhenger er \\
signifikante på minst 5 prosents nivå. & &
\end{tabular}

\section{ARBEIDSTID OG EXIT FRA LØNNET ARBEID}

Innvandrede kvinner har en langt mer ustabil tilknytning til arbeidslivet enn norske kvinner. Mellom 2009 og 2012 forsvant 10 prosent av de norske kvinnene ut av lønnet arbeid. Blant vietnamesiske og iranske kvinner var tilsvarende andel hhv. 20 og 25 prosent, mens hele 34 prosent blant pakistanske og 40 prosent blant irakiske og somaliske kvinner stod uten arbeid i 2012. Figur 2 illustrerer at arbeidstid og stabilitet $\mathrm{i}$ arbeidstilknytning er nær relatert. Både blant norske og innvandrede kvinner er andelen uten lønnet arbeid i 2012 større jo kortere den avtalte arbeidstiden var i 2009. Samtidig er bevegelsen ut av lønnet arbeid langt mer omfattende blant innvandrede enn blant norske kvinner. Nesten halvparten av irakiske og somaliske kvinner med korte deltidsstillinger i 2009 stod uten arbeid tre år senere. Blant norske kvinner var den tilsvarende andelen noe over 20 prosent, mens den blant vietnamesiske og iranske kvinner var henholdsvis 33 og 40 prosent. 


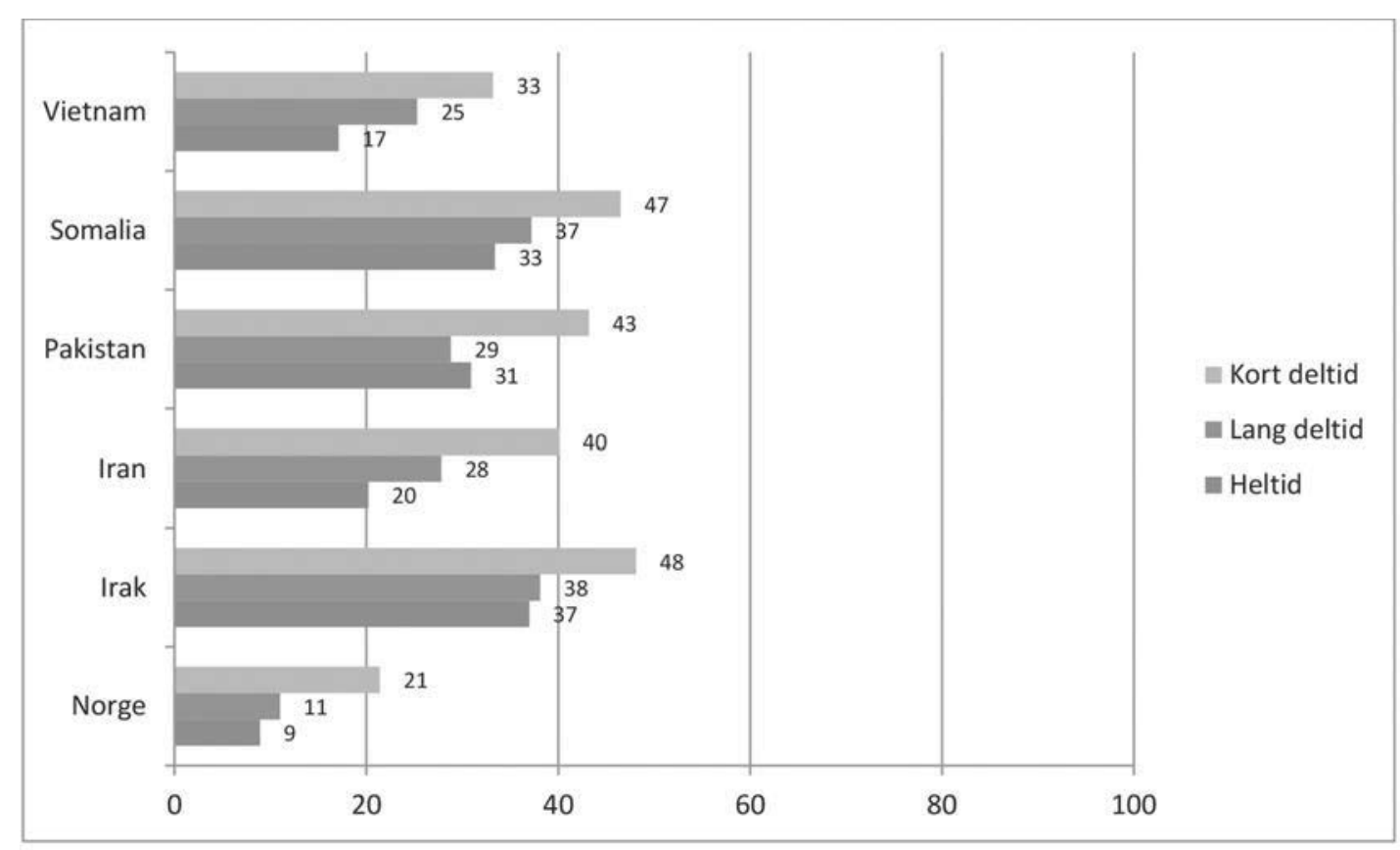

FIGUR 2. Andel kvinner uten lønnet arbeid i 2012, etter arbeidstid $i 2009$ og landbakgrunn

I tabell 3 tar vi utgangspunkt i alle sysselsatte kvinner i 2009 og viser sannsynligheten for å være uten lønnet arbeid tre år senere, i 2012. Som forventet har både innvandrede og norske kvinner med høy utdanning en mer stabil tilknytning til arbeidslivet enn kvinner med lavere utdanning (modell 2). For å teste om sammenhengen mellom høy utdanning og stabil arbeidstilknytning er svakere for innvandrede enn for norske kvinner, gjennomførte vi samspillsanalyser (online appendiks). De tyder på at høy utdanning reduserer sannsynligheten for å gå ut av lønnet arbeid i noe større grad blant iranske enn blant norske kvinner. Ut over dette var ingen av samspillsleddene signifikante. Resultatene støtter imidlertid opp om antagelsen at økt botid kan gi mer landspesifikk human kapital som i neste omgang kan styrke posisjonen på arbeidsmarkedet: kvinner med lang botid i Norge har en mer stabil tilknytning til arbeidslivet enn kvinner med kortere botid (modell 3).

Både inngåelse av ekteskap og skilsmisse ${ }^{8}$ øker sannsynligheten for exit fra arbeidslivet i utvalget sett under ett (modell 2), men er ikke signifikant i minoritetsutvalget (modell 3). Det å ha fătt barn mellom 2009 og 2012 øker imidlertid sannsynligheten for å gå ut av lønnet 
arbeid, både blant norske og innvandrede kvinner. Også blant kvinner som hadde barn under seks år i 2009, var den relative sannsynligheten for å stå uten lønnet arbeid i 2012 høyere enn blant kvinner med eldre barn. Forholdet mellom omsorgsoppgaver og stabiliteten i kvinners yrkesdeltakelse er dermed i tråd med hva vi kunne forvente. For å undersøke om omsorgsoppgaver har ulik betydning for kvinner med ulik landbakgrunn, har vi gjennomført samspillsanalyser (online appendiks). De indikerer at å ha barn under seks år øker sannsynligheten for å gå ut av lønnet arbeid i noe større grad blant pakistanske og irakiske enn blant norske kvinner. I de øvrige landgruppene er samspillsleddet enten ikke signifikant eller svært følsomt for ulike operasjonaliseringer. ${ }^{9}$ I lys av at flere av innvandrergruppene har langt mer restriktive holdninger til mødres yrkesaktivitet i småbarnsfasen enn nordmenn, skulle man anta at forskjellene ville være større. At vi ikke finner mer kan skyldes at kvinner som tilhører en landgruppe der få kvinner er i lønnet arbeid, skiller seg fra andre i sin gruppe med en sterk yrkesorientering. På den annen side bør det også nevnes at holdninger og praksis ikke alltid følger hverandre og at særlig kjønnstradisjonelle holdninger knyttet til familiens forsørgelse kan være utfordrende å etterleve i et samfunn der svært mye er bygget opp rundt idealet om to-inntektsfamilien (Kavli 2004).

I tråd med hva vi forventet er risikoen for exit fra arbeidslivet høyere for kvinner med kort enn for kvinner med lang arbeidstid. Vi finner imidlertid ikke at deltidsansettelse reduserer stabiliteten i arbeidstilknytningen i ulik grad for kvinner fra ulike landgrupper (samspillsanalyser, online appendiks). Risikoen for å stå uten arbeid $\mathrm{i}$ 2012 er lavere jo flere ansatte det var på arbeidsplassen i 2009. Vi finner også at ansatte i salgs-, service- og omsorgsyrker og ansatte innen renhold og hjelpearbeid har en høyere exit-risiko enn ledere, akademikere og ansatte innen høyskoleyrker. Også i det rene minoritetsutvalget (modell 3) finner vi en signifikant forskjell mellom de største og de minste arbeidsplassene, og mellom ansatte innen renhold og hjelpearbeid på den ene siden og ledere/akademikere på den andre. 
TABELL 3. Overgang fra lønnet arbeid $i 2009$ til å stå uten lønnet arbeid $i 2012$. Kvinner 25-54 år. Bincer, logistisk regresjon. Odds rater

\begin{tabular}{|c|c|c|}
\hline & Modell 2 & $\begin{array}{c}\text { Modell } 3 \\
\text { (kun innvandrere) }\end{array}$ \\
\hline & $\operatorname{Exp}(B)$ & $\operatorname{Exp}(B)$ \\
\hline \multicolumn{3}{|l|}{ HUMAN KAPITAL } \\
\hline Irak & 3,247 & 2,079 \\
\hline Iran & 2,016 & 1,482 \\
\hline Pakistan & 2,529 & 1,986 \\
\hline Somalia & 2,282 & 1,906 \\
\hline Vietnam & 1,414 & Ref. \\
\hline \multicolumn{3}{|l|}{ Utdanning (ref: Lav/ingen utdanning) } \\
\hline Middels & ,650 & ,838 \\
\hline Нøу & ,567 & ,667 \\
\hline Uoppgitt & 1,274 & 1,114 \\
\hline Alder & ,898 & ,953 \\
\hline Alder kvadrert & 1,001 & 1,001 \\
\hline Botid & .. & ,942 \\
\hline Botid kvadrert & .. & 1,001 \\
\hline \multicolumn{3}{|l|}{ FAMILIESITUASJON } \\
\hline \multicolumn{3}{|l|}{ Sivilstatus (ref: ugift) } \\
\hline Gift/partner & ,898 & ,813 \\
\hline Skilt/separert/enke & 1,339 & ,946 \\
\hline \multicolumn{3}{|l|}{ Yngste barns alder (ref: 0-5 år) } \\
\hline 6-11 år & ,859 & ,673 \\
\hline 12 år + & ,902 & ,784 \\
\hline Ingen barn & 1,301 & ,936 \\
\hline Giftet seg mellom 2009 og 2012 & 1,201 & 1,026 \\
\hline Skilt seg mellom 2009 og 2012 & 1,370 & 1,257 \\
\hline Fått barn mellom 2009 og 2012 & 1,426 & 2,016 \\
\hline \multicolumn{3}{|l|}{ ARBEIDSLIV } \\
\hline \multicolumn{3}{|l|}{ Antall ansatte (ref: 1-19) } \\
\hline 20-49 & ,878 & ,862 \\
\hline $50-99$ & ,817 & ,788 \\
\hline $100+$ & ,807 & ,799 \\
\hline \multicolumn{3}{|l|}{ Yrkeskategori (ref: Adm. ledere, politikere, ak.yrker $(1,2)$} \\
\hline Yrker m/kortere høysk. el. univ.utd, tekn. (3) & 1,000 & ,746 \\
\hline Kontor- \& kundeserviceyrker, transport- og maskinoperatører $(4,8)$ & 1,156 & 1,266 \\
\hline Pleie- og omsorgspersonale (5) & ,990 & ,895 \\
\hline Salgs-, service- \& øvrige omsorgsyrker $(5,6,7,0)$ & 1,280 & 1,489 \\
\hline Yrker u/krav til utdanning, bl.a. renhold (9) & 1,482 & 1,347 \\
\hline \multicolumn{3}{|l|}{ Arbeidstid i 2009 (ref: kort deltid) } \\
\hline Lang deltid & ,522 & ,691 \\
\hline Heltid & ,399 &, 577 \\
\hline Konstantledd & 7,047 & 1,897 \\
\hline Nagelkerke R2 & ,084 &, 136 \\
\hline
\end{tabular}

Note: Odds-rater på over 1 viser en positiv sammenheng, under 1 negativ. Alle uthevde sammenhenger er signifikante på minst 5 prosents nivå. 


\section{DELTID - ET SPRINGBRETT?}

Vi har sett at deltid kan representere en løsere tilknytning til arbeidslivet enn heltid i den forstand at kvinner i deltidsstilling i større grad går ut av lønnet arbeid. Samtidig kan deltid også etterfølges av heltidsarbeid og en mer omfattende integrering i arbeidslivet. Figur 3 viser henholdsvis stabilitet og endring i arbeidstid blant kvinner som var ansatt i deltidsstillinger i 2009 og fortsatt hadde lønnet arbeid i 2012. Mellom 60 og 70 prosent av de kvinnene som arbeidet deltid $i$ 2009 hadde fortsatt en deltidsstilling tre år etter - de fleste i samme deltidsbrøk. Relativt få - under 10 prosent i alle landgrupper - reduserte arbeidstiden fra lang til kort deltid.

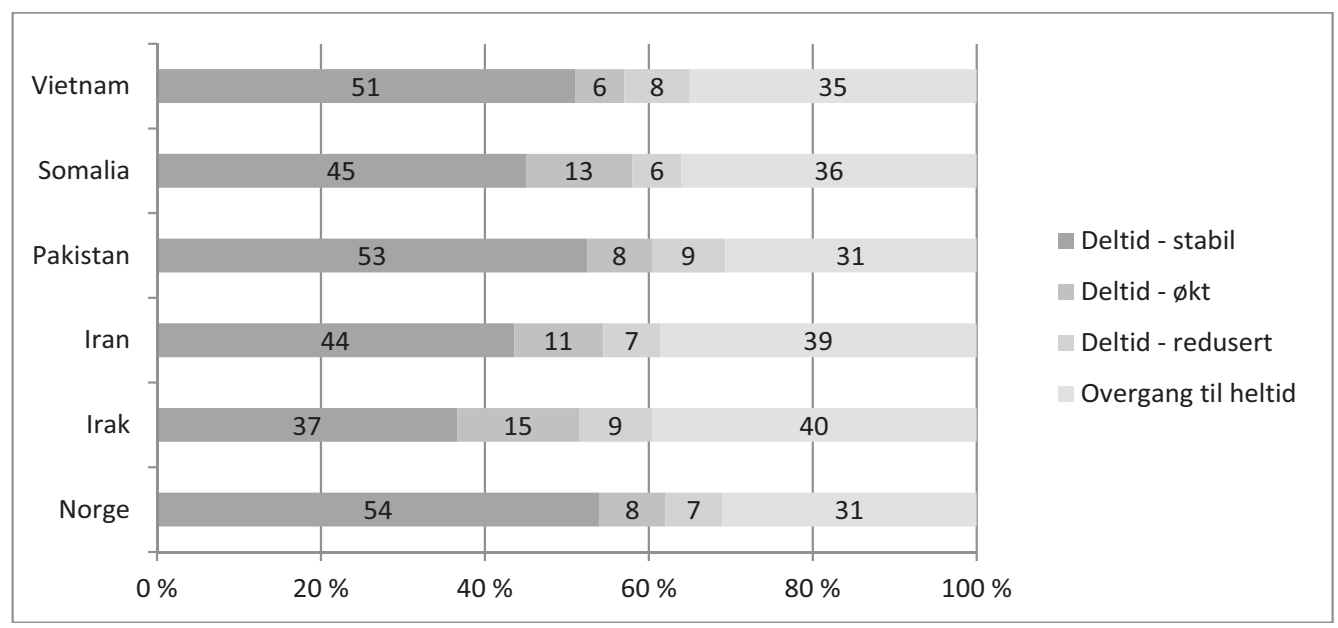

* Figuren omfatter kvinner som hadde lønnet arbeid både i november 2009 og i november 2012. FIGUR 3. Arbeidstid i 2012 blant kvinner ansatt $i$ deltidsstilling $i$ 2009, etter landbakgrunn*

De vi er mest opptatt av her, er likevel kvinner som i løpet av perioden gikk fra en deltids- til en heltidsstilling. Dette gjaldt 31 prosent av kvinnene fra Norge og Pakistan, og mellom 35 og 40 prosent av kvinnene fra de øvrige landgruppene. Tabell 4 tar utgangspunkt $i$ alle kvinner som var i lønnet arbeid både i 2009 og i 2012 og viser sannsynligheten for å ha økt arbeidstiden fra del- til heltid. I modell 4 ser vi at kvinner fra Irak, Iran, Somalia og Vietnam har høyere sannsynlighet for å øke arbeidstiden enn norske kvinner, også etter at vi har tatt hensyn til utdanning og familiestatus samt trekk ved arbeidsplassen og ansettelsesforholdet. Blant kvinner fra Pakistan er det ingen 
signifikant forskjell fra norske kvinner. Våre resultater er dermed langt på vei i tråd med funn fra den norske EU-SILC-surveyen (20032009) som tydet på at kvinner med bakgrunn fra ikke-vestlige land hadde høyere sannsynlighet for å gå fra del- til heltidsstillinger enn norske kvinner (Kitterød et al. 2013:162). Dette kan, som forfatterne av denne studien foreslo, tyde på at deltidsarbeid fungerer som en bro over til heltidsarbeid, og at deltid i mindre grad er frivillig blant innvandrere enn i den norske befolkningen. Samtidig modereres bildet av at deltid representerer et skritt på vei mot heltid for innvandrede kvinner av at bevegelsen fra deltid og ut av arbeidslivet er langt mer omfattende.

Kvinner med høy utdanning, både innvandrede og norske, har som forventet høyere sannsynlighet for å øke arbeidstiden enn kvinner med lavere utdanning (modell 4, 5 og 6). Vi finner ingen indikasjoner på at denne sammenhengen er verken sterkere eller svakere blant innvandrede enn blant norske kvinner (samspillsanalyser, ikke vist). Botid i Norge (modell 5 og 6) har heller ingen (målbar) effekt på sannsynligheten for å gå fra deltids- til heltidsstilling. ${ }^{10}$ Kvinner med små barn er mindre tilbøyelige til å øke arbeidstiden enn kvinner med eldre barn/uten barn. Dette gjelder både blant norske og innvandrede kvinner. For å undersøke om omsorgsoppgaver (barn under seks år i 2009) har ulik betydning for kvinner med ulik landbakgrunn, gjennomførte vi også samspillanalyser (online appendiks). De indikerer at omsorgsoppgaver reduserer sannsynligheten for å øke arbeidstiden blant somaliske kvinner i noe større grad enn blant norske kvinner. Vi finner ikke noe tilsvarende samspill i de øvrige landgruppene.

Våre resultater er langt på vei i tråd med tidligere forskning som har vist at det kan være vanskelig å bryte med den «typiske» arbeidsorganiseringen i en bransje. Kvinner som jobber i typiske deltidsyrker har lavere sannsynlighet for å øke arbeidstiden sin enn kvinner i yrker som er mindre preget av deltidsarbeid. I tillegg spiller det en rolle hvor mange timer den avtalte arbeidstiden var i 2009: kvinner i korte deltidsstillinger har lavere sannsynlighet for overgang til heltid enn kvinner med høyere stillingsbrøk. Vi finner også at mobilitet - fra én stilling til en annen - øker sannsynligheten for å gå fra deltid til heltid. Det ser ut til at den positive relasjonen mellom yrkesbytte og overgang til heltid er noe svakere blant irakiske kvinner enn blant 
norske (samspillsanalyse, online appendiks). Det er fristende å spørre om dette kan være et resultat av ulik posisjon på arbeidsmarkedet. For noen kan det å bytte stilling være en konsekvens av at det er vanskelig å finne - og beholde - arbeid, snarere enn en strategi for å øke arbeidstiden. Det kan imidlertid også hende at deltid er ønsket, og at målet med å bytte stilling er å få andre arbeidsoppgaver eller arbeidsforhold - ikke lengre arbeidstid. I de øvrige innvandrergruppene er det ikke noen signifikant forskjell på dette området sammenliknet med blant norske kvinner.

TABELL 4. Overgang fra deltid (2009) til heltid (2012). Kvinner 25-54 år. Bincer, logistisk regresjon. Odds ratio estimater

\begin{tabular}{|c|c|c|c|}
\hline & $\begin{array}{l}\text { Modell } 4 \\
\text { Exp (B) }\end{array}$ & $\begin{array}{l}\text { Modell } 5 \\
\text { Exp.(B) }\end{array}$ & $\begin{array}{l}\text { Modell 6* } \\
\text { Exp (B) }\end{array}$ \\
\hline \multicolumn{4}{|l|}{$\begin{array}{l}\text { HUMAN KAPITAL } \\
\text { Landbakgrunn (ref: Norge) }\end{array}$} \\
\hline Irak & 1,690 & ,916 & 1,211 \\
\hline Iran & 1,293 & ,903 & 1,063 \\
\hline Pakistan & 1,225 & ,721 & ,924 \\
\hline Somalia & 1,503 & ,759 & 1,096 \\
\hline Vietnam & 1,318 & Ref. & Ref. \\
\hline \multicolumn{4}{|l|}{ Utdanning (Lav/ingen utdanning ref) } \\
\hline Middels & 1,148 & 1,012 & ,969 \\
\hline Нøу & 1,761 & 1,947 & 1,547 \\
\hline Uoppgitt & 1,248 & 895 & 1,031 \\
\hline Alder & ,997 & 1,036 & 1,071 \\
\hline Alder kvadrert & ,999 & 999 & ,999 \\
\hline Botid & .. & 1,027 & 1,017 \\
\hline Botid kvadrert & .. & ,999 & ,999 \\
\hline \multicolumn{4}{|l|}{ FAMILIESITUASJON } \\
\hline \multicolumn{4}{|l|}{ Sivilstatus (Ref: ugift) } \\
\hline Gift/partner & ,799 & 1,098 & ,983 \\
\hline Skilt/separert/enke & 1,101 & 1,009 & ,997 \\
\hline \multicolumn{4}{|l|}{ Yngste barns alder (ref: t.o.m. 5 år) } \\
\hline 6-11 år & 1,217 & 1,422 & 1,231 \\
\hline 12 år + & 1,273 & 1,156 & 1,161 \\
\hline Ingen barn & 1,168 & 1,370 & 1,322 \\
\hline Giftet seg mellom 2009 og 2012 & ,988 & 1,331 & 1,646 \\
\hline Blitt skilt mellom 2009 og 2012 & 1,573 & ,697 & ,696 \\
\hline Fått barn mellom 2009 og 2012 & ,622 & ,535 & 898 \\
\hline
\end{tabular}


TABELL 4. Overgang fra deltid (2009) til heltid (2012). Kvinner 25-54 år. Bincer, logistisk regresjon. Odds ratio estimater (forts.)

\begin{tabular}{|c|c|c|c|}
\hline & $\begin{array}{l}\text { Modell } 4 \\
\text { Exp (B) }\end{array}$ & $\begin{array}{l}\text { Modell } 5 \\
\text { Exp.(B) }\end{array}$ & $\begin{array}{l}\text { Modell 6* } \\
\text { Exp (B) }\end{array}$ \\
\hline \multicolumn{4}{|l|}{ ARBEIDSLIV } \\
\hline \multicolumn{4}{|l|}{ Antall ansatte (ref: 1-19) } \\
\hline $20-49$ & 1,216 & 1,112 & 1,185 \\
\hline $50-99$ & 1,118 & 1,071 & 1,063 \\
\hline $100+$ & 1,058 & 1,360 & 1,518 \\
\hline \multicolumn{4}{|l|}{ Yrkeskategori (ref: Adm. Ledere, politikere, akad.yrker $(1,2)$} \\
\hline Yrker m/kortere høysk. el. univ.utd, tekn.(3) & ,737 & .. & 1,213 \\
\hline Kontor- \& kundeserv, transport- og maskinoperatører $(4,8)$ & ,859 & .. & 1,443 \\
\hline Pleie- og omsorgspersonale (5) &, 569 & .. & 1,026 \\
\hline Salgs-, service- \& øvrige omsorgsyrker $(5,6,7,0)$ & 861 & .. & 1,877 \\
\hline Yrker u/krav til utdanning, bl.a. renhold (9) &, 590 & .. & 1,370 \\
\hline Byttet yrke mellom 2009 og 2012 & 3,152 & .. & 2,663 \\
\hline Kort deltid (ref: lang deltid) &, 563 & ,732 & ,735 \\
\hline Constant & 1,278 & 221 & ,104 \\
\hline Nagelkerke R2 & 175 & ,070 & ,135 \\
\hline
\end{tabular}

*I modell 6 reduseres N fra 2579 til 1526 når yrkeskategori og endring av yrkeskategori inkluderes.

\section{DISKUSJON OG KONKLUSJON}

I foreliggende forskning er det gjentatte ganger vist at innvandrede kvinner med bakgrunn fra Asia og Afrika har lavere sysselsetting enn norske kvinner uten innvandringsbakgrunn. Forskningen har i mindre grad oppholdt seg ved hva som preger yrkesdeltakelsen blant de som er - eller har vært - en del av norsk arbeidsliv. I denne artikkelen tar vi utgangspunkt i kvinner som har innvandret til Norge fra Irak, Iran, Pakistan, Somalia og Vietnam og som alle var i lønnet arbeid i 2009. Ved hjelp av et omfattende registerpanel har vi fulgt kvinnenes deltakelse i arbeidslivet fram til november 2012, med særlig vekt på mobilitet fra deltid til heltid og stabilitet i arbeidstilknytning.

Sammenliknet med de øvrige nordiske landene har Norge både høyest andel deltidsansatte og høyest andel som jobber kort deltid. Men deltidsarbeiderne i Norge har også størst mobilitet, både når det gjelder å øke og redusere arbeidstiden (Nergaard 2010:173). Blant kvinner fra Irak, Iran, Somalia og Vietnam er tilbøyeligheten til å øke 
arbeidstiden signifikant høyere enn blant de norske, også etter at vi har tatt hensyn til egenskaper ved kvinnene, deres familier, arbeidstiden og den delen av arbeidsmarkedet de befinner seg i. Resultatene tilsier at deltidsarbeid kan representere en «bro» inn i en mer omfattende tilknytning til norsk arbeidsliv. Det kan også indikere at deltidsarbeid i mindre grad er en frivillig arbeidstidstilpasning enn blant norske kvinner. En slik fortolkning støttes både av at andelen som går fra hel- til deltidsstillinger er lav (Kitterød et al. 2013; egne analyser ikke vist), og av AKU-data som viser at forekomsten av ufrivillig deltid er høyere blant innvandrere enn i befolkningen for øvrig (Bø 2013). Innvandrede kvinners overrepresentasjon i typiske deltidsbransjer reduserer trolig også muligheten deres for å øke arbeidstiden sammenliknet med norske kvinner. Denne antagelsen styrkes av at kvinner som har byttet stilling har større relativ sannsynlighet for å øke arbeidstiden enn kvinner som har beholdt samme stilling. Dette er likevel bare en del av historien.

Innvandrede kvinner har også en langt mindre stabil tilknytning til arbeidslivet enn norske kvinner uten innvandringsbakgrunn. Blant somaliere og irakere forsvant fire av ti ut av lønnet arbeid mellom 2009 og 2012, mot en av ti norske kvinner, to av ti vietnamesiske og om lag tre av ti pakistanske kvinner. Jo kortere arbeidstiden var i 2009, desto høyere var den relative risikoen for ikke å ha jobb i 2012.

Ut fra teorier om landspesifikk human kapital er det i tråd med forventningene at innvandrere har høyere risiko for å miste jobben enn befolkningen ellers. Mange er nye i Norge, og vil bruke tid på å skaffe seg et nettverk og på å etablere eller formalisere de ferdighetene som kreves for å etablere en robust tilknytning til arbeidsmarkedet. Dette kan handle om å bestå norskprøver, få godkjent utenlandsk utdanning eller å gjennomføre nye kvalifiserings- og utdanningsløp. At lang botid reduserer risikoen for å gå ut av lønnet arbeid, tyder på at noe av ulempene knyttet til å være ny i Norge blir mindre over tid.

Variasjon i forekomsten av kjønnstradisjonelle holdninger trekkes også ofte fram som en mulig forklaring på forskjeller i yrkesdeltakelse mellom innvandrede og innfødte kvinner (Holdsworth \& Dale 1997; Khoudja \& Fleischmann 2015). Khoudja og Fleischmann (2015) finner for eksempel at ulike holdninger til kjønnsroller bidrar til å forklare forskjeller i yrkesdeltakelse mellom kvinner fra Nederland og 
fire ulike grupper av innvandrede kvinner. Også i norske studier framstår innvandrere $\mathrm{i}$ all hovedsak som mer restriktive til mødres yrkesaktivitet enn nordmenn, men det er samtidig tydelige variasjoner mellom landgrupper (Kavli \& Nadim 2009). Innvandrere fra Pakistan og Somalia er mer negative til mødres yrkesdeltakelse enn innvandrere fra Iran og Vietnam. Det er også et visst sammenfall mellom landgrupper der fertiliteten er høy og holdningene til kvinners yrkesdeltakelse er restriktive. Dette er relevant fordi konsekvensene av kjønnstradisjonelle holdninger kan forsterkes i familier med mange barn. Mange pauser i yrkeskarrieren grunnet lønnet og ulønnet permisjon kan gjøre det vanskeligere å få fotfeste i arbeidsmarkedet og å holde på både deltids- og heltidsjobber.

Våre analyser viser at kvinner fra Pakistan har en noe høyere risiko for å gå ut av lønnet arbeid i småbarnsfasen enn norske kvinner. Ut over dette finner vi få indikasjoner på at omsorg for små barn i større grad sender innvandrede enn norske kvinner ut av arbeidslivet. Her skal det nevnes at når materialet brytes ned etter landgruppe, blir antallet personer såpass lavt at eventuelle sammenhenger kan bli vanskelige å påvise. Med andre ord - det kan være en sammenheng selv om vi ikke finner den. På den andre siden er det slett ikke sikkert at generelt restriktive holdninger til mødres yrkesdeltakelse i er like relevant $\mathrm{i}$ en studie som kun har med kvinner som i utgangspunktet har orientert seg mot lønnet arbeid.

Egenskaper ved arbeidsmarkedet og økonomiens rolle for innvandrede kvinners tilnærming til lønnsarbeid har ifølge Pinto og Coltrane (2009) ofte havnet i skyggen av kulturforklaringer. De argumenterer for at når lønningene i de delene av arbeidsmarkedet som er åpne for innvandrere er lave, har familiene behov for to (fulle) inntekter. Muligheten til å velge om kvinner skal jobbe eller ikke, og eventuelt hvor mye, påvirkes dermed av strukturene i arbeidsmarkedet. Familiens økonomiske behov kan overstyre eventuelle kjønnstradisjonelle holdninger. Også i Norge er innvandrere overrepresentert i de minst regulerte og lavest lønnede delene av arbeidslivet. Selv om velferdsstatens beskyttelse er langt mer omfattende enn i USA, tilsier dette at det er nødvendig å dreie søkelyset noe vekk fra arbeidstakernes holdninger til kvinners yrkesaktivitet, og over mot hva som kjennetegner de delene av arbeidslivet kvinnene befinner seg i. 
Selv etter kontroll for både human kapital, familiesituasjon og type arbeidsplass, er avgangsraten blant innvandrede kvinner høyere enn blant norske kvinner uten innvandringsbakgrunn. Helse kan trolig bidra til å forklare noe av denne variasjonen. Både deltakelse i arbeidslivet og mobilitet $i$ arbeidstid (Kitterød et al. 2013:162) påvirkes av arbeidstakernes helsesituasjon. Vi mangler informasjon om helse i vårt materiale, men blant innvandrere fra landene i vår studie tyder mottaket av helserelaterte ytelser (Dahl, Hansen og Olsen 2010; Bratsberg, Raaum \& Røed 2016) og egenrapportert helse (Blom 2008) på at forekomsten av helseplager er større enn i befolkningen sett under ett. Systematiske forskjeller i helse kan dermed være noe av forklaringen på at innvandrede kvinner i større grad forsvinner ut av arbeidsmarkedet enn norske kvinner.

Et stort antall studier har også vist at diskriminering skaper utfordringer for ikke-vestlige innvandrere i vertslandenes arbeidsmarkeder (for en gjennomgang, se Midtbøen 2015). Diskrimineringen kan dreie seg om at ellers identiske arbeidssøkere vurderes ulikt i ansettelsesprosesser, men også om arbeidsgiveres vurderinger av de som allerede er ansatt og hvem som først må gå under nedbemanninger. Diskriminering kan være en del av forklaringen på at innvandrede kvinner i så mye større grad enn norske kvinner går ut av arbeidslivet. Det er likevel vanskelig å avgjøre hvor mye av ulikheten i utfall som eventuelt skyldes diskriminering, og om dette er mer eller mindre viktig enn andre forklaringer.

Selv en lav deltidsstilling kan ha en viktig funksjon både økonomisk og sosialt for kvinner som ellers ville stått helt utenfor arbeidslivet. Våre analyser tyder dessuten på at en deltidsjobb kan lede til en mer omfattende arbeidsdeltakelse på sikt. I et integreringsperspektiv er det likevel bekymringsfullt at yrkesdeltakelsen for så mange innvandrede kvinner framstår som ustabil og usikker. Etter vårt syn er det derfor behov for mer kunnskap om hvordan samspillet mellom kvinnenes bakgrunn og utgangspunkt, velferdsstatens institusjoner og arbeidslivets organisering påvirker ulike grupper av innvandrede kvinner og deres økonomiske integrering. 


\section{OM ARTIKKELEN}

Arbeidet er finansiert med bidrag fra Barne-, likestillings- og inkluderingsdepartementet, Samfunnspolitisk avdeling i LO og NFR-prosjekt (237031), «Deltidskarrierer i Norge - normaliseringens endepunkt? Kvinners valg av arbeidstid i et longitudinelt perspektiv». Registerdata er gjort tilgjengelig gjennom prosjektet «Work Life Challenges» (202647/S20) - takk til prosjektleder Harald Dale-Olsen. Takk også til Anne Lise Ellingsæter, Axel West Pedersen og Anne Britt Djuve for verdifulle kommentarer og til Kristine Nergaard for svært god hjelp med å tilrettelegge data.

\section{Noter}

1 Sysselsetting blant innvandrere, registerbasert, 2014, 4. kvartal, tabell 2. Publisert: 18.06.2015. Statistisk sentralbyrå.

2 I teksten veksler vi for enkelhets skyld mellom «norske kvinner uten innvandringsbakgrunn» og «norske kvinner».

3 Informasjon om innvandreres utdanning før ankomst til Norge er basert på Statistisk sentralbyrås levekårsundersøkelse i innvandrerbefolkningen fra 2005/2006. I tillegg brukes data fra utdanningsregisteret over utdanning som er gjennomført i Norge.

4 Aldersavgrensningen er gjort for å utelate unge i livsfaser der lønnet arbeid i mindre grad er hovedaktivitet, og fordi antallet yrkesaktive kvinner over 54 år er lavt blant innvandrede kvinner i de utvalgte innvandrergruppene.

5 Alternative familievariabler ble testet, men ga i all hovedsak tilsvarende resultater. Disse var: antall barn under 18 år (0,1-2, $3+)$ og antall barn under 7 år.

6 Kvinner i omsorgspermisjon skal i hovedsak være registrert med avtalt arbeidstid på permisjonstidspunktet.

7 Analysene er også gjennomført kun for kvinner (25-54 år) som har barn under 18 år (ikke vist). De viser at mødre fra Irak, Iran og Vietnam som er i lønnet arbeid er mindre tilbøyelige enn etnisk norske mødre til å arbeide deltid. Mødre fra Somalia er mer tilbøyelige til å arbeide deltid, mens det blant mødre fra Pakistan ikke er noen målbar forskjell i sannsynligheten for å arbeide deltid sammenliknet med den blant norske mødre.

8 At skilsmisse øker sannsynligheten for å gå ut av arbeidsmarkedet, er i utgangspunktet overraskende siden ressursene normalt blir knappere når en husholdning deles i to og dermed øker behovet for at kvinnen forblir i lønnet arbeid. En mulig forklaring kan være at (økte) omsorgsoppgaver kan gjøre det vanskeligere å stå i arbeid for enslige mødre, spesielt i den første tiden etter skilsmissen som er det vi måler her. Ulike støtteordninger rettet mot enslige mødre kan trekke i samme retning.

9 Alternative operasjonaliseringer av samspillsleddet er testet: (land*barn under tre år i 2009) og (land"barn under tolv år i 2009). Samspillsleddene for pakistanske 
kvinner er signifikante på tvers av operasjonaliseringene og framstår dermed som robuste. For irakiske kvinner er resultatene mer ustabile.

10 Følgende alternative operasjonaliseringer av botid ble testet: 1) 0-5 år, 6-10 år, 11-15 år og 16 år +, 2) Over eller under 10 år, og 3) over eller under 15 år. I tillegg ble det gjort separate analyser i hver landgruppe, med botid som kontinuerlig og som kategoriserte variabler.

\section{Referanser}

Abrahamsen, B. (2009). Forskjeller i kvinners arbeidstid - et spørsmål om preferanser. Sosiologisk Tidsskrift, 17(4), 311-332.

Adsera, A. \& Chiswick, B. R. (2007). Are there gender differences in immigrant labor market outcomes across European countries? Journal of Population Economics, 20(3), 495-526. DOI: http://dx.doi.org/10.1007/s00148-006-0082-y.

Anxo, D., Fagan, C., Smith, M., Letablier, M.-T. \& Perraudin, C. (2007). Parental Leave in European Companies. Establishment Survey on Working Time 20042005. Luxembourg: European Foundation for the Improvement of Living and Working Conditions.

Atkinson, J. (1984). Manpower strategies for flexible organizations. Personnel Management, 16, 28-31.

Becker, G. (1964). Human Capital. A Theoretical and Empirical Analysis, with Special Reference to Education. 3. utg. Chicago: University of Chicago Press.

Berglund, T. E. et.al. (2010). Labour Market Mobility in Nordic Welfare States. TemaNord 2010:515. Copenhagen: Nordic Council of Ministers. DOI: http:// dx.doi.org/10.6027/tn2010-515.

Bevelander, P. \& Groeneveld, S. M. (2006). Patterns of transition: Female native Dutch and ethnic minority employment patterns in the Dutch labour market, 1991 and 2002. Journal of Ethnic and Migration Studies, 32(5), 785-807. DOI: http://dx.doi.org/10.1080/13691830600704198.

Blom, S. (2008). Innvandreres helse 2005-2006. Oslo/Kongsvinger: Statistisk sentralbyrå. URL: https://www.ssb.no/a/publikasjoner/pdf/rapp_200835/rapp_200835.pdf

Borjas, G. J. (1995). Assimilation and changes in cohort quality revisited: What happened to immigrant earnings during the 1980s? Journal of Labour Economics, 13, 201-245. DOI: http://dx.doi.org/10.3386/w4866.

Bosch, G. (2006). Working time and the standard employment relationship. I Boulin, J. Y., Lallement, M., Messenger, J. C. \& Michon, F. (red.), Decent Working Time: New Trends, New Issues (41-64). Geneva: Internat. Labour Office.

Bratsberg, B., Raaum, O. \& Røed, K. (2012). Educating children of immigrants: Closing the gap in Norwegian schools. Nordic Economic Policy Review, 3, 211-251.

Bratsberg, B., Raaum, O. \& Røed, K. (2016). Immigrants, labour market performance and social insurance. Economic Journal, 124, F644-683. DOI: http:// dx.doi.org/10.1111/ecoj.12182.

Bø, T. P. (2013). Innvandrere på arbeidsmarkedet. Data fra Arbeidskraftundersøkelsen. Rapporter 49:2013. Oslo: Statistisk sentralbyrå.

Böheim, R. \& Taylor, M. P. (2004). Actual and preferred working hours. British Journal of Industrial Relations, 42(1), 149-166. DOI: http://dx.doi.org/10.1111/ j.1467-8543.2004.00308.x.

Chiswick, B. R., Lee, L. Y. \& Miller, P. W. (2005). Immigrant earnings: A longitudinal analysis. Review of Income and Wealth, International Association for Research in 
Income and Wealth, 51(4), 485-503. DOI: http://dx.doi.org/10.1111/j.14754991.2005.00165.x.

Chiswick, B. R. \& Miller, P. W. (2010). Occupational language requirements and the value of English in the United States labor market. Journal of Population Economics, 23(1), 353-372. DOI: http://dx.doi.org/10.1007/s00148-008-0230-7.

Crompton, R. \& Harris, F. (1998). Gender relations and employment: The impact of occupation. Work, Employment and Society, 12(2), 297-315.

DOI: http://dx.doi.org/10.1177/0950017098122005.

Dahl, S.-Å., Hansen, H.-T. \& Olsen, K. M. (2010). Sickness absence among immigrants in Norway, 1992-2003. Acta Sociologica, 53, 35-52. DOI: http://dx.doi.org/10.1177/0001699309357841.

Dale, A., Shaheen, N., Kalra, V. \& Fieldhouse, E. (2002). Routes into education and employment for young Pakistani and Bangladeshi Women in the UK. Ethnic and Racial Studies, 25(6), 942-968. DOI: http://dx.doi.org/10.1080/0141987022000009386.

Daugstad, G. (2008). Ekteskap over landegrensene. Ekteskap og transnasjonale familieetableringer i perioden 1990-2007. Rapporter 2008/41. Oslo/Kongsvinger: Statistisk sentralbyrå. URL: https://www.ssb.no/befolkning/artikler-og-publikasjoner/ ekteskap-over-landegrensene.

Drange, I. (2009). Sysselsatt eller tilsidesatt? Heltidstilpasning blant høyt utdannede minoritetskvinner. I Mastekaasa, A. \& Birkelund, G. E. (red.), Integrert? Innvandrere og barn av innvandrere i utdanning og arbeidsliv (163-178). Oslo: Abstrakt forlag.

Ellingsæter, A. L. (1989). Normalisering av deltidsarbeidet. En analyse av endring $i$ kvinners yrkesaktivitet og arbeidstid i 80-årene. Oslo: Statistisk sentralbyrå.

Ellingsæter, A. L. (1992). Part-Time Work in European Welfare States: Denmark, Germany, Norway and the United Kingdom compared. Oslo: Institute for Social Research, 92:10.

Ellingsæter, A. L. (2009). Vår tids moderne tider. Oslo: Universitetsforlaget.

Friedberg, R. M. (2000). You cant't take it with you? Immigrants' assimilation and the portability of human capital. Journal of Labor Economics, 18(2), 221-251. DOI: http://dx.doi.org/10.3386/w5837.

Hakim, C. (1991). Grateful slaves and self-made women: Fact and fantasy in women's work-orientations. European Sociological Review, 7(2), 101-21. DOI: http://dx.doi.org/10.1080/08164640220123407.

Hakim, C. (2006). Women, careers, and work-life preferences. British Journal of Guidance and Counselling, 34(3), 279-294.

DOI: http://dx.doi.org/10.1080/03069880600769118.

Halrynjo, S. \& Lyng, S.T. (2009). Preferences, constraints or schemas of devotion? Exploring Norwegian mothers' withdrawal from high-commitment careers. British Journal of Sociology, 60(2), 321-343. DOI: http://dx.doi.org/10.1111/j.14684446.2009.01233.x.

Hardoy, I. \& Schøne, P. (2008). Returns to pre-immigration education for non-western immigrants: why so low? Education Economics, 19(1), 1-25. DOI: http://dx.doi.org/10.1080/09645292.2010.511846.

Heath, A. \& Demireva, N. (2013). Has multiculturalism failed in Britain? Ethnic and Racial Studies, 37(1), 161-180.

DOI: http://dx.doi.org/10.1080/01419870.2013.808754. 
Henriksen, K. (2010). Kjønnsforskjeller og levekår blant innvandrere fra 10 land. Rapport 6/2010. Oslo/Kongsvinger: Statistisk sentralbyrå.

URL: https://www.ssb.no/sosiale-forhold-og-kriminalitet/artikler-og-publikasjoner/levekar-og-kjonnsforskjeller-blant-innvandrere-fra-ti-land.

Holdsworth, C. \& Dale, A. (1997). Ethnic differences in women's employment. Work, Employment and Society, 11(3), 435-457.

DOI: http://dx.doi.org/10.1177/0950017097113003.

Holdsworth, C. \& Dale, A. (1998). Why don't minority ethnic women in Britain work part-time? I O'Reilly, J. \& Fagan, C., Part-Time Prospects. An International Comparison of Part-Time Work in Europa, North-America and the Pacific Rim (77-198). London/New York: Routledge.

DOI: http://dx.doi.org/10.4324/9780203276105.

Horrell, S. \& J.Rubery (1991). Gender and working time: An analysis of employers' working-time policies. Cambridge Journal of Economics, 15, 373-391.

Kavli, H. C. (2004). Familiepolitiske dilemmaer i det fleretniske samfunnet. I Ellingsæter, A. L. \& Leira, A. (red.), Velferdsstaten og familien. Utfordringer og dilemmaer (290-321). Oslo: Gyldendal Akademisk.

Kavli, H. C. (2015). Adapting to the dual earner family norm? The case of immigrants and immigrant descendants in Norway. Journal of Ethnic and Migration Studies, 41(5), 535-556. DOI: http://dx.doi.org/10.1080/1369183x.2014.975190.

Kavli, H. C. \& Nadim, M. (2009). Familiepraksis og likestilling $i$ innvandrede familier. Fafo-rapport 2009:39. Oslo: Fafo.

Khoudja, Y. \& Fleischmann, F. (2015). Ethnic differences in female labour force participation in the Netherlands - Adding gender role attitudes and religiosity to the explanation. European Sociological Review, 31(1), 91-102.

DOI: http://dx.doi.org/10.1093/esr/jcu084.

Kitterød, R. H., Rønsen, M. \& Seierstad, A. (2013). Mobilizing female labour market reserves: What promotes women's transitions between part-time and full-time work? Acta Sociologica, 56(2), 155-171.

DOI: http://dx.doi.org/10.1177/0001699313479954.

Kjelstad, R. (2006). Hvorfor deltid? Tidsskrift for samfunnsforskning, 47(4), 513544.

Kjeldstad, R. \& Nymoen, E. H. (2004). Kvinner og menn i deltidsarbeid. Fordeling og forklaringer. Rapport 29/2004. Oslo/Kongsvinger: Statistisk sentralbyrå.

Kogan, I. (2011). New immigrants - Old disadvantage patterns? Labour market integration of recent immigrants into Germany. International Migration, 49(1), 91117. DOI: http://dx.doi.org/10.1111/j.1468-2435.2010.00609.x.

Longhi, A., Nicoletti, C. \& Platt, L. (2013). Explained and unexplained wage gaps across the main ethno-religious groups in Great Britain. Oxford Economic Papers, 65(2), 471-493. DOI: http://dx.doi.org/10.1093/oep/gps025.

Martinovic, B., van Tubergen, F. \& Maas, I. (2009). Dynamics of interethnic contact: A panel study of immigrants in the Netherlands. European Sociological Review, 25(3), 303-318. DOI: http://dx.doi.org/10.1093/esr/jen049.

Messenger, J. C. (2006). Towards decent working time. I Boulin, J.-Y., Lallement, M., Messenger, J. C. \& Michon, F. (red.), Decent Working Time. New Trends, New Issues. Geneva: International Labour Office.

Midtbøen, A. H. (2015). Etnisk diskriminering i arbeidsmarkedet. Tidsskrift for samfunnsforskning, 55(1), 3-30.

Nergaard, K. (2010). Mobility in and out of part-time work. I Berglund, T. E. (red.), Labour Market Mobility in Nordic Welfare States. TemaNord 2010:515. Copenhagen: Nordic Councils of Ministers. DOI: http://dx.doi.org/10.6027/tn2010-515. 
Nicolaisen, H. (2013). Løsninger på deltidsutfordringen - ingen «quick fix». Søkelys på arbeidslivet, 30(1-2), 151-157.

NOU (2012:15). Politikk for likestilling. Oslo: Barne-, likestillings- og inkluderingsdepartementet.

Nymoen, E. H. (2012). Part-time work and gender: Worker versus job explanations. International Labour Review, 151(1-2), 85-107. DOI: http://dx.doi.org/10.1111/ j.1564-913x.2012.00136.x.

Nätti, J. (1995). Part-time work in the Nordic countries: A trap for women? Labour, 9(2), 343-357. DOI: http://dx.doi.org/10.1111/j.1467-9914.1995.tb00256.x.

O'Reilly, J. \& Fagan, C. (red.) (1998). Part-Time Prospects. An International Comparison of Part-Time Work in Europe, North America and the Pacific Rim. London: Routledge. DOI: http://dx.doi.org/10.4324/9780203276105.

O'Reilly, J. \& Bothfeld, S. (2002). What happens after working part-time? Integration, maintenance or exclusionary transitions in Britain and Western Germany. Journal of Economics, 26, 409-439. DOI: http://dx.doi.org/10.1093/cje/26.4.409.

Parrado, E. A. \& Flippen, C. A. (2005). Migration and gender among Mexican women. American Sociological Review, 70(4), 606-632. DOI: http://dx.doi.org/ 10.1177/000312240507000404.

Pinto, K. M. \& Coltrane, S. (2009). Divisions of labor in Mexican and Anglo families: Structure and culture. Sex Roles, 60, 482-495. DOI: http://dx.doi.org/10.1007/ s11199-008-9549-5.

Rubery, J., Ward, K. \& Grimshaw, D. (2006). Time, work and pay: Understanding the new relationships. I Boulin, J.-Y., Lallement, M., Messenger, J. C. \& Michon, F. (red.), Decent Working Time. New Trends, New Issues (123-146). Geneva: ILO.

Rubin, J. (red.) (2008). Migrant women in the European Labour Force. Current situations and future prospects. RAND Cooperation.

Thomlinson, J. (2006). Part-time occupational mobility in the service industries: regulation, work commitment and occupational closure. The Sociological Review, 54(1), 66-86. DOI: http://dx.doi.org/10.1111/j.1467-954x.2006.00602.x.

Tønnessen, M. (2014). Fruktbarhet og annen demografi hos innvandrere og deres barn $i$ Norge. Rapporter 2014/4. Oslo/Kongsvinger: Statistisk sentralbyrå. URL:

Yerkes, M. \& Visser, J. (2006). Women's preferences or delineated policies? The development of part-time work in the Netherlands, Germany and the United Kingdom. I Boulin, J.-Y., Lallement, M., Messenger, J. C. \& Michon, F. (red.), Decent Working Time. New Trends, New Issues. (235-261) Geneva: ILO. DOI: http://dx.doi.org/10.1590/s1415-65552008000300018. 

Artikkel 3 Facilitating user involvement in activation programmes: When Carers and Clerks meet Pawns and Queens 



\title{
Facilitating User Involvement in Activation Programmes: When Carers and Clerks Meet Pawns and Queens
}

\author{
ANNE BRITT DJUVE* and HANNE C. KAVLI** \\ * Fafo Institute for Labour and Social Research, Oslo, Norway \\ email: Anne.Britt.Djuve@fafo.no \\ **Fafo Institute for Labour and Social Research, Oslo, Norway \\ email: Hanne.Kavli@fafo.no
}

\begin{abstract}
User involvement has become an explicit goal within social service provision. Even so, the term remains ambiguous, and its implementation troublesome. Implementation theory lists a number of factors influencing bureaucratic behaviour; in this paper we investigate the 'human factor'. Our ambition is to provide a framework for analysis of user influence in activation programmes that includes the individual characteristics of both service users and service providers. Building on theoretical insights from the literature on activation and agency, we develop a framework that distinguishes between two ideal types of service users: Pawns and Queens, and two types of service providers: care-oriented Carers and rule-oriented Clerks. This framework is then applied to identify key challenges for the interaction between users and caseworkers in two challenging situations: when service users express little or no agency and when they express agency that is incompatible with the overall goals of the programme. We find that Carers show pronounced reluctance to overrule the choices made by service users even when they have conflicting views - and tend to postpone decisions when they interact with Pawns. Clerks tend to overrule the decisions of Queens when they have conflicting views, and to make decisions on behalf of Pawns. The analysis draws on data collected from 126 qualitative interviews with service providers and participants in the Norwegian Introductory Programme for immigrants and a survey of 320 caseworkers.
\end{abstract}

\section{Introduction}

User involvement and influence ${ }^{1}$ have become key elements in activation programmes, at least at the rhetorical level. The strong focus on designing services in cooperation with the user requires discretionary judgements by service providers. The welfare state's front line - here represented by the activation workers and their clients/users - is thereby turned into an important policy arena. Yet, the professional status of activation workers is indistinct (Sainsbury, 2008) and the literature is inconclusive on whether or not administration of activation measures is incompatible with professional (social) work (Van Berkel and Van der Aa, 2012). As we understand it, Lipsky's (1980) influential work on what he 
termed 'street-level bureaucrats' was based on the understanding that any public employee who translates public policy into individualised and discretionary decisions must be, to some extent, both administrator and professional. The mix between them will however differ according to both structural (Bloom et al., 2003; Jewell, 2007) and individual (Van Berkel, 2007; May and Winter, 2007) factors. The service users will on the other hand vary in their capacity and motivations to engage in discussions of the content and targets of the activation programme (Wright, 2012). Our ambition here is to study the consequences an administrative or a more social-work-oriented approach may have for the development of user involvement - also taking into account that service user characteristics matter. Our case study is the Norwegian Introductory Programme for refugees and immigrants (NIP), a compulsory, but remunerated, qualification programme with a high employee to participant ratio.

The introduction of the NIP represented a marked shift in Norwegian integration policy, away from unconditional social benefits and voluntary low-intensity language training, towards a compulsory full-day, year-round activation programme. As in other European countries, opponents of activation schemes voiced concerns that these schemes would undermine the social and cultural rights of immigrants (Djuve, 2011). Multiculturalism, understood as unconditional support of cultural rights, may however be difficult to combine with the high socio-political ambitions that characterise Nordic welfare states. Brochmann and Djuve (2013) argue that the Marshallian concept of social citizenship is a more adequate measure in evaluations of the legitimacy of NIP than multiculturalism alone, and that the risk of illegitimate cultural assimilation should be weighed up against gains in social citizenship. User influence has been argued to be a key element in distinguishing empowering programmes that develop social citizenship from intrusive programmes that diminish social citizenship (Djuve, 2010).

In this study of user influence, we are particularly interested in the responses of service providers in challenging situations when service users express little agency and situations when they express 'bad' agency (Wright, 2012); that is, preferences that are interpreted by service providers to be incompatible with policy goals or conditions. We suggest an analytical framework for the analysis that builds on insights from Julian Le Grand, Hartley Dean and Sharon Wright, and also on insights developed through our own fieldwork.

\section{Agency and actors in the activating state}

The activating state expects an engaged role for citizens, including marginalised citizens (Taylor-Gooby, 2005; Jensen and Pfau-Effinger, 2005). According to Arnstein (1969), citizen participation in decision making is essential for empowerment and democracy. The transition from passive recipient of services 
to active subject engaging with services is believed to be at the centre of user empowerment (Small, 2000). The active citizen is assumed to be self-responsible, and claimants of public transfers are expected to take an active role in the process of becoming self-reliant. This role entails more autonomy and choice than the traditionally passive client role: service users should be empowered and Queenlike, rather than passive and Pawn-like. The typical mode of practice within activation policy is individually tailored programmes aimed at enhancing users' employability (Minas, 2009) - an ideal which rests on user involvement and thus on service providers' ability to allow user autonomy as well as users' ability to make use of the autonomy they are granted. In other words, user involvement in the shaping of services not only presupposes agency on the part of the service users, but the ability and willingness of service providers to interact with this agency.

The interactive character of agency underscores the importance of taking into account characteristics of both service users and service providers in a study of user involvement. Le Grand (2003/06) discusses how policy makers' ideas about human agency and motivation shape public policy. According to Le Grand, perceptions of service users' agency are decisive for choice of policy measures. Are service users considered to be active, autonomous agents (Queens) or passive individuals (Pawns)? He defines agency as capacity to undertake action. Le Grand argues that allowing the service user freedom of choice between service providers is a way of granting autonomy to service users - to treat them as Queens. His examples are, however, chosen from the education and the health sector. In the case of activation and involuntary clients, choice between service providers may be tricky to implement (though not impossible, at least not in all cases), and activation may in itself be seen as a hindrance for both user involvement (Hasenfeld, 1999) and agency. On the other hand, activation measures may also be used for developmental (Marston et al., 2005) or empowerment (Djuve, 2011) reasons. In this context, successful user influence may be of particularly high importance for the ethical legitimacy of activation measures (Djuve, 2011). Also, other obstacles to agency such as lack of information, language problems and health issues may be more important for participants in activation programmes, in particular when they are newly arrived refugees.

Similarly, ideas about how service providers operate also shape public policy. Again, according to Le Grand, the important characteristic here is not so much their capacity to act, but their motivation for action: are they driven by care for others, or purely by self-interest? He categorises service providers either as selfish 'Knaves' or altruistic 'Knights'. The 'Knave' is defined as 'an individual whose principal concern is to further his or her self-interest' (Le Grand 2003/06: 25) while the 'Knight' is motivated by the prospect of helping others, even if there is no personal gain in sight. 
Le Grand's concepts of Knights, Knaves, Pawns and Queens were originally outlined to illustrate how service providers and service users are constructed in British public debate on social policy. We believe his model is also a good starting point for an analysis of the challenges inherent in service providers' facilitation of user influence. However, Le Grand's model has been criticised for being too simplistic. Dean (2003a: 702) argues that agency is not only rooted in what Le Grand describes as 'the capacity to act', but also in the 'actors understanding of their actions'. Agency, in this respect, entails different degrees of reflexivity: both having an idea about what you want, and how to get it. Wright (2012: 313) stresses that agency is 'context-specific, negotiated and differentiated in relation to identities'. Individuals who hold a sizeable capacity to act in some circumstances may be disempowered Pawns in others, and decision-making is complex. Contrary to Le Grand's assumption that service user agency is primarily individual and motivated by economic outcomes (ibid.: 312), Duncan and Edwards (1999) illustrated how care responsibilities and understandings of motherhood can be key to mothers' rationalities concerning the balance between care and employment.

\section{Service users}

Le Grand arrives at a model of motivation and agency in public policy where altruistic Knights and selfish Knaves in the social services meet service users who are either autonomous Queens or passive Pawns. Supposedly, the activating state favours autonomous Queens. On the other hand, activation programmes often entail sanctions that are intended to affect the behaviour of the participants and thereby potentially reduce individual autonomy. Sometimes service users behave in ways that are considered to be out of line with the programme, or pursue objectives that are deemed to be unrealistic or inapt. In the words of Wright (2012: 320): 'no conceptualization of agency is complete without incorporating the issues of bad intentions, actions and consequences'. However, what is to be deemed wise and/or morally good is highly disputable, and service users and providers may disagree both on whether a certain intention is (morally) good, and on the adequate means to pursue it. 'Bad' agency may refer to preferences for measures that service providers consider to be out of reach, outcomes that are deemed to be incompatible with programme policy, but also to what service providers think of as (morally) bad behaviour. Examples of the latter could in this setting be undocumented absence from the programme or attempts to sabotage the training. The ambition to modify 'bad' agency and curb 'irresponsible' freedoms (Dean, 2007) is an inherent paternalistic trait of activation policy.

In other words, an understanding of agency merely as 'capacity to act' may be inadequate when analysing user characteristics decisive for interaction with service providers. Also, it becomes evident that it is the characteristics of users, as 
Consensus

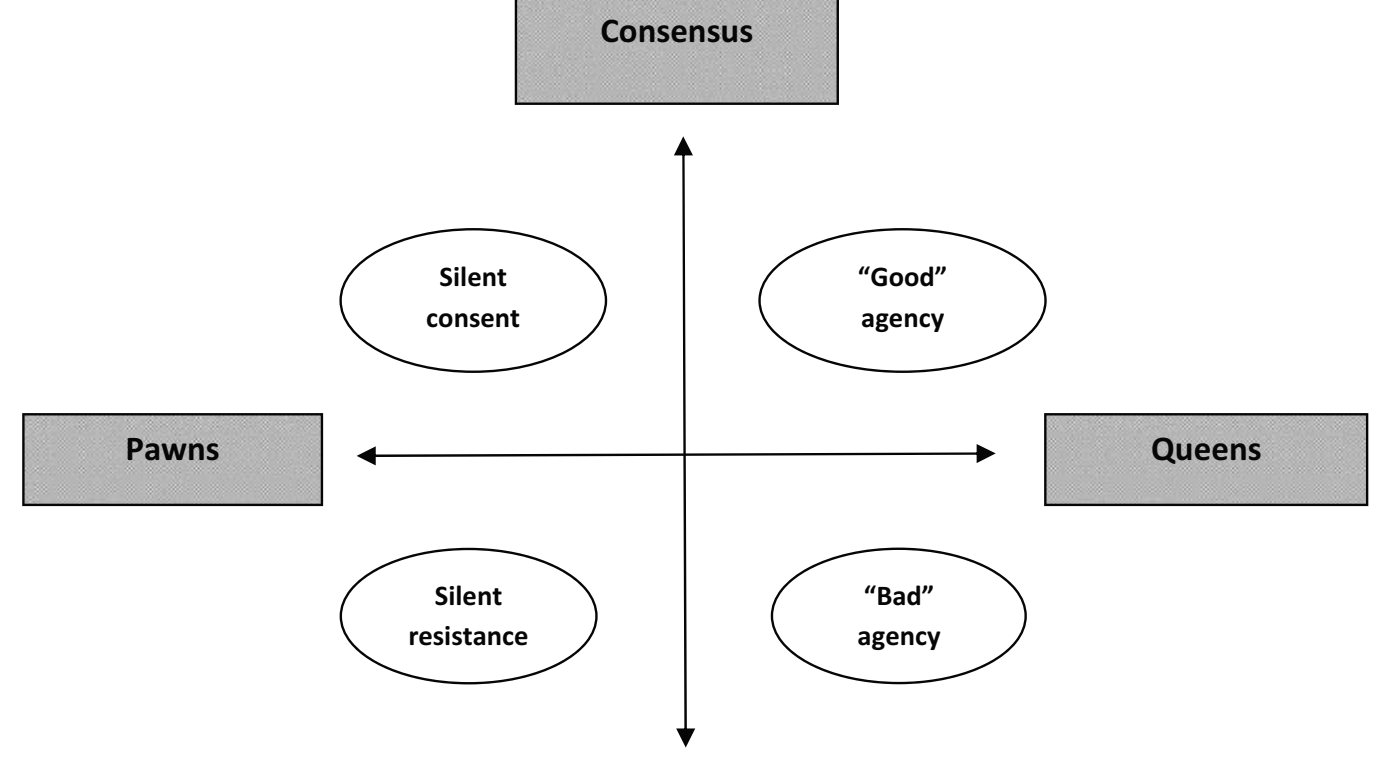

Disagreement

Figure 1. Service providers' perceptions of service user agency, by service user autonomy and level of consensus between service users and service providers

recognised and interpreted by service providers, that matters for user influence. The imbalance of power between users and providers of services is reflected in the fact that service providers not only tend to, but also get to, decide what is good and bad agency - and ultimately what is best for the participant. This process of categorisation depends on the level of consensus between users and providers: 'bad' agency is associated with a low level of consensus. On the other hand, both 'good' and 'bad' agency are also associated with some level of capacity to act, to communicate at least. Users who do not express their agency are difficult to place within the dimension of 'good' versus 'bad' agency. These users will typically be understood as silently consenting or silently resisting, though the difference may be hard to discern.

Figure 1 illustrates the four types of service user agency differentiated according to the level of consensus between the service user and the service provider, and the service users' capacity to act.

There is little doubt that 'good' agency is the most favourable condition for user involvement. On the 'Pawn' side of Figure 1, service providers struggle to make service users express their opinions. In the 'Bad' agency quadrant, the mission is rather to make them change their opinions. It is the encounters within these three problematic quadrants and the service providers' responses that will be at the centre of our empirical analysis: the silent either resistance or consent among Pawns, and the perceived bad agency among disagreeing Queens. 
TABLE 1. Care-oriented (Carers) and rule-oriented (Clerks) service provision

\begin{tabular}{ll}
\hline Care-oriented (Carers) & Rule-oriented (Clerks) \\
\hline - Flexible understanding of own tasks & • Clearly defined and rule-based \\
- Flexible and bargaining in user & understanding of own tasks \\
relations & - Strict and rule-bound in user relations \\
- Personal relation with the user & Professional distance from the user \\
- Micro-oriented on results & - Macro-oriented on results \\
\hline
\end{tabular}

Source: Djuve and Kavli (2006: 214).

\section{Service providers}

As already stated, the interactive character of agency underscores the importance of taking into account characteristics of both service users and service providers in studies of user involvement. How individual decision makers' characteristics can affect their discretionary judgements has been a recurring topic in the literature on implementation (Loyens and Maesschalk, 2010). The consensus-disagreement dimension in Figure 1 illustrates that the chararacteristics of service providers are also important: the categorisation of user agency into 'good' and 'bad' is likely to depend on the service providers' knowledge, ingenuity and ideas. Though the Weberian ideal may be that service providers implement policy uniformly, a long tradition of empirical and theoretical work points to the importance of caseworkers' skills, attitudes and personal beliefs (Van Meter and Van Horn, 1975; Lipsky, 1980; Eriksen, 2001; Le Grand, 2003/o6; Dean, 2003a; Terum, 2003; May and Winter, 2007). These attributes are, however, difficult to observe and identify. It may also be argued that it is not the beliefs of service providers that affect user influence, but their actions. Le Grand's contribution divided service providers according to their motivations, either as self-interested Knaves or altruistic Knights. We define the service providers according to their actions and, in doing so, put more emphasis on professional practices than on motivations and morality.

In an earlier study of service providers in the Norwegian refugee service (Djuve and Kavli, 2006), we identified two types of bureaucrats with different responses to the challenges of local service provision (see Table 1). 'The main loyalty of the rule-oriented bureaucrat is to 'the system', and in many ways resembles Weber's ideal bureaucrat (Weber 1920/1978). Regulations are to be observed and officially outlined goals are to be adopted. The rule-oriented bureaucrat maintains a professional distance and relies on rules and regulations to guide them in interactions with users. Since their loyalty lies with 'the system', they are inclined to focus on overall goal achievement (as specified in policy documents) rather than individual results. On the other side of the continuum, we find the care-oriented bureaucrat. Their loyalty lies primarily with the service 
user. The care-oriented bureaucrat emphasises the diversity of cases, and thereby the need to adapt the services to each individual participant. They enter into long-term, personal relations with users and are inclined to put most effort into the most complex cases.

In the following we will refer to the two categories of service providers as 'Clerks' and 'Carers'. Both may have morally good intentions (of doing a good job) and they may be more or less reflexive in the way they relate to the bureaucratic framework and the service users.

In the empirical section, we will investigate the encounters between Carers and Clerks, Pawns and Queens, with a particular focus on the troublesome situations that service providers perceive as 'bad agency' or 'no agency' among service users. As bureaucratic behaviour is shaped by the environment in which it unfolds, we will first give a short description of the Norwegian context of immigration and integration.

\section{The Norwegian context of immigration and integration}

Service provider discretion is performed within national and local contexts. These contexts are shaped by rules, regulations and finances concerning social policy, but also by immigration policy, sentiments towards immigrants and the composition of new arrivals of immigrants (Jordan et al., 2003). Bureaucrats' strategies to facilitate user influence can also take on different forms depending on the programme at hand and the resources available (Jewell, 2007). Our case study is the Norwegian Introductory Programme (NIP) for refugees and immigrants. The main ambition for this two-year programme is that the participants achieve economic self-sufficiency. The economic sanctions are shaped in order to further participation of spouses as well as single parents.

The Norwegian immigration context is one of fairly recent immigration. Between 1980 and 2014, the immigrant population in Norway increased from 2.4 per cent to 12 per cent of the total population. ${ }^{2}$ In a comparative perspective, the Nordic welfare model is characterised by its high employment levels both among men and women, and by being service intensive. Immigrants, particularly of Asian and African origin, have employment levels well below those of the majority of the population. Among all refugees living in Norway in 2012, men had an employment rate of 54 per cent and women 45.6 per cent, compared to 71.6 and 65.7 per cent respectively for the total population of Norway (Olsen, 2014). The employment gap is particularly wide in the first years after arrival, but refugees continue to lag behind after several years.

The challenges of integrating migrants into the Norwegian labour market and society differ significantly according to the migrant's reasons for migration, formal skills and country of origin (Official Norwegian Report, 2011: 7). Participants in the NIP are refugees and many lack formal skills relevant to 
the Norwegian labour market. Many also come from societies characterised by traditional gender roles, something that in many cases adds to the problem (Djuve et al., 2011). When Norway introduced the NIP for newly arrived refugees and their families in $2004,{ }^{3}$ the aim was to give each participant basic skills in the Norwegian language, basic insight into Norwegian society and to prepare him or her for employment or education. The law was also clear in its gender egalitarian ambitions, emphasising that 'gender equality and the individual's responsibility for their own provision by means of paid employment has gradually become a central feature of Norwegian society', and that the programme should not be implemented in a way that would support any traditional gender roles (Proposition to the Odelsting nr.28, 2002-03: 68).

The Introductory act entitled newcomers to an individually tailored training plan as well as a modest fixed income (approximately €21,00o EUR annually). This benefit is not means-tested, meaning that work on the side is possible without affecting payments. Every adult member of the household is entitled to the introductory benefit, as long as they participate full-time and according to their individual plan. This individual benefit had a double purpose: to reduce the risk of clientification by providing a direct link between active participation and payments and to promote full-time activation and, later on, employment among women. Parents with young children are offered subsidised childcare and special consideration is given to participants with health problems. The benefits are, however, conditional upon participation in a full-time (30-37.5 hours a week) qualification programme lasting up to two years (three years in special cases). Illegitimate absences from the set activities are deducted from the benefits, hour by hour.

By conditioning financial support on participation, extensive language and work training became compulsory for most newly arrived refugees and their families - an entire social category comprising highly diverse individuals. Every year, somewhere between 8,000 and 13,000 refugees are registered as participants in the NIP. ${ }^{4}$ There is no 'cherry picking' of candidates, as the programme is meant to be flexible enough to include everyone, regardless of education level, prior work experience or care responsibilities. As the content of the programme is not specified in much detail in the Introductory act, there is room for local adaptations. Adding to the 'staple' components of language training, social studies and work-oriented activities, municipalities have come up with an array of other courses. These additional courses are necessary in order to meet the requirements for full-time, individually adapted programmes and range from carpentry training and cooking classes to computer courses. There is also a wide range of other activities, such as helping children with homework, participating in psychiatric treatment or doing physical exercise (Kavli et al., 2007).

The Introductory Act (§6.3) (Ministry of Children, Equality and Social Inclusion, 2003) states that the programme should be based on an individual 
plan and that this plan is to be drafted 'in cooperation with the participant'. For successful cooperation, the participant needs to receive information so that he or she is able to make informed choices. The law and its regulations illustrate the expectation of both agency among programme participants and the service providers' facilitation of this agency. At the same time, the legal framework makes it clear that, if the participant disagrees with the municipality, the municipality has the last word. In other words, there is a limit to the influence users can have over their individual plan. The challenge for the service provider is to define and implement this limit.

\section{Data and methods}

The NIP was evaluated in 2007 and in 2011 and our data primarily stem from having undertaken these evaluations. ${ }^{5}$ The data comprise both quantitative and qualitative interviews, but the main emphasis in this article is on the qualitative data. All the individual interviews were semi-structured in order to make room for the respondents' own perspectives as well some key questions and topics.

\section{Individual interviews and focus groups with fifty-four NIP caseworkers and thirty-seven language teachers in the NIP programmes}

The researchers spent one or two days in each of the seventeen municipalities included in the qualitative part of the two studies. This enabled interviews to be combined with visits to the local training and counselling facilities. Focus groups (90-120 minutes) with three to four participants were conducted with both caseworkers and teachers. This gave the advantage of collegial reflection and added a dynamic to the discussions that the researchers as outsiders would otherwise have had difficulty facilitating. Individual interviews (60-90 minutes) provided a more confidential setting and enabled topics that were potentially more sensitive to be addressed, such as (non-)compliance with rules and regulations or assessments of the different actors in the NIP. The survey indicates that there is a majority of women among NIP service providers and this is reflected in our qualitative sample.

\section{Individual interviews with thirty-five NIP participants}

It is the local service providers - teachers and case workers - who are at the centre of our analysis. But to balance and broaden our understanding of how different types of service providers respond and relate to different types of service users, we included interpreter-assisted interviews with immigrants who were, or had been, NIP participants $(2010,2011){ }^{6}$ The interviews were semistructured and lasted between thirty and eighty minutes, mainly covering how the informant had experienced the different aspects of the NIP, what influence they were able to have in the drafting of their plan and what was important to 
them in their lives in Norway. The invitation to participate was mainly conveyed by NIP employees, who followed, as far as possible, our list of requirements regarding age, gender, country of origin, education, family status and work experience prior to settlement. We were conscious that this approach could make participation in our study seem obligatory and make the participants wary of criticising the programme. To make clear that their anonymity would be preserved, all information was repeated before the interview commenced and they were asked once more if they would like to participate. There is a majority of women among the informants. The data are therefore particularly valuable for illuminating challenges female participants might encounter in a work-oriented, full-time activation programme.

\section{Survey of 329 NIP caseworkers in a representative sample of Norwegian municipalities}

Invitations to participate were sent to the 256 municipalities that had accepted refugees for settlement in the three years prior to the survey. In each of the 220 municipalities that responded, up to four caseworkers were invited to answer questions concerning their everyday implementation of the programme, including several open-ended questions. The topics included factual questions about the implementation of the NIP, but also questions relating to more normative topics concerning the delimitation of service providers' and service users' responsibilities. The response rate was high -84 per cent. As most Norwegian municipalities are small and settle refugees in limited numbers, ${ }^{7}$ very few employed more than four caseworkers within the programme. Even so, we are aware that our sample of caseworkers is not entirely representative for the total population of caseworkers due to a systematic oversampling of caseworkers in smaller organisations.

\section{Carers and Clerks}

The 'Carer' and the 'Clerk' are analytical categories. Most service providers are a mix of the two that most likely will vary over time and according to the situation. But to provide the reader with some idea about the distribution of rule-orientation and care-orientation, we will analyse a few relevant dimensions included in our survey of NIP caseworkers.

The data from the web-survey allow us to divide the 329 caseworkers into categories of predominantly Carers or predominantly Clerks. The categorisation can be done in various ways. We have chosen a quite simple approach by using the answers to the statement: 'I often help participants with issues that lie outside the framework of the programme.' By defining those who answer that this statement 'fits very well' as predominantly Carers and the others as predominantly Clerks, we split the sample into two equal halves. By analysing how these categories 
respond to other statements that relate to the 'Carer' and 'Clerk' definitions, such as the inclination to interpret regulations flexibly and working more than office hours in order to serve clients, we find some coherence in the dimensions. The Carers are more inclined to interpret regulations flexibly than the Clerks ( 58 per cent versus 40 per cent) and to work more than office hours to assist their clients (53 per cent versus 35 per cent). ${ }^{8}$ However, there is also a considerable proportion of Clerks (by this categorisation) who interpret rules flexibly and put in extra office hours. This underscores that the caseworkers can be a mix of both types. There is also a strong association between this categorisation of 'Carers' and 'Clerks' and the caseworkers' strategies towards 'bad agency': as many as 70 per cent of the 'Carers', by this definition, state that they sometimes let users' perspectives prevail even if they disagree with these perspectives, in contrast to 49 per cent of the 'Clerks' $(p<p 0.01)$. In other words, it is quite common for caseworkers to show some leniency in cases of 'bad agency', but more so for 'Carers' than for 'Clerks'.

In the next two sections, we will return to the qualitative data to study in more detail the caseworkers' understandings of, and strategies for, user influence when faced with different categories of users - the Pawns and the Disagreeing Queens. The categorisations of service users and service providers in the following sections are qualitative and not based on the quantitative survey presented in this section.

\section{From Pawn to Queen}

Service providers in the NIP face service users from all levels of educational backgrounds (including no education at all), family structures, work experiences and health issues. Service users' ability to engage in planning activities within the programme will naturally vary. Most service providers agree that user influence involves people having a say in matters that concern them. To ask, to take time to listen and to educate are commonly mentioned both by caseworkers and teachers within the NIP when we ask them to define and elaborate on the concept of user influence.

The time and learning aspect of user influence described by service providers was also addressed by service users. One of the participants we interviewed was a mother of three from Somalia in her early thirties. At the time of our interview, she had lived in Norway for four years. The NIP only lasts for two or a maximum of three years, but she was still in the programme at the time of our visit due to two periods of maternity leave after her arrival in Norway. ${ }^{9}$ We asked her if her caseworker had enquired about her wishes and aims. She responded:

Participant 1: I wasn't sure what I could do when I first came here. Only that I wanted to work. Perhaps something with children ... or cooking. We (referring to her caseworker) talked about different jobs you can have in Norway and 'Tom' said I should talk to people I knew who had been here a while and then think with my heart. He said it that way - think with your heart. I 
did, and decided that I wanted to try to qualify to work in a nursing home. But if that doesn't work out a childcare centre is also ok. I can do many things ... I think.

Her story is similar to many of the stories we heard when we posed this question to NIP participants. A feeling of uncertainty at first, but, given some time to think as well as information about alternatives and practical experiences, participants gain a growing sense of available possibilities.

Other participants have clear goals but are less confident about how to reach them. Some express annoyance over the expectation that they should be involved in the drafting of the plan. An Afghan man, aged twenty-four, had enrolled in the NIP one and a half years prior to our interview. He wants to become a car mechanic, but offered no opinions as to what sort of training he would prefer in order to reach his goal. He said:

Participant 2: I didn't go to school in Afghanistan, so I don't know ... )] I do not know the rules in Norway, or what it is like here. I trust that they (referring to the teachers and his caseworker) know best.

The NIP has an ambition to empower programme participants, and user influence is mentioned as a way to accomplish this. But programme participants are not necessarily interested in getting involved in putting together a qualification plan, even though they may have concrete plans for the outcomes of programme participation. A similar point is made by Boehm and Staples (2002), who found that service users and service providers have different views on what empowerment entails. While service providers put emphasis on process, the most important aspect for service users was concrete outcomes: better housing, employment, income etc.

Both the care- and the rule-oriented service providers are aware of the challenges of furthering user influence when the users do not express their preferences. Still, they tend to respond differently when they face participants who either offer no opinions on programme targets or do have goals but leave it up to the caseworker to decide on how best to reach them. Two service providers, both with many years of experience, gave contrasting accounts of how they approach participants who struggle to relate to the choices they are asked to make within the programme framework:

Carer: Well, my definition of user influence is that they (the participants) always have the last word. My job is to supply information, but also to offer counsel. But it is they who must make the choices.

Clerk: You need to formulate your expectations about them getting involved in the choices they have to make about their future ... And still, you sometimes have to decide for them - their process can take too long.

Typically, both the Carer and the Clerk will allow the participant to consider different alternatives during the first months when they are busy mainly with 
language classes. Then, the Clerk tends to decide on a plan on behalf of the participant. The Carer will be inclined to postpone the decision and focus her efforts on educating the participant to form and to articulate his/her opinions. In some cases, this strategy will gradually give the 'Pawn' more of a voice and move them toward becoming a 'Queen'. This will be a high priority for the 'Carer' and in their mind make the participant more skilled to take on new challenges even if the programme is completed without (for example) work training. For the 'Clerk', complying with programme requirements will have a higher priority. They will tend to decide on behalf of the participant rather than wait. The 'Clerk' will also be inclined to argue that there is little point in waiting too long for the participant to form an opinion, and that it is the final result more than the process that is important.

\section{Disagreeing Queens}

Both caseworkers and participants tell stories about disagreement, naturally more related to Queens than Pawns. Negotiations over such disagreements are a central element of user involvement, and the aim of the service provider must be to reach an agreement on key issues such as ambitions and programme components. Often this is achieved, but negotiations do not always yield agreement. An important question then is whether such unresolved disagreements leave room for user influence at all.

A topic that often comes up concerns programme content-language classes, work training or both? One participant described how she perceived her situation as inflexible. She said:

Participant 3: Mostly, the thing we disagreed about was the work training. I learned more at school and wanted to combine work and Norwegian language classes, three days' work and two days of school, but they said no.

Interviewer: Did you try to persuade them?

Participant 3: No ... You just can't. It is not you who decides. It doesn't help to discuss or present new arguments. They say "You have to". "There's nothing more to discuss" they say ... So no, I did not try to argue or debate.

In this case, the participant's wishes were overruled and her continuing disapproval might have gone undetected by her caseworker as she no longer saw any point in arguing her case. On the other hand, we also find examples of participants who feel that their opinions have been taken seriously and that service providers sometimes change their minds. A Somali woman approaching the end of her programme responded to our inquiries about her influence on the programme content this way:

Participant 4: You just need to say what you want and what you don't want. He (referring to her caseworker) hasn't sent me on work training and if you don't want to do work training you just tell them that. You can say no. 
In her case, it is fair to say that she still had a long way to go before regular employment was a realistic option. She was in poor health and had no prior school or work experience. Her caseworker might have felt there would be little to gain by forcing her to participate in work-related activities. Nevertheless, how service providers handle participants with a clear, voiced agency varies. In this particular case, participant 4 voiced her opinion and, as far as our data show, her caseworker gave in, in respect that he did not comply with the programme's demand of including work training within the programme period.

In our survey of NIP caseworkers, close to 60 per cent confirmed that they sometimes let the participant's view affect programme decisions, even if they disagreed with the participant's view. But why do service providers sometimes give in to the wishes or demands of service users even if they believe that, by doing so, the programme becomes less effective? According to our model, the Clerks will rely mostly on the overall target of employment and what NIP regulations state about the role of work training to guide their decisions. They are less likely to be found in the group of caseworkers who sometimes give in to the wishes of participants contrary to their better judgements. The Clerk will overrule the judgements of a Disagreeing Queen. In contrast, Carers tend to regard the participant's own motivation and plans as essential for success, even if it entails fewer programme hours and no work training at all. Reflections from two experienced service providers, can serve as examples of each type of bureaucratic response:

Carer: Sometimes I give in to wishes that will give them a less effective programme. But still, when you manage to argue and quarrel yourself out of work training and into a third year of language classes because you feel safer that way, you have to agree that that is user influence and a good thing.

Clerk: Many participants have overly ambitious plans that cannot be met within the programme. They need to be informed of the realities ... sometimes we have to take people out of the programme. But for the most part, I tell them how it has to be. Then we might fall out for a while, but it usually sorts itself out in the end.

We also find cases where a transition from 'bad agency' to 'good agency' is achieved through a redefinition by the service provider of what 'good agency' is, often related to the overall goal of the activation programme. This is an adaptation typically made by Carers and involves not only bending, but even breaking, the regulations of the NIP. The examples we have encountered all relate to the situation for mothers. The NIP participants often emphasise that to take care of children after settling in a country that is very different from where you grew up, and often without support from family and friends, is time-consuming. This constitutes a dilemma for service providers who see the mothers' challenges in their everyday life, but at the same time are responsible for the implementation 
of a full-time programme with employment and economic self-sufficiency as its main goal.

Carer: I think that we ask too much too fast from some of these women. They have so many responsibilities at home and are so tired ... If she can be a good mother and take care of her children, I think that is a good result.

Clerk: I think there is a lot of tradition here - that they (women) should stay home, cook, and care for children. It is important not to 'understand' too much. Combining employment and children is a struggle for all of us ... They need to learn to hurry.

Clerks can also struggle with ambivalence when confronted with participants who have time-consuming care responsibilities. But, compared to the Carers, they are less inclined to condone a less intensive (not full-time) and less employmentrelated (no work training) plan for mothers. Their argument is usually that the strict activation line is for the best in the long run, both economically and with regard to gender equality. Carers, on the other hand, often question the overall target of paid employment for women with little education, no prior work experience and large care responsibilities, and resent what they perceive as the central government's single focus on employment. In these cases, some of the service providers adjust the programme's intensity and concentrate on programme targets other than paid employment. This is a strategy that, from the outside, resembles 'giving in' to a Disagreeing Queen - with the exception that the service provider does not really disagree. That is, they disagree, but with the policy they are meant to enforce, not with the service user they are meant to enforce it upon.

\section{Discussion, conclusion and suggestions for further research}

In this article, we have examined how user influence is shaped by the characteristics of service providers and service users respectively. Inspired by Le Grand (2003/06), but also by the critique of his model, we have framed the empirical analysis by categorising service providers according to their practices, as either care-oriented (Carers) or rule-oriented (Clerks), and service users according to their agency, as either autonomous (Queens) or passive (Pawns). Both Carers and Clerks find user involvement to be challenging, particularly when users are Pawn-like or display 'bad agency'. Carers and Clerks respond to these challenges differently, with corresponding consequences for the implementation of user influence. When met with Pawn-like users, the Clerk is inclined to decide goals and measures on behalf of the user. When faced with 'bad agency', in other words service users that have preferences that are incompatible with the goals or the methods of the programme, these preferences tend to be overruled. Clerks listen to the users' opinions, but do not engage in negotiations over what they perceive to be the overall aim of the programme. The Clerk emphasises being on 


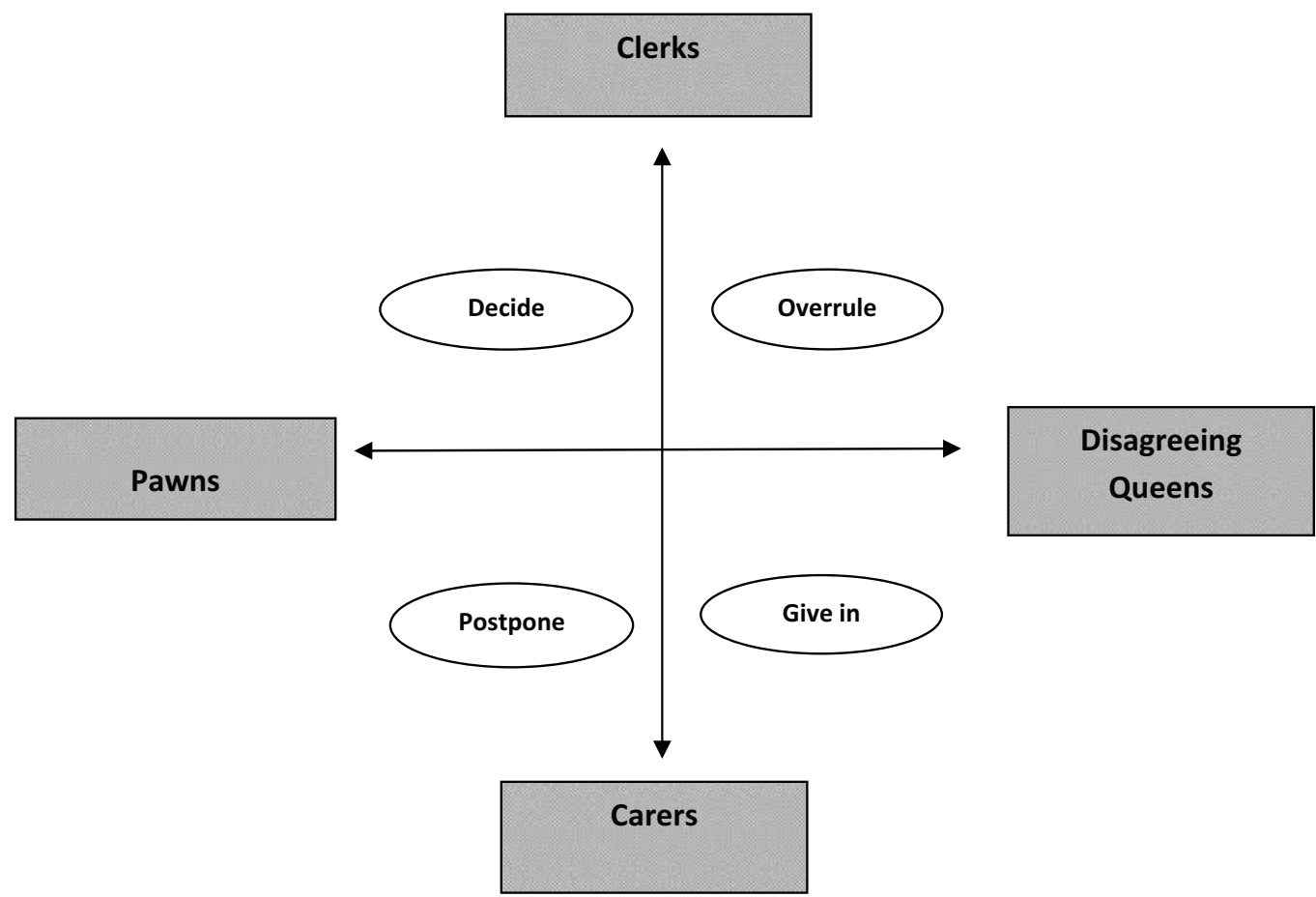

Figure 2. Interaction outputs, by axes of service-provider approach and service-user agency

friendly terms with the users but maintains a professional distance in relation to topics and tasks that she perceives to belong to the private sphere - their own, as well as the user's.

The Carer on the other hand typically shows pronounced reluctance to overrule the choices made by the service user. This is rooted in a substantially different understanding of user influence compared to that of the Clerk. The Carer sees the process of involvement as empowering, educational and necessary in order to reach long-term goals of economic and social inclusion in society. In this respect, the Carer relates closely to what Dean (2003b) has described as activation of the human capital type. In order to achieve user involvement, the Carer is prepared to wait - sometimes for a very long time - before they draft a plan or demand that the user participates in programme activities that he or she is not motivated to do. In this and other respects, the Carer is also inclined to stretch the rules to comply with the wishes of the service user, based on her general belief that user influence is highly educational for the participants, and essential for their inclusion in society.

To balance user influence with policy ambitions of rapid economic and social integration of immigrants can be a challenging task for service providers. Both Pawns and Disagreeing Queens can put the service providers to the test, although in different ways. We have illustrated the different strategies service providers apply to cope with these challenges in Figure 2.

When Carers are confronted with Pawns, they tend to postpone decisions and wait until the service user expresses stronger agency. When met with Disagreeing 
Queens, they are inclined to give in to the wishes of the service user, even though they might not think the goals and measures the service user suggests are the best ones. The Clerks on the other hand, tend to decide on behalf of the Pawns, and to overrule wishes from Disagreeing Queens. Strictly speaking, only one of these strategies actually entails user influence: when Carers give in to Disagreeing Queens. If the service provider has a good reason for disagreeing, this is not a very good outcome. All four outcomes are rather examples of failed implementation of user influence - so far. They may, however, be part of a long-term ambition to turn Pawns into Queens, and 'bad agency' into 'good agency'.

The findings also invite a somewhat broader discussion of the ambivalence service providers experience in trying to balance the programme's goal of employment with how the participants perceive their present and envisage their future. Hagelund (2005) has described how street-level bureaucrats sometimes struggle with their impulses to 'be kind' to service users, because this in the long run can turn out to be 'bad' in terms of integration. She interprets this within a broader discourse of integration crises that emerged in Norway in the late 1990s, where 'kindness' was seen as source of 'clientification'. The NIP was introduced in part as an answer to the critique and close to 90 per cent of the local service providers believe that the NIP has improved the introduction of newcomers into Norwegian society (Kavli et al., 2007). Even so, implementing activation policy measures of economic sanctions towards participants who are already economically marginalised, provide for children and/or do not share Norwegian gender equality values, clashes with the values and professional ethics of many caseworkers. In particular, the Carers are inclined to give in to 'Disagreeing Queens' when caring responsibilities and motherhood are brought to the table. In this way, the service providers' understanding of 'good agency' is flexible - sometimes far beyond the regulations of the programme. Women can receive plans that are endorsed by their caseworkers without fulfilling the legal programme requirements. These 'rule-bendings' may also come about as a result of the service provider's assumptions about what a female Pawn 'probably' prefers.

It should be remembered that user influence is not the main ambition of the NIP. Efforts to achieve user influence must be balanced against the overall goal of transition to employment or education. When faced with Pawn-like users or Disagreeing Queens, it is not self-evident which of the service providers' practices illustrated in Figure 2 will result in optimal introductory programmes. The problem with postponing is that it may take (too) long to put together a good plan. Deciding on behalf of the participant is obviously not complying with the ambitions of user influence, but may generate a more rapid programme progression. From an empowerment perspective, it may be as important to draft efficient plans that lead to employment and good language skills as to involve the participants in decisions about the composition of the plan. Small (2000) claims 
that focusing on choices may in fact disempower service users, because many lack sufficient knowledge about alternatives and consequences.

Choosing when to overrule and when to give in is an essential part of caseworker discretion. This choice must be made in each separate case, balancing the need for good quality with the potential empowering effects of real user influence. Then again, the time and resources necessary to provide a good quality programme are not always available to the caseworkers (Brodkin, 1997; Lipsky, 1980) who are sometimes left to implement a programme that they, in the words of one of our service provider informants, 'are not very proud of. This might reduce the motivation to overrule Disagreeing Queens, and produce leniency with regard to what should be defined as 'Good' or 'Bad' agency.

Turning Pawns into Queens seems to be a prerequisite for user influence. So far, little is known about the consequences of different approaches among service providers for this process. Similarly, there is still little knowledge about the actual empowering consequences of different modes of interaction between service providers and service users. We consider these to be important issues for further research.

\section{Notes}

1 User involvement is here defined as any communication of individual characteristics, needs or preferences relevant to the shaping of the relevant service, from the user to the service provider. User influence implies that user preferences have had an actual influence on the shaping of the service.

2 Immigrants are defined as persons born abroad of two foreign-born parents and four foreignborn grandparents (Statistics Norway 2014).

3 The target group comprises people between eighteen and fifty-five years of age who need basic qualifications and who have been granted asylum or residence on humanitarian grounds, are resettlement refugees or family immigrants with the groups mentioned above. Persons who, after the breakup of a relationship, have been granted a residence permit on an independent basis due to abuse in the relationship, have been included since 1 July 2011 (Ministry of Children, Equality and Social Inclusion 2003).

4 Numbers according to the Norwegian Directorate of Integration and Diversity 2013.

5 Kavli et al. (2007), Djuve et al. (2011).

6 Three informants were recruited through Norwegian language classes (Sandbæk, 2011) and one through a network-recruitment of single immigrant mothers (Kavli, Nilsen and Sandbæk, 2010).

7 In the three years prior to the study in question, 288 municipalities received refugees for settlement. During these three years, 27 per cent of the municipalities received ten refugees or less, 24 per cent received eleven to twenty refugees, 25 per cent received twenty-six to fifty refugees and 25 per cent received fifty-one refugees or more (numbers supplied by the Norwegian directorate of Integration and Diversity, published in Kavli et al., 2007).

$8 \mathrm{p}<0.01$ for the difference between Carers and Clerks.

9 Participants in the NIP are entitled to ten months maternity leave. During maternity leave, the introductory benefit is stopped, but participants on leave can apply for social assistance. 


\section{References}

Arnstein, S. R. (1969), 'A ladder of citizen participation',Journal of the American Institute of Planners, 35: 4, 216-224.

Bloom, H., Hill, C. and Riccio, J. (2003), 'Linking program implementation and effectiveness: lessons from a pooled sample of welfare-to-work experiments', Journal of Policy Analysis and Management, 22: 4, 551-575.

Boehm, A. and Staples, L. H. (2002), 'The functions of the social worker in empowering: the voices of consumers and professionals', Social Work, 47: 449-460.

Brochmann, G. and Djuve, A. B. (2013), 'Multiculturalism or assimilation? The Norwegian welfare state approach', in Peter Kivisto and Östen Wahlbeck (eds.), Debating Multiculturalism in the Nordic Welfare States, Basingstoke: Palgrave Macmillan.

Brodkin, E. Z. (1997), 'Inside the welfare contract: discretion and accountability in state welfare administration', Social Service Review, 71: 1, 1-33.

Dean, H. (2003a), 'The third way and social welfare: the myth of post-emotionalism', Social Policy and Administration, 7: 695-708.

Dean, H. (2003b), 'Re-conceptualising welfare-to-work for people with multiple problems and needs', Journal of Social Policy, 32: 3, 441-459.

Dean, H. (2007), 'The ethics of welfare-to-work', Policy and Politics, 35: 4, 573-590.

Djuve, A. B. (2010), 'Empowerment or intrusion? The input and output legitimacy of introductory programmes for recent immigrants', Journal of International Migration and Integration, 11: 4, 403-422.

Djuve, A. B. (2011), 'Introductory programmes for immigrants: liberalism revisited, or changing ideas of citizenship?', Nordic Journal of Migration Research, 1: 3, 113-125.

Djuve, A. B. and Kavli, H. C. (2006), 'Velferdsstatens skreddere: Skjønn og brukermedvirkning i flyktningetjenesten', Tidsskrift for velferdsforskning 2006/4.

Djuve, A. B., Kavli, H. C. and Hagelund, A. (2011), Kvinner i kvalifisering: Introduksjonsprogram for nyankomne flyktninger med liten utdanning og store omsorgsoppgaver, Fafo-rapport 2011: 02.

Duncan, S. and Edwards, R. (1999), Lone Parents, Paid Work and Gendered Moral Rationalities, Basingstoke: Palgrave Macmillan.

Eriksen, E. O. (2001), Demokratiets sorte hull: Om spenningen mellom fag og politikk, Oslo: Abstrakt forlag.

Hasenfeld, Y. (1999), 'Social services and welfare-to-work: prospects for the social work profession', Administration in Social Work, 23: 3, 185-199.

Hagelund, A. (2005), 'Why it is bad to be kind: educating refugees to a life in the welfare states a case study from Norway', Social Policy and Administration, 39: 6, 669-683.

Jensen, P. H. and Pfau-Effinger, B. (2005), 'Active citizenship: the new face of welfare', in A. Andersen, M. Guilllemard, P. H. Jensen and B. Pfau-Effinger (eds.), The Changing Face of Welfare, Bristol: The Policy Press.

Jewell, C. (2007), Agents of the Welfare State: How Caseworkers Respond to Need in the United States, Germany and Sweden, New York: Palgrave Macmillan.

Jordan, B., Stråth, B. and Triandafyllidou, A. (2003), 'Comparing cultures of discretion', Journal of Ethnic and Migration Studies, 29: 2, 373-395.

Kavli, H. C., Nielsen, R. A. and Sandbæk, M. L. (2010), 'HYPERLINK "http://www.fafo.no/ pub/rapp/20176/index.html” Stønadsordningen for enslige forsørgere’, Hvordan fungerer den for mottakere med innvandringsbakgrunn? Fafo-report 2010: 32.

Kavli, H. C., Hagelund, A. and Bråthen, M. (2007), Med rett til å loere og plikt til å delta: En evaluering av introduksjonsordningen for nyankomne flyktninger og innvandrere, Faforapport 2007: 34

Le Grand, J. (2003/2006), Motivation, Agency and Public Policy: Of Knights and Knaves, Pawns and Queens, Oxford: Oxford University Press.

Lipsky, M. (1980), Street-Level Bureaucracy: Dilemmas of the Individual in Public Services, New York: Russell Sage Foundation. 
Loyens, K. and Maesschalck, J. (2010), 'Toward a theoretical framework for ethical decision making of street-level bureaucracy: existing models reconsidered', Administration and Society, 42: I, 66-100.

Marston, G., Larsen, J. and McDonald, C. (2005), 'The active subjects of welfare reform: a street-level comparison of employment services in Australia and Denmark', Social Work and Society, 3: 2, 141-158.

May, P. and Winter, S. (2007), 'Politicians, managers, and street-level bureaucrats: influences on policy implementation', Journal of Public Administration Research and Theory, 19: 3, 453-476.

Minas, R. (2009), Activation in Integrated Services? Bridging Social and Employment Services in European Countries, Working paper 2009:11, Stockholm: Institute for Future Studies.

Ministry of Children, Equality and Social Inclusion (2003), The Introduction Act 2003 (LOV-2003-07-04-80), The Act on an Introduction Programme and Norwegian Language Training for Newly Arrived Immigrants, http://www.ub.uio.no/ujur/ ulovdata/lov-20030704-080-eng.pdf.

Official Norwegian Report 2011: 7 (NOU), Welfare and Migration: The Future of the Nordic Model, Report submitted to the Ministry of Children, Equality and Social Inclusion, http://www.regjeringen.no/pages/16413697/nou_2011_7_perspective_andsummary.pdf

Olsen, B. (2014), 'Flyktninger og arbeidsmarkedet, 4 kvartal 2012', Rapporter 2014/6, Oslo: Statistics Norway.

Proposition to the Odelsting nr.28 (2002-2003), Om lov om introduksjonsordning for nyankomne innvandrere (introduksjonsloven), http://www.regjeringen.no/en/dep/ asd/doc/regpubl/otprp/20022003/otprp-nr-28-2002-2003-.html?id=171771.

Sandbæk, M. L. (2011), 'Voksne innvandrere i Norskopplæringen: Brukerundersøkelser i Basis og Helsefagarbeideropplæringen', Fafo-notat 2011:03, Oslo: Fafo.

Sainsbury, R. (2008), 'Administrative justice, discretion and the "welfare to work" project', Journal of Social Welfare and Family Law, 30: 4, 323-328.

Small, N. (2000), 'The changing National Health Service: user involvement and palliative care', in N. Small and P. Rhodes (eds.), Too Ill to Talk: User Involvement in Palliative Care, London: Routledge.

Statistics Norway (2014), Innvandrere og norskfødte med innvandrerforeldre, 1 January 2014, Publisert: 24 April 2014

Taylor-Gooby, P. (2005), 'Ideas and policy change', in P. Taylor-Gooby (ed.), Ideas and Welfare State Reform in Europe, Basingstoke: Palgrave Macmillan.

Terum, L. I. (2003), Portvakt $i$ velferdsstaten: Om skjønn og beslutninger i sosialt arbeid, Oslo: Kommuneforlaget.

Van Berkel, R. (2007), 'Individualized activation in the EU', in R. Van Berkel and B. Valkenburg (eds.), Making It Personal, Bristol: The Policy Press.

Van Berkel, R. and Van der Aa, P. (2012), 'Activation work: policy programme administration or professional service provision?', Journal of Social Policy, 41: 4, 493-510.

Van Meter, D. and Van Horn, C. E. (1975), 'The policy implementation process: a conceptual framework', Administration and Society, 6: 4, 445-488.

Weber, M. (1920/1978), Economy and Society, Berkeley, CA: University of California Press.

Wright, S. (2012), 'Welfare-to-work, agency and personal responsibility', Journal of Social Policy, 41: 2, 309-328. 